U.S. Department of Commerce

Technology Administration

National Institute of Standards and Technology
Office of Applied Economics

Building and Fire Research Laboratory

Gaithersburg, MD 20899

\title{
Measuring and Assessing the Consequences of Technology and Innovation for Affordability of Housing: Proceedings of the NIST - PATH Workshop
}

William I. Whiddon, David B. Hattis, and Chi J. Leng

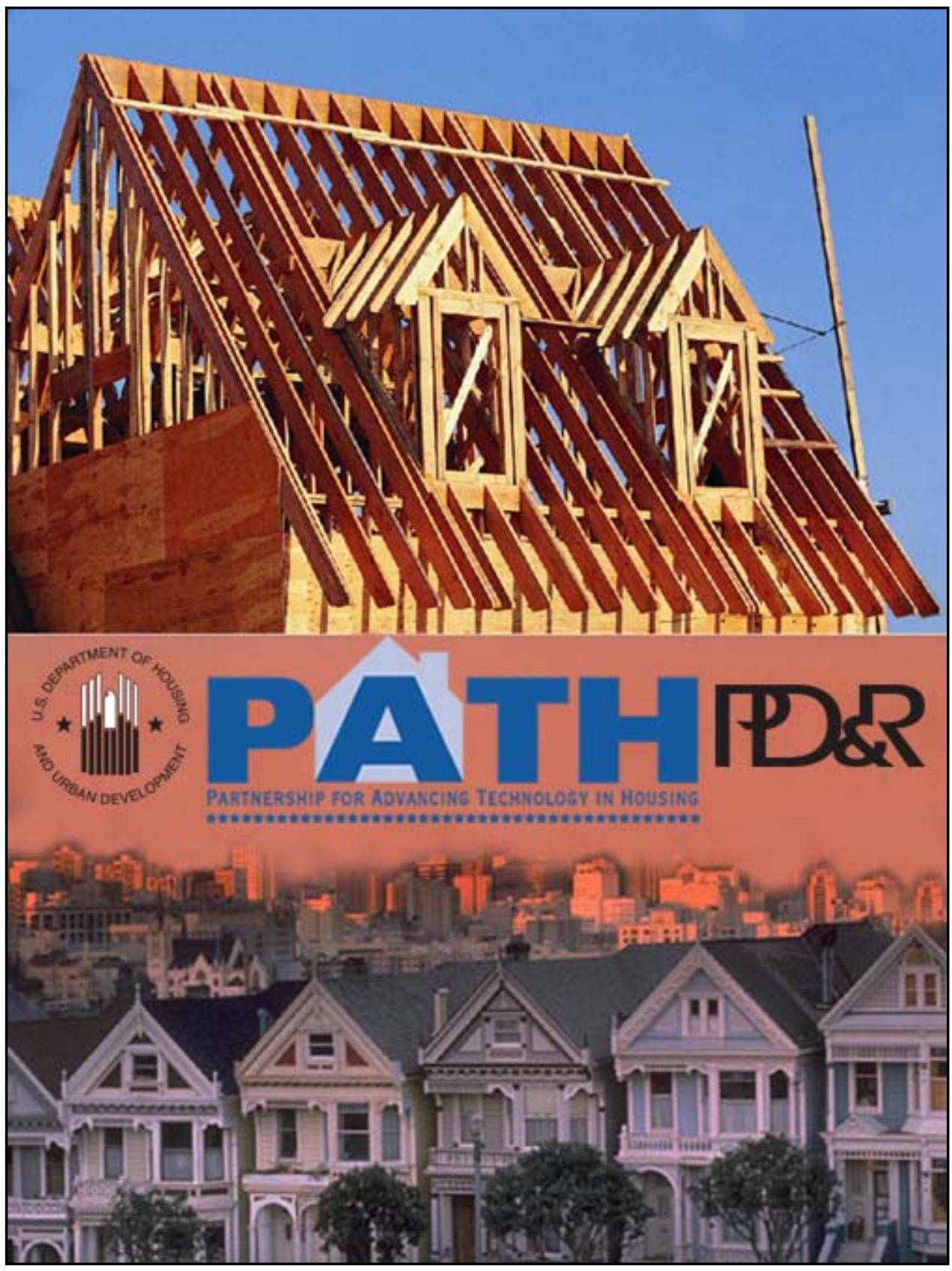





\section{Measuring and Assessing the Consequences of Technology and Innovation for Affordability of Housing: Proceedings of the NIST - PATH Workshop}

William I. Whiddon and David B. Hattis

Building Technology Incorporated

Silver Spring, MD 20910

and

Chi J. Leng

Office of Applied Economics

Building and Fire Research Laboratory

National Institute of Standards and Technology

Sponsored by:

U.S. Department of Housing and Urban Development

Office of Policy Development and Research

Washington, DC 20410

February 2004

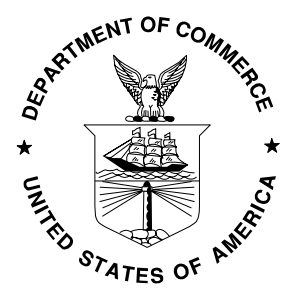

U.S. DEPARTMENT OF COMMERCE

Donald L. Evans, Secretary

TECHNOLOGY ADMINISTRATION

Philip J. Bond, Under Secretary for Technology

NATIONAL INSTITUTE OF STANDARDS AND TECHNOLOGY

Arden L. Bement, Jr., Director 


\section{Foreword}

The Office of Applied Economics (OAE) in the Building and Fire Research Laboratory (BFRL) at the National Institute of Standards and Technology (NIST), through the support of the Partnership for Advancing Technology in Housing (PATH), a program of the U.S. Department of Housing and Urban Development (HUD), is developing a set of affordability guidelines for owner-occupied housing. This report describes the NISTPATH Housing Affordability Workshop held at the NIST Gaithersburg, MD campus on June 4-5, 2003. The purpose of the workshop was to discuss ways for measuring and assessing the consequences of technology and innovation on the affordability of housing.

Affordability has always been an important consideration in housing, but its impact on housing choice has usually been informal. Housing industry stakeholders are realizing the need to address affordability both explicitly and formally. There is no standard, uniform, or accepted definition of affordability, however, that housing industry stakeholders can use to define and measure affordability. Without a set of guidelines for measuring affordability, manufacturers, code officials, homebuilders, mortgage lenders, consumers, and other housing industry stakeholders will not have a clear methodology for evaluating the affordability of alternative or new technologies in housing.

The guidelines currently under development will show how to measure and evaluate the affordability of alternative residential building technologies when compared with a conventionally used technology satisfying the same function or code requirement. The affordability guidelines will help PATH achieve its vision of a $20 \%$ reduction in monthly housing costs by 2010. The affordability guidelines will also support HUD's strategic goal of increasing the availability of decent, safe, and affordable housing in American communities.

The development of the affordability guidelines is a four-step process: (1) producing a white paper highlighting affordability-related issues in owner-occupied housing; (2) convening the NIST-PATH Housing Affordability Workshop and producing this Proceedings; (3) producing a consensus roadmap for developing and deploying the affordability guidelines; and (4) producing a proposed set of affordability guidelines. Shortly after project initiation, OAE entered into a collaborative effort with Building Technology Inc. (BTI). BTI has worked closely with OAE through the completion of the first two steps in the four-step process.

The first step was the production of a white paper. The white paper was used as a background piece by participant stakeholders in the NIST-PATH Housing Affordability Workshop to identify (1) what affordability means to them and (2) what sorts of measurement guidelines and other economic tools would help them. The white paper examined the linkages between affordability and innovation at two scales: (1) the individual materials, products, elements, components, and systems of housing and (2) the entire house and its delivery system. 
The second step was to convene the NIST-PATH Housing Affordability Workshop. The workshop provided a framework for discussing key affordability/innovation-related issues. This report, prepared jointly by BTI and OAE, summarizes the findings and recommendations of that workshop. Prior to the workshop, OAE and BTI developed discussion topics for each of the two scales of innovation and refined them for use by workshop participants. These topics provided the framework for keynote presentations, which served to focus the participants' discussions and to get their views on affordability/ innovation-related issues.

The third step is to develop a consensus roadmap building on the workshop outputs. NIST is exploring ways in which reliance on a carefully selected set of standard practices and input from key housing industry stakeholders can be used to produce a consensus roadmap for developing a set of affordability guidelines. The consensus roadmap will include plans for awareness building and information dissemination. This report contains specific recommendations for a road-mapping exercise as the next step in producing a set of affordability guidelines for owner-occupied housing.

The fourth step is the production of the affordability guidelines. A subsequent technical report will contain a proposed set of affordability guidelines. It will document themes drawn from the white paper, the workshop, and the road-mapping exercise to produce a coherent economic methodology and a proposed set of affordability guidelines based on that methodology. The goal is to deploy a set of affordability guidelines that each key housing industry stakeholder will support.

Robert E. Chapman

Office of Applied Economics

Building and Fire Research Laboratory

National Institute of Standards and Technology

Gaithersburg, MD 20899-8603 


\begin{abstract}
On June 4-5, 2003, the National Institute of Standards and Technology (NIST) and the Partnership for Advancing Technology in Housing (PATH), a program of the U.S. Department of Housing and Urban Development, held a joint workshop with industry at the NIST Gaithersburg, MD campus on key issues affecting housing affordability. The purpose of the workshop was to discuss ways for measuring and assessing the consequences of technology and innovation on the affordability of housing. The workshop was attended by a broad cross-section of the housing industry. Stakeholder groups represented included homeowners, homebuilders, product manufacturers, code officials, financial institutions, and government agencies. Keynote presentations were followed by facilitated discussion for each of the following topics: (1) who benefits from innovation; (2) how to transfer benefits to the home owner; (3) how does each stakeholder view and compute costs; (4) how does each stakeholder view and compute uncertain future benefits; (5) how to evaluate the risks of using innovative technologies; (6) how to measure the social costs and benefits of innovative technologies; (7) how can the regulatory system be used to encourage innovation; and (8) who should bear the costs of new delivery systems for innovative technologies. A final plenary session was held to discuss future directions for applied research. These proceedings contain a synthesis of findings and recommendations for each discussion topic and stakeholder group. Specific recommendations for a road-mapping exercise are included as the next step in producing a set of affordability guidelines for owner-occupied housing. Also included are two appendices that compile findings, recommendations, and observations, organized by discussion topic and stakeholder group.
\end{abstract}

Keywords: Affordability; building codes and standards; building economics; construction; costs; economic analysis; housing; innovation; life-cycle cost; technology 


\section{Preface}

This study was conducted by the Office of Applied Economics in the Building and Fire Research Laboratory (BFRL) at the National Institute of Standards and Technology in collaboration with Building Technology Inc. The study was sponsored by the Partnership for Advancing Technology in Housing (PATH) program at the U.S. Department of Housing and Urban Development (HUD). The overall purpose of the BFRL project, of which this study is a part, is to develop a set of affordability guidelines for owneroccupied housing. These guidelines will help PATH achieve its vision of a $20 \%$ reduction in monthly housing costs by 2010. The affordability guidelines will also support HUD's strategic goal of increasing the availability of decent, safe, and affordable housing in American communities. The intended audience for this document is the public and private sector members of $\mathrm{PATH}$, construction industry representatives, and other interested parties. 


\section{Acknowledgements}

The authors wish to thank all those who contributed so many excellent ideas and suggestions that they have attempted to incorporate into this report. The authors wish to thank Mr. David Engel, Dr. Carlos E. Martín, and Mr. Dana B. Bres of the Office of Policy Development and Research at the U.S. Department of Housing and Urban Development (HUD) for their guidance, suggestions, and support. HUD's Office of Policy Development and Research, in collaboration with the private sector, provides leadership and administrative support to the Partnership for Advancing Technology in Housing (PATH) program. Thanks are also due to Dr. Christopher C. White of the Materials and Construction Research Division at NIST's Building and Fire Research Laboratory (BFRL) for his efforts to coordinate PATH-related research within BFRL and for his comments on the report. Special appreciation is extended to Drs. Harold E. Marshall and Robert E. Chapman of BFRL's Office of Applied Economics for the thoroughness of their reviews and for their many insights and to Mrs. J'aime L. Maynard for her assistance in preparing the manuscript for review and publication. Special thanks are due to each of the Steering Committee members-Mr. David Conover, International Code Council; Mr. Paul Emrath, National Association of Homebuilders; Dr. John R. Hall, National Fire Protection Association; Ms. Michelle K. McDonough, Fannie Mae; Mr. Ron Piester, New York Department of State; Mr. Edgar Sutton, National Association of Homebuilders; Ms. Theresa Weston, DuPont Nonwovens; and Dr. Richard N. Wright-for their guidance in planning and conducting the housing affordability workshop. The report has also benefited from the careful note taking of Ms. Christine A. Izzo and Ms. Jennifer Helgeson of BFRL's Office of Applied Economics during the housing affordability workshop and their reviews and comments on earlier versions of the manuscript. 


\section{Table of Contents}

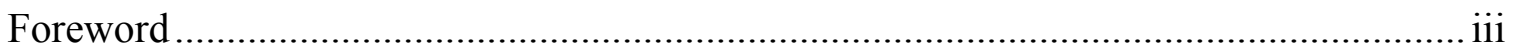

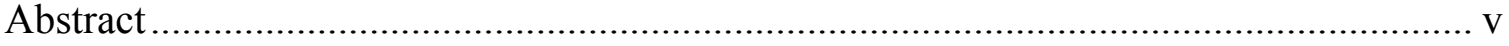

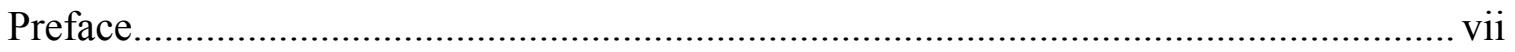

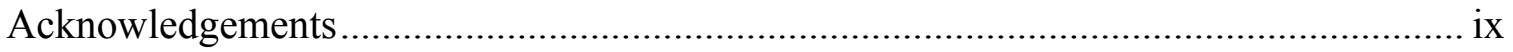

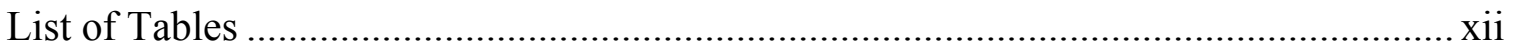

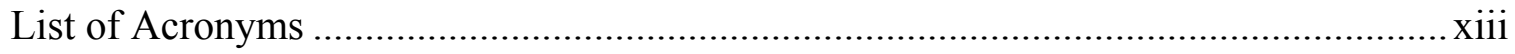

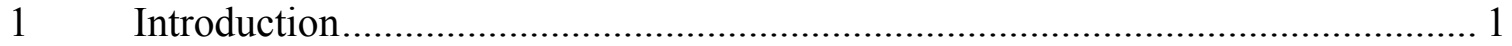

1.1 Background ............................................................................................... 1

1.2 Affordability and Technology: Costs, Benefits, and Incentives ........................... 1

1.2.1 Technology and Innovation at the Scale of Materials, Products, Elements, and Components of Housing .................................................. 2

1.2.2 Technology and Innovation at the Scale of the Entire House and Its Delivery System....................................................................... 2

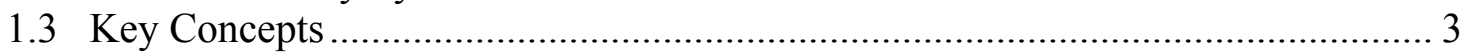

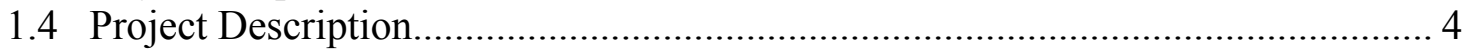

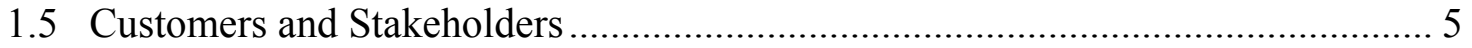

1.6 Workshop Discussion Topics .......................................................................... 5

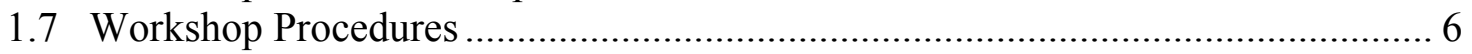

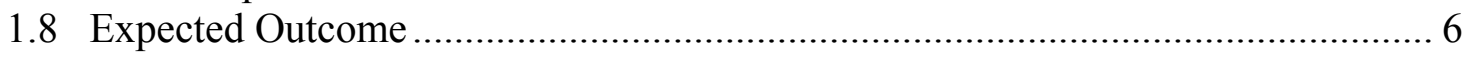

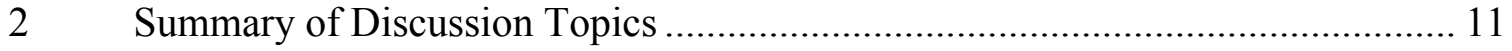

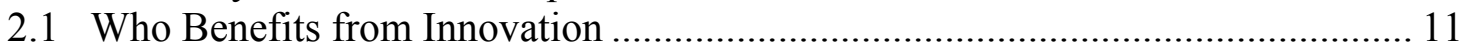

2.2 How to Transfer Benefits to the Homeowner .................................................... 11

2.3 How Does Each Stakeholder View and Compute Costs ................................... 12

2.4 How Does Each Stakeholder View and Compute Uncertain Future Benefits..... 12

2.5 How to Evaluate the Risks of Using Innovative Technologies .......................... 13

2.6 How to Measure the Social Costs and Benefits of Innovative Technologies ....... 14

2.7 How Can the Regulatory System Be Used to Encourage Innovation................... 15

2.8 Who Should Bear the Costs of New Delivery Systems for Innovative

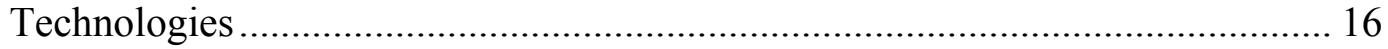

3 Summary of Stakeholder Perspectives.................................................... 17

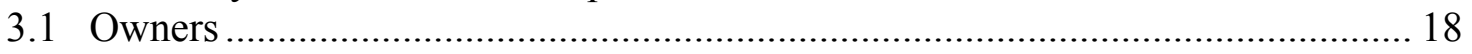

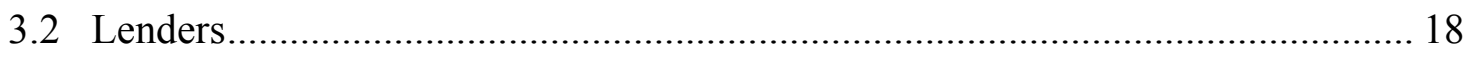

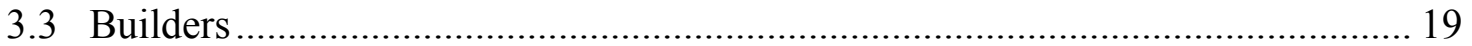

3.4 Building Product Manufacturers ................................................................. 20

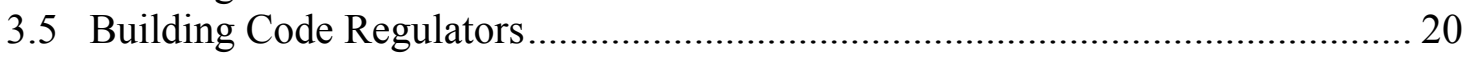

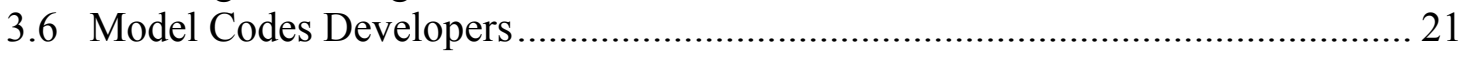




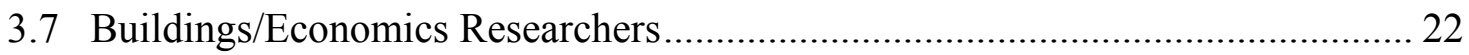

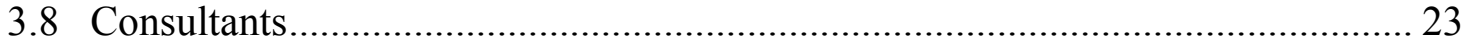

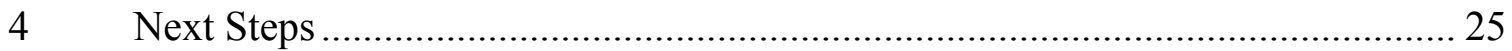

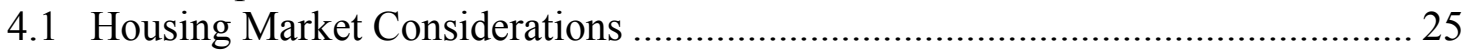

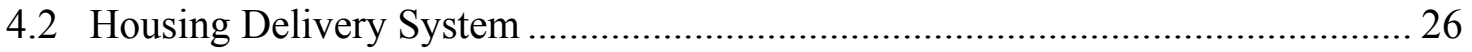

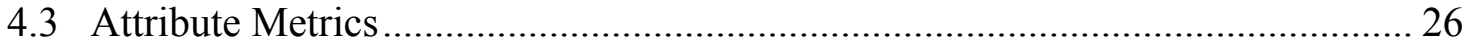

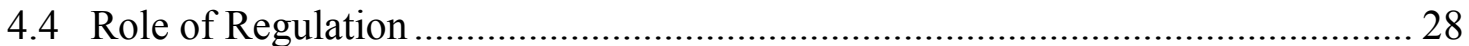

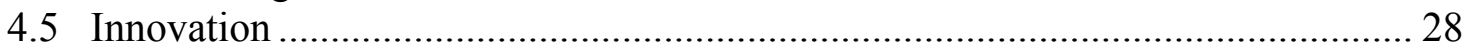

Appendix A Individual Comments Organized by Discussion Topic ........................... 29

Appendix B Individual Comments Organized by Stakeholder Group and Keyword ... 81

Appendix C Schematic Durability Rating System and Valuation ............................. 143

Appendix D Workshop Agenda ……………………....................................... 147

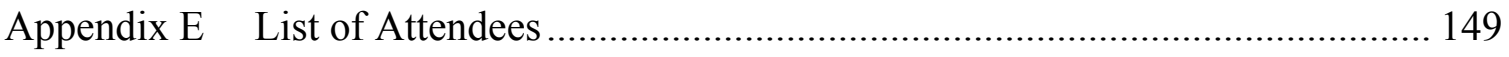

\section{List of Tables}

Table 1-1. Affordability and Technology: Hierarchy of Key Stakeholder Groups...... 7

Table 1-2. Affordability-Related Benefits (or Cost Savings) Classified by

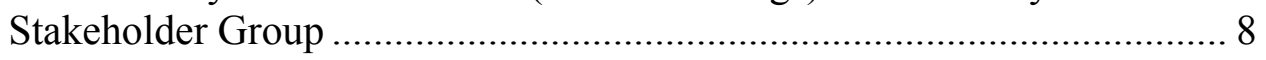

Table 1-3. Affordability-Related Costs (or Benefit Reductions) Classified by Stakeholder Group ……………………............................................... 9

Disclaimer: The comments represent viewpoints of the individuals participating in the workshop and not those of any organization, institution, or stakeholder group. Workshop participants may have mentioned trade names and company products as examples to illustrate their comments. In no case does such mention imply recommendation, endorsement, or judgment by the National Institute of Standards and Technology or the U.S. Department of Housing and Urban Development. 


\section{List of Acronyms}

\begin{tabular}{|c|c|}
\hline AHJ & authority having jurisdiction \\
\hline ASTM & American Society of Testing and Materials, International \\
\hline ATC & Applied Technology Council \\
\hline BCEGS & Building Code Effectiveness Grading Schedule \\
\hline$B F R L$ & Building and Fire Research Laboratory \\
\hline BTI & Building Technology Incorporated \\
\hline$D O D$ & U.S. Department of Defense \\
\hline$D O E$ & U.S. Department of Energy \\
\hline EIFS & exterior insulation finishing systems \\
\hline$E P A$ & U.S. Environmental Protection Agency \\
\hline ESR & evaluation service report \\
\hline FDA & U.S. Food and Drug Administration \\
\hline FEMA & Federal Emergency Management Agency \\
\hline FHA & Federal Housing Administration \\
\hline FNMA & Federal National Mortgage Association (Fannie Mae) \\
\hline GFCI & ground fault circuit interrupter \\
\hline HUD & U.S. Department of Housing and Urban Development \\
\hline HVAC & heating, ventilation, air conditioning \\
\hline$I A Q$ & indoor air quality \\
\hline ICBO & International Conference of Building Officials \\
\hline ICC & International Code Council \\
\hline IRC & International Residential Code \\
\hline ISO & Insurance Services Office \\
\hline$L C C$ & life-cycle cost \\
\hline LEED & Leadership in Energy and Environmental Design \\
\hline$L T V$ & loan-to-value \\
\hline MF & multi-family \\
\hline NAHB & National Association of Home Builders \\
\hline NBS & National Bureau of Standards (forerunner of NIST) \\
\hline NES & National Evaluation Service \\
\hline $\mathrm{NIH}$ & National Institutes of Health \\
\hline NIST & National Institute of Standards and Technology \\
\hline$O \& M$ & operations and maintenance \\
\hline$O A E$ & Office of Applied Economics \\
\hline$O M B$ & U.S. Office of Management and Budget \\
\hline OSB & oriented strand board \\
\hline$Q A$ & quality assurance \\
\hline$Q C$ & quality control \\
\hline PATH & Partnership for Advancing Technology in Housing \\
\hline$P B C$ & performance-based codes \\
\hline PHD & planned housing development \\
\hline PITI & principal, interest, taxes, and insurance \\
\hline$P R D$ & planned residential development \\
\hline$R \& D$ & research and development \\
\hline
\end{tabular}


RIF resource impact factor

ROI return-on-investment

$R U F \quad$ resource utilization factor

SF single-family

SKU Stock Keeping Unit

$U R M B$ unreinforced masonry building 


\section{$1 \quad$ Introduction}

\subsection{Background}

Affordability has always been an important consideration in housing, but its impact on housing choices has usually been informal. With recent changes, such as the addition of affordability as an explicit goal to the International Residential Code, ${ }^{1}$ more and more housing decision-makers are realizing the need to address affordability both explicitly and formally. There is no standard, uniform, or accepted definition of affordability, however, that code officials can use to define and measure affordability. Without a set of guidelines for measuring affordability, manufacturers, code officials, and consumers will not have a clear methodology for evaluating the affordability of alternative or new housing technologies in owner-occupied housing. The NIST project "Affordability Guidelines for Owner-Occupied Housing" will develop those guidelines in collaboration with building community stakeholders. The guidelines will show how to measure and evaluate the affordability of alternative residential building technologies when compared with a conventionally used technology satisfying the same function or code requirement. The guidelines will accommodate multiple measurement methodologies. For example, one such methodology is life-cycle costing as described in ASTM standard practice E 917. ${ }^{2}$ The consensus affordability guidelines resulting from this joint effort will result in a more rapid introduction of new, more cost-effective technologies in housing, thereby supporting HUD's Strategic Goal 1: Increasing the Availability of Decent, Safe, and Affordable Housing in American Communities. ${ }^{3}$

\subsection{Affordability and Technology: Costs, Benefits, and Incentives}

This introduction highlights discussion topics that relate to technology, innovation, and the affordability of housing. ${ }^{4}$ The workshop expanded on these topics by promoting discussions on the connections and relationships between housing affordability and technology and innovation. It focused on the effect of both new innovations and new uses of existing technologies on costs of materials, products, components, and, ultimately, the home. Measurement of housing affordability underlay all the discussions. The relationship between technology, innovation, and affordability will be examined at two scales:

- Technology and innovation at the scale of materials, products, elements, and components of housing.

\footnotetext{
${ }^{1}$ International Conference of Building Officials (ICBO). 2000. International Residential Code for Oneand Two-Family Dwellings. Whittier, CA: ICBO.

${ }^{2}$ American Society for Testing and Materials (ASTM). 2001. Annual Book of ASTM Standards 2001: Volume 04.11 Building Construction. West Conshohocken, PA: ASTM.

${ }^{3}$ U.S. Department of Housing and Urban Development. 2001. Fiscal Year 2002 Annual Performance Plan. Washington, DC: HUD.

${ }^{4}$ It does not address the broader policy, societal, and economic issues that also relate to housing affordability, although the issues comprised a significant proportion of the discussions at the workshop (see Appendices A and B).
} 
- Technology and innovation at the scale of the entire house and its delivery system.

\subsubsection{Technology and Innovation at the Scale of Materials, Products, Elements, and Components of Housing}

Existing technologies and new innovations at this scale penetrate the housing market within the current traditional housing production and delivery system. Innovators who develop new materials, products, elements, or components for housing must recover their costs through the marketplace. If this is to be achieved, it is necessary to examine the flow of costs and benefits that relate to innovations as they enter the housing market under the current production and delivery system and the stakeholders (see Table 1) affected by these costs and benefits. (See Tables 2 and 3 for matrices mapping the potential benefits and costs associated with technology change in housing to broadly defined stakeholder groups.)

Costs of innovation:

- Development costs, including the cost of obtaining code approval.

- First cost of the product.

- Replacement cost at the end of its service life.

- Maintenance and operation costs related to the product.

- Cost of risk of new-technology product uncertainty and failure.

- Poorer performance on aspects of performance that were not the focus of the innovation, such as durability or fire risk.

Benefits of innovation:

- Reduced first cost, such as lower cost materials of acceptable durability.

- Reduced housing maintenance costs.

- Reduced internal housing "operation" costs, such as lower annual fuel costs.

- Reduced external housing "operation" costs, such as lower commuting expenses. ${ }^{5}$

- Reduced vulnerability to natural or manmade disasters.

- Improved performance that cannot be easily monetized, such as improved acoustic privacy, aesthetics, or more easily cleaned surfaces.

\subsubsection{Technology and Innovation at the Scale of the Entire House and Its Delivery System}

Innovations at this scale penetrate the housing market through the creation of an alternative delivery system, since they cannot be accommodated by the current delivery system. The "open building" concept is an example of such an innovation. This concept is based on separation of the building structure and envelope from the finishing of interior spaces, with each produced by a different delivery system, and independently regulated

\footnotetext{
${ }^{5}$ Higher density housing located nearer urban centers that may have higher first and operating costs, but lower transportation costs associated with it.
} 
and financed. It has reportedly been used to produce housing in the Netherlands and in Japan.

Also, at this scale the range of stakeholders is expanded to include:

- Housing finance

- Housing insurance

- Public utilities (water, waste, energy, communication)

- Public services, such as transportation

Costs of innovation:

- Development costs, including the cost of obtaining code approval, which are significantly higher at this scale due to the longer development time and more comprehensive and complex product.

- First cost of the product.

- Replacement cost at the end of its service life.

- Maintenance and operation costs related to the product.

- Cost of risk of new-technology product uncertainty and failure, which can be significantly higher at this scale because of the wider impacts of a total system failure.

- Cost of developing a new delivery system, including finance, insurance, and regulation.

- Cost of new infrastructure entailed by technology at this scale, such as public utilities and public services.

- Poorer performance on aspects of performance that were not the focus of the innovation, such as durability or fire risk.

Benefits of innovation:

- Reduced first cost, such as lower cost materials of acceptable durability.

- Reduced housing maintenance costs.

- Reduced internal housing "operation" costs, such as lower annual fuel costs.

- Reduced external housing "operation" costs, such as less commuting expenses.

- Reduced vulnerability to natural or manmade disasters.

- Improved performance that cannot be easily monetized, such as improved quality of life.

\subsection{Key Concepts}

The following key concepts have been used in the preceding discussion.

Technological innovation in housing, for our purposes, is defined as new ways of designing, constructing, producing, or of combining materials, at each of the scales discussed above. New technologies in housing are often slow to be adopted because of uncertainties about what they will cost stakeholders, both in the short and long run. Yet new technologies can be more cost effective than traditional technologies. Having a set 
of guidelines for measuring the cost effectiveness of new technologies will encourage their consideration and adoption, and accelerate adoption of those new technologies that make sense.

First costs are those incurred at the beginning of a project. The first costs of windows, for example, when examined from the perspective of the homeowner, is what the windows cost to purchase and install. If we compare a traditional window system to a new technology on the basis of first costs, we would say the new technology is affordable on a first cost basis if its cost is less than or equal to that of the conventional technology used to satisfy the same function or code requirement.

Life-cycle costs are all costs associated with a given technology. They include first costs; operations, maintenance, and repair costs over a specified life cycle (e.g., the typical holding period for owner-occupied housing); replacement cost at the end of the life cycle; and any other costs associated with the technology over time. These life-cycle costs could be expressed as monthly mortgage costs (i.e., principal, interest, taxes, and insurance) or monthly holding costs (i.e., mortgage costs plus amortized operations, maintenance, energy, and repair and replacement costs). Thus the life-cycle costs of a new-technology window system would take into account, in addition to the purchase and installation costs (first costs), all costs of repairs, replacement, and even energy savings if the new system resulted in better thermal performance than the conventional system to which it was being compared.

Incentives are important in evaluating affordability because they affect the bottom line of how much building technologies ultimately cost a stakeholder. Cost sharing, tax credits or deductions, and grants to stakeholders will make new housing technologies more affordable when compared with technologies not favored with incentives. If a state government, for example, were to cost share the first cost of residential solar hot water heaters, the life-cycle costs of solar hot water (taking into account reduced energy bills for water heating) could become affordable (i.e., cost competitive) with conventional water heating systems. Cost sharing, tax deductions or credits, and grants to stakeholders, whether taken singly or in combination, all affect stakeholder affordability.

\subsection{Project Description}

There are four steps in the development of the affordability guidelines. The first was the completion of a white paper (that formed the basis for this introductory chapter of the workshop summary). It was used as a background piece by participant stakeholders at the affordability workshop to identify (1) what affordability means to them and (2) what sorts of measurement guidelines and other economic tools would help them.

The second step was to conduct the workshop to provide a framework for discussing key affordability/innovation-related issues. Discussion topics, based on the eight questions (see Section 1.6) and the two scales of innovation presented previously, were developed for use by participants of the affordability workshop to focus their discussion and to get their views on affordability/innovation-related issues. 
The third step will be to develop a consensus roadmap based on the workshop outputs. NIST will explore ways in which reliance on a carefully selected set of standard practices and input from the stakeholder groups can be used to produce a consensus roadmap for developing a set of affordability guidelines. The consensus roadmap will include plans for awareness building and information dissemination. It is believed that this approach will facilitate the deployment of a set of affordability guidelines that can be supported by each of the key stakeholder groups.

The fourth step is the production of the affordability guidelines.

\subsection{Customers and Stakeholders}

Customers are the intended users of the affordability guidelines. A manufacturer who wants to advertise the relative affordability of a new product, for example, could measure that affordability with the guidelines. A consumer who wishes to compare the affordability of a new roofing shingle to conventional shingles is also a customer. These customers are at the same time the stakeholders. Having or not having affordability guidelines makes a difference in their evaluation of housing products. Thus they have a stake in what those guidelines say.

Six key customer/stakeholder groups are (1) homeowners, or their representatives, who wish to select a particular material, product, or system; (2) home builders, remodelers, developers, and their subcontractors, who integrate materials, products, and systems and provide the integrated package to homeowners; (3) innovators, product manufacturers, distributors, and retailers who wish to verify that their material, product, or system meets affordability criteria; (4) code officials and evaluation services who formulate codes or judge if the proposed material, product, or system meets code requirements; (5) real estate, financial, and insurance institutions and their agents; and (6) government programs concerned with housing-related issues (e.g., HUD, FEMA, DOE, and DOD).

Each of these groups was represented at the workshop because housing industry stakeholders are affected in different ways by affordability/innovation-related issues. Participants in the workshop considered alternative measures of affordability and commented on how each of those measures would or would not help them when making choices among housing technologies. Special emphasis was placed on documenting how each stakeholder group looks at affordability.

\subsection{Workshop Discussion Topics}

Eight questions formed the basis for sequential consideration and discussion at the workshop:

1. Who benefits from the innovation? Do the homebuyers or homeowners benefit? If there is a benefit of reduced first cost, does it pass through to the homeowner, or 
does it go into the pocket of someone in the supply chain of the current delivery system? ${ }^{6}$

2. How to "push" the benefits to the homeowner? How can we help the home buyer to see the big picture, e.g., benefits as well as costs, especially initial costs? If a benefit comes at added cost, can the homeowner trade it off against reduced performance somewhere else in the house? Is the production function of housing (the current delivery system) flexible in that way to allow for substitutions among component costs, or is every innovation an "extra expense"?

3. How does each stakeholder view and compute life-cycle costs and benefits compared to first costs?

4. How does each stakeholder view and compute future benefits that are uncertain or contingent on very low probability events, such as protection from earthquakes or hurricanes that may never happen?

5. How should the uncertainty and risk associated with using new versus traditional technology be addressed?

6. How should society value or monetize the social costs and benefits of introducing technology in residential housing, such as energy conservation or disaster relief and recovery?

7. Can the regulatory system be used to encourage innovation, and to distinguish innovations with net benefits from those with net costs?

8. Who should bear the costs of development of new delivery systems and new infrastructure systems that are needed for innovation to penetrate the market at the scale of the entire house and its delivery system?

\subsection{Workshop Procedures}

Each discussion session was introduced by two individuals (leads) who briefly set the stage of possible positions, followed by facilitated discussion of subordinate questions among the full group. Leads were asked to pose divergent initial positions, as possible. Leads and/or facilitators sought to ensure that relationships to affordability guidelines and roadmap development were considered as part of the discussion and recommendations for each session.

\subsection{Expected Outcome}

This report summarizes the needs identified at the workshop for measures for affordability in relation to housing technologies. The report will form the blueprint for making a roadmap of what needs to be done in developing a set of affordability guidelines for owner-occupied housing. By following this blueprint, stakeholders will ultimately have a standardized, accepted definition of affordability that meets their needs and will help them make more cost-effective choices in owner-occupied housing.

\footnotetext{
${ }^{6}$ When the code allowed non-metallic conduit in garden apartments, did the cost of the more expensive system it replaced get transferred from the union mechanic to the electrical contractor, or to the homebuilder, or was the cost to the consumer reduced?
} 
Table 1-1. Affordability and Technology: Hierarchy of Key Stakeholder Groups

\begin{tabular}{|l|l|}
\hline Homeowners & Homeowners \\
& Occupants \\
& Tenants \\
& Neighbors \\
& Homeowners' associations \\
\hline & Home builders \\
& Remodelers \\
\hline Home Builders & Developers \\
\hline General contractors & Subcontractors \\
& Maintenance and repair providers \\
\hline Product Manufacturers & Manufacturers \\
& Innovators \\
& Distributors \\
& Retailers \\
\hline Code Officials & Code officials \\
& Evaluation services \\
\hline Finance & Real estate \\
& Financial institutions \\
& Insurers \\
\hline Government & HUD \\
& FEMA \\
& DOE \\
& DOD \\
State/Local \\
\hline
\end{tabular}


Table 1-2. Affordability-Related Benefits (or Cost Savings) Classified by Stakeholder Group

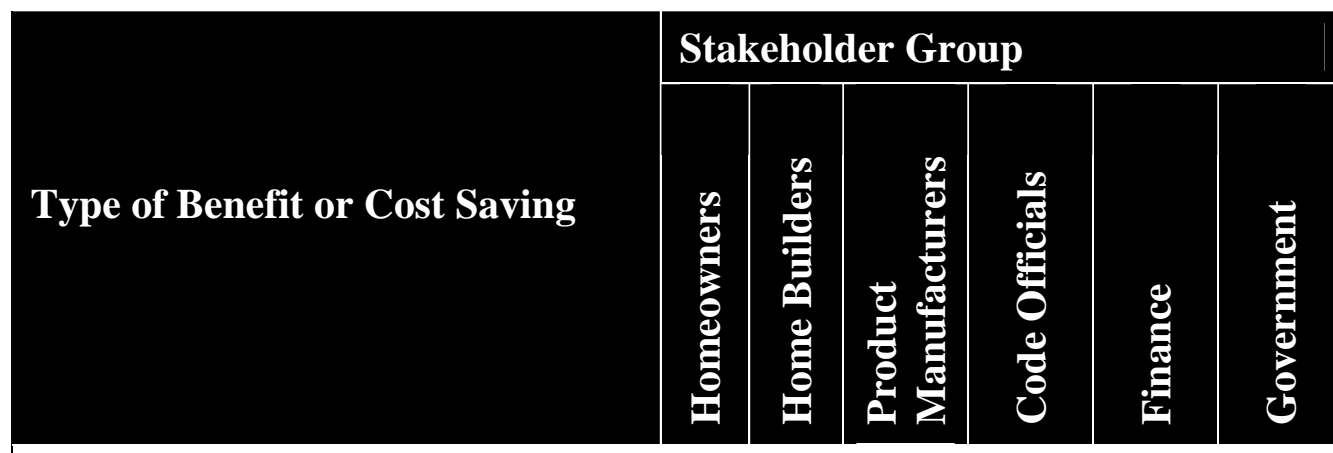

\begin{tabular}{|l|l|l|l|l|l|l|}
\hline $\begin{array}{l}\text { Reduced first cost, such as lower } \\
\text { cost materials of acceptable } \\
\text { durability }\end{array}$ & $\mathrm{x}$ & $\mathrm{x}$ & & & & \\
\hline $\begin{array}{l}\text { Less frequent replacement/longer } \\
\text { product life/improved durability }\end{array}$ & $\mathrm{x}$ & & & & & \\
\hline Reduced housing maintenance costs & $\mathrm{x}$ & & & & & \\
\hline $\begin{array}{l}\text { Reduced internal housing operation } \\
\text { costs, such as lower annual fuel } \\
\text { costs }\end{array}$ & $\mathrm{x}$ & & & & & \\
\hline $\begin{array}{l}\text { Reduced vulnerability to natural or } \\
\text { manmade disasters }\end{array}$ & $\mathrm{x}$ & & & & $\mathrm{x}$ & $\mathrm{x}$ \\
\hline $\begin{array}{l}\text { Improved performance in other } \\
\text { qualities (convenience, comfort, } \\
\text { soundproofing, health) }\end{array}$ & $\mathrm{x}$ & & & & & \\
\hline $\begin{array}{l}\text { Greater demand in marketplace, } \\
\text { increased value of asset or product }\end{array}$ & $\mathrm{x}$ & $\mathrm{x}$ & $\mathrm{x}$ & & $\mathrm{x}$ & $\mathrm{x}$ \\
\hline Reduced susceptibility to shortages & & & & & & \\
\hline $\begin{array}{l}\text { Economic incentives (cost sharing, } \\
\text { tax credits or deductions, grants) }\end{array}$ & $\mathrm{x}$ & $\mathrm{x}$ & & & & \\
\hline $\begin{array}{l}\text { Reduced external housing } \\
\text { "operation" costs, such as lower } \\
\text { commuting expenses }\end{array}$ & $\mathrm{x}$ & & & & & \\
\hline
\end{tabular}


Table 1-3. Affordability-Related Costs (or Benefit Reductions) Classified by Stakeholder Group

\begin{tabular}{|c|c|c|c|c|c|c|}
\hline \multirow[b]{2}{*}{$\begin{array}{l}\text { Type of Cost or } \\
\text { Reduction }\end{array}$} & \multicolumn{6}{|c|}{ Stakeholder Group } \\
\hline & 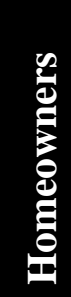 & 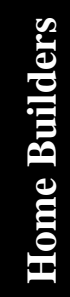 & 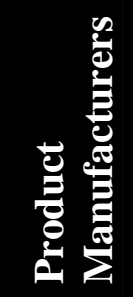 & 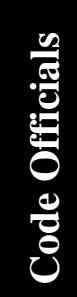 & 导 & 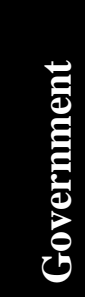 \\
\hline New technology development costs & & & $\mathrm{x}$ & & & \\
\hline Cost of obtaining code approval & $\mathrm{x}$ & $\mathrm{x}$ & $\mathrm{x}$ & $\mathrm{x}$ & & \\
\hline $\begin{array}{l}\text { Cost of introducing and adapting to } \\
\text { new technology: installation and } \\
\text { maintenance training }\end{array}$ & $\mathrm{x}$ & $\mathrm{x}$ & $\mathrm{x}$ & $\mathrm{x}$ & & \\
\hline $\begin{array}{l}\text { Cost of risk of product uncertainty } \\
\text { and failure }\end{array}$ & $\mathrm{x}$ & $\mathrm{x}$ & $\mathrm{x}$ & $\mathrm{x}$ & $\mathrm{x}$ & \\
\hline Cost of economic incentives & & & & & $\mathrm{x}$ & $\mathrm{x}$ \\
\hline $\begin{array}{llr}\text { Reduced sales } & \text { of selected } \\
\text { product/equipment } & \text { lines } & \text { and } \\
\text { associated services } & & \end{array}$ & & & $\mathrm{x}$ & & & \\
\hline Increased marketing costs & & $\mathrm{x}$ & $\mathrm{x}$ & & $\mathrm{x}$ & \\
\hline Higher first cost & $\mathrm{x}$ & $\mathrm{x}$ & $\mathrm{x}$ & & $\mathrm{x}$ & \\
\hline $\begin{array}{l}\text { Replacement cost at the end of } \\
\text { product's service life }\end{array}$ & $\mathrm{x}$ & & $\mathrm{x}$ & & & \\
\hline $\begin{array}{l}\text { Maintenance costs related to the } \\
\text { product }\end{array}$ & $\mathrm{x}$ & & $\mathrm{x}$ & & & \\
\hline $\begin{array}{l}\text { Operations costs related to the } \\
\text { product }\end{array}$ & $\mathrm{x}$ & & $\mathrm{x}$ & & & \\
\hline $\begin{array}{l}\text { Cost of financing (closing costs, } \\
\text { mortgage interest) }\end{array}$ & $\mathrm{x}$ & $\mathrm{x}$ & $\mathrm{x}$ & & $\mathrm{x}$ & $\mathrm{x}$ \\
\hline $\begin{array}{l}\text { Insurance costs } \quad \text { (premium, } \\
\text { deductible, type of coverage) }\end{array}$ & $\mathrm{x}$ & & $\mathrm{x}$ & & $\mathrm{x}$ & $\mathrm{x}$ \\
\hline $\begin{array}{l}\text { Location/Usage costs (convenience, } \\
\text { school district, commuting, crime; } \\
\text { housing size, features, amenities) }\end{array}$ & $\mathrm{x}$ & $\mathrm{x}$ & & & & $\mathrm{x}$ \\
\hline
\end{tabular}




\section{Summary of Discussion Topics}

Workshop discussions covered a wide range of issues. Some of the discussions focused on policy considerations, which are beyond the scope of concerns for this work. The following sections highlight the key points that emerged from each workshop discussion session. All documented comments for each discussion session, arranged in sequence, are presented in Appendix A.

\subsection{Who Benefits from Innovation}

Richard Wright and Carlos Martín, representing homeowners and building/economics researchers, respectively, introduced the question of who benefits by asserting that housing value results from both economic and non-economic factors. Further, any discussion of affordability must address pricing and the uncertainty of being able to recoup an investment in housing. Key discussion points included:

- Prices and pricing are local

- Cost of production (of a dwelling) does not set price, though there are indirect relationships (cost determines whether or not the house will be built)

- Benefits of innovation do not pass directly to home buyers

- Producers make decisions regarding product, not the consumer (who buys a complete package, not a collection of options or attributes)

- Durability may be a key to passing benefits to home buyers and owners

- Buyers focus on their own time horizon (how long they will own the house- not its extended life-cycle; there is no incentive to consider a longer period)

- Lenders define affordability — not builders, not buyers

- Benefits accrue to decision-makers at various points in the production process

- Regulation is a significant factor in housing cost (estimated at $30 \%$ )

- Delivery systems for innovation in new and existing housing are very different

\subsection{How to Transfer Benefits to the Homeowner}

Ed Sutton, representing the builder stakeholder group, and Theresa Weston, representing product manufacturers, led the discussion of delivering innovation benefits to homeowners. Producers and product manufacturers look for market 'pull'. The industry does not 'push' products or benefits to consumers. Communication with the consumer is key to the sales process. The builder is typically the buyer of housing products, not the homebuyer or owner-especially for the new home market. Manufacturers must create value for the builder, and, through the builder, for the homeowner. An innovation cannot trade off performance from one system to another. Key discussion points included:

- Innovation must bring some sought after benefit (a 'hook')

- Builders limit the number of options available to buyers

- Builders and buyers want benefits of innovation at no cost or reduced cost

- Some builders target $80 \%$ of buyer's budget, then allow $20 \%$ for add-on options 
- "See and feel" innovations are easier to sell than hidden changes that may affect/improve durability

- Today, QC/QA (quality control/quality assurance) and business management (non-building considerations) are key to delivery system efficiency improvement

- How does builder/buyer decision-making differ throughout the product adoption/penetration process?

- Buyers do not know what they want, at least until it is shown to them

\subsection{How Does Each Stakeholder View and Compute Costs}

Robert Chapman and Paul Emrath, representing researchers and builders, led the discussion of attitudes toward costs across stakeholder groups. From a buildings research perspective, stakeholder variations occur in discount rate, time horizon, and relevance of costs. Life-cycle analysis is flexible, provides structure, under a wide range of conditions. Time horizons are important to builders as well. Buyers are uncertain of time in home and who will buy when they sell, and so use varying discount rates - in addition, different buyer segments behave differently. Key discussion points included:

- Time horizons increase with income, length of time in the home, and repeat buyers

- Lenders focus on first costs while insurers, communities, and governments have longer time horizons

- Differences between single-family and multifamily markets are significant-age, service life, and condition are considered at multifamily resale

- Standing and position of building code regulation and enforcement representatives as stakeholders in questions of affordability are unclear (although International Residential Code now explicitly cites affordability along with safety as goals)

- It is difficult to juxtapose economics against safety in codes and standards deliberations

- Rare event risk assessment is based on documented actuarial experience

- Home inspections could become the counterpart to due diligence for single-family home resale assessments

\subsection{How Does Each Stakeholder View and Compute Uncertain Future Benefits}

Ed Sutton and Robert Chapman, representing builders and building researchers, introduced a discussion of the effect of uncertainty associated with rare events on decision-making. Visible innovation aids market acceptance of change requirements. But, consumers are largely unable to rationally differentiate risks (may fear low risk more than high risk events). Insurance and taxes may be fruitful areas for incentives to innovation. Minimum acceptable levels of health and safety standards are neither well defined nor understood - much less so for issues such as affordability. Understanding of risk should be based on magnitude, probability, and expected performance during rare events. But, risk-based decisions, such as in determining insurance premiums, may penalize those least able to afford an increase. Key discussion points included: 
- The magnitude of any event is, essentially, the magnitude of the loss that occurs

- Home buyers, in attempting to understand quantitative data in a qualitative way, divide hazards into 'impossible' and 'intolerable' categories (protecting against only the latter)

- There are three types of consumers: one group will choose mediocre performance because they want to avoid the uncertainty, even at a cost of lower performance. The second will choose the high performance option if the uncertainty is controllable by their own actions. A third may choose the high performance/high uncertainty option because they care only about first cost

- Product innovation that relies on maintenance for operation will fail

- Tolerance of deterioration in homes (deferred maintenance) is a problem, at present there is no direct accountability for inaction - how can it be addressed?

- Building condition has extended impacts-building vacancy rate has been found to be a strong indicator of fire frequency for entire neighborhoods

- Increased safety leads to increased costs of housing; the same will be true for all other attributes

- Increased enforcement/adherence (to whatever the standard is) leads to increased housing quality

- There is no guarantee that innovation either lowers costs or increases quality

\subsection{How to Evaluate the Risks of Using Innovative Technologies}

Theresa Weston, representing product manufacturers, and Michelle McDonough, representing lenders, introduced the discussion of uncertainty associated with the use of innovation. Uncertainty includes unforeseen costs, durability of value, and consistency of the capability to measure multiple aspects of innovation. Manufacturers reduce risk in new products by making evolutionary rather than revolutionary changes (with greater chance of failure), by addressing all aspects of impacts on performance, and by developing installation, delivery, and O\&M procedures as the product is developed. Key discussion points included:

- New products are in direct competition with existing substitute products

- Building codes and standards can become barriers to innovation

- Product assessment should involve 3 distinct stages: assessment by manufacturer, controlled assessment by a limited population, then general distribution

- Site assembly by third-parties is a problem-more systems integration (engineered product) is needed.

- To manufacturer, time is a critical factor-extended development and testing takes time off the patent and reduces the value of the innovation to the innovator

- Development of innovations must look closely at even minor portions of costs, such as flashing for windows

- New products often must completely replace an existing product in the supply chain because of marketing and distribution considerations.

- Innovation developers seek standards of acceptance-code compliance acceptance is very important 
- For new products:

○ Manufacturer will understand risk

- Consumer (builder) will overestimate risk

- Both will try to shift risk to someone else

- Ultimate consumer (home buyer) probably least able to afford risk

\subsection{How to Measure the Social Costs and Benefits of Innovative Technologies}

Michelle McDonough, representing lenders, and Ron Piester, representing building code regulators, introduced the discussion of social costs and benefits in housing. There is a difference between 'valuing' and 'monetizing' social aspects of housing. Similarly, there are differences between 'general stakeholders' (e.g. regulators and repairmen) and 'stakeholders with standing' that have a direct economic investment in housing. In terms of distribution of costs and benefits, lenders are far more concerned with negative impacts on low-income buyer segments (which are much more susceptible to adverse effects). Social costs vary depending on the geographic/political level at which they are considered and are highly subjective.

Rather than direct stakeholders, code regulators are key players/actors in expressing and promoting societal valuation of housing and housing innovation. The government must assess the effectiveness of 'incentive' versus 'regulation/mandate'. The government must determine a threshold for action based on perceived risk or lose public trust. The public will reject increased cost until they recognize benefit, then they will embrace action. The public does not want to pay more for a 'mandated' action.

Key discussion points included:

- Social valuation may be considered as the act of maximizing wealth (of the community) through regulations or incentives that address factors which are not obvious and visible - "internalization of externalities"

- The multifamily delivery system internalizes external costs for many actors, reflecting the difference between a private transaction (such as that for singlefamily house) and a public (regulated) transaction

- Benefits do not have to go only to society, but can go to the entrepreneur-the person who starts the change/takes the initial risk, makes the money-by removing regulations and other barriers to innovation

- On the other hand, regulations are used to compensate for the fact that "natural costing" does not automatically account for all costs

- Lack of agreement on assessment parameters often prevents policy decision making - decision makers cannot rely on staying power of policy analysis

- The home buyer views the product (housing) as a durable asset, internalizing all perceived costs

- Durability of the asset (housing) could and should be better understood by all stakeholders 


\subsection{How Can the Regulatory System Be Used to Encourage Innovation}

John Hall and David Conover, each representing model code developer perspectives, introduced the discussion of the use of regulation to encourage innovation.

Most regulation is intended to advance not affordability, but some other factor, primarily safety. Many regulators want to trust what they know works - prescriptive standardsfeeling that performance approaches may undercut effectiveness of standards and may be more difficult to evaluate. Innovation may exacerbate performance-based evaluation concerns. In addition, lack of a common language is a problem-economists and policy makers want to express all concerns in dollars. The key point is that we don't need less, we need better regulation - the advocated approach favors modeling, yielding "smart regulation audited with civility."

Can the regulatory system be used to encourage innovation? Yes. Factors must be identified and explored. What is needed is a baseline level to exceed. For life-safety issues, codes and standards typically lag technology development. If non-prescriptive, there is no information on which to base approval/acceptance. A recent Washington Post column $^{7}$ on regulation cites three needs:

- Information based on good research

- Willingness and ability to defend analysis tools

- Implementation policies that encourage smart life-saving analyses

Key points in the ensuing discussion included:

- There is no evidence that more innovation occurs under one or the other scheme of regulation (performance-based or prescriptive)

- The presumption is that performance-based requirements may encourage innovation through offer of options (such as compliance options in New York)

- Conversely, a serious vulnerability of the present regulatory structure is confidence that prescriptive codes achieve desired purposes/objectives (a confidence which may be unwarranted)

- Looking at other industries for guidance, there is a strong trend that deregulation spurs innovation

- Recommend research to model an insurance-based approach to encouraging housing innovation; determine appropriate government roles (analogous to selfamortizing mortgages); determine feasibility

- However, Type 1 and Type 2 statistical errors have a role in evaluating the effectiveness of innovation - there is a need to look at the existence of both 'good' and 'bad' innovation

- Before 'affordability' can be defined, 'safety' (in terms of "acceptable risk") needs to be defined - there is currently no generally accepted definition

\footnotetext{
${ }^{7}$ Hahn, Robert and Scott Wallsten, "Whose Life is Worth More? (And Why Is It Horrible to Ask?)," Washington Post, June 1, 2003, pp B3.
} 
- Because it is unclear what the code means in terms of performance (and not measurable), innovation will not occur as long as acceptance decision-making remains local

- The fundamental need is to determine what is an "acceptable level of risk" and then protect against it through regulatory enforcement

\subsection{Who Should Bear the Costs of New Delivery Systems for Innovative Technologies}

Paul Emrath, representing the builder stakeholder group, and Theresa Weston, representing product manufacturer perspectives, introduced the discussion of who should bear costs of improved product delivery systems.

Mandated innovation is disproportionately a burden to low-income home buyers. Owners are interested in restricting supply to protect the value of their assets. Politicians have an interest in protecting asset value as well. In considering a new delivery system, how would it be regulated? Would local regulators necessarily lose control of the process?

Development costs for new delivery systems at whatever scale will get passed to the consumer, and, even so, will not be undertaken by intermediate participants if the costs are too high. If builders cannot pass on at least part of the costs, they will not buy. The question is not who pays, but how costs are distributed.

Key discussion points included:

- Builder will pay the costs of the new delivery process at the outset, but will pass along to home buyer as soon as possible

- Government has moved away from any consideration of 'command and control' strategies (such as 'operation breakthrough' in the '70s)

- Today, vertical integration, engineered systems, and modular integration are the strongest approaches to changing housing delivery - trades and agencies should get together and decide on a course of action

- A 'pilot project' (in an analogy to medical industry practices) would produce not total change, but an immediate test of the effects of changes

- Conversely, a 'pilot project' may conflict with existing infrastructure; change may be viewed as negative - if the pilot is big, it may be blocked by existing industry and a consumer afraid of reduced asset value.

- Recommend a feasibility study — is there a role for government in a test of changing housing delivery?

- No individual will put up with any cost to change this delivery. Who will pay?

- Need a delivery system to routinize rehab and reuse-introduce innovation through rehab rather than new construction

- Conversely, while there is a clear need for innovation in the existing housing stock, most new products will be for new construction- 50 million new buyers over the next 50 years will push new development (even though they may enter market through purchase of existing stock) 


\section{Summary of Stakeholder Perspectives}

Eight stakeholder groups were represented at the meeting. This list of stakeholders is a variation on the six identified in section 1.5 of this report. The code officials and evaluation services were separated to reflect the different roles that local code officials and model code developers play. The "government programs" stakeholder of section 1.5 was redefined to focus on the perspectives of researchers in both government and academia (as opposed to government regulators, housing providers, or emergency responders). Added to the list of stakeholders are consultants who play a role in housing delivery through their interactions with the other stakeholders.

- Owners: homeowners, representatives of homeowners, and homeowner associations who wish to select a particular material, product, or system

- Builders: home builders, remodelers, developers, and their subcontractors, who integrate materials, products, and systems and provide the integrated package to homeowners

- Building Product Manufacturers: innovators, product manufacturers, distributors, and retailers who wish to verify that their material, product, or system meets affordability

- Model Codes Developers: those who work in international and national codesand standards-developing bodies

- Building Code Regulators: local and state government agencies responsible for code adoption and implementation

- Lenders

- Buildings/Economics Researchers in academia and government

- Consultants

Following the workshop, comments documented during discussion sessions were sorted and reviewed to develop a sense of the perspectives presented for each stakeholder group. Each stakeholder comment was judged to refer primarily to one of nine keyword topics that recurred across all discussion sessions:

- Attribute: affordability, durability, safety, etc. (flexibility, substitutability, customizability)

- Barrier/Incentive: (to market acceptance)

- Delivery system: (for housing and housing products)

- Market: supply-chain, builder, homebuyer, investor

- Metric: $1^{\text {st }}$, annual, life-cycle, time-horizon, units-of-measurement, uncertainty, market signal, rating scale

- Perspective: interest, standing, constituents

- Product: development, test/evaluation, distribution, sale

- Segmentation: Multi-family/Single-family, new/existing, low-income/highincome

- Value: cost, price, benefit [val] 
The following sections highlight key points reflecting the perspectives expressed for each stakeholder group over the course of the entire workshop. All documented comments for each stakeholder group, arranged by keyword topic, are presented in Appendix B.

\subsection{Owners}

- Community concerns should be considered; they may be the ultimate benefactors of innovation

- High maintenance is not a reliable strategy for low frequency events; need failsafe systems

- We need to determine what is an "acceptable level of risk" and then protect against it

- ICC and rehab codes are steps in the right direction - going to a statewide code increases consistency in enforcement

- For low-income housing, a $3^{\text {rd }}$-party has joined the transaction and regulates decision-making; that is not present in the private-sector single-family market

- We need to change terms of reference for risk - a 100 year flood is as likely again next year as this year

- Low-income buyer is a different market; must balance current social taste, income limits, performance of home - tradeoffs must be made and high maintenance cost is a key issue

- While housing production cost may not determine selling price, cost will determine whether housing is built

\subsection{Lenders}

- The biggest problem is functional obsolescence of housing; today will not be tomorrow in all dimensions, including operating cost concerns

- What is the quality level for 'affordable' housing — safer means higher cost; will be the same for all attributes

- Risk-based insurance may have contrary effect of increasing cost to those that can least afford it

- Innovation in lending has led to greater purchasing power (most significant contribution to housing affordability over last two decades)

- While the debt ratio is determinant, the multi-family (MF) delivery system explicitly considers age, service life, and condition at resale - must consider the viability of the structure (due diligence) - home inspections could serve a similar purpose for single-family (SF) delivery

- A metric is needed to decide between increased regulation and deregulation

- Codes can only address a minimum level of safety

- There is a difference between 'valuing' and 'monetizing' and social value is highly subjective

- Is affordability the "ability to pay" or the "cost to build"? The value of housing is "what it will sell for"; it's a competitive market, but the cost of building (production) does not set the price 
- Individual choices do not affect expected resale value (time horizon can be critical to decision making)

- If it is worth something, lenders will underwrite it

\subsection{Builders}

- Interested in minimum health and safety standards

- Innovation cannot rely on maintenance for operation - product will fail

- Before you can define 'affordability', you need to define 'safety'

- Regulation is the key to 'affordability' (represents $30 \%$ of the cost of housing)

- Today, QC management/business systems and non-building considerations lead in importance; $70 \%$ of tradesmen have no employees

- A big problem for builders is how to train producers/installers (laborers); ability to train will be a big component of acceptance of innovation

- Insurance companies have an opportunity to reduce their own risk through riskbased underwriting (encourage rather than force acceptance)

- Product evaluation reports are limited only to existing code requirements and do not test against purposes of innovation (whatever those may be, such as durability)

- New technology often must completely replace something already out there-a tough sell

- Mandated innovation is disproportionately a burden to low-income buyers of housing

- No individual will put up with any cost to change product delivery

- Consumer does not want durability, consumer wants upgraded carpet

$\circ$ Buyer is buying a complete product package

- Builder has difficulty in accommodating 'menu' of product choices (especially for spec building)

- Buyer expects minimum level of durability

- Consider concept of 'durability rating' system/policy

○ Single number, $0-100$

- Market compensation of rating (higher resale for higher rating)

- As a rule-of-thumb, builder may want to price at $80 \%$ of buyer's budget, then add unforeseens, and widgets that are wanted (product 'pull')

- Time horizons apply to builders as well; builders are not opposed to LCC analysis

- Buyers are uncertain of time in home, who will buy, and so use varying discount rates

- It is difficult to argue safety versus economics in a public forum

- Deterioration takes place over time - it costs $\$ 1800 /$ year to maintain housing, $\$ 237 \mathrm{~K}$ is the average resale cost of a house; thus, homeowners spend only $1 \%$ of house value on their single most valuable asset each year

- Rental property investor seeks $1 \%$ property + improvement cash flow in stable market; delay in maintenance will penalize the seller; how much? (subject of study?)

- Long term interests align regulators and existing building owners 
- Need innovation not in widgets and hard things, but in regulation-such as opportunities implicit in implementation of rehab codes

- We see indications of marketplace changes, but cannot yet confirm

- Appraised value is a blunt instrument (and should be more sensitive)

- The question remains - how to value a parameter in order to have a basis to set a fee-the consumer views the product (housing) as a durable asset, internalizing ALL perceived costs

\subsection{Building Product Manufacturers}

- Regulation typically does not promote or discourage change

- Code training is part of the product development process

- Development costs will get passed to the consumer, and, even so, will not be undertaken if too high - if builders cannot pass on at least part of the costs, they will not buy

- Builder will pay the costs of a new delivery process at the outset, but will pass along as soon as possible

- Perhaps we should focus on changing delivery of existing stock rehabilitation

- We identify where 'pull' is from and address need; use multiple channels to reach the consumer; look at complete LCC, including replacement cycles

- Applied research is done well privately; basic research is no longer being done by the federal government

- We reduce our risk in introducing new products in four ways:

○ Evolution is manageable; revolution involves unforeseen issues (with greater chance of failure)

- Assessing performance must be addressed in all areas of impact.

O ASTM standard E 1825 lists things to look at.

o Should develop installation and delivery system as product is developed

- Prescriptive standards represent "the way things have been done"-new product must test against existing product and evaluate existing product for comparison

- Goal is to find the hook for the consumer and innovate to the hook

- Each consumer uses own set of values and beliefs in personal decision-making

\subsection{Building Code Regulators}

- Community interests must be considered; long-term interests matter to lenders

- Performance-based requirements can encourage innovation through offer of options (compliance options in the case of NY State)

- Local officials need assurance-binding interpretation, although not often done, is a useful tool

- The state and local regulators are interested in both 1st costs and LCC

- Building regulators are accountable to the political jurisdiction

- It is a complicated role, but the state owns a lot of property (and has a direct stake at least to that extent)

- Effectiveness of 'incentive' v. 'regulation/mandate'-government must determine threshold based on perceived risk or lose public trust 
- Public will reject increased cost until they recognize benefit, then they will embrace action

- Public does not want to pay for a 'mandated' action

- Recent study of contributing factors to fire has found vacancy a strong indicator and greater frequency of vacancy in poor areas

- Innovation costs must be a consideration

\subsection{Model Codes Developers}

- If you ignore maintenance, you are playing probabilities

- Need more realistic estimates of affordability

- Most regulation is intended to advance not affordability, but some other factor, primarily safety

- Lack of a common language is a problem — economists and policy makers want to express all concerns in dollars

- We don't need less, we need better regulation - the advocated approach favors modeling, yielding "smart regulation audited with civility"

- For life-safety issues, codes and standards typically lag technology development

- If non-prescriptive, there is no information on which to base approval/acceptance

- Effective regulation requires information based on good research, ability to defend analysis tools, and implementation policies that encourage smart lifesaving analyses

- There are, in fact, mathematical definitions for safety in the codes

- Regulators provide a function - that function must be acceptable to those being regulated in order for the system to work effectively

- What about improved design, equivalent performance, and innovation? Is delivery system capable of flexibility?

- Recommend going beyond durability—consider a series of scales/indexes with differing parameters

- Uncertainty is the issue for performance measures:

○ Want to align 'who decides' with 'who receives the benefits or pays the costs'

- Various stakeholders/decision-makers come in at different points in the delivery process with different interests

- While the energy issue was driven by economics and 'easy' LCC analysis; LCC is more difficult as you move to life-safety and other issues

- Most stakeholders ignore low probability events - handling quantitative info qualitatively

- Frame cost/benefit against another reference (e.g. value of investment)

- Type 1 and Type 2 statistical errors have a role in evaluating the effectiveness of innovation - need to look at existence of both 'good' and 'bad' innovation

- How does each stakeholder decide what to consider — can we affect the process of that decision?

- Regulators come as close as any stakeholder in looking at all considerations

- Codes are an imperfect but valuable instrument

- Find a way to keep good products alive long enough to check performance 
- Interactions (among stakeholders) are a key aspect in changing product development

- States should be careful of taking on product certification functions (e.g., Florida example); it could increase complexity, uncertainty, and cost

- Abandonment of property leads to leveraged risk for others

- Need a delivery system to routinize rehab and reuse-Introduce innovation through rehab rather than new construction

- There is no guarantee that innovation either lowers costs or increases quality

\subsection{Buildings/Economics Researchers}

- 'Affordability' is whatever Fannie Mae and Freddie Mac say it is: principal, interest, taxes, and insurance (PITI)

- Home insurance industry is not responsive to efforts to get them to consider incentives for durability - great variation from state to state, no rational relation to housing quality

- There are too many gatekeepers; find other ways to protect buyers, such as "builders insurance"

- Suggest that government undertake research/modeling of insurance-based approach to housing innovation; determine appropriate government roles (analogous to self-amortizing mortgages); determine feasibility

- The housing industry is so fragmented, no single organization is large enough to overcome barriers to innovation

- Consider a system of binding interpretation to promote consistency in code enforcement

- All products must be sent to a $3^{\text {rd }}$ party for installation-systems integration is needed

- Government has moved away from any consideration of 'command and control' strategies

- Product 'branding' and 'bundling' may stimulate demand

- It may be possible to interest the consumer to be concerned about the $1^{\text {st }}$ resale period, but not the $15^{\text {th }}$ cycle

- Emphasize the study period for LCC analyses (longer horizons introduce additional concerns)

- Stakeholder variations occur in discount rate, time horizon, and relevance of costs

- LCC analysis is flexible and provides structure under a wide range of conditions

- Studies of recapture of costs for storm mitigation indicate a market signal (visible innovation) aids market acceptance

- Risk perception studies indicate consumers cannot differentiate risks

- Policy makers should consider incentives, such as insurance premium reductions or reduced community costs recognized through transfer tax credits if dwelling is improved

- Metrics are not yet available to either estimate or justify increased costs

- Much of visible innovation is by small companies with low capitalization looking to push innovation into market with little testing or success 
- Consider a 'pilot project' as an approach (analogy to medical industry); allows not total change, but immediate test of change

- Homeowners are not a homogenous group; $2^{\text {nd }}$ time buyers have much different interests than $1^{\text {st }}$ timers

- There are definite stages of innovation penetration and adoption--how is decisionmaking different from group to group?

- The delivery system for multifamily housing internalizes external costs for many actors--it reflects the difference between a private transaction and a public transaction

- While there is a clear need for innovation in existing housing stock, most new products will be for new construction- 50 million new buyers over next 50 years will push new development even though buyers may enter the market through the purchase of existing stock

- Homebuilders must compete by adding value

- Housing is the only industry to insist that innovation requires increased costs

\subsection{Consultants}

- Durability measurement has been supported by component manufacturers, opposed by materials suppliers, and opposed by builders (because it is already factored into markets)

- The ability to provide customization of components is an advantage for builders

- We need to ask why we are concerned with social costs:

$\circ 3^{\text {rd }}$ party effects are fair game for incentives

- Mandates should not be based on externalities

o Externalities should be viewed very skeptically

- Confidence that prescriptive codes achieve desired purposes/objectives may be unwarranted

- Consider a role for government in a test of changing housing delivery

- Determine how to communicate magnitude, probability, and performance to each stakeholder group

- Product certification should recognize contractual trade influences and impacts 


\section{$4 \quad$ Next Steps}

In examining the question of measuring affordability of housing and the impact of housing technologies on affordability, it may be helpful to consider several factors in addition to the stakeholder perspectives presented in chapter 3 . The housing market, its delivery system, proposed metrics and attribute characteristics, regulation, and innovation all play a part in the affordability of housing. Treatment of these concepts is based on questions motivated by the workshop discussions as described in the following sections.

The answers to these questions, which are largely quantitative, would need to be addressed in developing economic measures of housing affordability. The first steps in the development of a roadmap for affordability guidelines will be to rank the importance/priority of each question, define the sequence in which each should be considered, and identify source materials or study references.

\subsection{Housing Market Considerations}

\begin{tabular}{|l|l|}
\hline $\begin{array}{l}\text { Affordability Guideline Development } \\
\text { Roadmap Questions }\end{array}$ & Triggering Workshop Comments \\
\hline $\begin{array}{l}\text { What is the sensitivity of housing prices } \\
\text { to housing production costs? }\end{array}$ & $\begin{array}{l}\text { Prices/Pricing are local } \\
\text { Pretty competitive market, but cost of building } \\
\text { (production) does not set price }\end{array}$ \\
\hline $\begin{array}{l}\text { What is impact of price sensitivity on } \\
\text { housing supply and demand? (Interest } \\
\text { rates? Insurance? Taxes?) }\end{array}$ & $\begin{array}{l}\text { Is affordability the "ability to pay" or the "cost to build" } \\
\text { There are indirect relationships between the cost of } \\
\text { production and the supply of housing } \\
\text { Innovation in lending has led to greater purchasing power }\end{array}$ \\
\hline $\begin{array}{l}\text { What are disaggregated costs of housing } \\
\text { production (land, materials, labor, } \\
\text { management/administration, marketing, } \\
\text { financing)? }\end{array}$ & $\begin{array}{l}\text { How do you introduce efficiencies into product delivery } \\
\text { system? (QC managementbusiness systems) } \\
\text { Non-building considerations lead in importance today; } \\
70 \% \text { of tradesmen have no employees }\end{array}$ \\
\hline
\end{tabular}




\subsection{Housing Delivery System}

\begin{tabular}{|l|l|}
\hline $\begin{array}{l}\text { Affordability Guideline Development } \\
\text { Roadmap Questions }\end{array}$ & Triggering Workshop Comments \\
\hline $\begin{array}{l}\text { What is the process for housing decision- } \\
\text { making (during initial design and } \\
\text { construction and throughout service } \\
\text { life)? }\end{array}$ & $\begin{array}{l}\text { Shift buyer emphasis from 1st cost to life cycle costs; look } \\
\text { at incentives to emphasize LCC } \\
\text { Homeowner is given no options/choices; upstream } \\
\text { decision makers decide. }\end{array}$ \\
\hline $\begin{array}{l}\text { What are innovation delivery system } \\
\text { differences between new and existing } \\
\text { housing? } \text { (Single and } \\
\text { multifamily?) }\end{array}$ & $\begin{array}{l}\text { Existing stock dwarfs new construction; delivery systems } \\
\text { for innovation in new and existing housing are very } \\
\text { different }\end{array}$ \\
\hline $\begin{array}{l}\text { How can existing stock rehabilitation be } \\
\text { made more efficient (routinized)? }\end{array}$ & $\begin{array}{l}\text { Could be the subject of study-is there a role for } \\
\text { government in a test of changing housing delivery? } \\
\text { Perhaps we should focus on changing delivery of existing } \\
\text { stock rehabilitation. } \\
\text { Intent is to make rehab much more frequent (spurring } \\
\text { innovation) and make delivery easier. }\end{array}$ \\
\hline
\end{tabular}

\subsection{Attribute Metrics}

\begin{tabular}{|l|l|}
\hline $\begin{array}{l}\text { Affordability Guideline Development } \\
\text { Roadmap Questions }\end{array}$ & Triggering Workshop Comments \\
\hline $\begin{array}{l}\text { How do stakeholder perspectives, } \\
\text { actions, and reactions differ? }\end{array}$ & $\begin{array}{l}\text { How does each stakeholder decide what to consider? } \\
\text { How are uncertainties...monetized? }\end{array}$ \\
\hline $\begin{array}{l}\text { What are/could be important economic } \\
\text { 'measures of performance' for each } \\
\text { stakeholder? }\end{array}$ & $\begin{array}{l}\text { Frame cost/benefit against another reference (e.g. value } \\
\text { of investment) }\end{array}$ \\
\hline $\begin{array}{l}\text { How should housing quality be } \\
\text { measured? }\end{array}$ & $\begin{array}{l}\text { Clarify the role of Type 1 and Type 2 statistical errors in } \\
\text { evaluating the effectiveness of innovation. Need to look } \\
\text { at both sides of the issues-existence of both 'good' and } \\
\text { 'bad' innovation. }\end{array}$ \\
\hline
\end{tabular}




\begin{tabular}{|c|c|}
\hline $\begin{array}{l}\text { How can parameters of concern be } \\
\text { integrated into property valuation } \\
\text { processes? }\end{array}$ & $\begin{array}{l}\text { Appraised value is a blunt instrument (and should be } \\
\text { more sensitive) }\end{array}$ \\
\hline $\begin{array}{l}\text { How long does housing last and how does } \\
\text { maintenance affect service life? }\end{array}$ & $\begin{array}{l}\text { The issue is a mathematical problem and not that difficult } \\
\text { to understand: \$trillion value of stock, divided by the } \\
\text { number of units, plus annual cost of maintaining times } \\
\text { service life, divided by service life equals annual cost of } \\
\text { ownership. } \\
\text { Concept makes a lot of sense except for characterization } \\
\text { as "simple" problem-we do not know how long housing } \\
\text { lasts. Pricing in durability may be useful, but may not. }\end{array}$ \\
\hline $\begin{array}{l}\text { What is the relationship of durability } \\
\text { (and/or other parameters) to costs }\left(1^{\text {st }} \text {, }\right. \\
\text { maintenance, and LCC)? }\end{array}$ & $\begin{array}{l}\text { Consider concept of 'durability rating' system/policy } \\
\text { Market compensation of rating (higher resale for higher } \\
\text { rating) }\end{array}$ \\
\hline $\begin{array}{l}\text { What is } \quad \text { a } \\
\text { acceptable/expected level of durimimum' } \\
\text { (and/or other parameters)? }\end{array}$ & $\begin{array}{l}\text { Buyer is buying a complete product package; expects } \\
\text { minimum level of durability } \\
\text { Consider series of scales/indexes with differing } \\
\text { parameters. }\end{array}$ \\
\hline $\begin{array}{l}\text { What time horizons should be considered } \\
\text { for economic decision-making? }\end{array}$ & $\begin{array}{l}\text { Time horizon can be critical to decision making. } \\
\text { Community interests must be considered; long-term } \\
\text { interests matter to lenders. }\end{array}$ \\
\hline
\end{tabular}




\subsection{Role of Regulation}

\begin{tabular}{|c|c|}
\hline $\begin{array}{l}\text { Affordability Guideline Development } \\
\text { Roadmap Questions }\end{array}$ & Triggering Workshop Comments \\
\hline $\begin{array}{l}\text { What is impact of regulation on housing } \\
\text { production costs and pricing? }\end{array}$ & $\begin{array}{l}\text { Uncertainty is the issue with performance measures } \\
\text { Suggest "dynamic constrained optimization" } \\
\text { We need actions to reduce constraints and/or free-up } \\
\text { constraints } \\
\text { Regulation is the key (represents } 30 \% \text { of the cost of } \\
\text { housing) }\end{array}$ \\
\hline $\begin{array}{l}\text { What are impacts of externalities on } \\
\text { housing stakeholder risk? }\end{array}$ & $\begin{array}{l}\text { From regulator perspective, recent looks at contributing } \\
\text { factors to fire found vacancy a strong indicator and } \\
\text { greater frequency of vacancy in poor areas } \\
\text { Abandonment of property leads to leveraged risk for } \\
\text { others }\end{array}$ \\
\hline
\end{tabular}

\subsection{Innovation}

\begin{tabular}{|l|l|}
\hline $\begin{array}{l}\text { Affordability Guideline Development } \\
\text { Roadmap Questions }\end{array}$ & Triggering Workshop Comments \\
\hline How does innovation affect quality? & $\begin{array}{l}\text { No guarantee that innovation either lowers costs or } \\
\text { increases quality }\end{array}$ \\
\hline $\begin{array}{l}\text { What factors promote or discourage } \\
\text { innovation? How? }\end{array}$ & $\begin{array}{l}\text { Do we have any evidence that more innovation occurs } \\
\text { under one or the other scheme of regulation? }\end{array}$ \\
\hline
\end{tabular}




\section{Appendix A Individual Comments Organized by Discussion Topic}

The NIST/PATH workshop, Measuring and Assessing the Consequences of Technology and Innovation for Affordability of Housing, consisted of eight sequential discussions over the two-day period.

Over the course of the workshop, distinct comments by individuals were captured on "flip charts" as a running summary of the discussions. Several additional comments by individuals were identified through a synthesis review of notes taken by NIST participants. After the workshop all the comments were reviewed and sorted in a variety of ways to clarify and distill key points and recommendations.

The discussion sorting process involved the characterization of each documented comment in terms of the session and sequence in which it occurred, a keyword describing the underlying topic to which it was judged to refer, and the stakeholder perspective the individual making the comment was representing.

The tables below present each comment using the following format: keyword; discussion session, sequence of remarks, stakeholder group, remark/item, NIST notes synthesis.

Keywords: The workshop discussions consisted not of direct answers to the questions posed to the group but, rather, comments about different aspects of housing, innovation, markets, perceptions, etc. After review of all the discussions, individual comments were judged to refer primarily to one of nine keyword descriptors.

- Attribute: affordability, durability, safety, etc. (flexibility, substitutability, customizability) [att]

- Barrier/Incentive: (to market acceptance) [bar]

- Delivery system: (for housing and housing products) [del]

- Market: supply-chain, builder, homebuyer, investor [mar]

- Metric: $1^{\text {st }}$, annual, life-cycle, time-horizon, units-of-measurement, uncertainty, market signal, rating scale [met]

- Perspective: interest, standing, constituents [per]

- Product: development, test/evaluation, distribution, sale [pro]

- Segmentation: MF/SF, new/existing, low-income/high-income [seg]

- Value: cost, price, benefit [val]

Discussion Sessions: Eight question-based topics were posed to the group for discussion in separate sequential hour-long sessions over the two-day meeting. [Session \#2 was conducted "out of order" after session \#5 due to a schedule conflict.]

- \#1: Who benefits from the housing innovation, both at component scale and at the scale of the entire house and its delivery system? [ben]

- \#2: How to "push" innovation benefits to the homeowner, at the scale of housing components? [push]

- \#3: How does each stakeholder view and compute life-cycle costs and benefits 
compared to first costs, at both scales? [comp]

- \#4: How does each stakeholder view and compute future benefits that are uncertain or contingent on very low probability events, such as protection from earthquakes or hurricanes that may never happen, at both scales? [cert]

- \#5: How should the uncertainty and risk associated with using new versus traditional technology be addressed, at both scales? [risk]

- \#6: How should society value or monetize the social costs and benefits of introducing technology in residential housing, such as energy conservation or disaster relief and recovery, at both scales? [soc]

- \#7: Can the regulatory system be used to encourage innovation, and to distinguish innovations with net benefits from those with net costs, at both component scale and at the scale of the entire house and its delivery system? [reg]

- \#8: Who should bear the costs of development of new delivery systems and new infrastructure systems that are needed for innovation to penetrate the market at the scale of the entire house and its delivery system? [cost]

Stakeholder Groups: Eight stakeholder groups were represented at the meeting.

- Owner [own]

- Lender [fin]

- Builder [bld]

- Building Product Manufacturer [mfr]

- Building Code Regulator [reg]

- Model Codes Developers [mcd]

- Buildings/Economics Research [rch]

- Consultants [cst]

$\underline{\text { Sorts: }}$

Several "sorts" of workshop comments were developed in order to derive recommendations across all the discussions. This appendix consists of "Sequential Comments" in the order documented in the discussion sessions. The resulting tables present, in columns from right to left, the keyword assigned to the comment, the sequential identification of the comment, the stakeholder group that made the comment, the 'flip chart' record of the discussion (items not captured on the flipcharts but recorded by NIST are listed as "see notes"), and a synthesis of notes taken by NIST participants. Appendix B consists of comments first sorted by stakeholder group affiliations and then by keyword topics.

Discussion session \#1: Who benefits from the housing innovation, both at component scale and at the scale of the entire house and its delivery system? (ben) Do the homebuyers or homeowners benefit? If there is a benefit of reduced first cost, does it pass through to the homeowner, or does it go into the pocket of someone in the supply chain of the current delivery system? 


\begin{tabular}{|c|c|c|c|c|}
\hline 离 & 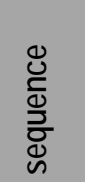 & 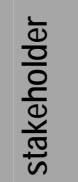 & 'flip chart' record & NIST notes \\
\hline per & 1.01 & rch & $\begin{array}{l}\text { Stakeholder groups: } \\
\text { - Homeowners } \\
\text { - Homebuilders } \\
\text { - } \quad \text { Product manufacturers } \\
\text { - Complementary groups } \\
\text { interested in longevity after } \\
\text { construction-lenders, } \\
\text { insurers, community, etc. }\end{array}$ & $\begin{array}{l}\text { Defining: Who benefits from the technology? } \\
\text { Major stakeholders: } \\
\text { 1. Homeowners } \\
\text { 2. Home builders: affect costs; are key leverage point } \\
\text { in passing along costs, and bringing technology and } \\
\text { benefits to home buyers } \\
\text { 3. Product manufacturers } \\
\text { 4. Housing institutions: lenders, insurers, utilities. } \\
\text { Affected by longevity of house after construction } \\
\text { and how house is utilized after construction } \\
\text { Need to look at life-cycle costs (LCC). }\end{array}$ \\
\hline val & 1.02 & own & $\begin{array}{l}\text { Scales of concern: } \\
\text { - Materials and components } \\
\text { - Delivery system/satisfaction of } \\
\text { broader concerns } \\
\text { - Both economic and non- } \\
\text { economic factors } \\
\text { How do we quantify 'value'? } \\
\text { Must deal with marketplace issue of } \\
\text { 'pricing' (uncertainty of recoupment } \\
\text { of investment) }\end{array}$ & $\begin{array}{l}\text { Look at two scales of affordability: } \\
\text { 1. Components and materials } \\
\text { 2. System: at this scale, there is a more } \\
\text { complex relationship among stakeholders, } \\
\text { community, homeowners. } \\
\text { Must consider LCC in affordability. There are } \\
\text { economic and non-economic factors, but must make } \\
\text { them as quantified as possible with the components } \\
\text { and system. The challenge of the question of } \\
\text { affordability is to define, specify, and guide affordability. } \\
\text { There is the market issue of pricing, from the raw } \\
\text { materials to labor to the marketplace. One factor in } \\
\text { pricing is uncertainty. Therefore, decreasing } \\
\text { uncertainty may be one way of improving pricing (from } \\
\text { the affordability standpoint). Is cost (of materials, } \\
\text { construction) reflected in pricing? }\end{array}$ \\
\hline mar & 1.03 & rch & $\begin{array}{l}\text { Housing market is not like others: } \\
\text { - Prices/Pricing are local } \\
\text { - Not a traditional competitive } \\
\text { market (builder is part of a } \\
\text { cartel) } \\
\text { - Benefits may not pass directly } \\
\text { to home buyer } \\
\text { - What happens to industry as a } \\
\text { result of innovation? }\end{array}$ & $\begin{array}{l}\text { The housing market is not free. It is not fully } \\
\text { competitive because it depends on land availability and } \\
\text { zoning. Therefore, if an innovation is introduced that } \\
\text { should reduce costs over time, the market may not } \\
\text { respond. Housing prices are set by location decisions } \\
\text { about square footage, acreage, and local regulations. } \\
\text { There are constraints on this market. This is not a fully } \\
\text { competitive market. Building permits convey market } \\
\text { power ("a piece of the monopoly"). The question is not } \\
\text { whether the savings get passed on to the homebuyer, } \\
\text { because most likely they are not. So must look at what } \\
\text { the long-run impact of the innovation will be on the } \\
\text { market regardless of whether the savings get passed } \\
\text { on to the buyer. Pricing is based on the cost of } \\
\text { alternative homes in the community (comparables), not } \\
\text { the cost of materials. }\end{array}$ \\
\hline val & 1.04 & fin & $\begin{array}{l}\text { Value of housing is "what it will sell } \\
\text { for" } \\
\text { - Pretty competitive market, but } \\
\text { cost of building (production } \\
\text { does not set price) } \\
\text { - Price has little to do with }\end{array}$ & $\begin{array}{l}\text { Asking price is not related to the cost of building a } \\
\text { home. It has relatively little to do with the cost of the } \\
\text { structure compared to market demand. The value of } \\
\text { the house is what it will sell for. "Cheap" housing can } \\
\text { become very expensive, because the price has little to } \\
\text { do with the structure. The market determines the cost. }\end{array}$ \\
\hline
\end{tabular}




\begin{tabular}{|c|c|c|c|c|}
\hline 产 & 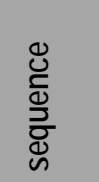 & 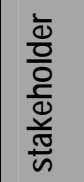 & 'flip chart' record & NIST notes \\
\hline & & & $\begin{array}{l}\text { structure } \\
\text { - Is affordability the "ability to } \\
\text { pay" or the "cost to build" }\end{array}$ & \\
\hline met & 1.05 & fin & $\begin{array}{l}\text { There are indirect relationships } \\
\text { between the cost of production and } \\
\text { the supply of housing }\end{array}$ & $\begin{array}{l}\text { Cost of materials is related to the price of the house } \\
\text { because the going level affects how much gets built } \\
\text { (supply of housing). The cost of building a house } \\
\text { determines if the house gets built or not. The market } \\
\text { defines where we go. }\end{array}$ \\
\hline val & 1.06 & rch & $\begin{array}{l}\text { Homebuilders must compete by } \\
\text { adding value }\end{array}$ & $\begin{array}{l}\text { Would like to see builders competing on quality, rather } \\
\text { than on first cost, that is, based on the value of the } \\
\text { house rather than its first cost. We are trying to get } \\
\text { from first costs to LCC. When first costs are } \\
\text { decreased, LCC are higher and consumers bear the } \\
\text { burden of this increase. }\end{array}$ \\
\hline val & 1.07 & own & $\begin{array}{l}\text { Cost will determine whether it is } \\
\text { built }\end{array}$ & $\begin{array}{l}\text { In the suburban Maryland community of Montgomery } \\
\text { Village, there is a requirement that a builder seeking a } \\
\text { permit must devote } 20 \% \text { of the construction to } \\
\text { affordable housing. The county definition of affordable } \\
\text { housing is based on the rent or purchase price of the } \\
\text { housing. }\end{array}$ \\
\hline met & 1.08 & bld & $\begin{array}{l}\text { As a builder, trying to shift buyer } \\
\text { emphasis from } 1 \text { st cost to life cycle } \\
\text { costs } \\
\text { NIST/HUD/regulators need to look } \\
\text { at incentives to emphasize LCC }\end{array}$ & $\begin{array}{l}\text { Need to focus on life-cycle costs. Need incentives to } \\
\text { shift from first costs to LCC. Housing is not a free } \\
\text { market. It is defined by policy, zoning, codes, etc. } \\
\text { Need to establish a baseline for durability instead of } \\
\text { focusing on first cost. Need incentives to create better } \\
\text { housing stock rather than the status quo of more } \\
\text { housing stock. Better housing stock implies lower LCC. }\end{array}$ \\
\hline mar & 1.09 & mcd & $\begin{array}{l}\text { Want to shift discussion from macro } \\
\text { to micro concerns: } \\
\text { - Anecdote of re-roofing, } \\
\text { question is not who benefits } \\
\text { but who receives full-effect? } \\
\text { - Homeowner does, but is given } \\
\text { no options/choices; upstream } \\
\text { decision makers decide. }\end{array}$ & $\begin{array}{l}\text { The question should not be who benefits from housing } \\
\text { innovation, but who receives its full effects. But the } \\
\text { choice of using or not using the innovation is not given } \\
\text { at time of home purchase. Choices are made for the } \\
\text { buyer "upstream," by the producers, not by the party } \\
\text { (the buyer) that receives the full effects. Homeowners } \\
\text { only choose the final packaging. But the producers } \\
\text { make the initial decisions about the use of advanced } \\
\text { technology and materials (such as for roofing). }\end{array}$ \\
\hline val & 1.10 & fin & $\begin{array}{l}\text { Individual choices do not effect } \\
\text { expected resale value (time horizon } \\
\text { can be critical to decision making) }\end{array}$ & $\begin{array}{l}\text { The average homeowner stays in their home about } \\
5 \text { years. The life cycle is short and affects the choices } \\
\text { of homeowners, too. The homeowner needs to see the } \\
\text { net benefit of the product. }\end{array}$ \\
\hline val & 1.101 & bld & (see notes) & $\begin{array}{l}\text { The extent this is true depends on whether use of more } \\
\text { durable components is reflected in resale price of the } \\
\text { home. }\end{array}$ \\
\hline pro & 1.102 & fin & (see notes) & Marketing for product manufacturers plays a big role. \\
\hline pro & 1.11 & bld & $\begin{array}{l}\text { Too many components/complex } \\
\text { product }\end{array}$ & $\begin{array}{l}\text { Making all these choices available would be costly for } \\
\text { the builder. }\end{array}$ \\
\hline mar & 1.12 & mcd & $\begin{array}{l}\text { We may be forced to work upstream } \\
\text { of homeowner }\end{array}$ & $\begin{array}{l}\text { We do not want to offer unlimited choices to } \\
\text { homebuyers. But there is a need to work upstream of } \\
\text { homeowner, need to understand what part of the costs } \\
\text { and benefits that these groups see. }\end{array}$ \\
\hline
\end{tabular}




\begin{tabular}{|c|c|c|c|c|}
\hline 힣 & 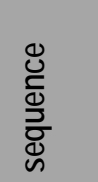 & 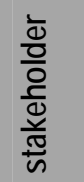 & 'flip chart' record & NIST notes \\
\hline met & 1.13 & bld & $\begin{array}{l}\text { Consider concept of 'durability } \\
\text { rating' system/policy } \\
\text { - Single number, } 0-100 \\
\text { - Market compensation of rating } \\
\text { (higher resale for higher rating) }\end{array}$ & $\begin{array}{l}\text { In a previous contract with the U.S. Forest Service, a } \\
\text { durability rating system was discussed. A policy could } \\
\text { be done by the insurance company. Every house } \\
\text { would get a number. A house rated } 80 \text { would last } \\
\text { longer than a house rated } 60 \text {. A rating of } 45 \text { would be } \\
\text { low. A house rated } 60 \text { could move up to a } 68 \text { if an } \\
\text { improvement were made to its durability. What rating } \\
\text { would be acceptable to you? Durability rating will focus } \\
\text { homeowners on looking at LCC. Homebuyers are } \\
\text { more focused on the layout of the home. To be } \\
\text { effective, the rating must mean something to the } \\
\text { consumer. Policy could play a role here, as could } \\
\text { lenders, insurers, and code inspectors. The idea is } \\
\text { consenting to durability rather than incenting to first } \\
\text { cost. }\end{array}$ \\
\hline mar & 1.14 & bld & $\begin{array}{l}\text { Consumer does not want durability, } \\
\text { consumer wants upgraded carpet } \\
\text { - Buyer is buying a complete } \\
\text { product package } \\
\text { - Builder has difficulty in } \\
\text { accommodating 'menu' of } \\
\text { product choices (especially for } \\
\text { spec building) } \\
\text { - Buyer expects minimum level } \\
\text { of durability }\end{array}$ & $\begin{array}{l}\text { The homeowner has limited choices in a new home } \\
\text { unless they have a custom home built. Most people do } \\
\text { not have the understanding to make choices. Except } \\
\text { for custom homes, the builder makes decisions about } \\
\text { the components of the home. Builders mass produce, } \\
\text { and do not want to give choices to buyers. In any case, } \\
\text { buyers care about visible quality, such as of cabinets } \\
\text { and carpeting, not the durability of structure. Most } \\
\text { people do not have the understanding to make choices. } \\
\text { NAHB are mainly custom builders. Most subdivisions } \\
\text { are not usually custom built. Need to provide better } \\
\text { information to homebuyers about the importance of } \\
\text { durability. }\end{array}$ \\
\hline met & 1.15 & $\mathrm{mcd}$ & $\begin{array}{l}\text { Go beyond durability. Consider } \\
\text { series of scales/indexes with } \\
\text { differing parameters. }\end{array}$ & $\begin{array}{l}\text { If there were a validated index to let the buyer know the } \\
\text { durability and this were seen in the price, then if buyers } \\
\text { make their purchase decisions based on this } \\
\text { information, then would durability become more } \\
\text { important in the marketplace? }\end{array}$ \\
\hline met & 1.151 & bld & (see notes) & $\begin{array}{l}\text { The index would be difficult to develop. And it would } \\
\text { have to be credible and meaningful to the homebuyer. } \\
\text { Sometimes, the buyers do not make the "right" } \\
\text { decision, even with information. It is difficult to predict } \\
\text { this behavior. }\end{array}$ \\
\hline met & 1.16 & reg & $\begin{array}{l}\text { Folks are working on this/these } \\
\text { ideas now. }\end{array}$ & $\begin{array}{l}\text { The Leadership in Energy and Environmental Design } \\
\text { (LEED) group already doing this, i.e., evaluating } \\
\text { products based on LCC, not first cost. }\end{array}$ \\
\hline met & 1.17 & $\mathrm{mcd}$ & $\begin{array}{l}\text { Resignation to "the system is the } \\
\text { system" will not work }\end{array}$ & The index would be very complex. \\
\hline met & 1.18 & rch & $\begin{array}{l}\text { May interest consumer in concern } \\
\text { about the } 1^{\text {st }} \text { resale period, but not } \\
\text { the } 15^{\text {th }} \text { cycle } \\
\text { Builders are concerned with } \\
\text { contemporary tastes }\end{array}$ & $\begin{array}{l}\text { The time an asset is held will determine its value. } \\
\text { Everyone considers the short run. No one is going to } \\
\text { focus on LCC currently, with rising real income levels. } \\
\text { The concern is with the } 1 \text { st and } 2 \text { nd resale, but not the } \\
15 \text { th resale. Buyers ask questions such as, "Do I have } \\
\text { the most current bathroom or kitchen?" Buyers care }\end{array}$ \\
\hline
\end{tabular}




\begin{tabular}{|c|c|c|c|c|}
\hline 产 & 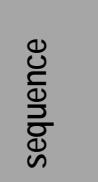 & 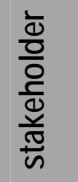 & 'flip chart' record & NIST notes \\
\hline & & & & $\begin{array}{l}\text { about aesthetics, floor plan, and curb appeal. Who } \\
\text { cares about durability? }\end{array}$ \\
\hline seg & 1.19 & rch & $\begin{array}{l}\text { Homeowners are not a } \\
\text { homogenous group; } 2^{\text {nd }} \text { time buyers } \\
\text { have much different interests than } \\
\text { 1st timers }\end{array}$ & $\begin{array}{l}\text { There is diversity among buyers. There is a huge } \\
\text { difference between concerns for } 1 \text { st-time homebuyers } \\
\text { and } 2 \text { nd time buyers. According to a survey, } 1 \text { st time } \\
\text { homebuyers look at first cost and location. Second-time } \\
\text { homebuyers, however, pay more attention to long-term } \\
\text { durability because of the experiences they may have } \\
\text { had with their first home. Realtors and appraisers need } \\
\text { to bring these issues into their discussions. }\end{array}$ \\
\hline att & 1.20 & reg & $\begin{array}{l}\text { Community } \quad \text { interests } \text { must be } \\
\text { considered; long-term interests } \\
\text { matter to lenders. }\end{array}$ & $\begin{array}{l}\text { There is also a community interest in durability and } \\
\text { what causes widespread adoption of innovations. } \\
\text { Homes that do not perform become vacant. }\end{array}$ \\
\hline att & 1.201 & fin & (see notes) & Financiers also have a stake. \\
\hline att & 1.202 & rch & (see notes) & $\begin{array}{l}\text { Real estate professionals and appraisers must be } \\
\text { included because they affect the price of the house. }\end{array}$ \\
\hline val & 1.21 & bld & $\begin{array}{l}\text { Appraised value is a blunt } \\
\text { instrument and should be more } \\
\text { sensitive. }\end{array}$ & (see record) \\
\hline bar & 1.22 & $\mathrm{mcd}$ & $\begin{array}{l}\text { Buyers are not getting information } \\
\text { related to their own interests }\end{array}$ & (see record) \\
\hline bar & 1.221 & reg & (see notes) & $\begin{array}{l}\text { The long term begins on day } 1 \text {. Therefore, even if they } \\
\text { ignore resale value, can still make the point about } \\
\text { buyer and owner self interest. }\end{array}$ \\
\hline bar & 1.23 & fin & $\begin{array}{l}\text { Buyers would consider information if } \\
\text { informed }\end{array}$ & $\begin{array}{l}\text { If buyers knew durability affected the underwriting } \\
\text { decision, durability would matter to them. An example } \\
\text { is energy-efficient mortgages. }\end{array}$ \\
\hline bar & 1.24 & rch & $\begin{array}{l}\text { Contrary evidence-energy } \\
\text { mortgage has not taken off } \\
\text { The basic question of who benefits } \\
\text { needs to be modified }\end{array}$ & $\begin{array}{l}\text { But energy-efficient mortgages have not taken off and } \\
\text { are not widely accepted, even } 15 \text { years after their } \\
\text { introduction. }\end{array}$ \\
\hline bar & 1.241 & rch & (see notes) & The lesson to be drawn is to look at why. \\
\hline bar & 1.242 & rch & (see notes) & $\begin{array}{l}\text { The reasons are too complex to be addressed here. } \\
\text { The questions to be asked must be, what will the } \\
\text { benefits of the innovation be and who will benefit? If an } \\
\text { innovation becomes widespread practice, what are its } \\
\text { impacts? You cannot answer the question on } \\
\text { affordability unless you know in whose mind. } \\
\text { Perception changes for the 1st time homebuyer }\end{array}$ \\
\hline att & 1.25 & mcd & $\begin{array}{l}\text { Which effects/parameters should be } \\
\text { emphasized? }\end{array}$ & $\begin{array}{l}\text { Which characteristics of the house purchase are most } \\
\text { important in a homeowner's or home-buyer's judgment } \\
\text { that the home is affordable? This may reflect a matter } \\
\text { of value received for money spent, transparency of the } \\
\text { cost as part of total cost, or the individual's personal } \\
\text { involvement in the decision to accept this characteristic. } \\
\text { Which parties will benefit or be affected affects whether } \\
\text { the innovation will be available to others. }\end{array}$ \\
\hline bar & 1.26 & cst & $\begin{array}{l}\text { The important issue is who } \\
\text { decides-don't understand what is } \\
\text { meant by 'affordability' }\end{array}$ & $\begin{array}{l}\text { This is driven by stakeholders. One example was the } \\
\text { requirement that all homes in one area be all electric. } \\
\text { This was a disaster. Cannot sell the consumer short. It }\end{array}$ \\
\hline
\end{tabular}




\begin{tabular}{|c|c|c|c|c|}
\hline 离 & 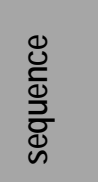 & 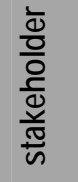 & 'flip chart' record & NIST notes \\
\hline & & & $\begin{array}{l}\text { - What are policies that affect } \\
\text { affordability, that affect } \\
\text { homebuyer and other } \\
\text { perceptions? } \\
\text { - How do you get information to } \\
\text { consumers? }\end{array}$ & is LCC. They just need the information. \\
\hline att & 1.27 & fin & $\begin{array}{l}\text { Biggest problem is functional } \\
\text { obsolescence } \\
\text { - Build in flexibility to change } \\
\text { - Today will not be tomorrow in } \\
\text { all dimensions, including } \\
\text { operating cost concerns }\end{array}$ & $\begin{array}{l}\text { Flexibility of housing design is important. The big } \\
\text { problem is not structural deterioration of a home. It is } \\
\text { functional obsolescence. Therefore, need to build } \\
\text { flexibility into the house and its design for future } \\
\text { changes, including those not motivated by operating } \\
\text { costs. }\end{array}$ \\
\hline mar & 1.28 & bld & $\begin{array}{l}\text { Why would builder be interested in } \\
\text { putting in new stuff? } \\
\text { Homeowners are at risk, should } \\
\text { they also be "accountable"? }\end{array}$ & $\begin{array}{l}\text { There is resistance to innovation, including among } \\
\text { builders and renovators. Homeowners need to be held } \\
\text { accountable for their maintenance actions and } \\
\text { decisions. They need to clean gutters and maintain the } \\
\text { home, not just components. Homeowner responsibility } \\
\text { would be enhanced with a durability rating because this } \\
\text { responsibility would be rewarded by increases in the } \\
\text { durability rating, and therefore the market value. We } \\
\text { need flexibility to change. What is attractive today may } \\
\text { not be attractive tomorrow. Why would the builder want } \\
\text { to put something in? The homeowner has a role in } \\
\text { durability and needs knowledge and information about } \\
\text { it. }\end{array}$ \\
\hline att & 1.29 & rch & $\begin{array}{l}\text { 'Affordability' is whatever } \\
\text { FNMA/Freddie Mac say it is (PITI) }\end{array}$ & $\begin{array}{l}\text { The extent and quality of maintenance is already } \\
\text { captured in the resale value of the home. The } \\
\text { homeowner is a liable party. The starting point of the } \\
\text { affordability question is that it is based on whether } \\
\text { Fannie or Freddie says it is affordable, i.e., can you } \\
\text { qualify for the mortgage? }\end{array}$ \\
\hline att & 1.291 & mcd & (see notes) & $\begin{array}{l}\text { The buyers define what is affordable. Fannie and } \\
\text { Freddie are secondary players. Buyer perceptions } \\
\text { define affordability. The question is, what drives those } \\
\text { perceptions? }\end{array}$ \\
\hline mar & 1.30 & fin & $\begin{array}{l}\text { Innovation in lending has led to } \\
\text { greater purchasing power }\end{array}$ & $\begin{array}{l}\text { The most significant factor improving affordability of } \\
\text { housing has been automated underwriting. Just a few } \\
\text { years ago, closing costs on a house averaged } 2 \frac{1}{2} \\
\text { points. Now, they represent } 1 / 2 \text { point, on average. } \\
\text { Innovations in financing have had the biggest impact on } \\
\text { affordability. }\end{array}$ \\
\hline att & 1.301 & mcd & (see notes) & $\begin{array}{l}\text { A house is affordable from the homeowner's } \\
\text { perspective. }\end{array}$ \\
\hline att & 1.31 & cst & $\begin{array}{l}\text { Durability measurement has been } \\
\text { supported by component } \\
\text { manufacturers, opposed by } \\
\text { materials suppliers, and opposed by } \\
\text { builders (because already factored } \\
\text { into markets) }\end{array}$ & $\begin{array}{l}\text { The market is having trouble swallowing guidelines } \\
\text { such as durability ratings. Who supported the durability } \\
\text { standard at ASTM? The components manufacturers. } \\
\text { Who didn't? The raw materials suppliers, including } \\
\text { gypsum producers, assemblers, and builders. These } \\
\text { groups argued that the market already values } \\
\text { durability, and therefore do not need more information. }\end{array}$ \\
\hline
\end{tabular}




\begin{tabular}{|c|c|c|c|c|}
\hline 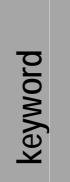 & 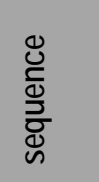 & $\begin{array}{l}\frac{\overline{0}}{0} \\
\frac{0}{0} \\
\frac{\bar{c}}{\omega}\end{array}$ & 'flip chart' record & NIST notes \\
\hline & & & & $\begin{array}{l}\text { There is a need to measure the performance of the } \\
\text { house. }\end{array}$ \\
\hline met & 1.32 & mcd & $\begin{array}{l}\text { Uncertainty is the issue with } \\
\text { performance measures } \\
\text { - Want to align 'who decides' } \\
\text { with 'who decides what the } \\
\text { benefits will be' } \\
\text { - Various stakeholders/decision- } \\
\text { makers come in a different } \\
\text { points with different interests }\end{array}$ & $\begin{array}{l}\text { Regarding the earlier point about homeowner } \\
\text { responsibility, as the ceiling is lowered, the floor is } \\
\text { raised. It is important to align the benefits and } \\
\text { consequences of choices with those that make the } \\
\text { choices. In my case, labor poorly installed my shingles, } \\
\text { but I, the homeowner, had to bear the consequences of } \\
\text { that poor installation. There is no way to track certain } \\
\text { points on the development chain, such as } \\
\text { workmanship, that have a great effect on value. There } \\
\text { are some checks on this: unions, liability concerns. } \\
\text { The status quo is a sequential decision-making } \\
\text { process. When a buyer comes into the process, he } \\
\text { sees some but not all of the consequences of the } \\
\text { previous decisions. There is no sword that cuts } \\
\text { through the Gordian knots. Must leverage each } \\
\text { decision node in the process. Some innovations lead } \\
\text { to high expectations. Who determines the benefit? } \\
\text { The people receiving the benefits (and costs) SHOULD } \\
\text { be the ones making the choices (but aren't always). }\end{array}$ \\
\hline per & 1.33 & $\mathrm{mcd}$ & $\begin{array}{l}\text { Who (are stakeholders) and why: } \\
\text { - Labor unions--jobs } \\
\text { - } \quad \text { Testing labs--money, jobs, } \\
\text { uncertainty, liability } \\
\text { - Investors--money, liability } \\
\text { - } \quad \text { Political jurisdictions-- } \\
\text { constituent service }\end{array}$ & $\begin{array}{l}\text { Regarding innovations, some groups have stakes. } \\
\text { There are many people who do not want to see certain } \\
\text { innovations implemented for various reasons, such as } \\
\text { lower revenue. For labor unions, at stake are jobs, } \\
\text { compensation, and liability. For the conformity } \\
\text { assessment community (quality testing and } \\
\text { performance testing labs), the stakes are payments for } \\
\text { services and jobs. For investors and venture } \\
\text { capitalists, the stake is money. All groups are incented } \\
\text { by money, some also have liability concerns, too. In } \\
\text { addition to these groups, the stake of realtors and } \\
\text { appraisers is money. For government, it is setting } \\
\text { policy and doing right by its citizens. }\end{array}$ \\
\hline per & 1.331 & mcd & (see notes) & $\begin{array}{l}\text { Add to the testing labs' stake uncertainty and liability } \\
\text { because of difficulty of designing a test to accurately } \\
\text { predict performance in realistic situations. }\end{array}$ \\
\hline per & 1.332 & mcd & (see notes) & $\begin{array}{l}\text { Being first is costly. Labs will charge higher testing } \\
\text { fees to test a product that is extremely novel and is } \\
\text { dissimilar to what is already out there. }\end{array}$ \\
\hline per & 1.333 & $\mathrm{mcd}$ & (see notes) & If it is willing to do the test at all. \\
\hline att & 1.34 & own & $\begin{array}{l}\text { Innovation is an invention that } \\
\text { succeeds in the marketplace; no } \\
\text { success-no innovation }\end{array}$ & $\begin{array}{l}\text { The definition of innovation is an invention that } \\
\text { succeeds in the marketplace. What ensures its } \\
\text { success? Innovation will only occur if people perceive } \\
\text { a priori benefit. }\end{array}$ \\
\hline seg & 1.35 & own & $\begin{array}{l}\text { Low-income buyer is a different } \\
\text { market; must balance: } \\
\text { - Current social taste } \\
\text { - Income limits } \\
\text { - Performance of home }\end{array}$ & $\begin{array}{l}\text { The constraints in purchasing decisions are: style; first } \\
\text { cost (X\% of median income as defined by Fannie and } \\
\text { Freddie); performance of home (no high maintenance } \\
\text { requirements, no time bombs). For low-income } \\
\text { homebuyers, the life cycle is much longer, about } 10\end{array}$ \\
\hline
\end{tabular}




\begin{tabular}{|c|c|c|c|c|}
\hline 产 & 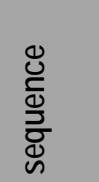 & 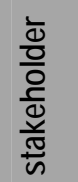 & 'flip chart' record & NIST notes \\
\hline & & & $\begin{array}{l}\text { Tradeoffs must be made and high } \\
\text { maintenance is a key issue }\end{array}$ & $\begin{array}{l}\text { years to } 15 \text { years, because they do not move as often. } \\
\text { What is acceptable for the lower-income buyer is the } \\
\text { first thing to consider. First costs are the second } \\
\text { consideration, and the performance of the home is } \\
\text { third. Durability is more important to this group } \\
\text { because they do not move and they may not be able to } \\
\text { afford expensive maintenance expenses such as } \\
\text { replacing a roof. Energy efficiency matters, too. But } \\
\text { first cost is also very important. }\end{array}$ \\
\hline mar & 1.36 & own & $\begin{array}{l}\text { For low-income, a } 3^{\text {rd }} \text { party has } \\
\text { joined the transaction and regulates } \\
\text { decision-making; not present in the } \\
\text { private-sector commercial market }\end{array}$ & $\begin{array}{l}\text { The non-profit building sector that the previous speaker } \\
\text { represents cares about the interest of the homebuyers. } \\
\text { In the for-profit market, we do not see this. }\end{array}$ \\
\hline mar & 1.361 & own & (see notes) & $\begin{array}{l}\text { The non-profit builders make decisions in the interest of } \\
\text { the homebuyers. }\end{array}$ \\
\hline per & 1.37 & rch & $\begin{array}{l}\text { Appraisers and realtors are very } \\
\text { important in private market }\end{array}$ & $\begin{array}{l}\text { Another problem is that appraisers do not have } \\
\text { sufficient technical knowledge or do not have } \\
\text { comparables to value some improvements. }\end{array}$ \\
\hline bar & 1.38 & mcd & $\begin{array}{l}\text { Suggest "dynamic constrained } \\
\text { optimization" } \\
\text { We need actions to reduce } \\
\text { constraints and/or } \\
\text { constraints }\end{array}$ & $\begin{array}{l}\text { We need to set the problem up as a dynamic } \\
\text { constrained optimization. What now happens is that } \\
\text { the first cost is either the objective to be minimized, or it } \\
\text { is a constraint that is so restrictive as to make other } \\
\text { choices moot. Need something to reduce the } \\
\text { constraining effect of first cost, so that life-cycle costs } \\
\text { are the true objectives. }\end{array}$ \\
\hline met & 1.381 & rch & (see notes) & $\begin{array}{l}\text { Life-cycle costs are a function of the study period. } \\
\text { Need to include first costs. Durability to a homebuilder } \\
\text { is a shorter time period than a homeowner. There is a } \\
\text { LCC for each, but the time horizon is just increased or } \\
\text { decreased. In my experience, trades people and } \\
\text { technicians, even those with little formal education, are } \\
\text { savvy about LCC. They know that you would not put } \\
\text { the same products into a house that you rent out } \\
\text { compared to a house that you live in (example about } \\
\text { heat pump). }\end{array}$ \\
\hline bar & 1.382 & rch & (see notes) & $\begin{array}{l}\text { The contrast between the for-profit and non-profit } \\
\text { builders is too stark. For speculative builders, the time } \\
\text { horizon is shorter. But they care about what they build } \\
\text { to the extent that they want to avoid callbacks and } \\
\text { liability. Their time horizon may be about } 5 \text { years } \\
\text { (maybe ten in California). The question is, how can the } \\
\text { time horizon of for-profit builders be extended beyond } \\
\text { these } 5 \text { years to } 10 \text { years? Right now, ambulance } \\
\text { chasers are having this effect. They are forcing } \\
\text { builders to confront durability in a way not done a few } \\
\text { years ago, and to choose "tried and true" materials. } \\
\text { The effect is for the builders to not choose the cheapest } \\
\text { products, but also not to choose the most innovative } \\
\text { products, either. }\end{array}$ \\
\hline bar & 1.39 & cst & Is the financing of the first buyer (of & Is the financing for the first buyer of the innovation an \\
\hline
\end{tabular}




\begin{tabular}{|c|c|c|c|c|}
\hline 产 & 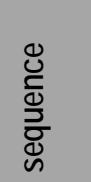 & 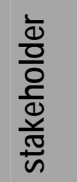 & 'flip chart' record & NIST notes \\
\hline & & & $\begin{array}{l}\text { innovation) an opportunity } \\
\text { incentives? }\end{array}$ & opportunity for incentives? \\
\hline met & 1.391 & rch & (see notes) & $\begin{array}{l}\text { How would durability be converted into underwriting } \\
\text { criteria? To take an example, energy is quantifiable, } \\
\text { but in spite of this, it is not included. Durability would } \\
\text { be even more difficult to quantify. }\end{array}$ \\
\hline val & 1.40 & fin & $\begin{array}{l}\text { If it is worth something, lenders will } \\
\text { underwrite it. }\end{array}$ & $\begin{array}{l}\text { The market will price durability. Lenders will not } \\
\text { because it is not part of the (lending) price. } \\
\text { Underwriting for single-family homes depends on the } \\
\text { ability to repay the loan. }\end{array}$ \\
\hline seg & 1.41 & rch & $\begin{array}{l}\text { Maybe rating system is more } \\
\text { suitable/appropriate for 'existing } \\
\text { stock; } 1 \text { st buyers are the least } \\
\text { constrained segment }\end{array}$ & $\begin{array}{l}\text { The rating system can fill the information gap and start } \\
\text { the process. }\end{array}$ \\
\hline mar & 1.42 & mcd & $\begin{array}{l}\text { Diffusion of innovation-later } \\
\text { adopters are less risk tolerant }\end{array}$ & $\begin{array}{l}\text { Certain types of buyers prefer innovation. These early } \\
\text { adopters accept the risks and all the other aspects of } \\
\text { being first. But this is pushing to a risk averse, more } \\
\text { conservative agenda. Innovation may not be targeted } \\
\text { to new construction, but for rehabilitation of older } \\
\text { homes. }\end{array}$ \\
\hline att & 1.43 & own & $\begin{array}{l}\text { Community concerns should be } \\
\text { considered; they may be the } \\
\text { ultimate benefactor }\end{array}$ & $\begin{array}{l}\text { What about the effect of durability on the community? } \\
\text { Benefits to the community are worth considering } \\
\text { heavily when deciding the method by which to build. } \\
\text { More durable housing benefits the community, because } \\
\text { it lasts longer and retains value. }\end{array}$ \\
\hline bar & 1.44 & bld & $\begin{array}{l}\text { Regulation is the key (represents } \\
30 \% \text { of the cost of housing) } \\
\text { - Recognize that existing stock } \\
\text { dwarfs new construction } \\
\text { (replacement is } 2 \% \text { to } 4 \% \text { per } \\
\text { year) } \\
\text { Recognize that delivery } \\
\text { systems for innovation in new } \\
\text { and existing housing are very } \\
\text { different }\end{array}$ & $\begin{array}{l}\text { Regulation accounts for } 30 \% \text { of the cost of housing. } \\
\text { Regulation drives a lot of the first cost. These numbers } \\
\text { are from the Kemp Commission Report. }\end{array}$ \\
\hline bar & 1.45 & bld & (see notes) & Land availability and regulations do drive costs. \\
\hline bar & 1.46 & bld & (see notes) & $\begin{array}{l}\text { A second point is that the existing housing stock dwarfs } \\
\text { new stock. These older homes are not going away. } \\
\text { They are just getting older. Even replacing } 2 \% \text { to } 3 \% \\
\text { of this stock annually means that these houses will be } \\
\text { around in } 20 \text { years, } 30 \text { years, } 40 \text { years, even } 60 \text { years } \\
\text { from now. How can we extend the dynamic } \\
\text { constrained optimization to } 60 \text { years? Other } \\
\text { considerations are that the average age of a house } \\
\text { remodeler is } 47 \text {, and the average person working in } \\
\text { construction is not U.S. born. }\end{array}$ \\
\hline
\end{tabular}




\section{Discussion session \#2: How to "push" innovation benefits to the homeowner, at the}

scale of housing components? How can we help the homebuyer to see the big picture, e.g., benefits as well as costs, especially initial costs? If a benefit comes at added cost, can the homeowner trade it off against reduced performance somewhere else in the house? Is the production function of housing (the current delivery system) flexible in that way to allow for substitutions among component costs, or is every innovation an "extra expense"?

\begin{tabular}{|c|c|c|c|c|}
\hline 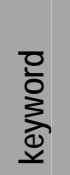 & 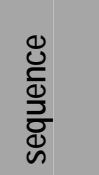 & 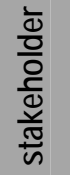 & 'flip chart' record & NIST notes \\
\hline mar & 2.01 & mfr & $\begin{array}{l}\text { Not 'push'; identify where 'pull' is } \\
\text { from and address need; use multiple } \\
\text { channels to reach consumer }\end{array}$ & $\begin{array}{l}\text { 1. Innovation cannot be "pushed." It is necessary to } \\
\text { understand where the flaws and core values exist } \\
\text { to motivate innovation. "If it ain't broke, don't fix } \\
\text { it." Have to identify and act upon and address a } \\
\text { "pull." Must demonstrate that the product satisfies } \\
\text { a need. } \\
\text { 2. How to communicate with homeowners? Who } \\
\text { touches homeowners? Real estate agents, the } \\
\text { Internet, advertising, newspaper articles (popular } \\
\text { press). Must use these means to disseminate } \\
\text { information to homeowners. }\end{array}$ \\
\hline val & 2.02 & bld & $\begin{array}{l}\text { Must have a benefit to sell to } \\
\text { customer (builder typically) } \\
\text { Cannot trade off performance from } \\
\text { one system to another } \\
\text { Must create value for builder or } \\
\text { homeowner }\end{array}$ & $\begin{array}{l}\text { Agree that innovation benefits cannot be "pushed" on } \\
\text { the consumer. It is necessary to fill a place for } \\
\text { demand. "Push" is a mistake. The adoption of OSB } \\
\text { (oriented strand board) and l-joists, for example, are } \\
\text { done through the builder, by providing lower installation } \\
\text { costs, better performance, more durability, other cost } \\
\text { benefits. Innovations must provide some value to the } \\
\text { homebuilder and homeowner. Trade-offs are possible } \\
\text { only in energy performance codes. }\end{array}$ \\
\hline mar & 2.03 & cst & $\begin{array}{l}\text { How do you identify 'pull' rather than } \\
\text { 'push'? }\end{array}$ & (see record) \\
\hline val & 2.04 & bld & $\begin{array}{l}\text { Must have some sought after benefit } \\
\text { for consumer (builder) }\end{array}$ & (see record) \\
\hline bar & 2.041 & cst & (see notes) & Sprinklers in multifamily homes are now required. \\
\hline mar & 2.042 & mcd & (see notes) & Must help the homeowners appreciate the benefits. \\
\hline mar & 2.043 & own & (see notes) & $\begin{array}{l}\text { Advertisements for homes do not provide detailed } \\
\text { information about windows, use of I-joists, etc. that are } \\
\text { used. They focus on the price of the homes and their } \\
\text { beauty. }\end{array}$ \\
\hline mar & 2.044 & bld & (see notes) & $\begin{array}{l}\text { Realtors only care about square footage and street } \\
\text { address. People will pay for self-cleaning (stain- } \\
\text { resistant) carpets, but energy efficient renovations did } \\
\text { not pay back. }\end{array}$ \\
\hline att & 2.05 & own & $\begin{array}{l}\text { Builder will emphasize touch and } \\
\text { feel qualities of product }\end{array}$ & $\begin{array}{l}\text { In most housing ads, houses are sold by things that } \\
\text { can be "touched," e.g. cabinets. Things like kitchens, } \\
\text { bathrooms, decks, basement, fireplace get some (but } \\
\text { less than } 100 \% \text { ) payback. These are all "touch and } \\
\text { see" items. Others that are not visible or not } \\
\text { appreciated as necessary do not get paid back. }\end{array}$ \\
\hline
\end{tabular}




\begin{tabular}{|c|c|c|c|c|}
\hline 文 & 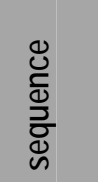 & $\begin{array}{l}\frac{\overline{0}}{0} \\
\frac{0}{0} \\
\frac{\bar{c}}{\omega}\end{array}$ & 'flip chart' record & NIST notes \\
\hline val & 2.06 & bld & $\begin{array}{l}\text { Case study: warm climate retrofit of } \\
\text { tract home c.' } 85 \text {; cut energy costs } \\
\text { by } 40 \% \text {, spent } 30 \% \text { extra, got } \\
\text { same price as next door on resale. }\end{array}$ & $\begin{array}{l}\text { Realtors only care about square footage and street } \\
\text { address. People will pay for self-cleaning carpet, not } \\
\text { greater energy efficiency. }\end{array}$ \\
\hline bar & 2.07 & own & Never recover total costs. & (see record) \\
\hline bar & 2.08 & bld & $\begin{array}{l}\text { May not get a nickel of initial costs } \\
\text { back }\end{array}$ & (see record) \\
\hline att & 2.09 & mcd & $\begin{array}{l}\text { Are we just left with answering the } \\
\text { question of whether production } \\
\text { process allows substitution among } \\
\text { components? }\end{array}$ & We should focus on the third question, that of tradeoffs. \\
\hline bar & 2.10 & rch & $\begin{array}{l}\text { Consumer is responding in certain } \\
\text { areas to energy star home as a } \\
\text { marketing tool-first instance of } \\
\text { label having an impact in housing } \\
\text { markets }\end{array}$ & $\begin{array}{l}\text { Builders in some cities have had success with the } \\
\text { energy-star labeled home, especially those with } \\
\text { younger populations in the far west (granola crowd). } \\
\text { This is the first successful attempt where a } \\
\text { performance label is having an effect, even if it is only } \\
\text { to a certain segment of the population. Why was it } \\
\text { successful? }\end{array}$ \\
\hline bar & 2.101 & man & (see notes) & Safety and protection are automatic pulls. \\
\hline bar & 2.102 & own & (see notes) & $\begin{array}{l}\text { People assume that the codes have it covered. They } \\
\text { trust the status quo. }\end{array}$ \\
\hline bar & 2.103 & cst & (see notes) & $\begin{array}{l}\text { [elaborated on the notion of tradeoffs as he intended } \\
\text { the question when writing it.] }\end{array}$ \\
\hline bar & 2.104 & $\begin{array}{l}\text { rch, } \\
\text { bld }\end{array}$ & (see notes) & No, that tradeoff cannot be done. \\
\hline del & 2.11 & bld & Some choices may be allowed. & $\begin{array}{l}\text { All builders want to be seen as custom. But in truth, } \\
\text { most builders will only offer limited choices. But these } \\
\text { choices tend to be about cosmetic attributes, such as } \\
\text { counter tops, rather than long-run, performance- } \\
\text { enhancing elements. }\end{array}$ \\
\hline del & 2.12 & mcd & $\begin{array}{l}\text { What about improved design, } \\
\text { equivalent performance, and } \\
\text { innovation? Is delivery system } \\
\text { capable of flexibility? }\end{array}$ & $\begin{array}{l}\text { Homebuyers want home designs to be innovative and } \\
\text { homebuilders to include innovative products without } \\
\text { increasing the price. How do we get these innovative } \\
\text { products out there? }\end{array}$ \\
\hline met & 2.13 & bld & $\begin{array}{l}\text { As a rule-of-thumb, builder may } \\
\text { want to price at } 80 \% \text { of buyer's } \\
\text { budget, then add unforeseens, and } \\
\text { widgets that are wanted (product } \\
\text { 'pull') }\end{array}$ & $\begin{array}{l}\text { The way I deal with my clients and give them choices is } \\
\text { this: I ask my clients what their budget is, and I offer } \\
\text { them something for } 80 \% \text { of their budget. This cushion } \\
\text { allows for things like uncertainty in costs, upgrades, } \\
\text { etc. Most of the upgrades that my clients opt for, } \\
\text { however, are for widgets, such as sound systems, } \\
\text { appliances, central HVAC. }\end{array}$ \\
\hline att & 2.14 & own & Buyer wants only see and feel stuff & $\begin{array}{l}\text { Higher income buyers will buy more durable products } \\
\text { because they look higher quality. People will upgrade } \\
\text { in things that they can physically perceive as being } \\
\text { better. Higher income people buy higher quality items. }\end{array}$ \\
\hline att & 2.15 & rch & $\begin{array}{l}\text { Disagree that structural system } \\
\text { cannot be changed }\end{array}$ & $\begin{array}{l}\text { It depends on the product whether it gets adopted even } \\
\text { if it is not observable to the buyer. For example, } \\
\text { engineered lumber vs. conventional lumber, or OSB vs. } \\
\text { plywood. Some of the decisions are not made by the }\end{array}$ \\
\hline
\end{tabular}




\begin{tabular}{|c|c|c|c|c|}
\hline 离 & 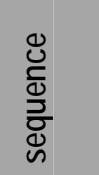 & 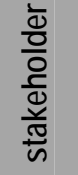 & 'flip chart' record & NIST notes \\
\hline & & & & homebuyer. \\
\hline bar & 2.16 & bld & $\begin{array}{l}\text { How do you introduce efficiencies } \\
\text { into product delivery system: } \\
\text { - } 70 \text { s-tools } \\
\text { - } 80 \text { s-hard products/pre-cut } \\
\text { studs, dimensional shingles } \\
\text { - } 90 \text { s--technology } \\
\text { - } 00 \text { s-QC management/ } \\
\text { business systems } \\
\text { Non-building considerations lead in } \\
\text { importance today; } 70 \% \\
\text { tradesmen have no employees }\end{array}$ & $\begin{array}{l}\text { This is how I see, very roughly and very generally, the } \\
\text { recent history of innovations in the housing industry. In } \\
\text { the } 1970 \text { s, there were innovations in the tools and } \\
\text { equipment used in construction. The 1980s saw } \\
\text { innovations in hard products, such as pre-cut studs, } \\
\text { OSB, and dimensional shingles. The 1990s saw } \\
\text { innovations in information and communications } \\
\text { technology, with the use of the internet and cell } \\
\text { phones. I predict that in the 2000s, the key innovations } \\
\text { will be in business systems, organization, structure, } \\
\text { management, and quality control. Only the big public } \\
\text { companies will pay attention to management, because } \\
\text { most construction companies are one-man shops with } \\
\text { no employees and therefore no management needs. } \\
\text { As an industry, we have a group that is not business } \\
\text { savvy. We need to make the tradesmen more efficient. }\end{array}$ \\
\hline bar & 2.161 & rch & (see notes) & $\begin{array}{l}\text { Or the innovation could be, as was earlier mentioned, } \\
\text { in engineered systems. }\end{array}$ \\
\hline bar & 2.162 & rch & (see notes) & $\begin{array}{l}\text { Improvements in business systems can lead to } \\
\text { improvements in cycle time. But even with big outfits, } \\
\text { there are many inefficiencies and no one seems to } \\
\text { care. }\end{array}$ \\
\hline met & 2.17 & mcd & $\begin{array}{l}\text { Should we be looking at 'grouped } \\
\text { benefits'? }\end{array}$ & $\begin{array}{l}\text { Another consideration is that with sprinklers, it was } \\
\text { seen that housing density could be allowed to increase. }\end{array}$ \\
\hline val & 2.171 & own & (see notes) & $\begin{array}{l}\text { Increasing density is the source of the biggest savings. } \\
\text { Land and infrastructure are expensive. With } \\
\text { Montgomery Village, MD's } 20 \% \text { affordable housing } \\
\text { rule that someone previously mentioned, you get bonus } \\
\text { density. }\end{array}$ \\
\hline att & 2.18 & mcd & $\begin{array}{l}\text { Yes, such as impacts of distributed } \\
\text { generation, etc. Regardless of push } \\
\text { or pull, what are the effective hooks } \\
\text { for the productinnovation? Should } \\
\text { look at a menu of innovation. }\end{array}$ & $\begin{array}{l}\text { Have to identify the hooks to the consumer and builder, } \\
\text { and identify innovations. Then link the hooks to the } \\
\text { innovations. Some hooks have been power reliability } \\
\text { (loss of power is a big concern), indoor air quality (IAQ) } \\
\text { and comfort, zero or low operating costs (such as low- } \\
\text { maintenance decking), higher security, etc. }\end{array}$ \\
\hline seg & 2.19 & rch & $\begin{array}{l}\text { There are definite stages of } \\
\text { innovation/penetration/adoption } \\
\text { - How do } 2^{\text {nd }} \text { and } 3^{\text {rd }} \text { stage } \\
\text { adopters make decisions? } \\
\text { - How is decision-making } \\
\text { different from group to group? } \\
\text { O Homeowner } 2^{\text {nd }} \\
\text { stage: follow the } \\
\text { leader } \\
\text { Homebuilder } 2^{\text {nd }} \\
\text { stage: innovator is } \\
\text { eating my lunch } \\
\text { better change }\end{array}$ & $\begin{array}{l}\text { There are different stages of adopters. Some builders } \\
\text { like to play with toys. For them, it is not necessarily } \\
\text { about markets. These are the lead adopters, the risk } \\
\text { takers. For innovations to diffuse, we must pay } \\
\text { attention to the next group, which comes after the lead } \\
\text { adopters but comes before the herd. For this } \\
\text { intermediate group, what do they respond to? What do } \\
\text { we and can we know about them? For the } \\
\text { intermediate homeowner, they are the imitator. For the } \\
\text { intermediate builder, they are those who respond to the } \\
\text { competitive advantage that the early adopters get. } \\
\text { There was an NAHB/Virginia Tech study on diffusion } \\
\text { that focused mostly on the early adopters. More } \\
\text { information needs to be collected about the }\end{array}$ \\
\hline
\end{tabular}




\begin{tabular}{|c|c|c|c|c|}
\hline 힣 & 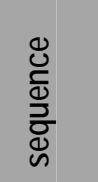 & $\begin{array}{l}\frac{\overline{0}}{0} \\
\frac{0}{0} \\
\frac{\bar{c}}{\omega}\end{array}$ & 'flip chart' record & NIST notes \\
\hline & & & & intermediate group that follows the early adopters. \\
\hline bar & 2.20 & bld & $\begin{array}{l}\text { What are 'accidental' } \\
\text { attributes/barriers to innovation? }\end{array}$ & $\begin{array}{l}\text { Some see innovations adopted by accident. For } \\
\text { example, the demand for houses on concrete slabs in } \\
\text { Phoenix. People there will not accept crawl spaces. }\end{array}$ \\
\hline att & 2.21 & bld & $\begin{array}{l}\text { Study of density health effects may } \\
\text { be a lever for higher density. May be } \\
\text { a pull factor but government must } \\
\text { lead/drive education. }\end{array}$ & $\begin{array}{l}\text { There was a New York Times article about zoning as } \\
\text { an explanation for some of the health and community } \\
\text { problems in this country. The conclusion was that if } \\
\text { zoning allowed more density and mixed-use } \\
\text { neighborhoods, people could walk more and be } \\
\text { healthier and have a greater community identification. } \\
\text { Kentlands, a planned community in Montgomery } \\
\text { County, Maryland, is an example. This could lead to } \\
\text { more sidewalks and commercial and residential areas } \\
\text { would not be segregated. This leads to less driving, } \\
\text { less obesity. } \\
\text { Health has deteriorated because of zoning. Are people } \\
\text { healthier in small towns? Could benefits like this pay for } \\
\text { innovations? }\end{array}$ \\
\hline att & 2.211 & rch & (see notes) & $\begin{array}{l}\text { Developments such as Kentlands are called the "new } \\
\text { urbanization." }\end{array}$ \\
\hline val & 2.22 & mfr & $\begin{array}{l}\text { Goal is to find the hook for the } \\
\text { consumer and innovate to the hook }\end{array}$ & $\begin{array}{l}\text { The hook in this case is the feeling of isolation, the } \\
\text { need for community. }\end{array}$ \\
\hline mar & 2.23 & rch & $\begin{array}{l}\text { 'branding' and 'bundling' may } \\
\text { stimulate demand }\end{array}$ & $\begin{array}{l}\text { There are two marketing concepts: branding and } \\
\text { bundling. Energy Star and Master Builder are brands. } \\
\text { Is there a greater willingness to pay for these brands? } \\
\text { With bundling of components and innovations, as the } \\
\text { auto industry does with the luxury package, could this } \\
\text { be a method to stimulate demand? }\end{array}$ \\
\hline bar & 2.24 & bld & $\begin{array}{l}\text { Must be somewhat cautious; be } \\
\text { careful of number of innovations } \\
\text { bundled together }\end{array}$ & $\begin{array}{l}\text { Must be careful about the number of technological } \\
\text { innovations that are shown to buyers. Most do not } \\
\text { want it. }\end{array}$ \\
\hline mar & 2.241 & mfr & (see notes) & $\begin{array}{l}\text { There is a demand for energy star products. Why has } \\
\text { Energy Star gone through an up tick recently? }\end{array}$ \\
\hline mar & 2.242 & rch & (see notes) & $\begin{array}{l}\text { One of the consultants here has worked on this with } \\
\text { the EPA recently. }\end{array}$ \\
\hline att & 2.25 & cst & $\begin{array}{l}\text { Ability to provide customization of } \\
\text { components is an advantage for } \\
\text { builders }\end{array}$ & $\begin{array}{l}\text { EPA's approach to marketing Energy Star was trial and } \\
\text { error. It began by trying to sell Energy Star using fact } \\
\text { sheets. This did not work. But when EPA began to } \\
\text { distribute information about Energy Star using CD- } \\
\text { ROMs, which is a customizable medium that builders } \\
\text { could use to choose what to compete on and put their } \\
\text { names on, the label took off. }\end{array}$ \\
\hline att & 2.26 & cst & (see notes) & $\begin{array}{l}\text { This is an example of a "push." The electronic } \\
\text { dissemination of information has become more } \\
\text { desirable. For example, a builder allowing buyers to do } \\
\text { a virtual walk-through of a model is a big push. }\end{array}$ \\
\hline att & 2.27 & bld & (see notes) & Another push is financial incentive. \\
\hline att & 2.28 & rch & (see notes) & $\begin{array}{l}\text { The problem is what is the incentive of lenders and } \\
\text { insurance companies to do this? If the benefits go to } \\
\text { the community, then the community should provide the }\end{array}$ \\
\hline
\end{tabular}




\begin{tabular}{|c|c|c|c|c|}
\hline 克 & 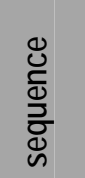 & 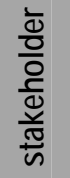 & 'flip chart' record & NIST notes \\
\hline & & & & incentives. \\
\hline att & 2.29 & mcd & (see notes) & $\begin{array}{l}\text { We need to survey the people to see what they want. } \\
\text { Packaging matters. An example is marketing light beer } \\
\text { as "less filling" rather than "less fattening." They } \\
\text { marketed not to overweight people, who would respond } \\
\text { to the second, but to people who drank a lot, who } \\
\text { respond to the first. }\end{array}$ \\
\hline att & 2.30 & bld & (see notes) & $\begin{array}{l}\text { With NAHB surveys, we have to be careful in framing } \\
\text { the questions. }\end{array}$ \\
\hline att & 2.31 & $\mathrm{mfr}$ & (see notes) & $\begin{array}{l}\text { We spend a lot on market research. We have to do } \\
\text { multiple studies and take different approaches. Market } \\
\text { research is a very creative and interpretive business } \\
\text { because most people do not know what they want. }\end{array}$ \\
\hline
\end{tabular}

\section{Discussion session \#3: How does each stakeholder view and compute life-cycle costs and benefits compared to first costs, at both scales?}

\begin{tabular}{|c|c|c|c|c|}
\hline 힣 & 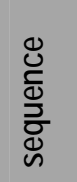 & 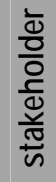 & 'flip chart' record & NIST notes \\
\hline met & 3.01 & rch & $\begin{array}{l}\text { Extending first discussion in terms } \\
\text { of stakeholders, timeframes, and } \\
\text { scales } \\
\text { Emphasize study period for LCC } \\
\text { (longer horizons introduce additional } \\
\text { concerns) } \\
\text { Stakeholder variations occur in } \\
\text { discount rate, time horizon, and } \\
\text { relevance of costs } \\
\text { LCC analysis is flexible, provides } \\
\text { structure, under a wide range of } \\
\text { conditions }\end{array}$ & $\begin{array}{l}\text { - ASTM defines LCC as: total cost of owning, caring for } \\
\text { (operating), and disposing of a building over a study } \\
\text { period. } \\
\text { - Discount rate: How do you value future benefits or } \\
\text { costs? } \\
\text { - Which costs are relevant to each stakeholder? } \\
\text { - What is the appropriate time horizon? }\end{array}$ \\
\hline met & 3.02 & bld & $\begin{array}{l}\text { Time horizons apply to builders as } \\
\text { well; builders are not opposed to } \\
\text { LCC analysis } \\
\text { Buyers are uncertain of time in } \\
\text { home, who will buy, and so use } \\
\text { varying discount rates } \\
\text { Different buyer segments behave } \\
\text { differently: } \\
\text { Higher income buyers use longer } \\
\text { time horizon } \\
\text { Lower income buyers use shorter } \\
\text { horizon (1st cost emphasis) } \\
\text { Existing owner (repeat) buyers use } \\
\text { longer horizon } \\
\text { Community wants longer horizon }\end{array}$ & $\begin{array}{l}\text { - Time horizons vary for different stakeholders. } \\
\text { - Uncertainty leads to a higher discount rate. } \\
\text { - For the homebuyer there is a tradeoff between } \\
\text { durability and aesthetics. At one time the homeowner } \\
\text { argued against life-cycle costs. The existing } \\
\text { homeowner has the same outlook as a homebuyer. } \\
\text { - High-income buyers tend to have a longer life cycle } \\
\text { horizon. Higher income people seem to have a longer } \\
\text { time horizon. } \\
\text {-A homebuilder will go by the desires of his customers. } \\
\text { How well do homebuilders perceive time horizon of } \\
\text { their customers? } \\
\text { - In finance industry, the major concern is with first } \\
\text { costs. } \\
\text { - State government is concerned with demand for }\end{array}$ \\
\hline
\end{tabular}




\begin{tabular}{|c|c|c|c|c|}
\hline 离 & 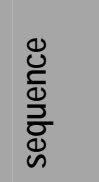 & 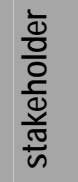 & 'flip chart' record & NIST notes \\
\hline & & & $\begin{array}{l}\text { and consideration of consequential } \\
\text { impacts } \\
\text { Builder wants to know and meet } \\
\text { customer wants (enhancing } \\
\text { reputation) } \\
\text { Product manufacturers interested in } \\
\text { long-running markets } \\
\text { Finance industry primarily interested } \\
\text { in } 1 \text { st costs; operating costs not } \\
\text { factored into lending decisions } \\
\text { Insurers have a longer horizon; want } \\
\text { to reduce future claims } \\
\text { State and local governments have a } \\
\text { longer horizon focusing on service } \\
\text { and utility impacts } \\
\text { Federal agencies emphasize long } \\
\text { term national policies, social costs, } \\
\text { and a social discount rate (e.g. OMB } \\
\text { will suggest discount rates to } \\
\text { lenders) } \\
\text { Affordability is now mentioned in the } \\
\text { IRC, previously exclusively } \\
\text { concerned with safety }\end{array}$ & $\begin{array}{l}\text { energy and water and has political concerns. } \\
\text { - Federal government has more of an interest in } \\
\text { viewing "society as a whole." The Federal } \\
\text { Government's view is on the people living in the room } \\
\text { and society as a whole. }\end{array}$ \\
\hline seg & 3.03 & fin & $\begin{array}{l}\text { Discussions have had a single } \\
\text { family emphasis while most } \\
\text { affordable housing is MF. } \\
\text { MF delivery system explicitly } \\
\text { considers age, service life, and } \\
\text { condition at resale }\end{array}$ & $\begin{array}{l}\text { Multi-family is the biggest component of affordable } \\
\text { housing. In this segment, underwriting explicitly takes } \\
\text { into account the life stage of housing. }\end{array}$ \\
\hline seg & 3.031 & bld & (see notes) & $\begin{array}{l}\text { The share of condos is } 20 \% \text {. Tax credit housing is } \\
33 \% \text {. }\end{array}$ \\
\hline per & 3.04 & mcd & $\begin{array}{l}\text { How does each stakeholder decide } \\
\text { what to consider? (Can we affect } \\
\text { the process of that decision?) } \\
\text { How are uncertainties, such as } \\
\text { hurricane, fire, etc., dealt with? How } \\
\text { are they monetized? }\end{array}$ & $\begin{array}{l}\text { Have to treat manufactured (multi-family?) homes } \\
\text { differently from single-family homes because Federal } \\
\text { regulations treat them differently. How does each } \\
\text { stakeholder determine which costs matter for their } \\
\text { decision? For occupants, it is the mortgage payment or } \\
\text { monthly rent. This is currently driven by first cost. It } \\
\text { need not be. In addition, not all maintenance is the } \\
\text { same. For example, replacing a roof is not the same } \\
\text { as fire safety or hurricane protection. Some address a } \\
\text { certain event (leaky roof) while some address uncertain } \\
\text { events (fire hazard or hurricane). Some homeowners } \\
\text { think that these uncertain events will not happen. Also } \\
\text { the risk of fatality or injury does not show up in } \\
\text { homeowner's insurance. We need to know more about } \\
\text { effective approaches in persuading homeowners to } \\
\text { factor foreseeable hazards and costs into their } \\
\text { decision-making. There are approaches with at least } \\
\text { some success with at least some audiences (e.g. } \\
\text { hurricanes in Miami). }\end{array}$ \\
\hline
\end{tabular}




\begin{tabular}{|c|c|c|c|c|}
\hline 总 & 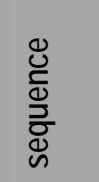 & 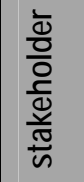 & 'flip chart' record & NIST notes \\
\hline met & 3.041 & own & (see notes) & $\begin{array}{l}\text { Right now, mortgage payments are based on first } \\
\text { costs. }\end{array}$ \\
\hline att & 3.05 & rch & $\begin{array}{l}\text { Questions will be dealt with in later } \\
\text { sessions-current research is } \\
\text { looking at parameters that are/will } \\
\text { be used. }\end{array}$ & $\begin{array}{l}\text { Issue with natural hazards shows up in insurance } \\
\text { payments, not so much in mortgage payments. These } \\
\text { issues will be addressed more fully in later sessions: } \\
\text { tomorrow's session on valuing social costs and benefits } \\
\text { and this afternoon's session on low probability events. }\end{array}$ \\
\hline seg & 3.06 & cst & $\begin{array}{l}\text { SF decision-making much different } \\
\text { than MF, which involves } 3^{\text {rd }} \text { party } \\
\text { concerns. We have not presented } \\
\text { decision-makers with policy impacts. }\end{array}$ & $\begin{array}{l}\text { Because there is political accountability, we should not } \\
\text { expect a change in the regulatory environment. The } \\
\text { distinction between single-family and multi-family is } \\
\text { important. Some standards, however, are decided not } \\
\text { at the policy level, but at the technical level, such as } \\
\text { codes. In the future, there is a need to provide } \\
\text { policymakers with choices about performance } \\
\text { standards and options about the minimums in the } \\
\text { codes. }\end{array}$ \\
\hline bar & 3.07 & rch & $\begin{array}{l}\text { Home insurance industry is not } \\
\text { responsive to efforts to get them to } \\
\text { consider incentives for durability } \\
\text { Great variation from state to state, } \\
\text { no rational relation to housing } \\
\text { quality }\end{array}$ & $\begin{array}{l}\text { The most negligent group over the last three to four } \\
\text { years has been the home insurance industry, in } \\
\text { ignoring LCC. They resist changing rates to reflect } \\
\text { construction changes. They should recognize and } \\
\text { price their product based on durability and disaster } \\
\text { resistance, but they do not. Premiums in Florida are } \\
\text { twice those in Pennsylvania. But building for safety } \\
\text { and disaster resistance does not lower the premium in } \\
\text { Florida. This is especially true now that the insurance } \\
\text { companies' stock portfolios have tanked and they are } \\
\text { more reliant on underwriting income. In response, } \\
\text { insurance companies have increased premiums. } \\
\text { Resistance to changing premiums is greatest in high } \\
\text { premium states. }\end{array}$ \\
\hline bar & 3.071 & bld & (see notes) & Do state regulations play a part in this? \\
\hline bar & 3.072 & rch & (see notes) & $\begin{array}{l}\text { No. These companies just want to make profit. They } \\
\text { will support changes in codes without data, but when it } \\
\text { comes to talking about reducing premiums, they want } \\
\text { data. }\end{array}$ \\
\hline per & 3.08 & cst & $\begin{array}{l}\text { Need to look at insurance business } \\
\text { model-loss control }\end{array}$ & (see record) \\
\hline per & 3.09 & cst & $\begin{array}{l}\text { Complex situation; insurance is } \\
\text { highly regulated for both consumer } \\
\text { and industry protection issues }\end{array}$ & State regulators are political animals. \\
\hline per & 3.091 & rch & (see notes) & $\begin{array}{l}\text { But regulators would not object if insurance companies } \\
\text { wanted to lower premiums. }\end{array}$ \\
\hline bar & 3.10 & bld & $\begin{array}{l}\text { No incentives from insurers, though } \\
\text { insurers } \quad \text { want } \quad \text { upgraded } \\
\text { performance } \\
\text { requirements. }\end{array}$ & $\begin{array}{l}\text { But any decrease would have to be balanced by an } \\
\text { increase somewhere else. More restrictive codes are } \\
\text { the easiest way for insurers to protect themselves from } \\
\text { losses. States control the insurance industry; they } \\
\text { must allow insurance companies to price on risk. State } \\
\text { Farm, for example, is a big player. It can influence the } \\
\text { marketplace. It has threatened to pull out of Texas and } \\
\text { other states because it was too exposed there. }\end{array}$ \\
\hline
\end{tabular}




\begin{tabular}{|c|c|c|c|c|}
\hline 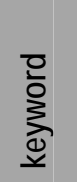 & 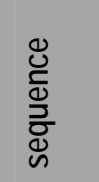 & 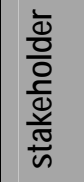 & 'flip chart' record & NIST notes \\
\hline per & 3.11 & bld & $\begin{array}{l}\text { Are regulators actually } \\
\text { stakeholders-do they have a stake } \\
\text { in housing longevity? }\end{array}$ & $\begin{array}{l}\text { Are regulators stakeholders? What is their interest? } \\
\text { Longevity? }\end{array}$ \\
\hline per & 3.12 & bld & Political stake only. & $\begin{array}{l}\text { There was one case involving the mayor of Charleston, } \\
\text { SC. He supported more stringent seismic codes } \\
\text { because he would be held accountable if he did not } \\
\text { and an earthquake occurred. The issue of liability } \\
\text { makes them stakeholders. }\end{array}$ \\
\hline per & 3.13 & reg & $\begin{array}{l}\text { Building regulators are accountable } \\
\text { to political jurisdiction. }\end{array}$ & $\begin{array}{l}\text { The key is accountability. If a restriction is loosened } \\
\text { and something happens, then the regulators will be } \\
\text { asked why the weaker standard was approved. }\end{array}$ \\
\hline per & 3.14 & cst & $\begin{array}{l}\text { Code officials are responsible to } \\
\text { occupants. }\end{array}$ & $\begin{array}{l}\text { The interest of the regulators becomes parallel with that } \\
\text { of the homeowners. }\end{array}$ \\
\hline per & 3.15 & mcd & $\begin{array}{l}\text { Study says regulator not a } \\
\text { stakeholder: } \\
\text { Code enforcer responsible to } \\
\text { occupant, not owner } \\
\text { Interested in LCC, but may not have } \\
\text { any leverage in the process }\end{array}$ & $\begin{array}{l}\text { We have to define "stakeholder." If it is defined as a } \\
\text { group having a financial stake in a project, then } \\
\text { regulators are not stakeholders. If it is defined as a } \\
\text { group having a stake in the outcome of a project, then } \\
\text { regulators are. In that case, must define their stake, } \\
\text { such as in LCC vs. first cost (as far as their view of } \\
\text { LCC). But some of the mechanisms to affect LCC are } \\
\text { not available to regulators. } \\
\text { A code enforcer is a stakeholder by the formal } \\
\text { definition of the term, but it cannot be inferred or } \\
\text { assumed that a code enforcer feels any obligation to } \\
\text { find the most acceptable way for a building project to } \\
\text { go forward. A code enforcer can live with there being } \\
\text { no building; it is not clear that any of the other } \\
\text { stakeholders can. }\end{array}$ \\
\hline per & 3.16 & reg & $\begin{array}{l}\text { Complicated role, but state owns a } \\
\text { lot of property (and has a stake at } \\
\text { least to that extent) }\end{array}$ & $\begin{array}{l}\text { The state of Maryland may be different in that. In } \\
\text { addition to its role as code regulator, the state of } \\
\text { Maryland owns some Maryland homes. The dual role } \\
\text { as a regulator and owner allows it to achieve some } \\
\text { objectives. }\end{array}$ \\
\hline met & 3.17 & reg & $\begin{array}{l}\text { State/regulator is interested in both } \\
1^{\text {st }} \text { costs and LCC }\end{array}$ & $\begin{array}{l}\text { The state/regulator is interested in both first costs and } \\
\text { LCC. }\end{array}$ \\
\hline per & 3.171 & own & (see notes) & $\begin{array}{l}\text { One stake is that infrastructure costs are huge, } \\
\text { monolithic. It affects the local public interest so the } \\
\text { entire community has a stake when new housing is } \\
\text { built. }\end{array}$ \\
\hline per & 3.18 & bld & $\begin{array}{l}\text { Long term interests align regulators } \\
\text { and existing building owners }\end{array}$ & $\begin{array}{l}\text { One issue is that most voters live in existing homes, not } \\
\text { new homes. Therefore, this group drives policy and } \\
\text { regulations. }\end{array}$ \\
\hline per & 3.19 & rch & $\begin{array}{l}\text { Never seen an economics } \\
\text { discussion at a codes hearing } \\
\text { (contrary example cited: stair } \\
\text { geometry cost implications stopped } \\
\text { adoption) }\end{array}$ & $\begin{array}{l}\text { In my experience, economics are not discussed at } \\
\text { proposed code changes, with one exception. In that } \\
\text { case, about eight or nine years ago, there was a } \\
\text { proposal to change stair geometry. This proposed } \\
\text { change would have changed the footprints of most } \\
\text { townhomes in the United States. Economic analysis } \\
\text { was commissioned, and the proposal was eventually } \\
\text { dropped. But the code world in general does not }\end{array}$ \\
\hline
\end{tabular}




\begin{tabular}{|c|c|c|c|c|}
\hline 产 & 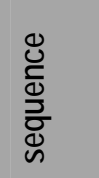 & 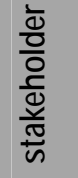 & 'flip chart' record & NIST notes \\
\hline & & & & $\begin{array}{l}\text { conduct economic assessment of proposed changes } \\
\text { because the assessments are too expensive. }\end{array}$ \\
\hline met & 3.20 & $\mathrm{mcd}$ & $\begin{array}{l}\text { Disagree; energy issue was driven } \\
\text { by economics and 'easy' LCC } \\
\text { analysis. LCC is more difficult as } \\
\text { you move to life-safety and other } \\
\text { issues }\end{array}$ & $\begin{array}{l}\text { I disagree. One counterexample is in energy codes } \\
\text { during the 1970s, which looked at payback periods and } \\
\text { assumptions about utility price escalation rates. With } \\
\text { life safety, however, an article in this Sunday's } \\
\text { Washington Post described that the value of life } \\
\text { depended on the age of the individual. Aside from this, } \\
\text { economics are not in pure safety issues, that is true. }\end{array}$ \\
\hline per & 3.21 & fin & $\begin{array}{l}\text { Codes can only address a minimum } \\
\text { level of safety }\end{array}$ & $\begin{array}{l}\text { But what is the purpose of the codes? Every ratchet up } \\
\text { of the code ratchets up the cost. }\end{array}$ \\
\hline met & 3.22 & bld & $\begin{array}{l}\text { It is difficult to argue safety versus } \\
\text { economics in a public forum }\end{array}$ & $\begin{array}{l}\text { Qualitative benefits and costs come together to } \\
\text { determine the value; insurance companies are not } \\
\text { interested in adding sprinklers to all buildings because } \\
\text { of financial costs (projected costs of water damage } \\
\text { from the sprinklers is too high) }\end{array}$ \\
\hline met & 3.23 & cst & $\begin{array}{l}\mathrm{GFCl} \text { introduction to codes was } \\
\text { argued from both standpoints, but } \\
\text { not in public discussions }\end{array}$ & $\begin{array}{l}\text { There are two other examples. LCC analysis was done } \\
\text { on a NIST project on GFCl and on safety glazing, and } \\
\text { they are now in all codes. }\end{array}$ \\
\hline met & 3.24 & $\mathrm{mcd}$ & $\begin{array}{l}\text { SF home sprinklers cost/benefit is a } \\
\text { contemporary example: insurance } \\
\text { companies have not } \\
\text { recognized/acted on home } \\
\text { sprinklers, except in gross way that } \\
\text { smoke alarms are } \\
\text { recognized/discounted. }\end{array}$ & $\begin{array}{l}\text { Another example is in fire safety, with sprinklers and } \\
\text { sprays. There were LCC comparisons of these } \\
\text { sprinkler requirements. One issue is that insurance } \\
\text { companies do not offer a discount in premiums for } \\
\text { home sprinklers. They only offer token discounts, such } \\
\text { as for deadbolts and smoke detectors. One exception } \\
\text { of an incentive for sprinklers is for community-wide } \\
\text { sprinklers that are concentrated in a locality. This } \\
\text { incentive is due to the fact that this group of houses } \\
\text { having sprinklers makes building a fire station to } \\
\text { service that locality unnecessary. The same number of } \\
\text { houses with sprinklers scattered over a wider } \\
\text { geographic area would not have the same effect. So } \\
\text { LCC and first costs are thought about, but not explicitly. }\end{array}$ \\
\hline met & 3.241 & rch & (see notes) & $\begin{array}{l}\text { If LCC is not treated explicitly, then it is not at all, } \\
\text { because it is a black box. }\end{array}$ \\
\hline met & 3.25 & fin & $\begin{array}{l}\text { Difficulty costing rare events? No, it } \\
\text { is a known actuarial experience } \\
\text { base. }\end{array}$ & (see record) \\
\hline met & 3.251 & bld & (see notes) & $\begin{array}{l}\text { LCC analysis is done qualitatively rather than } \\
\text { quantitatively. Small expense items, such as smoke } \\
\text { detectors, are more easily added to codes than big } \\
\text { expense items. }\end{array}$ \\
\hline met & 3.252 & mcd & (see notes) & $\begin{array}{l}\text { That is only two of the four boxes. What about the big } \\
\text { cost/big benefit and low cost/low benefit items? } \\
\text { Accepting low cost/high benefit and rejecting high } \\
\text { cost/low benefit changes are no-brainers. }\end{array}$ \\
\hline met & 3.253 & rch & (see notes) & $\begin{array}{l}\text { This is the purpose of the workshop, to propose a way } \\
\text { of measuring affordability. }\end{array}$ \\
\hline met & 3.254 & fin & (see notes) & $\begin{array}{l}\text { One reason this is difficult is because we do not know } \\
\text { how to price a rare event. }\end{array}$ \\
\hline
\end{tabular}




\begin{tabular}{|c|c|c|c|c|}
\hline 产 & 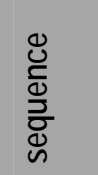 & 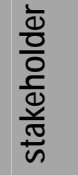 & 'flip chart' record & NIST notes \\
\hline met & 3.255 & cst & (see notes) & Insurers know how to do this. \\
\hline met & 3.256 & mcd & (see notes) & $\begin{array}{l}\text { The NFPA has data on fatalities and injuries due to fire } \\
\text { with and without sprinklers. }\end{array}$ \\
\hline met & 3.257 & fin & (see notes) & One example is lead paint. It was costly to change. \\
\hline per & 3.258 & bld & (see notes) & $\begin{array}{l}\text { Insurers do not take a position on home sprinklers } \\
\text { because the losses due to fire damage and those due } \\
\text { to water damage are the same. The presence of } \\
\text { sprinklers makes no difference to their underwriting } \\
\text { business. }\end{array}$ \\
\hline per & 3.26 & $\mathrm{mcd}$ & $\begin{array}{l}\text { Insurers look at data, financial } \\
\text { consequences; life safety may } \\
\text { change picture } \\
\text { Regulators come as close as any } \\
\text { stakeholder that looks at all } \\
\text { considerations }\end{array}$ & $\begin{array}{l}\text { The financial decision may be indifferent, but life safety } \\
\text { is excluded from that. Analysis with life safety is an } \\
\text { entirely different issue. The regulator is a stakeholder } \\
\text { that is closest to looking at all these costs and issues in } \\
\text { LCC. Therefore, it is not a bad place to start. }\end{array}$ \\
\hline met & 3.27 & cst & $\begin{array}{l}\text { Smoke detector example: } \\
\text { production reduced costs from } \$ 100 \\
\text { to } \$ 5 \text { and changed the economics }\end{array}$ & $\begin{array}{l}\text { Several years ago, when smoke detectors cost over } \\
\$ 100 \text { each, the decision was more difficult. Now that } \\
\text { they cost a few dollars, nobody objects to their } \\
\text { inclusion in the code. }\end{array}$ \\
\hline bar & 3.271 & bld & (see notes) & $\begin{array}{l}\text { The price affected how quickly it was adopted and } \\
\text { penetrated the market. }\end{array}$ \\
\hline bar & 3.28 & bld & $\begin{array}{l}\text { Regulators are in place to protect } \\
\text { public interest, but ("lag v stove bolt } \\
\text { prescription") we've created a } \\
\text { stakeholder we did not want. }\end{array}$ & $\begin{array}{l}\text { Regulators are there to protect the public and not to } \\
\text { have their own interest. But this is not always how it } \\
\text { plays out. For example, I had to replace } 1 / 2 \text {-inch } \\
(12.7 \mathrm{~mm}) \text { lag bolts installed with nut and washer with } \\
3 / 8 \text {-inch }(9.525 \mathrm{~mm}) \text { bolts on a cathedral ceiling because } \\
\text { the code called for the } 3 / 8 \text {-inch }(9.525 \mathrm{~mm}) \text { bolts, and } \\
\text { code official demanded this. Replacing these bolts } \\
\text { took about } 10 \text { labor hours and } \$ 150 \text { in materials. } \\
\text { Would there have been a difference in performance if } \\
\text { the } 1 / 2 \text {-inch }(12.7 \mathrm{~mm}) \text { lag bolts with nut and washer had } \\
\text { stayed? }\end{array}$ \\
\hline per & 3.29 & cst & $\begin{array}{l}\text { Code official is both stakeholder and } \\
\text { part of production team }\end{array}$ & $\begin{array}{l}\text { The lag bolt would probably have met the minimum } \\
\text { performance standard, but the code official may have } \\
\text { lacked the technical background to know this. This is a } \\
\text { recognized problem. The problem is that code officials } \\
\text { are not involved in the design stage and are only } \\
\text { brought in at the end of the process. When they have } \\
\text { objections at this point, they are seen as impediments. }\end{array}$ \\
\hline per & 3.30 & reg & $\begin{array}{l}\text { Education and professionalism of } \\
\text { inspectors is important }\end{array}$ & $\begin{array}{l}\text { This is a timely issue because it will get worse before it } \\
\text { gets better. Inspectors need to be better trained and } \\
\text { higher quality. Labor also needs better training. }\end{array}$ \\
\hline bar & 3.31 & $\mathrm{mcd}$ & $\begin{array}{l}\text { "never enough time to do it right; } \\
\text { always enough time to do it over" }\end{array}$ & $\begin{array}{l}\text { The thinking is that "There is no time to do it right, but } \\
\text { always time to do it over." Code officials will make } \\
\text { mistakes, but we are better off with them to provide the } \\
\text { check than we would be without them. } \\
\text { The manner in which public safety is ensured by having } \\
\text { some sort of check in housing standards (through } \\
\text { codes) is important, better than having nothing. }\end{array}$ \\
\hline bar & 3.311 & cst & (see notes) & Officials in New York State have stated that adoption of \\
\hline
\end{tabular}




\begin{tabular}{|c|c|c|c|c|}
\hline 产 & 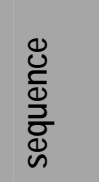 & 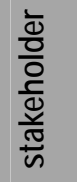 & 'flip chart' record & NIST notes \\
\hline & & & & $\begin{array}{l}\text { building codes was based on costs and benefits. } \\
\text { Regulator stakeholders are multidimensional and } \\
\text { heterogeneous. Political jurisdictions affect this. }\end{array}$ \\
\hline bar & 3.32 & rch & $\begin{array}{l}\text { Is there a "durability mortgage"? } \\
\text { Has been announced, but what is it? } \\
\text { What is the potential for impact on } \\
\text { future value of housing condition? }\end{array}$ & $\begin{array}{l}\text { The question is LCC vs. durability. I have heard that } \\
\text { Fannie is developing a durability mortgage. What is it? } \\
\text { Is it similar to the energy-efficient mortgage? What } \\
\text { does it cover? }\end{array}$ \\
\hline bar & 3.33 & fin & $\begin{array}{l}\text { May be home keeper mortgage- } \\
\text { borrower is essentially buying } \\
\text { insurance (on performance.?) }\end{array}$ & $\begin{array}{l}\text { This could be what is called the "Homekeeper } \\
\text { Mortgage." It sets a bar where the bar is an insurance } \\
\text { policy. The homeowner pays a fee into escrow every } \\
\text { month. If an element of the home goes bad, then the } \\
\text { insurance will pay to repair it. It is insurance for } \\
\text { durability. The fee will determine the effect on the } \\
\text { mortgage. }\end{array}$ \\
\hline met & 3.34 & fin & $\begin{array}{l}\text { In MF housing, debt ratio is } \\
\text { determinant-must consider the } \\
\text { viability of the structure (due } \\
\text { diligence) } \\
\text { Home inspections could serve a } \\
\text { similar purpose for SF }\end{array}$ & $\begin{array}{l}\text { This is another example of innovation in mortgage } \\
\text { lending. Underwriting decisions for SF homes are } \\
\text { based on creditworthiness of the borrower, not the } \\
\text { value of the asset. If the consumer values it, they will } \\
\text { pay for it. With multi-family housing, the situation is } \\
\text { different. In this case, lenders look at the value of the } \\
\text { asset, not creditworthiness of the borrower, when } \\
\text { making underwriting decision. They look at the viability } \\
\text { of the structure as the ratio of liability to the value of the } \\
\text { asset. }\end{array}$ \\
\hline met & 3.341 & own & (see notes) & $\begin{array}{l}\text { With single-family homes, the assumption is that equity } \\
\text { being built up will pay for maintenance. }\end{array}$ \\
\hline met & 3.342 & rch & (see notes) & This is why there are no more FHA inspections. \\
\hline met & 3.35 & mcd & $\begin{array}{l}\text { Home inspections are an innovation } \\
\text { in themselves }\end{array}$ & $\begin{array}{l}\text { Another innovation is the use of home inspectors. } \\
\text { They are an access point for the borrower. }\end{array}$ \\
\hline met & 3.351 & bld & (see notes) & $\begin{array}{l}\text { Home inspectors are used only in some areas. In } \\
\text { others, people will not pay for them. For example, with } \\
\text { my mother's home in southern Virginia, the real estate } \\
\text { agent was unwilling to have a home inspector. In the } \\
\text { DC area, on the other hand, where incomes are higher } \\
\text { and people are willing to pay for it, people expect it. }\end{array}$ \\
\hline met & 3.352 & mcd & (see notes) & $\begin{array}{l}\text { As with innovations, the practice has to disseminate } \\
\text { first. It takes hold where it is most affordable rather } \\
\text { than where it is most needed. }\end{array}$ \\
\hline seg & 3.36 & rch & $\begin{array}{l}\text { Reflects more intense use of } \\
\text { existing stock; SF transaction very } \\
\text { different from MF }\end{array}$ & $\begin{array}{l}\text { Another problem is that few states certify home } \\
\text { inspectors. }\end{array}$ \\
\hline seg & 3.361 & cst & (see notes) & $\begin{array}{l}\text { This is another difference between single-family and } \\
\text { multi-family housing. With multi-family, inspection is } \\
\text { considered due diligence. }\end{array}$ \\
\hline met & 3.362 & rch & (see notes) & $\begin{array}{l}\text { What if defaults on mortgages for single-family homes } \\
\text { occur? Does the value of the asset still not matter? }\end{array}$ \\
\hline met & 3.363 & fin & (see notes) & $\begin{array}{l}\text { Foreclosure is rare: has nothing to do with the actual } \\
\text { house, but the credit of the individual. Freddie Mac has } \\
\text { a default rate of less than } 1 \% \text {, so foreclosure is not a } \\
\text { factor for most mortgages. The issue is whether the }\end{array}$ \\
\hline
\end{tabular}




\begin{tabular}{|c|c|c|c|c|}
\hline 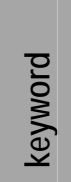 & 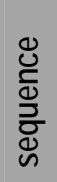 & 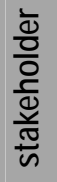 & 'flip chart' record & NIST notes \\
\hline & & & & $\begin{array}{l}\text { market will move the house. There is no bubble in the } \\
\text { housing market. }\end{array}$ \\
\hline
\end{tabular}

Discussion session \#4: How does each stakeholder view and compute future benefits that are uncertain or contingent on very low probability events, such as protection from earthquakes or hurricanes that may never happen, at both scales? What happens when you add uncertainty to the costs and benefits discussed in session \#3?

\begin{tabular}{|c|c|c|c|c|}
\hline 잏 & 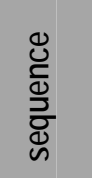 & 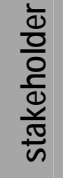 & 'flip chart' record & NIST notes \\
\hline met & 4.01 & rch & $\begin{array}{l}\text { Texas Tech blind studies of } \\
\text { recapture of costs for storm } \\
\text { mitigation-market signal (visible } \\
\text { innovation) aided market } \\
\text { acceptance } \\
\text { Risk perception (Wharton)-folks } \\
\text { cannot differentiate risks } \\
\text { Looking at incentives-insurance } \\
\text { premium reduction; reduced } \\
\text { community costs recognized thru } \\
\text { transfer tax credit if dwelling is } \\
\text { improved }\end{array}$ & $\begin{array}{l}\text { - Texas Tex Wind Center conducted an empirical study } \\
\text { of storm blinds based on a cross section of } 6000 \text { units } \\
\text { to look at how additional costs are recaptured when the } \\
\text { house is sold. Market signal because potential buyers } \\
\text { could see the possible results from upgrading blinds. } \\
\text { Potential buyers could see the storm blinds and the } \\
\text { premium associated with it. } \\
\text { - How do people view risks? According to a risk } \\
\text { perception study at Wharton: most people can't } \\
\text { differentiate between } 1 / 1000 \text { and } 1 / 1000000 \\
\text { probability - How can we help people understand the } \\
\text { dangers? } \\
\text { - If homeowners take steps to protect property, tax } \\
\text { rebate could be a good incentive. There are economic } \\
\text { incentives for both parties. There is an insurance } \\
\text { premium associated with a mortgage. Economic } \\
\text { incentives can be used to lower reductions in insurance } \\
\text { premiums. If you improve your dwelling, the less the } \\
\text { community has to do. Can deduct } 1 / 2 \% \text { when you } \\
\text { transfer the property. }\end{array}$ \\
\hline att & 4.02 & bld & $\begin{array}{l}\text { Interested in minimum health and } \\
\text { safety standards } \\
\text { Group 1-low occupancy, low } \\
\text { value; Group 2,3---residences, } \\
\text { schools; Group 4-nuclear, } \\
\text { chemical, 1st responders; event- } \\
\text { frequent to very rare; magnitude- } \\
\text { small to large }\end{array}$ & $\begin{array}{l}\text { - The state of South Carolina does not believe their } \\
\text { earthquake provision is where it should be. Large } \\
\text { events, such as floods, for example, caused flood } \\
\text { claims to be changed. Insurance companies go to the } \\
\text { re-insurer. Premiums are based on worst-case } \\
\text { scenarios. It's difficult to figure risk-based premiums. } \\
\text { Some people will pay more and some will pay less. The } \\
\text { homeowner who can least afford it, pays the most. } \\
\text { - Balance magnitude of improbable event and } \\
\text { magnitude of possible damage. (see table handout) i.e. } \\
\text { earthquake is less risk tolerant than high winds } \\
\text { - If a rare event occurs, it makes people perceive that } \\
\text { the event is more likely to occur again. }\end{array}$ \\
\hline met & 4.021 & cst & (see notes) & $\begin{array}{l}\text { What is often ignored is that risk has two dimensions, } \\
\text { both the probability of the event and the consequences. } \\
\text { Must balance with magnitude of an improbable event }\end{array}$ \\
\hline
\end{tabular}




\begin{tabular}{|c|c|c|c|c|}
\hline 高 & 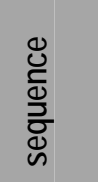 & 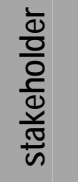 & 'flip chart' record & NIST notes \\
\hline & & & & with the magnitude of the possible damage. \\
\hline met & 4.022 & fin & (see notes) & $\begin{array}{l}\text { The occurrence of an event affects perceptions about } \\
\text { its probability. If a rare event occurs, it makes people } \\
\text { perceive that the event is more likely to occur again. }\end{array}$ \\
\hline met & 4.03 & cst & $\begin{array}{l}\text { Insurance Services Organization } \\
\text { (ISO) program to rate communities } \\
\text { and code enforcement }\end{array}$ & $\begin{array}{l}\text { The Insurance Services Office (ISO) conducts the } \\
\text { BCEGS (Building Code Effectiveness Grading } \\
\text { Schedule) program about the quality of codes and code } \\
\text { enforcement. The insurance industry uses this data. }\end{array}$ \\
\hline bar & 4.04 & fin & $\begin{array}{l}\text { Risk-based insurance may have } \\
\text { contrary effect of increasing costs to } \\
\text { those that can least afford }\end{array}$ & $\begin{array}{l}\text { Insurers pool risk. Premiums are based on worst-case } \\
\text { scenarios. Insurers' concern is, what is their exposure? } \\
\text { Risk premiums are a means of getting rid of the cross } \\
\text { subsidization of the high risk by the low risk. If risk } \\
\text { premiums were used, we would probably see the } \\
\text { lowest income owners paying the highest premiums. } \\
\text { Also, underwriting would be much more difficult. It } \\
\text { would have to be done on a case-by-case basis. }\end{array}$ \\
\hline per & 4.05 & cst & $\begin{array}{l}\text { How do you communicate } \\
\text { magnitude, probability, and } \\
\text { performance to each stakeholder } \\
\text { group }\end{array}$ & $\begin{array}{l}\text { Magnitude of a loss is based on the magnitude of the } \\
\text { initial event. Risk of building falling down comes from } \\
\text { how well the initial design was equipped to handle } \\
\text { wind, for example. Certain embedded assumptions as } \\
\text { to how to make decisions. People are trying to } \\
\text { understand quantitative data on a qualitative level. } \\
\text { People's normal lifetime experiences do not allow them } \\
\text { to factor for extreme events. Consideration of life loss } \\
\text { vs. economic loss - larger corporations are concerned } \\
\text { with investment and maintaining the ability to continue } \\
\text { running. }\end{array}$ \\
\hline met & 4.06 & mcd & $\begin{array}{l}\text { Fire does not fit matrix well-most } \\
\text { start small and not from externality } \\
\text { but from human action } \\
\text { Most stakeholders ignore low } \\
\text { magnitude events-handling } \\
\text { quantitative info qualitatively } \\
\text { How are hazards addressed? Some } \\
\text { keep building in flood plains despite } \\
\text { regular reminders } \\
\text { Matrix works well for natural } \\
\text { hazards (eq, storms, etc.) but not for } \\
\text { high frequency events ("impossible" } \\
\text { v. "intolerable") }\end{array}$ & $\begin{array}{l}\text { Fire does not fit well into the matrix in the handout, } \\
\text { which is good for seismic risks. The matrix assumes } \\
\text { that the way to affect performance is by moderating } \\
\text { consequences, with no control over the occurrence of } \\
\text { the event. In the case of fire, however, the event is } \\
\text { usually caused by humans. Action is not only in } \\
\text { damage control, but also in prevention. Sometimes, it } \\
\text { is possible that there is no flaw in a design, but there is } \\
\text { a flaw in the process of executing or building the } \\
\text { design. Basically, there are two categories of hazards: } \\
\text { impossible, and intolerable. The day after an event, it } \\
\text { switches categories. There are also assumptions about } \\
\text { what is allowable and who would prevent it. For } \\
\text { example, there are people who do not think about fire } \\
\text { hazards. And people built in flood plains until flood } \\
\text { insurance was mandated. When life events do not } \\
\text { provide a good basis for subjective probability } \\
\text { assessment, people do not know how to perceive risk. } \\
\text { Also, if events occur that run counter to their } \\
\text { expectations, the response is distrust of the source of } \\
\text { the information about risk rather than acknowledgement } \\
\text { that the information was misunderstood. }\end{array}$ \\
\hline met & 4.07 & own & Need to change terms of reference & The perception of risk is that a 100 year flood cannot \\
\hline
\end{tabular}




\begin{tabular}{|c|c|c|c|c|}
\hline 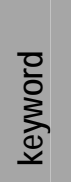 & 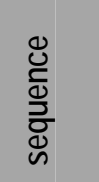 & 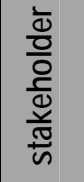 & 'flip chart' record & NIST notes \\
\hline & & & $\begin{array}{l}\text { for risk-100 year flood as likely } \\
\text { again next year as this year }\end{array}$ & $\begin{array}{l}\text { happen two years in a row. There is no recognition that } \\
\text { the probabilities are independent from one year to the } \\
\text { next. When speaking of the } 100 \text { year flood, there is the } \\
\text { same probability at } 2003 \text { as } 2004 \text {. }\end{array}$ \\
\hline met & 4.071 & mcd & (see notes) & $\begin{array}{l}\text { If there were two floods in } 2 \text { years, the homeowner } \\
\text { would think they had gotten bad information or have } \\
\text { been lied to. }\end{array}$ \\
\hline att & 4.08 & cst & $\begin{array}{l}\text { - Information used quite different } \\
\text { among groups } \\
\text { - How communicated is very } \\
\text { important (easier to deal with } \\
\text { dollars than life-safety of } \\
\text { specific event) } \\
\text { - Commerce looked closely at } \\
\text { business interruption impacts }\end{array}$ & $\begin{array}{l}\text { There is a role for financiers and insurers. FEMA is } \\
\text { funding the Applied Technology Council (ATC) } 58 \\
\text { project. Some of the results are that the sophistication } \\
\text { with which the point is made matters, such as it is in } \\
\text { terms of life losses or economic losses. People can } \\
\text { deal much better with economic losses in terms of } \\
\text { annualized expected loss associated with a choice or } \\
\text { action, rather than an event. Larger corporations are } \\
\text { concerned with investment and maintaining the ability } \\
\text { to continue running. For example, if it were presented } \\
\text { as probability of minor damage vs. probability of major } \\
\text { damage. People's normal lifetime experiences do not } \\
\text { allow them to factor for extreme events. }\end{array}$ \\
\hline met & 4.09 & mcd & $\begin{array}{l}\text { Return to question of uncertainty- } \\
\text { low maintenance v. high } \\
\text { performance: } \\
\text { - Attracted to low uncertainty } \\
\text { because of focus on } \\
\text { maintenance costs } \\
\text { - Attracted to even high } \\
\text { uncertainty because value of } \\
\text { high performance is important } \\
\text { - Attracted to focus on first cost } \\
\text { only } \\
\text { - Ostriches }\end{array}$ & $\begin{array}{l}\text { There are two types of approaches to mitigation. The } \\
\text { first is high performance, but requires more } \\
\text { maintenance. Whether the maintenance takes place is } \\
\text { a source of uncertainty that affects the likely } \\
\text { performance of the measure. The second is something } \\
\text { that has mediocre performance, but is idiot proof. } \\
\text { There are three groups of individuals: One will choose } \\
\text { mediocre performance because they want to avoid the } \\
\text { uncertainty and maintenance, even at a cost of lower } \\
\text { performance. A second will choose the high } \\
\text { performance option if the uncertainty is controllable by } \\
\text { their own actions. A third may choose the high } \\
\text { performance/high uncertainty option because they care } \\
\text { only about first cost. }\end{array}$ \\
\hline att & 4.10 & bld & $\begin{array}{l}\text { Cannot rely on maintenance for } \\
\text { operation-product will fail }\end{array}$ & $\begin{array}{l}\text { The typical homebuyer prefers zero maintenance. } \\
\text { Most are in the first category. }\end{array}$ \\
\hline att & 4.101 & mcd & (see notes) & $\begin{array}{l}\text { They may be in the first or the third, and may make } \\
\text { choices without thinking about maintenance and the } \\
\text { consequences of those choices. }\end{array}$ \\
\hline seg & 4.102 & bld & (see notes) & $\begin{array}{l}\text { Multi-family housing is different because of liability, } \\
\text { insurance, and the presence of dedicated maintenance } \\
\text { personnel. }\end{array}$ \\
\hline att & 4.11 & mcd & $\begin{array}{l}\text { What about analogy to } \\
\text { automobiles-a defined } \\
\text { maintenance regime? } \\
\text { Why not same attributes for } \\
\text { maintaining homes and system } \\
\text { performance? }\end{array}$ & $\begin{array}{l}\text { In the case of autos, maintenance is key to } \\
\text { performance, and people do it because it is easy to say } \\
\text { yes to it, with remainders and streamlined procedures. }\end{array}$ \\
\hline met & 4.12 & bld & $\begin{array}{l}\$ 1800 \text { per year maintenance } \\
\text { compared to } \$ 235 \mathrm{~K} \text { price-less }\end{array}$ & $\begin{array}{l}\text { Most deterioration of homes occurs over time and is not } \\
\text { instantaneous. But realization of deterioration is }\end{array}$ \\
\hline
\end{tabular}




\begin{tabular}{|c|c|c|c|c|}
\hline 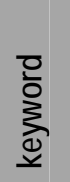 & 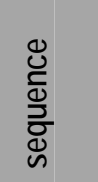 & 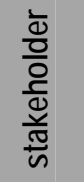 & 'flip chart' record & NIST notes \\
\hline & & & $\begin{array}{l}\text { than } 1 \% \text { per year; national "close } \\
\text { your storm windows day" at } \\
\text { Thanksgiving"? }\end{array}$ & $\begin{array}{l}\text { sudden. For a loan-to-value (LTV) loan of } 80 \% \text {, taxes } \\
\text { and insurance are escrowed. A mortgage company } \\
\text { wants to protect its investments. A Harvard study } \\
\text { found that the average annual expenditure on home } \\
\text { maintenance is } \$ 1800 \text {. The average resale price of a } \\
\text { house is } \$ 237000 \text {. This small amount spent each year } \\
\text { to maintain what for most people is the single largest } \\
\text { repository of their personal assets is less than } 1 \% \text { of } \\
\text { the value of the house. To get the housing stock } \\
\text { maintainable for } 60 \text { years, it may be necessary to } \\
\text { mandate certain requirements. There needs to be } \\
\text { something to encourage and remind homeowners } \\
\text { about maintenance, such as "National Storm Window } \\
\text { Day" on Thanksgiving, and "National Screen Day" on } \\
\text { Memorial Day. }\end{array}$ \\
\hline per & 4.121 & fin & (see notes) & $\begin{array}{l}\text { Maintenance is a major concern relating to the person } \\
\text { who is paying for it at the moment that it occurs. } \\
\text { Consider } 1 \% \text { of purchase price }+ \text { costs of } \\
\text { improvements every year to stabilize the community. }\end{array}$ \\
\hline per & 4.122 & cst & (see notes) & $\begin{array}{l}\text { How does a neighbor become a stakeholder is your } \\
\text { house? When something significant occurs to a single } \\
\text { home, it affects the entire neighborhood (in way of } \\
\text { market value). }\end{array}$ \\
\hline met & 4.13 & mcd & $\begin{array}{l}\text { Frame cost/benefit against another } \\
\text { reference (e.g. value of investment) }\end{array}$ & $\begin{array}{l}\text { It would be helpful to frame the importance of } \\
\text { maintenance not in abstract terms, such as LCC, but in } \\
\text { more tangible terms, such as the number of mortgage } \\
\text { payments. Currently, maintenance is not thought of as } \\
\text { an investment choice, but as an expenditure choice. }\end{array}$ \\
\hline att & 4.14 & bld & $\begin{array}{l}\text { Banks require property tax escrow } \\
\text { (banks protect investment by forcing } \\
\text { compliance), why not similar } \\
\text { approach for maintenance? }\end{array}$ & $\begin{array}{l}\text { Mortgage lenders build in escrow for property tax and } \\
\text { insurance premiums. The same could be done for } \\
\text { maintenance if believe that personal responsibility is } \\
\text { not reliable. }\end{array}$ \\
\hline bar & 4.141 & mcd & (see notes) & $\begin{array}{l}\text { Or draw from the auto analogy, where a warranty } \\
\text { requires adherence to a maintenance schedule. }\end{array}$ \\
\hline per & 4.142 & mcd & (see notes) & $\begin{array}{l}\text { Another example is the mandatory annual safety } \\
\text { inspection for vehicles in Virginia. But autos are not a } \\
\text { good analogy because it is possible to spend more } \\
\text { maintaining a car (as a percentage of value) than on a } \\
\text { house. }\end{array}$ \\
\hline bar & 4.143 & bld & (see notes) & $\begin{array}{l}\text { Educating people is the key. People do not read } \\
\text { instruction manuals. For example, I know someone } \\
\text { who refuses to and therefore cannot operate the VCR. }\end{array}$ \\
\hline met & 4.15 & fin & $\begin{array}{l}\text { It's a time horizon consideration-if } \\
\text { beyond mine, I don't care. }\end{array}$ & $\begin{array}{l}\text { LCC is not a good approach because time horizons are } \\
\text { short. The thinking is that a homeowner can forego } \\
\text { maintenance for } 5 \text { years because the consequences } \\
\text { will not be observable in that time, and can sell with no } \\
\text { penalty. }\end{array}$ \\
\hline att & 4.16 & mcd & $\begin{array}{l}\text { If you ignore maintenance, you are } \\
\text { playing probabilities. }\end{array}$ & People are playing the odds. \\
\hline att & 4.17 & own & High maintenance is not a reliable & A problem is that there are infrequent tests of \\
\hline
\end{tabular}




\begin{tabular}{|c|c|c|c|c|}
\hline 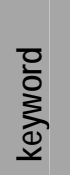 & 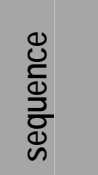 & 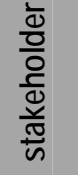 & 'flip chart' record & NIST notes \\
\hline & & & $\begin{array}{l}\text { strategy for low frequency events; } \\
\text { need fail-safe systems }\end{array}$ & $\begin{array}{l}\text { performance with these low probability events. If } \\
\text { there's a low probability, then there's no reason to do } \\
\text { high maintenance. There's a need to look at a fail-safe } \\
\text { system that gives warnings whenever the system is not } \\
\text { in shape. }\end{array}$ \\
\hline met & 4.171 & $\mathrm{mcd}$ & (see notes) & $\begin{array}{l}\text { With maintenance, there is a shift in uncertainty from } \\
\text { one that they cannot control, the realization of an event, } \\
\text { with one that they can control, maintenance. }\end{array}$ \\
\hline met & 4.18 & bld & $\begin{array}{l}\text { Rental property investor seeks } 1 \% \\
\text { property + improvement cash flow in } \\
\text { stable market; delay in maintenance } \\
\text { will penalize the seller; how } \\
\text { much?- - subject of study? }\end{array}$ & $\begin{array}{l}\text { The investment standard is } 1 \% \text { of purchase plus } \\
\text { improvement per month in a stable or ascending } \\
\text { neighborhood. If maintenance is deferred, it penalizes } \\
\text { the seller. The market will adjust at the time of } \\
\text { transaction. }\end{array}$ \\
\hline met & 4.181 & cst & (see notes) & $\begin{array}{l}\text { If the penalty is less than the cost of maintenance, then } \\
\text { the incentive to maintain is not there. }\end{array}$ \\
\hline att & 4.19 & own & $\begin{array}{l}\text { Especially for "high-frequency" } \\
\text { events? }\end{array}$ & $\begin{array}{l}\text { We need to focus on low frequency, low probability } \\
\text { events. Flooding drains, mildew, and fires are more } \\
\text { frequent. Low probability events need to be treated } \\
\text { differently. }\end{array}$ \\
\hline att & 4.20 & cst & $\begin{array}{l}\text { Hurricane protection relies on } \\
\text { maintenance rather than } \\
\text { passive/fail-safe approach. }\end{array}$ & $\begin{array}{l}\text { With hurricanes, there are three mitigation approaches } \\
\text { that are seen as equivalent by the codes. } \\
\text { 1. Build hurricane shutters, and the only } \\
\text { maintenance required is to close them before } \\
\text { the hurricane hits. } \\
\text { 2. Install impact-resistant windows, and the only } \\
\text { maintenance is to close them before the } \\
\text { storm. } \\
\text { 3. Stack plywood, and the maintenance action is } \\
\text { to put it up when the hurricane warning } \\
\text { comes. } \\
\text { Whether high maintenance or low maintenance, there } \\
\text { are options to satisfy the need for protection. The } \\
\text { codes recognize that some prefer low maintenance and } \\
\text { some high. } \\
\text { Standards are met if you are building in a low frequency } \\
\text { event area. }\end{array}$ \\
\hline pro & 4.21 & bld & $\begin{array}{l}\text { Storm shutters useless if not } \\
\text { deployed. }\end{array}$ & $\begin{array}{l}\text { Hurricane shutters are only effective if someone closes } \\
\text { them before the storm. }\end{array}$ \\
\hline seg & 4.22 & reg & $\begin{array}{l}\text { From regulator perspective, recent } \\
\text { looks at contributing factors to fire } \\
\text { found vacancy a strong indicator } \\
\text { and greater frequency of vacancy in } \\
\text { poor areas }\end{array}$ & $\begin{array}{l}\text { From the perspective of regulators, they looked at fire } \\
\text { hazards when setting codes. There are factors aside } \\
\text { from the structure and maintenance that affect this } \\
\text { hazard. For example, the vacant building factor and } \\
\text { low-income factor contribute to both the probability of a } \\
\text { fire and the probability that a fire will result in a fatality. } \\
\text { These factors came into play when it came time to set } \\
\text { the codes. }\end{array}$ \\
\hline seg & 4.23 & mcd & $\begin{array}{l}\text { Untreated wood shingles create } \\
\text { increased risk for surrounding } \\
\text { dwellings; how should it be dealt } \\
\text { with? By insurers, by codes? }\end{array}$ & $\begin{array}{l}\text { There is a special case with fire. If a homeowner uses } \\
\text { untreated wood shingles, then he increases the risk of } \\
\text { a fire to his neighbors. }\end{array}$ \\
\hline
\end{tabular}




\begin{tabular}{|c|c|c|c|c|}
\hline 产 & 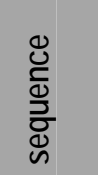 & 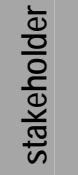 & 'flip chart' record & NIST notes \\
\hline seg & 4.231 & own & (see notes) & $\begin{array}{l}\text { Codes are driven by the rule that "one shalt not burn } \\
\text { your neighbor's home." }\end{array}$ \\
\hline seg & 4.24 & reg & $\begin{array}{l}\text { Commercial use next to vacancy } \\
\text { unable to get insurance; two } \\
\text { buildings away, double the cost. }\end{array}$ & $\begin{array}{l}\text { For buildings next door to vacant buildings, it is } \\
\text { impossible to get fire insurance. }\end{array}$ \\
\hline seg & 4.241 & rch & (see notes) & Is the risk pooled or not? \\
\hline seg & 4.242 & reg & (see notes) & This was for commercial buildings. \\
\hline seg & 4.243 & own & (see notes) & $\begin{array}{l}\text { If one person leaves the house burned down and does } \\
\text { not rebuild, then the entire neighborhood suffers. }\end{array}$ \\
\hline att & 4.25 & fin & $\begin{array}{l}\text { Northridge quake: soft-story } \\
\text { collapse was the problem. }\end{array}$ & $\begin{array}{l}\text { Earthquake insurance was withdrawn for condos in } \\
\text { southern California after the Northridge earthquake. } \\
\text { What was the technical impact? }\end{array}$ \\
\hline att & 4.251 & bld & (see notes) & Now can't build in some places. \\
\hline att & 4.252 & own & (see notes) & Many buildings were retrofitted. \\
\hline att & 4.26 & cst & $\begin{array}{l}\text { Many SF homes with cripple walls } \\
\text { have the same problem. }\end{array}$ & $\begin{array}{l}\text { There were some retrofits, such as the Parapet } \\
\text { program and unreinforced masonry buildings (URMB). } \\
\text { It is difficult to get these programs in place. There } \\
\text { needs to be a public outcry. }\end{array}$ \\
\hline att & 4.261 & fin & (see notes) & Or outcry from the insurers. \\
\hline att & 4.262 & cst & (see notes) & $\begin{array}{l}\text { I have no seismic insurance even though I live in } \\
\text { California because any policy with a reasonable } \\
\text { premium has a deductible of } \$ 40000 \text {. This creates an } \\
\text { incentive for me to build better. }\end{array}$ \\
\hline seg & 4.27 & mcd & $\begin{array}{l}\text { Getting back to vacancy } \\
\text { implications, abandonment of } \\
\text { property leads to leveraged risk for } \\
\text { others }\end{array}$ & $\begin{array}{l}\text { One person's choice to not protect can, if an event } \\
\text { occurs, affect the neighborhood. Vacant houses, for } \\
\text { instance as a result of a fire, cause rot in the } \\
\text { neighborhood. One vacant house soon becomes two } \\
\text { vacant houses, etc. }\end{array}$ \\
\hline per & 4.271 & bld & (see notes) & $\begin{array}{l}\text { But the insurance payout must be used to rebuild the } \\
\text { damaged house, unless the insurance company takes } \\
\text { possession of the damaged property. Typically, an } \\
\text { insurance payout cannot be used to build or buy a } \\
\text { house in an entirely different location. }\end{array}$ \\
\hline per & 4.28 & reg & $\begin{array}{l}\text { There is a historic } \\
\text { model/precedence for government } \\
\text { role in property rights }\end{array}$ & $\begin{array}{l}\text { There is already precedent for government regulation of } \\
\text { home maintenance: historical homes. }\end{array}$ \\
\hline per & 4.281 & own & (see notes) & $\begin{array}{l}\text { Homeowners' associations also play a role in } \\
\text { monitoring maintenance. }\end{array}$ \\
\hline per & 4.282 & fin & (see notes) & How does this relate to affordability? \\
\hline att & 4.29 & mcd & $\begin{array}{l}\text { Need more realistic estimate of } \\
\text { affordability }\end{array}$ & $\begin{array}{l}\text { What is needed is a notion of how affordable houses } \\
\text { are now and connect all the components of affordability } \\
\text { back to the house. }\end{array}$ \\
\hline att & 4.31 & fin & $\begin{array}{l}\text { What is quality level for 'affordable' } \\
\text { housing? Safer means higher cost; } \\
\text { will be the same for all attributes. }\end{array}$ & $\begin{array}{l}\text { Stricter codes reduce affordability. There is a lot of } \\
\text { housing that is affordable that is unlivable. What is the } \\
\text { minimum standard? Here, we are talking about } \\
\text { increasing the minimum standard. Can you achieve the } \\
\text { performance with less expensive materials? What is } \\
\text { the quality level to be achieved? Houses are better } \\
\text { built now and cost less. It is necessary to change costs }\end{array}$ \\
\hline
\end{tabular}




\begin{tabular}{|c|c|c|c|c|}
\hline 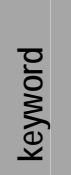 & 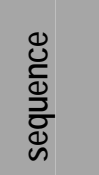 & 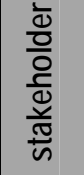 & 'flip chart' record & NIST notes \\
\hline & & & & $\begin{array}{l}\text { to reflect the value of the housing. Increasing } \\
\text { standards would increase costs greatly, which would } \\
\text { lead to a decrease in the availability of affordable } \\
\text { housing. }\end{array}$ \\
\hline met & 4.32 & rch & $\begin{array}{l}\text { Metrics not there to either estimate } \\
\text { or justify increased costs }\end{array}$ & $\begin{array}{l}\text { Need a predictable metric to get the consumer to incur } \\
\text { the cost. }\end{array}$ \\
\hline met & 4.321 & cst & (see notes) & $\begin{array}{l}\text { Or wait for an event to occur to make them want to } \\
\text { incur it. }\end{array}$ \\
\hline met & 4.322 & mcd & (see notes) & $\begin{array}{l}\text { An event would lead to discrete changes in choices, } \\
\text { building codes, and new building technologies. } \\
\text { Experiences are flawed metrics and not rational. }\end{array}$ \\
\hline att & 4.33 & own & $\begin{array}{l}\text { Adherence to enhanced code raised } \\
\text { costs post-Andrew; adherence to } \\
\text { pre-Andrew code reduced losses. } \\
\text { Adherence produces better houses. }\end{array}$ & $\begin{array}{l}\text { In the case of Hurricane Andrew in Florida, the worst hit } \\
\text { part of a newly constructed area was where there had } \\
\text { been an agreement between the builder and inspectors } \\
\text { for self-enforcement of the codes. The self- } \\
\text { enforcement did not work, and the codes were not } \\
\text { enforced. But there was no attention paid to this } \\
\text { reason as the explanation for the damage in this area. } \\
\text { Instead, there was political hue and cry for more } \\
\text { stringent and more idiot-proof codes. But in other } \\
\text { areas, where existing codes were enforced, the homes } \\
\text { withstood the hurricane. }\end{array}$ \\
\hline att & 4.331 & fin & (see notes) & A HUD study also showed this with seismic events. \\
\hline att & 4.332 & mcd & (see notes) & $\begin{array}{l}\text { What if the code changes being demanded were more } \\
\text { idiot proof? For example, in the case of the Rhode } \\
\text { Island nightclub fire, there was lack of adherence to the } \\
\text { code. If sprinklers, a more foolproof device, had been } \\
\text { in place, it would have made a big difference. }\end{array}$ \\
\hline att & 4.333 & fin & (see notes) & $\begin{array}{l}\text { If these changes were to be made, one effect would be } \\
\text { to increase the hurdle rate of the house and make } \\
\text { ownership less affordable. }\end{array}$ \\
\hline att & 4.334 & bld & (see notes) & $\begin{array}{l}\text { Codes are merely an agreed minimal acceptable } \\
\text { standard. }\end{array}$ \\
\hline per & 4.34 & mcd & $\begin{array}{l}\text { Codes are an imperfect but valuable } \\
\text { instrument }\end{array}$ & $\begin{array}{l}\text { Even if imperfectly enforced, codes are better than } \\
\text { nothing. }\end{array}$ \\
\hline per & 4.35 & rch & $\begin{array}{l}\text { Why will insurers push for code } \\
\text { changes, but have no interest in } \\
\text { QA/QC for homebuilders? }\end{array}$ & $\begin{array}{l}\text { Why do codes and changes in existing codes not target } \\
\text { individual housing more directly? } \\
\text { Code changes in Florida occurred in part due to a push } \\
\text { by insurance companies. Why do they not also push } \\
\text { for enforcement and deal with the quality of the house, } \\
\text { which matters much more for affordability and their risk } \\
\text { exposure? }\end{array}$ \\
\hline bar & 4.36 & bld & $\begin{array}{l}\text { Future benefits uncertain or } \\
\text { contingent on future actions (e.g. } \\
\text { zoning) impediments to affordable } \\
\text { product. Correlation to increased } \\
\text { cost and reduced risk. }\end{array}$ & $\begin{array}{l}\text { There is a need to consider affordability impacts when } \\
\text { going from a small lot to a large lot. An example is } \\
\text { consequences of septic failure on ground water quality. } \\
\text { Does the reduction in risk correlate to increase in cost? } \\
\text { What is a reasonable tradeoff for risk? Insurance } \\
\text { companies pushed for changes to double lot sizes. }\end{array}$ \\
\hline bar & 4.361 & cst & (see notes) & Zoning is an issue. \\
\hline bar & 4.362 & bld & (see notes) & There are a number of positive incentives in improving \\
\hline
\end{tabular}




\begin{tabular}{|c|c|c|c|c|}
\hline 产 & 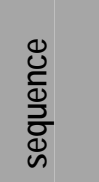 & 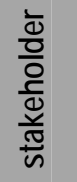 & 'flip chart' record & NIST notes \\
\hline & & & & $\begin{array}{l}\text { and following codes and zoning. The improvement } \\
\text { may trade off with other incentives. }\end{array}$ \\
\hline met & 4.37 & rch & $\begin{array}{l}\text { Analogy to materials research- } \\
\text { better performance at lower cost- } \\
\text { need to get discussion back to } \\
\text { innovation. }\end{array}$ & $\begin{array}{l}\text { Is it possible to increase innovation and decrease cost } \\
\text { at higher quality? Can innovation make the house } \\
\text { more affordable (not the quality of the house)? Better } \\
\text { performance, better cost. }\end{array}$ \\
\hline met & 4.371 & mcd & (see notes) & $\begin{array}{l}\text { Must ask whether cost of quality improvement is } \\
\text { justified by the improvement. }\end{array}$ \\
\hline met & 4.372 & fin & (see notes) & $\begin{array}{l}\text { Can we increase quality and performance while } \\
\text { reducing cost? }\end{array}$ \\
\hline met & 4.373 & rch & (see notes) & $\begin{array}{l}\text { New technology introduction costs must be borne } \\
\text { initially, but the benefits will eventually be realized. } \\
\text { High performance concrete is an example. }\end{array}$ \\
\hline val & 4.38 & rch & $\begin{array}{l}\text { Housing only industry to insist that } \\
\text { innovation requires increased costs. }\end{array}$ & $\begin{array}{l}\text { Housing is the only industry that focuses only on the } \\
\text { increase in initial or early costs associated with } \\
\text { innovation. This is not true in other industries. In the } \\
\text { housing market, initial costs always increase with } \\
\text { increased innovations. Innovation costs more in the } \\
\text { long term. Pulte improved the quality in its framing. }\end{array}$ \\
\hline val & 4.39 & reg & Costs must be considered. & There is little R\&D investment in the housing industry. \\
\hline val & 4.40 & mcd & $\begin{array}{l}\text { No guarantee that innovation either } \\
\text { lowers costs or increases quality }\end{array}$ & $\begin{array}{l}\text { Innovation may reduce cost, but may also reduce } \\
\text { quality. All we know about an innovation is that it is } \\
\text { new (there is uncertainty). }\end{array}$ \\
\hline val & 4.41 & cst & (see notes) & EIFS reduced quality. \\
\hline val & 4.42 & cst & (see notes) & $\begin{array}{l}\text { The problem with EIFS is that it was misapplied. It } \\
\text { came from Europe and was used in the U.S. without } \\
\text { good understanding of how it should be used here. }\end{array}$ \\
\hline
\end{tabular}

\section{Discussion session \#5: How should the uncertainty and risk associated with using new versus traditional technology be addressed, at both scales?}

\begin{tabular}{|c|c|c|c|c|}
\hline 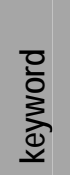 & 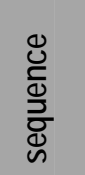 & 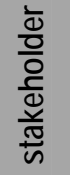 & 'flip chart' record & NIST notes \\
\hline met & 5.01 & fin & $\begin{array}{l}\text { What types of uncertainties? } \\
\text { - Unforeseen costs } \\
\text { - Durability of value } \\
\text { - Consistency of measurement } \\
\quad \text { capability } \\
\text { What types of affordability? }\end{array}$ & $\begin{array}{l}\text { - Interaction between uncertainty and affordability } \\
\text { components. } \\
\text { - Issue: Will the value be maintained in the long run? } \\
\text { Will the house hold its value if the component falls out } \\
\text { of trend or physically falls out? } \\
\text { - Do all innovations have to be held to the same } \\
\text { affordability standards? }\end{array}$ \\
\hline pro & 5.02 & $\mathrm{mfr}$ & $\begin{array}{l}\text { How do we reduce our risk in } \\
\text { introducing new product? } \\
\text { - Evolution is manageable; } \\
\text { revolution involves unforeseen } \\
\text { issues (with greater chance of }\end{array}$ & $\begin{array}{l}\text { - How to mitigate risks and introduce a product } \\
\text { appropriately into the market? Dupont mitigates risk by } \\
\text { the things that they do not envision or focus on. } \\
\text { - E1825 of the ASTM Standard gives a list of what to do } \\
\text { before putting in a new system. }\end{array}$ \\
\hline
\end{tabular}




\begin{tabular}{|c|c|c|c|c|}
\hline 产 & 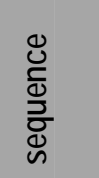 & 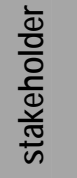 & 'flip chart' record & NIST notes \\
\hline & & & $\begin{array}{l}\text { failure) } \\
\text { - Assessing performance must } \\
\text { be addressed in all areas of } \\
\text { impact. } \\
\text { - ASTM standard E1825 lists } \\
\text { things to look at. } \\
\text { - Should develop installation and } \\
\text { delivery system as product is } \\
\text { developed. }\end{array}$ & $\begin{array}{l}\text { - How to prepare for those risks that you do not initially } \\
\text { envision? - One has to look at all other aspects of } \\
\text { something specific could possibly impact. } \\
\text { - Concurrently one must look at the delivery system } \\
\text { when testing a new product. The delivery system } \\
\text { needs to look at the innovation of the material } \\
\text { - It helps to look beyond first costs to LCC (costs of } \\
\text { owning and operating). They do look for a combination } \\
\text { of installation costs and materials costs. They try to } \\
\text { reduce the cost of owning and operating. }\end{array}$ \\
\hline val & 5.03 & rch & $\begin{array}{l}\text { How do you treat cost of substitute } \\
\text { products? }\end{array}$ & $\begin{array}{l}\text { Is affordability a factor in marketing decisions at your } \\
\text { company? }\end{array}$ \\
\hline met & 5.04 & mfr & $\begin{array}{l}\text { We look at complete LCC, including } \\
\text { replacement cycles. }\end{array}$ & $\begin{array}{l}\text { Not in the first cost, but the cost of materials, } \\
\text { installation costs, callback costs, energy savings, and } \\
\text { durability. }\end{array}$ \\
\hline met & 5.05 & rch & $\begin{array}{l}\text { Are consumers becoming more } \\
\text { sophisticated/sensitive to LCC? } \\
\text { Yes. }\end{array}$ & Do the customers know this? \\
\hline met & 5.051 & mfr & (see notes) & $\begin{array}{l}\text { Builder customers are pretty sophisticated. Training } \\
\text { and education are also part of the package. }\end{array}$ \\
\hline per & 5.06 & rch & $\begin{array}{l}\text { NES 'look beyond code' push } 2 \\
\text { years ago; manufacturers wanted } \\
\text { nothing to do with it. }\end{array}$ & $\begin{array}{l}\text { Other manufacturers may not be interested in testing } \\
\text { and assessment. }\end{array}$ \\
\hline pro & 5.07 & $\mathrm{mcd}$ & $\begin{array}{l}\text { Manufacturers were looking only for } \\
\text { market-pull demand for any aspect } \\
\text { of product characteristics }\end{array}$ & $\begin{array}{l}\text { There is no point in showing characteristics of products } \\
\text { that no one cares about. }\end{array}$ \\
\hline pro & 5.08 & rch & $\begin{array}{l}\text { Lots of visible innovation is by small } \\
\text { companies with low capitalization } \\
\text { looking to push innovation into } \\
\text { market with little testing or success. }\end{array}$ & $\begin{array}{l}\text { The concern is this, truly innovative producers are very } \\
\text { small-scale producers, who may not have the } \\
\text { resources to test and are the worst when it comes to } \\
\text { assessing products before market introduction. } \\
\text { Massive industry failures are documented on PATH's } \\
\text { website. HUD did a study of EIFS and engineered I- } \\
\text { joists. With EIFS, which was a failure, it was produced } \\
\text { by small, fly-by-night producers who did not do } \\
\text { homework on the proper application of the technology. } \\
\text { With engineered I-joists, which was a success, the } \\
\text { producers were big companies who had performed } \\
\text { long, comprehensive analysis of the product and } \\
\text { process. There is a riskiness to new products that is } \\
\text { inherent that is not addressed by producers. In the ICC } \\
\text { Evaluation Service guide to innovations, the idea is } \\
\text { "getting the technology accepted." }\end{array}$ \\
\hline bar & 5.09 & own & $\begin{array}{l}\text { Code can be a barrier; may be used } \\
\text { by existing manufacturers to block } \\
\text { products. }\end{array}$ & $\begin{array}{l}\text { Codes can be used by incumbent producers to block } \\
\text { new products. }\end{array}$ \\
\hline pro & 5.10 & $\mathrm{mfr}$ & $\begin{array}{l}\text { Prescriptive standards represent } \\
\text { "the way things have been done"- } \\
\text { new product must test against } \\
\text { existing product and evaluate } \\
\text { existing product for comparison. }\end{array}$ & $\begin{array}{l}\text { Some code elements that are prescriptive are based on } \\
\text { tradition and have not been tested. To introduce a new } \\
\text { product that satisfies the same purpose, it is necessary } \\
\text { to not only test the new product, but to test the existing } \\
\text { method as well, for a comparison. This is very costly. }\end{array}$ \\
\hline
\end{tabular}




\begin{tabular}{|c|c|c|c|c|}
\hline 产 & 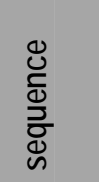 & 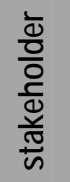 & 'flip chart' record & NIST notes \\
\hline pro & 5.101 & rch & (see notes) & $\begin{array}{l}\text { How much does this manufacturer use the ICC } \\
\text { Evaluation Service? }\end{array}$ \\
\hline pro & 5.102 & $\mathrm{mfr}$ & (see notes) & We use it. \\
\hline pro & 5.11 & mcd & $\begin{array}{l}\text { Armstrong testing, "no surprises", at } \\
\text { one end; other extreme, "kitchen } \\
\text { only sprinkler" emphasizing/ } \\
\text { distorting kitchen risk. } \\
\text { How should evaluation be done- } \\
\text { staged, as in drug development } \\
\text { analogy? } \\
\text { Testing, more testing, then wait for } \\
\text { time before it gets out. } \\
\text { Find a way to keep good products } \\
\text { alive long enough to check } \\
\text { performance. } \\
\text { Beta testing/trial market: } \\
\text { 1. Assessment by manufacturer } \\
\text { 2. Controlled assessment by a } \\
\text { limited population } \\
\text { 3. General distribution }\end{array}$ & $\begin{array}{l}\text { Some of this discussion belongs in discussion session } \\
7 \text { later. At the fire testing college at Armstrong, the } \\
\text { mantra is "no surprises." How can the uncertainty about } \\
\text { new products be reduced to better predict performance, } \\
\text { so the good innovations will get through, but the bad } \\
\text { ones will not? How do you get a system where the } \\
\text { good innovations get out while the bad are stopped } \\
\text { quickly? There are three stages of assessments: } \\
\text { 1. Manufacturer's assessment } \\
\text { 2. Controlled assessment using a limited population } \\
\text { (such as beta testing with electronics) } \\
\text { 3. Widespread, general distribution } \\
\text { This staged process is used in the pharmaceutical } \\
\text { approval process. It requires a great deal of time and } \\
\text { money, but with limited exposure to people. Some } \\
\text { disapprove of this process. }\end{array}$ \\
\hline pro & 5.111 & rch & (see notes) & $\begin{array}{l}\text { The drug industry is a poor example. The FDA is a } \\
\text { notorious bottleneck, and the process drives up the } \\
\text { cost of drugs. }\end{array}$ \\
\hline pro & 5.112 & mcd & (see notes) & $\begin{array}{l}\text { I wanted to refer to drugs as an example of a staged } \\
\text { approval process. }\end{array}$ \\
\hline del & 5.12 & rch & $\begin{array}{l}\text { Problem is materials must be sent to } \\
\text { "Fred"//rd party to put in place. } \\
\text { Systems integration is needed. } \\
\text { Capital intensive-engineered } \\
\text { product is the answer. }\end{array}$ & $\begin{array}{l}\text { We need testing under realistic, standard conditions. It } \\
\text { is extremely capital intensive to test products until } \\
\text { people start to buy them. One problem is that there are } \\
\text { disparate actors in the assembly process. It is not just } \\
\text { the design of the product. It will fail if there is no } \\
\text { systems integration. Must also consider Fred the } \\
\text { manufacturer, assembler, contractor. Products with } \\
\text { integration challenges are more likely to fail. } \\
\text { Engineered products will be superior to assembled } \\
\text { products. It will happen in the housing industry in the } \\
\text { next } 5 \text { years to } 10 \text { years. Big companies doing this will } \\
\text { succeed. }\end{array}$ \\
\hline pro & 5.13 & mcd & $\begin{array}{l}\text { Interactions (among stakeholders) } \\
\text { are a key aspect in changing } \\
\text { product development }\end{array}$ & $\begin{array}{l}\text { To carry the drug analogy to this, the issue is drug } \\
\text { interactions. Is the product sensitive to assembly } \\
\text { issues? }\end{array}$ \\
\hline pro & 5.131 & mfr & (see notes) & $\begin{array}{l}\text { "Controlled assessment" is already done, through test } \\
\text { marketing (or beta testing, for some industries). These } \\
\text { assessments are done now, but not to code, because } \\
\text { the code is just a minimum standard to market trial. My } \\
\text { company sets up early trials so that the odds of a } \\
\text { successful market trial are close to } 50 / 50 \text {. A better } \\
\text { analogy may be the auto industry as an assembler of a } \\
\text { system. Quality is outsourced to first-tier suppliers. }\end{array}$ \\
\hline pro & 5.132 & rch & (see notes) & $\begin{array}{l}\text { With autos, though, the components are highly } \\
\text { engineered. }\end{array}$ \\
\hline
\end{tabular}




\begin{tabular}{|c|c|c|c|c|}
\hline 产 & 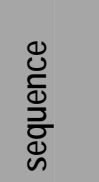 & 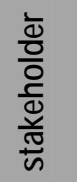 & 'flip chart' record & NIST notes \\
\hline pro & 5.133 & bld & (see notes) & $\begin{array}{l}\text { Testing is costly. A builder with just a few lots cannot } \\
\text { spread the costs among many units. }\end{array}$ \\
\hline del & 5.14 & bld & $\begin{array}{l}\text { Group is making a great argument } \\
\text { for manufactured housing/modular } \\
\text { housing. Low-pitched roofs are a } \\
\text { response to bridge height } \\
\text { restrictions (not pretty). }\end{array}$ & $\begin{array}{l}\text { This is an argument for manufactured housing. The } \\
\text { current perspective, however, is that onsite-assembled } \\
\text { housing is superior to pre-manufactured housing } \\
\text { elements. }\end{array}$ \\
\hline del & 5.15 & mcd & $\begin{array}{l}\text { Design is an issue that lessens the } \\
\text { appeal of manufactured housing. }\end{array}$ & $\begin{array}{l}\text { The problem with manufactured housing is that the } \\
\text { designs are unattractive. }\end{array}$ \\
\hline del & 5.151 & own & $\begin{array}{l}\text { Perhaps should focus all our efforts } \\
\text { on manufactured housing. } \\
\text { Transportation system limits design. } \\
\text { Weather limits design. Site } \\
\text { assembly will continue to exist. }\end{array}$ & $\begin{array}{l}\text { Part of the explanation for that is cost. For example, } \\
\text { the roofs must have a low pitch in order to be } \\
\text { transported cheaply on highways (to pass under } \\
\text { bridges). But they are not pretty. }\end{array}$ \\
\hline del & 5.152 & mcd & (see notes) & $\begin{array}{l}\text { With a traditional home, presumably affordability is not } \\
\text { the primary concern the way it is with manufactured } \\
\text { housing. }\end{array}$ \\
\hline del & 5.153 & bld & (see notes) & $\begin{array}{l}\text { There is a need to expand the testing that is in place, to } \\
\text { streamline it. }\end{array}$ \\
\hline pro & 5.154 & $\mathrm{mfr}$ & (see notes) & $\begin{array}{l}\text { This is true. The issue of time is huge. There must be } \\
\text { quality assurance, but this adds time to the process. It } \\
\text { takes } 17 \text { years to get a patent, and then the company } \\
\text { owns the technology only for a few years. Can't put } \\
\text { more time between patenting and marketing of a } \\
\text { product. Testing must be streamlined to minimize this } \\
\text { time. }\end{array}$ \\
\hline pro & 5.16 & rch & $\begin{array}{l}\text { Are manufacturers willing to take } \\
\text { risk that consumer will buy a higher } \\
\text { priced product? }\end{array}$ & $\begin{array}{l}\text { What are the steps in the introduction of new products? } \\
\text { Does your company introduce new products knowing } \\
\text { that they initially will have a higher cost than the } \\
\text { incumbent, but with adoption, the cost may fall? }\end{array}$ \\
\hline pro & 5.17 & mfr & $\begin{array}{l}\text { Performance should/will pull product } \\
\text { to higher production volume, } \\
\text { reducing cost. Many of our } \\
\text { innovations look closely at a minor } \\
\text { portion of costs (e.g. flashing for } \\
\text { windows). }\end{array}$ & $\begin{array}{l}\text { Yes, most of our products are like this. Take flashing } \\
\text { as an example. We produce a better product that is } \\
\text { highest performing. The idea is that the customer gets } \\
\text { what he or she pays for. So the product is more } \\
\text { expensive on a first cost basis. The company conducts } \\
\text { market research to value the products under } \\
\text { development. As more users come on, the cost will } \\
\text { flatten and there will be labor savings in general as time } \\
\text { goes on. }\end{array}$ \\
\hline pro & 5.171 & mcd & (see notes) & $\begin{array}{l}\text { This flashing, if I am thinking about the one you are } \\
\text { talking about, involves some labor savings in } \\
\text { installation and involves more foolproof installation as } \\
\text { well. }\end{array}$ \\
\hline pro & 5.172 & $\mathrm{mfr}$ & (see notes) & $\begin{array}{l}\text { An additional factor is that flashing does not represent } \\
\text { a high percentage of the price of an entire window } \\
\text { package. }\end{array}$ \\
\hline pro & 5.18 & own & $\begin{array}{l}\text { We must determine what the } \\
\text { tendencies to failure are and test } \\
\text { those aspects of the product. }\end{array}$ & $\begin{array}{l}\text { There is a three-stage process. As Donald Rumsfeld } \\
\text { said, the worst thing is the "unknown unknown." }\end{array}$ \\
\hline pro & 5.181 & $\mathrm{mfr}$ & (see notes) & My company tests new products for robustness to \\
\hline
\end{tabular}




\begin{tabular}{|c|c|c|c|c|}
\hline 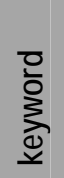 & 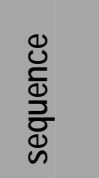 & 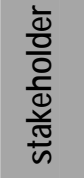 & 'flip chart' record & NIST notes \\
\hline & & & & $\begin{array}{l}\text { installation by brainstorming about possible installation } \\
\text { mistakes, such as picking the six worst ways to mess } \\
\text { something up and try to work with it. Not all companies } \\
\text { will do this. }\end{array}$ \\
\hline del & 5.19 & bld & $\begin{array}{l}\text { Prevent innovation adoption-target } \\
\text { of marketing/product purchase; } \\
\text { decision is 'no' if equal or greater } \\
\text { cost than what it is substituting for. }\end{array}$ & $\begin{array}{l}\text { Manufacturers sometimes target the wrong agent to } \\
\text { promote a product, that is, the purchasing agent, who is } \\
\text { taught to say no if the product costs more. It should be } \\
\text { the sales and marketing folks. }\end{array}$ \\
\hline del & 5.191 & $\mathrm{mfr}$ & (see notes) & $\begin{array}{l}\text { The problem is potentially worse if there is a value } \\
\text { chain. The retailer may not want to take a risk on } \\
\text { stocking an item if it does not know whether the } \\
\text { subcontractor will want it. }\end{array}$ \\
\hline del & 5.192 & bld & $\begin{array}{l}\text { Retailer may not want to stock (e.g. } \\
\text { additional sked space/sku's). New } \\
\text { technology often must completely } \\
\text { replace something already out } \\
\text { there. Tough sell. }\end{array}$ & $\begin{array}{l}\text { Also, a new product is another SKU number that the } \\
\text { retailer will have to keep track of for inventory. } \\
\text { Retailers resist change. }\end{array}$ \\
\hline att & 5.20 & own & $\begin{array}{l}\text { Standard of acceptance-code } \\
\text { compliance/acceptance is very } \\
\text { important. }\end{array}$ & $\begin{array}{l}\text { Without thinking about it, house buyers are hyper- } \\
\text { conservative about new innovations. For them, } \\
\text { perception is reality. What matters is cost, location, } \\
\text { and style. They trust the code without exploring it. } \\
\text { Normally house buyers are happy enough assuming } \\
\text { that the code has been followed and that this } \\
\text { constitutes safety. If they see an innovation being } \\
\text { used, however, then it will raise their concern about its } \\
\text { code adherence. }\end{array}$ \\
\hline pro & 5.21 & mcd & $\begin{array}{l}\text { For new products: } \\
\text { - Manufacturer } \\
\text { underestimate risk } \\
\text { - Consumer will overestimate } \\
\text { risk } \\
\text { - Both will try to shift risk to } \\
\text { someone else } \\
\text { - Ultimate consumer probably } \\
\text { least able to afford risk } \\
\text { Is there a way to get better } \\
\text { information to all? }\end{array}$ & $\begin{array}{l}\text { There are three problems: } \\
\text { 1. Manufacturers champion new products and } \\
\text { underestimate the risk. } \\
\text { 2. Homeowners overestimate the risk of new products. } \\
\text { 3. All hope risk will fall on someone else, to displace } \\
\text { the risk to another party. } \\
\text { To address the question, must address all three } \\
\text { problems, not just any one. The sufferer of problem \#3 } \\
\text { will probably end up being the homeowner. Is there a } \\
\text { better way to address risk? }\end{array}$ \\
\hline pro & 5.211 & reg & (see notes) & $\begin{array}{l}\text { Is there a way to have groups look more objectively at } \\
\text { innovations? }\end{array}$ \\
\hline pro & 5.212 & $\mathrm{mfr}$ & (see notes) & $\begin{array}{l}\text { To go back to the auto analogy, one factor there is } \\
\text { ease of recall. In the building industry, there is not an } \\
\text { easy recall system. If a builder or manufacturer sent } \\
\text { out a notice, it would probably be faced with lawsuits. } \\
\text { This makes the issue of trying to implement new } \\
\text { innovations more difficult. }\end{array}$ \\
\hline pro & 5.213 & bld & (see notes) & $\begin{array}{l}\text { Homes are more heterogeneous than cars. This } \\
\text { makes recall more difficult. }\end{array}$ \\
\hline pro & 5.214 & mcd & (see notes) & $\begin{array}{l}\text { Also, component manufacturers are shallow pockets. } \\
\text { They can't afford to pay for recalls. }\end{array}$ \\
\hline pro & 5.215 & rch & (see notes) & Need risk insurance or vertical integration. \\
\hline
\end{tabular}




\begin{tabular}{|c|c|c|c|c|}
\hline 产 & 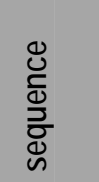 & 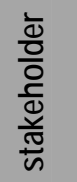 & 'flip chart' record & NIST notes \\
\hline bar & 5.22 & bld & $\begin{array}{l}\text { Big problem for builder is how to } \\
\text { train producers/installers (laborers); } \\
\text { ability to train will be a big } \\
\text { component of acceptance. (internet } \\
\text { opportunity?) }\end{array}$ & $\begin{array}{l}\text { Need education/training and uniform installation. There } \\
\text { is a lack of consensus about the proper method. The } \\
\text { ability to train is not there. How can this training be } \\
\text { delivered? Must simplify delivery of content (such as } \\
\text { through the Internet). }\end{array}$ \\
\hline bar & 5.221 & $\mathrm{mcd}$ & (see notes) & $\begin{array}{l}\text { The earlier idea of an engineered, integrated solution } \\
\text { would get around this problem. }\end{array}$ \\
\hline bar & 5.23 & rch & $\begin{array}{l}\text { Labor problems have only gotten } \\
\text { worse over last } 40 \text { years. }\end{array}$ & $\begin{array}{l}\text { The labor problem has only gotten worse and will } \\
\text { continue to do so. }\end{array}$ \\
\hline per & 5.231 & reg & (see notes) & $\begin{array}{l}\text { Is there a way to have groups look more objectively at } \\
\text { innovations? }\end{array}$ \\
\hline bar & 5.232 & $\mathrm{mfr}$ & (see notes) & $\begin{array}{l}\text { There is no effective recall system for homes. This } \\
\text { makes the issue of trying to implement new innovations } \\
\text { more difficult. }\end{array}$ \\
\hline bar & 5.24 & bld & $\begin{array}{l}\text { Supply-chain liability will/should fix } \\
\text { problem. }\end{array}$ & $\begin{array}{l}\text { It is the supply chain that will eventually improve the } \\
\text { testing and research situations. The solution must be } \\
\text { found in the supply and distribution chain because that } \\
\text { is where the liability lies. It is where the supply and } \\
\text { labor interface. There has been a decline of vocational } \\
\text { training in the U.S. It has been taken out of high } \\
\text { schools. The unions are not providing or requiring it. } \\
\text { They do not know how to put things in. So who will } \\
\text { benefit from labor improvements? Use the supply } \\
\text { chain as a risk management method. }\end{array}$ \\
\hline att & 5.25 & $\mathrm{mcd}$ & $\begin{array}{l}\text { Other industries focus on QC- } \\
\text { McDonalds. }\end{array}$ & $\begin{array}{l}\text { McDonalds is an example of an organization that has } \\
\text { managed to achieve quality control and labor } \\
\text { standardization across many countries, cultures, and } \\
\text { languages. }\end{array}$ \\
\hline bar & 5.26 & cst & $\begin{array}{l}\text { Over-emphasis of regulated side of } \\
\text { costs; should we shift focus to non- } \\
\text { regulated side? We no longer invest } \\
\text { in basic research. }\end{array}$ & $\begin{array}{l}\text { There is insufficient basic research in the public sector } \\
\text { that leads to innovation. Also, have to look at the } \\
\text { unregulated components of housing. }\end{array}$ \\
\hline per & 5.27 & $\mathrm{mfr}$ & $\begin{array}{l}\text { Applied research is done well } \\
\text { privately; basic research is no } \\
\text { longer being done by the feds. }\end{array}$ & (see record) \\
\hline per & 5.28 & $\mathrm{mcd}$ & Worldwide problem. & $\begin{array}{l}\text { This is a global phenomenon. Almost all the fire labs in } \\
\text { the world are now privatized. }\end{array}$ \\
\hline per & 5.281 & cst & (see notes) & $\begin{array}{l}\text { Just look at old National Bureau of Standards (NBS) } \\
\text { publications. It used to all be basic research. }\end{array}$ \\
\hline per & 5.29 & rch & $\begin{array}{l}\text { Housing improvement has never } \\
\text { been an objective of government. }\end{array}$ & $\begin{array}{l}\text { With agriculture, the public sector funds a great deal of } \\
\text { basic research, with the motivation and rationale that } \\
\text { what benefits the farmers will benefit society. Except } \\
\text { for Operation Breakthrough in 1968-1972, there has } \\
\text { been a lack of motivation in the case of building } \\
\text { research parallel to agriculture. }\end{array}$ \\
\hline att & 5.30 & cst & $\begin{array}{l}\text { When they say "affordability", } \\
\text { respond with "basic research". Even } \\
\text { basic "affordability" is beyond code } \\
\text { compliance requirements. }\end{array}$ & $\begin{array}{l}\text { As a country, we do not invest much in basic research } \\
\text { and testing in the housing industry (in the public } \\
\text { sector). In general, basic affordability is beyond the } \\
\text { code minimums. } \\
\text { We have to keep in mind that nobody would buy a }\end{array}$ \\
\hline
\end{tabular}




\begin{tabular}{|c|c|c|c|c|}
\hline 힣 & 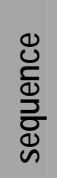 & 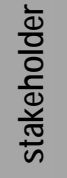 & 'flip chart' record & NIST notes \\
\hline & & & & $\begin{array}{l}\text { code-minimum house. Such a house has no wall } \\
\text { board, no paint, no carpet. The market prevents code- } \\
\text { minimum houses. Most of the affordability equation is } \\
\text { beyond the code. Therefore, must look at the } \\
\text { unregulated component of housing. }\end{array}$ \\
\hline
\end{tabular}

Discussion session \#6: How should society value or monetize the social costs and benefits of introducing technology in residential housing, such as energy conservation or disaster relief and recovery, at both scales? What happens when you add social costs and benefits to the discussion?

\begin{tabular}{|c|c|c|c|c|}
\hline 힣 & 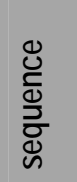 & $\begin{array}{l}\frac{\bar{d}}{0} \\
\frac{0}{0} \\
\frac{0}{d} \\
\frac{\vec{J}}{\omega}\end{array}$ & 'flip chart' record & NIST notes \\
\hline per & 6.01 & fin & $\begin{array}{l}\text { There is a difference between } \\
\text { 'valuing' and 'monetizing' } \\
\text { In terms of stakeholder values- } \\
\text { there is difference between 'general } \\
\text { stakeholders' (e.g. regulators and } \\
\text { repairmen) and 'stakeholders with } \\
\text { standing' } \\
\text { In terms of distribution of costs and } \\
\text { benefits-FNMA is far more } \\
\text { concerned with negative impacts on } \\
\text { low-income segments (much more } \\
\text { susceptible to adverse effects) } \\
\text { In terms of social costs-at what } \\
\text { geographic/political level are they } \\
\text { considered? } \\
\text { Social value is highly subjective- } \\
\text { New York City studied costs that } \\
\text { accrued to the city-city bore costs } \\
\text { disproportionately; benefits were } \\
\text { more widespread. How do you value } \\
\text { benefits like self-esteem? }\end{array}$ & $\begin{array}{l}\text { - Is it possible to make a quantitative judgment } \\
\text { based on a qualitative factor? } \\
\text { - Should regulators be considered stakeholders? } \\
\text { They are not necessarily stakeholders when } \\
\text { considering costs. } \\
\text { - Do you consider costs to repairmen as new } \\
\text { technologies are implemented? } \\
\text { - Fannie Mae is concerned with regulations having } \\
\text { negative impacts towards low-income housing } \\
\text { (crime, education). Fannie Mae is more interested } \\
\text { in increased cost on lower income families - this is } \\
\text { the group where negative externalities are } \\
\text { greatest. } \\
\text { For social costs and benefits, you need to know } \\
\text { what area you are talking about? Every } \\
\text { stakeholder places different values on social } \\
\text { costs. Every person/place places a different value } \\
\text { on a social outcome. } \\
\text { Cost savings on criminal justice system in New } \\
\text { York City is support of housing for the homeless } \\
\text { was instated - how do you determine the value of } \\
\text { a quality like self-esteem? No value for self- } \\
\text { esteem has been determined for giving shelter to } \\
\text { the homeless. }\end{array}$ \\
\hline per & 6.02 & reg & $\begin{array}{l}\text { Complete re-write of state building } \\
\text { codes has been done-touches on } \\
\text { issues of how to value innovation in } \\
\text { housing. } \\
\text { - Agree that regulators are not a } \\
\text { direct stakeholder, in terms of } \\
\text { costs and benefits, but key } \\
\text { player/actors. }\end{array}$ & $\begin{array}{l}\text { - How does society value innovation? } \\
\text { - New York State recently updated/changed building } \\
\text { - } \quad \text { Godes } \\
\text { is to strike a balance and express this through } \\
\text { building codes. } \\
\text { - } 1984 \text { - the New York Code Council turned its back } \\
\text { for almost } 16 \text { years on the public's needs by not }\end{array}$ \\
\hline
\end{tabular}




\begin{tabular}{|c|c|c|c|c|}
\hline 离 & 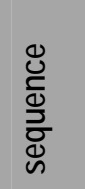 & 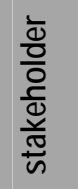 & 'flip chart' record & NIST notes \\
\hline & & & $\begin{array}{l}\text { - State looked to balance costs } \\
\text { and benefits that 'mandated' or } \\
\text { 'incentivized'-must be done in } \\
\text { cooperation with industry and } \\
\text { society. The code was last } \\
\text { revamped in } 1984 \text { and industry } \\
\text { had grown beyond it; it became } \\
\text { an impediment to building with } \\
\text { the state. } \\
\text { Effectiveness of 'incentive' } \\
\text { 'regulation/mandate': government } \\
\text { must determine threshold based on } \\
\text { true and perceived risk or lose } \\
\text { public trust. } \\
\text { Public will reject increased cost until } \\
\text { they recognize benefit, then they will } \\
\text { embrace action } \\
\text { Public does not want to pay more } \\
\text { for a 'mandated' action. }\end{array}$ & $\begin{array}{l}\text { considering new technologies. The council } \\
\text { became obsolete because of not keeping up with } \\
\text { trends. Government and society must work } \\
\text { together. } \\
\text { - Incentives vs. regulations: if government regulates } \\
\text { without input, they lose public trust. } \\
\text { - An incentive-based environment would give the } \\
\text { public time to place a value on technology. } \\
\text { Mandated regulations are rejected by the public } \\
\text { because they are likely to increase costs across } \\
\text { the board. }\end{array}$ \\
\hline att & 6.03 & mcd & $\begin{array}{l}\text { Different take on session, based } \\
\text { primarily on an economic } \\
\text { discussion-maximizing wealth (of } \\
\text { the community) through } \\
\text { regulation/incentives that address } \\
\text { factors which are not obvious and } \\
\text { visible-"internalization of of } \\
\text { externalities". }\end{array}$ & $\begin{array}{l}\text { The presence of externalities leads to the need to } \\
\text { create a pricing system more in keeping with social } \\
\text { costs (monetizing social costs) so that the externalities } \\
\text { are internalized. Under an ideal situation, society } \\
\text { makes choices, and through these choices, the best } \\
\text { pricing will occur for society as a whole. For example, } \\
\text { the price of solid waste does not include the cost to } \\
\text { society of its disposal, so a person making a purchase } \\
\text { choice does not have to consider the cost of disposal in } \\
\text { his decision. An alternative to incentives is regulation. } \\
\text { The downside of regulation is that it is a static system, } \\
\text { and will not create incentives to innovate around the } \\
\text { (negative) externalities. You're prohibiting or directing } \\
\text { actions. }\end{array}$ \\
\hline seg & 6.04 & rch & $\begin{array}{l}\text { We have not articulated the } \\
\text { differences between SF and MF } \\
\text { delivery. MF internalizes external } \\
\text { costs for many actors. It is the } \\
\text { difference between a private } \\
\text { transaction and a public transaction. } \\
\text { Additional R\&D on the private side } \\
\text { may be an effective approach. } \\
\text { Removal of barriers to innovation is } \\
\text { another. }\end{array}$ & $\begin{array}{l}\text { Multi-family housing does best at internalizing (Fannie } \\
\text { Mae). Because it is an investment, there is an } \\
\text { incentive for long-term concern on the part of mortgage } \\
\text { lenders. With single-family housing, the issue is } \\
\text { creditworthiness, so this incentive to have concern } \\
\text { about the long term is not there. Monetizing social } \\
\text { benefits becomes irrelevant. Need to determine the } \\
\text { constraints that exist in the housing system and get } \\
\text { them out of the way. Regulators should not be a } \\
\text { stakeholder group. They should be surrogates. To } \\
\text { what degree is the regulatory system a barrier to } \\
\text { innovation? How can the regulatory system improve } \\
\text { the health and safety of individuals? One proposal is to } \\
\text { provide the council of evaluations a more } \\
\text { comprehensive evaluation system to better know these } \\
\text { costs to those with long-term financial interests. With } \\
\text { single-family homes, these are private, unregulated }\end{array}$ \\
\hline
\end{tabular}




\begin{tabular}{|c|c|c|c|c|}
\hline 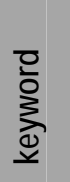 & 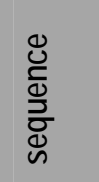 & 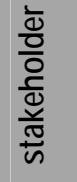 & 'flip chart' record & NIST notes \\
\hline & & & & $\begin{array}{l}\text { transactions between two parties that do not have long- } \\
\text { term financial interests. It is very different from multi- } \\
\text { family housing. }\end{array}$ \\
\hline seg & 6.05 & rch & $\begin{array}{l}\text { No, we should not use MF as the } \\
\text { model-we should employ taxes, } \\
\text { fees, and fines for } 5 \text { year first use } \\
\text { and } 20 \text { year expected service life (it } \\
\text { realistically may be } 100 \text { years) }\end{array}$ & $\begin{array}{l}\text { Decoupling the product from the credit to pay for it } \\
\text { leads to this outcome. If a durability fee were to get } \\
\text { added to the production function, then will capture the } \\
\text { costs to society. }\end{array}$ \\
\hline seg & 6.051 & rch & (see notes) & This would not get done without regulation. \\
\hline per & 6.06 & bld & $\begin{array}{l}\text { Goes back to question of distribution } \\
\text { of benefits-need innovation not in } \\
\text { widgets and hard things, but in } \\
\text { regulation-opportunities in } \\
\text { implementation of rehab codes. } \\
\text { The entrepreneur sees opportunity, } \\
\text { takes risk, should benefit-there has } \\
\text { been a } 40 \% \text { increase in permits } \\
\text { since implementation of the New } \\
\text { Jersey Rehabilitation Code } \\
\text { (primarily in vacant urban, mature } \\
\text { suburban, and decaying rural } \\
\text { properties) }\end{array}$ & $\begin{array}{l}\text { The key is the distribution of benefits, as a participant } \\
\text { suggested. The beneficiaries of rehab codes may not } \\
\text { be society. They may go to the private sector, such as } \\
\text { entrepreneurs. For example, risk takers buy low and } \\
\text { sell at higher market value. There are three places } \\
\text { where older buildings are found: urban, suburban, and } \\
\text { rural. This has happened with change in the New } \\
\text { Jersey Rehabilitation Code, because barriers were } \\
\text { removed and the regulatory system changed to allow } \\
\text { these innovations. }\end{array}$ \\
\hline bar & 6.07 & rch & $\begin{array}{l}\text { Should we remove regulatory } \\
\text { intervention? There are too many } \\
\text { gatekeepers; find other ways to } \\
\text { protect buyers, such as "builders } \\
\text { insurance"? }\end{array}$ & $\begin{array}{l}\text { The change in the regulations is key. There are too } \\
\text { many gatekeepers. We should try to remove as many } \\
\text { barriers as possible. If there is a valid program of } \\
\text { builders' insurance and consumer product safety, then } \\
\text { the regulations can be scaled back. }\end{array}$ \\
\hline seg & 6.08 & $\mathrm{mcd}$ & $\begin{array}{l}\text { This is not the topic for this session; } \\
\text { we should discuss, for example, } \\
\text { 'redevelopment' } \\
\begin{array}{ll}\text { development' } & \text { v. 'new }\end{array} \\
\end{array}$ & $\begin{array}{l}\text { We need to shift back. Infrastructure and social } \\
\text { services are examples of social costs that are truly } \\
\text { borne by the beneficiaries. }\end{array}$ \\
\hline seg & 6.081 & rch & (see notes) & Impact fees can capture these costs. \\
\hline bar & 6.09 & rch & $\begin{array}{l}\text { We should be looking at incentives } \\
\text { (for solar, flood, hazard mitigation, } \\
\text { etc.) based on social benefits and } \\
\text { costs. }\end{array}$ & $\begin{array}{l}\text { There are incentives for social costs and benefits at the } \\
\text { level of individual homeowners in some areas, such as } \\
\text { for weather hazards. For example, the homeowners } \\
\text { would only be eligible for flood insurance if they took } \\
\text { certain precautions. It is also necessary to focus on } \\
\text { owner-occupied housing. }\end{array}$ \\
\hline seg & 6.091 & rch & (see notes) & $\begin{array}{l}\text { We can't apply lessons from multifamily housing to } \\
\text { single-family housing. }\end{array}$ \\
\hline bar & 6.10 & bld & $\begin{array}{l}\text { We should focus on positive } \\
\text { incentives, like tax credits, etc. } \\
\text { Mitigation is purely regulation } \\
\text { Insurance companies have an } \\
\text { opportunity to reduce their own risk } \\
\text { through risk-based underwriting } \\
\text { (encourage rather than force } \\
\text { acceptance) }\end{array}$ & $\begin{array}{l}\text { There are government incentives, including tax credits } \\
\text { and land use (higher density, cost of land). Some of } \\
\text { the mitigation that was just described is mandatory, not } \\
\text { incentive-based. Insurance can provide incentives with } \\
\text { lower premiums in some areas to reflect risk, but it is } \\
\text { regulated by states. States have an opportunity to } \\
\text { affect this. We need a metric to measure these } \\
\text { technologies (which one is better?). Social benefits will } \\
\text { come from what the government recognizes as } \\
\text { important (for example, provide a free thermostat). }\end{array}$ \\
\hline
\end{tabular}




\begin{tabular}{|c|c|c|c|c|}
\hline 产 & 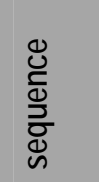 & 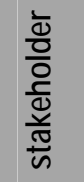 & 'flip chart' record & NIST notes \\
\hline & & & & Encourage, rather than enforce, through different costs. \\
\hline bar & 6.11 & cst & $\begin{array}{l}\text { We need to ask why we are } \\
\text { concerned with social costs: } \\
\text { - } 3 \text { rd party effects are fair } \\
\text { game for incentives } \\
\text { - } \text { Mandates should not be } \\
\text { based on externalities } \\
\text { - Externalities should be } \\
\text { viewed very skeptically. }\end{array}$ & $\begin{array}{l}\text { Why are we even trying to monetize costs and } \\
\text { benefits? There are two extreme motivations. The first } \\
\text { is to promote technology development with enlightened } \\
\text { policies. If we are trying to do this, then monetize costs } \\
\text { and benefits. The second is to provide justification for } \\
\text { more regulations. If this is the case, then will lead to } \\
\text { more skepticism. A problem is that everything is an } \\
\text { externality. They can be seen everywhere, and the } \\
\text { exercise of monetizing them would never end. In any } \\
\text { case, with regard to the example of solid waste } \\
\text { disposal, I have to pay a waste disposal fee every year. }\end{array}$ \\
\hline bar & 6.111 & fin & (see notes) & $\begin{array}{l}\text { But the cost of the disposal is not internalized at the } \\
\text { time of purchase of the product because the purchase } \\
\text { price is separate from the end-of-year disposal fee. }\end{array}$ \\
\hline bar & 6.12 & mcd & $\begin{array}{l}\text { We need to address issues in terms } \\
\text { of economic and government } \\
\text { regulation theory }\end{array}$ & $\begin{array}{l}\text { Often the disposal fee is a flat fee and does not depend } \\
\text { on the volume of trash generated. This is a justification } \\
\text { for regulations. Regulations are used to adjust and } \\
\text { compensate for the fact that "natural costing" does not } \\
\text { automatically account for all costs. }\end{array}$ \\
\hline bar & 6.13 & cst & $\begin{array}{l}\text { Regulation is often an adaptation to } \\
\text { real circumstances }\end{array}$ & $\begin{array}{l}\text { We need to focus on reforming regulations which } \\
\text { improve affordability for everybody, not just removing } \\
\text { regulations. }\end{array}$ \\
\hline bar & 6.131 & rch & (see notes) & $\begin{array}{l}\text { With the New Jersey Rehabilitation Code, reforms } \\
\text { turned out to have the same effect as removal. It } \\
\text { lightened the burden. }\end{array}$ \\
\hline bar & 6.132 & cst & (see notes) & $\begin{array}{l}\text { The assumption in code reform is that the original } \\
\text { regulations were right. }\end{array}$ \\
\hline bar & 6.133 & rch & (see notes) & $\begin{array}{l}\text { It is possible to internalize externalities in many ways, } \\
\text { such as tax credits, insurance incentives. Do we want } \\
\text { to do it all? }\end{array}$ \\
\hline met & 6.14 & fin & $\begin{array}{l}\text { How do you choose between } \\
\text { regulation and not-you need a } \\
\text { metric to decide. }\end{array}$ & $\begin{array}{l}\text { Assume that technology produces some good. What is } \\
\text { the metric to link these two? }\end{array}$ \\
\hline met & 6.15 & mcd & $\begin{array}{l}\text { Peer pressure, education, and } \\
\text { branding may be the most effective } \\
\text { options; example of 'ruffs' and 'riffs' } \\
\text { (resource utilization v. resource } \\
\text { impact, such as embodied energy } \\
\text { metric) precursor to energy codes. } \\
\text { Created huge battle between } \\
\text { electric and gas (in terms of BTUs } \\
{[1055 \text { joules]). Could not drive }} \\
\text { technical decision because of lack } \\
\text { of agreement on parameters. } \\
\text { Upshot is that players cannot plan } \\
\text { on staying power of analysis. }\end{array}$ & $\begin{array}{l}\text { Another incentive is branding, labeling, reputation. } \\
\text { There is an example from many years ago from energy: } \\
\text { RUF (resource utilization factor) vs. RIF (resource } \\
\text { impact factor). NIST wrote a way to compare the } \\
\text { energy performance of different alternatives. The } \\
\text { energy codes created a gas/electric battle. The } \\
\text { question arose as to whether should count BTU (1 } 055 \\
\text { joules) at the source. The RUF was computed as the } \\
\text { reciprocal of plant energy usage. The RIF was needed } \\
\text { because not all BTUs are the same. It needed to be } \\
\text { based on "embodied" energy as well as all social costs } \\
\text { and benefits, such as sustainability, health care, etc. } \\
\text { This effort fell apart and died because it could not drive } \\
\text { a technical decision, and everything was valued } \\
\text { differently. Could look at this question by costs. The } \\
\text { problem is that the price does not reflect social costs. }\end{array}$ \\
\hline
\end{tabular}




\begin{tabular}{|c|c|c|c|c|}
\hline 高 & 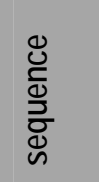 & 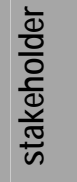 & 'flip chart' record & NIST notes \\
\hline & & & & $\begin{array}{l}\text { Need to pass the burden of determining social costs to } \\
\text { Department of Energy. These values change and } \\
\text { make the designs, regulations, etc. obsolete. }\end{array}$ \\
\hline val & 6.16 & bld & $\begin{array}{l}\text { Question remains how to value a } \\
\text { parameter in order to have a basis } \\
\text { to set a fee-the consumer views } \\
\text { the product (housing) as a durable } \\
\text { asset, internalizing ALL perceived } \\
\text { costs. }\end{array}$ & $\begin{array}{l}\text { This obsolescence only applies to regulations. With } \\
\text { incentives, people will adapt. How do you assign value } \\
\text { to these? }\end{array}$ \\
\hline val & 6.17 & mfr & $\begin{array}{l}\text { Each consumer (including speaker) } \\
\text { uses own set of values and beliefs } \\
\text { in personal decision-making. }\end{array}$ & $\begin{array}{l}\text { Values differ from individual to individual, based on } \\
\text { their own life experiences. Heterogeneity makes } \\
\text { valuing these social costs and benefits difficult, even } \\
\text { impossible. }\end{array}$ \\
\hline met & 6.18 & bld & $\begin{array}{l}\text { The issue is a mathematical } \\
\text { problem and not that difficult to } \\
\text { understand: value of stock } \\
\text { measured in trillions of dollars, } \\
\text { divided by the number of units, plus } \\
\text { annual cost of maintaining times } \\
\text { service life, divided by service life } \\
\text { equals annual cost of ownership. }\end{array}$ & $\begin{array}{l}\text { The incentive is to push durability by distributing first } \\
\text { cost. When R\&D comes in, it will be implemented more } \\
\text { easily. Longevity is the missing piece. There are no } \\
\text { data projecting durability or longevity of housing. } \\
\text { propose a formula to compute the annual cost of } \\
\text { ownership of a home which falls with the longevity of } \\
\text { the home: annual cost = (initial cost + maintenance + } \\
\text { operating costs)/longevity of the home. It disperses the } \\
\text { first cost over a longer time horizon. The social cost } \\
\text { that is reduced with increase in longevity is the need to } \\
\text { rebuild "10 year" homes every ten years. }\end{array}$ \\
\hline met & 6.19 & bld & $\begin{array}{l}\text { Concept makes a lot of sense } \\
\text { except for characterization as } \\
\text { "simple" problem-we do not know } \\
\text { how long housing lasts. Pricing in } \\
\text { durability may be useful, but may } \\
\text { not. }\end{array}$ & $\begin{array}{l}\text { The problem is that this would not be simple because } \\
\text { we do not know how long the housing stock lasts to } \\
\text { develop a meaningful relationship based on durability. } \\
\text { The government does not collect data on component } \\
\text { changes or demolition permits anymore. Therefore, we } \\
\text { do not know. We would have to overcome a credibility } \\
\text { problem with the consumer. }\end{array}$ \\
\hline per & 6.191 & bld & (see notes) & $\begin{array}{l}\text { The stakeholder has a stake in making the component } \\
\text { last. }\end{array}$ \\
\hline met & 6.20 & rch & $\begin{array}{l}\text { Like elegance of relying on } \\
\text { mathematical formula, but how do } \\
\text { you factor in uncertainty of } \\
\text { manufacturer claims. }\end{array}$ & $\begin{array}{l}\text { The consumer or the manufacturer? We need data on } \\
\text { reliability. For example, my " } 20 \text { year roof" had to be } \\
\text { replaced after only } 4 \text { years. }\end{array}$ \\
\hline met & 6.201 & bld & (see notes) & $\begin{array}{l}\text { Without a durability rating index, a bunch of } \\
\text { disconnected people only see the first costs. There } \\
\text { needs to be some linkage between them. }\end{array}$ \\
\hline met & 6.202 & mcd & (see notes) & $\begin{array}{l}\text { Not all social costs and benefits lend themselves to } \\
\text { time-to-repair metrics. But for those that do, this index } \\
\text { would be great. }\end{array}$ \\
\hline met & 6.203 & bld & (see notes) & $\begin{array}{l}\text { Who enforces this formula? It should be the } \\
\text { underwriting industry. }\end{array}$ \\
\hline met & 6.204 & cst & (see notes) & Like fuel efficiency for automobiles. \\
\hline per & 6.21 & cst & $\begin{array}{l}\text { Many stakeholders have an } \\
\text { inordinate fear of regulation }\end{array}$ & $\begin{array}{l}\text { NIST developed durability performance standards } \\
\text { purely based on technical considerations. It led to } \\
\text { paranoia. This was fought by, among others, } \\
\text { homebuilders, at ASTM meetings. }\end{array}$ \\
\hline
\end{tabular}




\begin{tabular}{|c|c|c|c|c|}
\hline & 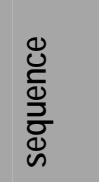 & 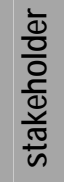 & 'flip chart' record & NIST notes \\
\hline per & 6.211 & rch & (see notes) & $\begin{array}{l}\text { The paranoia is justified because the fear is that an } \\
\text { intellectual exercise will lead to the easy "fallback" } \\
\text { approach: regulation. }\end{array}$ \\
\hline per & 6.212 & bld & (see notes) & $\begin{array}{l}\text { Even with an index, the consumer may still ignore it. If } \\
\text { this happened, it would prompt regulation. }\end{array}$ \\
\hline met & 6.22 & fin & $\begin{array}{l}\text { The durability equation as outlined } \\
\text { does not address social costs (the } \\
\text { key parameter of this session). }\end{array}$ & $\begin{array}{l}\text { The equation also would not address social costs, such } \\
\text { as environmental costs. }\end{array}$ \\
\hline met & 6.23 & bld & (see notes) & There would be trouble monetizing these social costs. \\
\hline met & 6.24 & bld & (see notes) & $\begin{array}{l}\text { The formula is already done in a quasi-method. The } \\
\text { buyer gets information about the age of the roof, energy } \\
\text { costs, etc. of the prospective home. }\end{array}$ \\
\hline
\end{tabular}

Discussion session \#7: Can the regulatory system be used to encourage innovation, and to distinguish innovations with net benefits from those with net costs, at both component scale and at the scale of the entire house and its delivery system?

\begin{tabular}{|c|c|c|c|c|}
\hline 잏 & 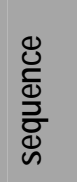 & 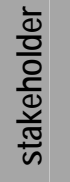 & 'flip chart' record & NIST notes \\
\hline att & 7.01 & $\mathrm{mcd}$ & $\begin{array}{l}\text { Most regulation is intended to } \\
\text { advance not affordability, but some } \\
\text { other factor, primarily safety. Many } \\
\text { regulators want to trust what they } \\
\text { know works-prescriptive } \\
\text { standards-feeling that performance } \\
\text { approaches may undercut } \\
\text { effectiveness of standards and may } \\
\text { be more difficult to evaluate. } \\
\text { Innovation may exacerbate } \\
\text { performance-based evaluation } \\
\text { concerns. In addition, lack of a } \\
\text { common language is a problem- } \\
\text { economists and policy makers want } \\
\text { to express all concerns in dollars. } \\
\text { Key point is that we don't need less, } \\
\text { we need better regulation-the } \\
\text { advocated approach favors } \\
\text { modeling, yielding "smart regulation } \\
\text { audited with civility" }\end{array}$ & $\begin{array}{l}\text { - Prescriptive requirements are antagonistic towards } \\
\text { new innovations. } \\
\text { - } 2 \text { ways of employing materials: To trust what you } \\
\text { know works is prescriptive and to prove it works is } \\
\text { performance based. } \\
\text { o performance approach: test new } \\
\text { technologies; there is no long-term field } \\
\quad \text { experience. } \\
\text { prescriptive approach; trust what you } \\
\text { know works } \\
\text { - Performance approach is difficult: does not always } \\
\text { consider reliability. If you open up requirements, } \\
\text { you may introduce unreliability. } \\
\text { If you only allow performance equivalence for } \\
\text { components, not for a whole design, you limit how } \\
\text { innovative a product you'll consider, but you also } \\
\text { limit how far from common experience and } \\
\text { comfort-zone you have to go. } \\
\text { - Lack of a common language -- not everyone is } \\
\text { comfortable expressing everything in money terms } \\
-- \text { is a barrier to acceptance of performance } \\
\text { approach. } \\
\text { Economics measures costs. We need different } \\
\text { regulation. Flexibility is where we want to go. } \\
\text { We want flexibility in achieving social objectives }\end{array}$ \\
\hline
\end{tabular}




\begin{tabular}{|c|c|c|c|c|}
\hline 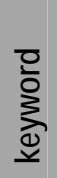 & 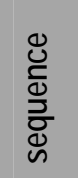 & 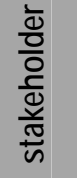 & 'flip chart' record & NIST notes \\
\hline & & & & $\begin{array}{l}\text { (the enforcers' role) in ways that are more } \\
\text { affordable or better in other ways. That means } \\
\text { different regulations but is not a reason to make all } \\
\text { decisions purely economic decisions. }\end{array}$ \\
\hline att & 7.02 & $\mathrm{mcd}$ & $\begin{array}{l}\text { Factors must be identified and } \\
\text { explored. Should such a system be } \\
\text { a basis for regulation? What is } \\
\text { needed is a baseline level to } \\
\text { exceed. For life-safety issues, codes } \\
\text { and standards typically lag } \\
\text { technology development. If non- } \\
\text { prescriptive, there is no information } \\
\text { on which to base approval/ } \\
\text { acceptance. } \\
\text { Washington Post column on } \\
\text { regulation cites } 3 \text { needs: } \\
\text { - Information based on good } \\
\text { research } \\
\text { - Ability to defend analysis tools } \\
\text { - Implementation policies that } \\
\text { encourage smart life-saving } \\
\text { analyses }\end{array}$ & $\begin{array}{l}\text { - We can encourage innovation, but the manner in } \\
\text { which this will happen must be carefully } \\
\text { considered. It leads to the regulatory system } \\
\text { making decisions. Whoever is using the } \\
\text { innovation makes the decision. } \\
\text { - Establish the minimums at the state level: this } \\
\text { baseline will establish a framework for } \\
\text { considerations of new materials. } \\
\text { - Codes/standards tend to lag technological } \\
\text { developments. } \\
\text { - In the absence of specific technology references in } \\
\text { the code, it is more difficult to implement the } \\
\text { technology. }\end{array}$ \\
\hline bar & 7.03 & own & $\begin{array}{l}\text { Las Vegas as a model-regulators } \\
\text { must be open-minded to allow range } \\
\text { of designs in place }\end{array}$ & Regulators need to play a major role. \\
\hline bar & 7.04 & mcd & $\begin{array}{l}\text { Codes must be a mix of prescriptive } \\
\text { and performance-based } \\
\text { requirements to avoid 'first-time' } \\
\text { pitfalls (redundancy/alternatives?) }\end{array}$ & $\begin{array}{l}\text { Prescriptive codes require regulators to be very } \\
\text { knowledgeable and sophisticated enough to adapt to } \\
\text { changing technology. With PBC (performance-based } \\
\text { codes), on the other hand, there is no stable ground. } \\
\text { Therefore, we need some middle ground. Australia and } \\
\text { New Zealand are examples. }\end{array}$ \\
\hline bar & 7.05 & rch & $\begin{array}{l}\text { Do we have any evidence that more } \\
\text { innovation occurs under one or the } \\
\text { other scheme of regulation } \\
\text { (performance versus prescriptive } \\
\text { codes)? }\end{array}$ & $\begin{array}{l}\text { Is there any empirical evidence about the amount of } \\
\text { innovation that has occurred under prescriptive regimes } \\
\text { vs. PBC? }\end{array}$ \\
\hline bar & 7.06 & $\mathrm{mfr}$ & $\begin{array}{l}\text { Regulation typically does not } \\
\text { promote or discourage change. }\end{array}$ & $\begin{array}{l}\text { It is doubtful that there would be data on this. I am not } \\
\text { sure if the regulatory system encourages or } \\
\text { discourages innovation. Sometimes, you have to know } \\
\text { how to develop "around the code." Regulation may } \\
\text { pose a barrier to adoption, but not to innovation. } \\
\text { Sometimes, codes encourage innovation if the code } \\
\text { becomes more restrictive. Manufacturers then need to } \\
\text { innovate to satisfy those restrictions. Take carbon } \\
\text { monoxide detectors, smoke alarms, energy codes, etc. }\end{array}$ \\
\hline bar & 7.07 & reg & New York State, prior to most recent & New York is an example. The code was too \\
\hline
\end{tabular}

\footnotetext{
${ }^{8}$ Hahn, Robert and Scott Wallsten, "Whose Life is Worth More? (And Why Is It Horrible to Ask?)," Washington Post, June 1, 2003, pp B3.
} 


\begin{tabular}{|c|c|c|c|c|}
\hline 总 & 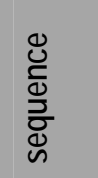 & 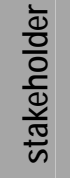 & 'flip chart' record & NIST notes \\
\hline & & & $\begin{array}{l}\text { re-write, was opposite of Las } \\
\text { Vegas-said 'no' too often. } \\
\text { Performance-based requirements } \\
\text { can encourage innovation through } \\
\text { offer of options (compliance options } \\
\text { in the case of New York State). }\end{array}$ & $\begin{array}{l}\text { prescriptive, and did not provide enough flexibility, and } \\
\text { led to higher costs to developers trying to get around } \\
\text { the regulations. Now, the provisions of the code } \\
\text { provide compliance options and are more successful. } \\
\text { Regulations cannot be created that cover everything. } \\
\text { Therefore, need a combination of prescriptive and } \\
\text { performance-based codes. }\end{array}$ \\
\hline att & 7.08 & mfr & $\begin{array}{l}\text { First paragraph of IRC gives } \\
\text { opportunity for flexibility in } \\
\text { performance compliance with the } \\
\text { code }\end{array}$ & $\begin{array}{l}\text { Chapter } 1 \text { of the code, titled "Alternative Methods," of } \\
\text { the Evaluation Service, is most encouraging of } \\
\text { innovation. Changes in code represent a dislocation of } \\
\text { the system, which spurs innovation. There is an } \\
\text { analogy in chemistry: need to scratch a surface in order } \\
\text { for crystals to form. }\end{array}$ \\
\hline bar & 7.09 & rch & $\begin{array}{l}\text { Industry is so fragmented, no single } \\
\text { organization is large enough to } \\
\text { overcome barriers to innovation. } \\
\text { Why is housing the only industry } \\
\text { that can not/ will not benefit from } \\
\text { innovation? } \\
\text { Until risk-based insurance is } \\
\text { available, innovation will not be } \\
\text { approved/adopted. } \\
\text { We need to link comprehensive } \\
\text { evaluation to a push for risk-based } \\
\text { insurance underwriting. }\end{array}$ & $\begin{array}{l}\text { One issue is the lack of market power of any builders in } \\
\text { the housing industry. In the long run, stimulating } \\
\text { development in housing is good, because it will benefit } \\
\text { society as a whole. But the housing industry is still not } \\
\text { totally geared in this direction. The home building } \\
\text { industry is more resistant to innovation than in other } \\
\text { industries. They perceive themselves in this way. } \\
\text { They do not buy it (innovation). Why can't the home } \\
\text { building industry be more like other industries in this } \\
\text { way? Why do they not reduce the barriers to } \\
\text { innovation? The ICC Evaluation Service did not } \\
\text { perform very well before. Using these evaluation } \\
\text { services, there needed to be an insurance program for } \\
\text { innovation to bridge the gap in reliability, uncertainty, } \\
\text { risk of system failure associated with new products. } \\
\text { The missing element is an insurance program for } \\
\text { innovation. In the current situation, local enforcers will } \\
\text { be held accountable for failure. With insurance, there } \\
\text { would be a cover for the homebuilder and component } \\
\text { manufacturer to encourage innovation and adoption. }\end{array}$ \\
\hline bar & 7.091 & $\mathrm{mfr}$ & (see notes) & $\begin{array}{l}\text { The evaluation services, as they stand today, do not } \\
\text { give any insurance. A third-party, if so inclined, may } \\
\text { want to take the results of an evaluation and then } \\
\text { proceed with some insurance against failure to protect } \\
\text { "early users" }\end{array}$ \\
\hline bar & 7.092 & rch & (see notes) & $\begin{array}{l}\text { You have to combine evaluations systems and } \\
\text { insurance in order to help increase development. }\end{array}$ \\
\hline bar & 7.10 & bld & $\begin{array}{l}\text { Want to reinforce notion of looking } \\
\text { at other industries for guidance: } \\
\text { there is a strong trend that } \\
\text { deregulation spurs innovation }\end{array}$ & $\begin{array}{l}\text { With homebuilding, can look at whether regulations } \\
\text { have an effect on innovation. There are many } \\
\text { regulated industries that became deregulated. Could } \\
\text { see whether a spurt of innovation followed the } \\
\text { deregulation. }\end{array}$ \\
\hline bar & 7.11 & rch & $\begin{array}{l}\text { Suggest that government undertake } \\
\text { research/modeling of insurance- } \\
\text { based approach to housing } \\
\text { innovation; determine appropriate } \\
\text { government roles (analogous to }\end{array}$ & $\begin{array}{l}\text { With the insurance idea, need to do the following. First, } \\
\text { do research and model what the insurance would look } \\
\text { like. Second, would the insurance industry be willing to } \\
\text { offer the product? And lastly, if the insurance industry } \\
\text { would not offer it, then who would? The government? }\end{array}$ \\
\hline
\end{tabular}




\begin{tabular}{|c|c|c|c|c|}
\hline 总 & 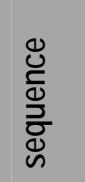 & 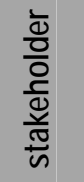 & 'flip chart' record & NIST notes \\
\hline & & & $\begin{array}{ll}\text { self-amortizing } & \text { mortgages); } \\
\text { determine feasibility. } & \end{array}$ & $\begin{array}{l}\text { An example is the FHA and self-amortizing insurance. } \\
\text { Would need to do feasibility studies. }\end{array}$ \\
\hline del & 7.12 & cst & $\begin{array}{l}\text { Look at entire regulatory system- } \\
\text { currently consists of prescriptive } \\
\text { frailty with alternative options. } \\
\text { (liability/technical issues go beyond } \\
\text { the capability of the field code } \\
\text { official) Frailty is the confidence that } \\
\text { prescriptive codes achieve desired } \\
\text { purposes/objectives. Tons of } \\
\text { innovation is just not used. Need to } \\
\text { better understand frailties and } \\
\text { impediments. }\end{array}$ & $\begin{array}{l}\text { The status quo is a prescriptive system with an } \\
\text { allowance for alternatives. Allowance has frailty } \\
\text { because it is subject to human acceptance. Any } \\
\text { solution would have to address this frailty. Examples of } \\
\text { solutions would be liability, education and technical } \\
\text { training, access to technical information. Another frailty } \\
\text { is whether the current prescriptive codes are on the } \\
\text { mark. With the hybrid, as one of the model code } \\
\text { developers discussed, there would still be liability and } \\
\text { education frailties. Another consideration is that many } \\
\text { innovations are not being used. They need selling and } \\
\text { marketing, but the performance side is harder to cover } \\
\text { liability. There would need to be understanding of the } \\
\text { components of the system. Lack of existing standards } \\
\text { can be a bigger barrier than regulations. }\end{array}$ \\
\hline met & 7.13 & $\mathrm{mcd}$ & $\begin{array}{l}\text { Want to clarify one aspect of } \\
\text { discussion, the role of Type } 1 \text { and } \\
\text { Type } 2 \text { statistical errors in } \\
\text { evaluating the effectiveness of } \\
\text { innovation. Need to look at both } \\
\text { sides of the issues-existence of } \\
\text { both 'good' and 'bad' innovation. }\end{array}$ & $\begin{array}{l}\text { Have to worry about both "Type 1" and "Type 2" } \\
\text { statistical errors with innovations. What about } \\
\text { innovations that are accepted but fail? These are the } \\
\text { types of concerns of code officials that have to be } \\
\text { addressed to get the changes in. }\end{array}$ \\
\hline att & 7.14 & bld & $\begin{array}{l}\text { Before you can define 'affordability', } \\
\text { you need to define 'safety' } \\
\text { ("acceptable risk"?). There is } \\
\text { currently no accepted credible } \\
\text { definition; nothing to push off from. } \\
\text { Local code officials do not know } \\
\text { what the code means in terms of } \\
\text { performance. Until decision-making } \\
\text { approval is removed, innovation will } \\
\text { not occur. }\end{array}$ & $\begin{array}{l}\text { Before you define affordability, must define the } \\
\text { standard for safety. Should it be "no injury or death"? } \\
\text { This is a barrier. There is no measure to bounce } \\
\text { affordability off of. Only the nuclear power industry has } \\
\text { specific criteria about safety. As with the energy code, } \\
\text { until there was a standard, it was not possible to assess } \\
\text { the relationship between affordability and energy } \\
\text { efficiency. The lack of credible standards makes it } \\
\text { impossible to enforce. Without a clear definition of } \\
\text { safety (and/or affordability, for instance) in the context } \\
\text { of a prescriptive set of code provisions, the introduction } \\
\text { and use of performance criteria may decrease. } \\
\text { Determining compliance with performance type } \\
\text { regulations can be more difficult and require additional } \\
\text { training for the code official. Also, many local officials } \\
\text { do not understand the codes they are trying to enforce. } \\
\text { They do not want to take a chance on a new product. }\end{array}$ \\
\hline bar & 7.15 & $\mathrm{mfr}$ & $\begin{array}{l}\text { We do code training as part of } \\
\text { product development process. }\end{array}$ & $\begin{array}{l}\text { There should be a continuing education and training } \\
\text { requirement for code officials. My company includes } \\
\text { training costs for code officials when it determines its } \\
\text { budget for developing a new product. It sees training } \\
\text { as part of the new product introduction process. }\end{array}$ \\
\hline bar & 7.16 & $\mathrm{mcd}$ & $\begin{array}{l}\text { We (ICC) do code official } \\
\text { certification training. }\end{array}$ & $\begin{array}{l}\text { Some states have certification and training for code } \\
\text { officials. But access and transportation are two issues. }\end{array}$ \\
\hline bar & 7.17 & rch & 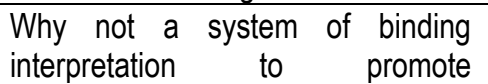 & (see record) \\
\hline
\end{tabular}




\begin{tabular}{|c|c|c|c|c|}
\hline 产 & 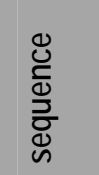 & 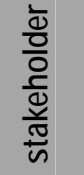 & 'flip chart' record & NIST notes \\
\hline & & & $\begin{array}{l}\text { consistency in code enforcement } \\
\text { (as used in some states with } \\
\text { statewide codes)? }\end{array}$ & \\
\hline bar & 7.18 & bld & $\begin{array}{l}\text { Only occurs through appeals } \\
\text { process-practitioners realize that } \\
\text { you cannot truly build to code. }\end{array}$ & $\begin{array}{l}\text { I have found that state-level code people in one } \\
\text { Midwest state are responsive if local officials are } \\
\text { resistant. In some other states, the only remedy if a } \\
\text { local code official disagrees or resists is the appeals } \\
\text { process. The truth is that strict adherence to the code } \\
\text { is impossible. }\end{array}$ \\
\hline bar & 7.19 & cst & That's a disappointing point of view. & That perspective is disappointing. \\
\hline att & 7.20 & mcd & $\begin{array}{l}\text { There are, in fact, mathematical } \\
\text { definitions for safety in the codes. }\end{array}$ & $\begin{array}{l}\text { Back to the absence of a definition of affordability: } \\
\text { There is no definition of affordability in the codes that } \\
\text { address it. This needs to be a mathematical formula. }\end{array}$ \\
\hline att & 7.21 & own & $\begin{array}{l}\text { We need to determine what is an } \\
\text { "acceptable level of risk" and then } \\
\text { protect against it-code officials are } \\
\text { not stakeholders, but do have an } \\
\text { interest (fear of responsibility for } \\
\text { building failure?) }\end{array}$ & $\begin{array}{l}\text { What constitutes acceptable risk? The building } \\
\text { community and the fire safety people do not agree on } \\
\text { this. The regulator is not a stakeholder in the financial } \\
\text { sense, but they do have something to lose with any } \\
\text { code that is not prescriptive because they may be held } \\
\text { accountable if they make a mistake. }\end{array}$ \\
\hline att & 7.211 & bld & (see notes) & $\begin{array}{l}\text { Must encourage use of the evaluation services for this. } \\
\text { The inspector should not have to make the decision. }\end{array}$ \\
\hline bar & 7.22 & cst & $\begin{array}{l}\text { 10-point ISO rating system looks } \\
\text { comprehensively at code } \\
\text { enforcement. Do they look at use of } \\
\text { NES reports? }\end{array}$ & $\begin{array}{l}\text { A participant earlier mentioned the 10-point ISO } \\
\text { certification rating system on the adoption, provision, } \\
\text { number of inspectors, training, of inspectors, of code. } \\
\text { Could build on this tool. With this rating, did they use } \\
\text { evaluation service reports (ESRs)? }\end{array}$ \\
\hline bar & 7.23 & cst & $\begin{array}{l}\text { Short answer is no, but do not put } \\
\text { all eggs in one basket-I accept } \\
\text { NES reports only if I agree; I rely on } \\
\text { multiple sources of information. }\end{array}$ & $\begin{array}{l}\text { No. They might, they might not. Evaluation reports are } \\
\text { not always accepted. I might not accept one that I do } \\
\text { not agree with, because evaluation is also subject to } \\
\text { human error. I am as receptive toward products with } \\
\text { ESRs as I am toward those without them. The lack of a } \\
\text { report should not always be viewed as a barrier to } \\
\text { acceptance. }\end{array}$ \\
\hline bar & 7.24 & $\mathrm{mfr}$ & $\begin{array}{l}\text { Never had an NES report turned } \\
\text { down, but it takes work. }\end{array}$ & $\begin{array}{l}\text { I have never had an ESR denied by a code official. } \\
\text { Some have required them. Others have accepted the } \\
\text { data submitted to the evaluation services if an ESR is } \\
\text { pending. }\end{array}$ \\
\hline bar & 7.25 & bld & $\begin{array}{l}\text { Some code officials do not even use } \\
\text { code language, much less NES } \\
\text { reports in making decisions. }\end{array}$ & $\begin{array}{l}\text { Some code officials disagree with the code and will not } \\
\text { adhere. }\end{array}$ \\
\hline bar & 7.251 & bld & (see notes) & Schenectady is one example. \\
\hline bar & 7.252 & rch & (see notes) & Dallas is another. \\
\hline bar & 7.26 & bld & $\begin{array}{l}\text { Reports are limited only to existing } \\
\text { code requirements and do not test } \\
\text { against purposes of innovation } \\
\text { (whatever those may be, such as } \\
\text { durability); do not rely only on } \\
\text { reports. }\end{array}$ & $\begin{array}{l}\text { There are limits to ESRs. They do not address } \\
\text { durability or affordability. The evaluations are only for } \\
\text { the adherence to the codes that are existing. The } \\
\text { code/evaluation process calls for extraneous testing } \\
\text { that is not appropriate for the material in many cases. }\end{array}$ \\
\hline pro & 7.27 & $\mathrm{mfr}$ & $\begin{array}{l}\text { Product must be equivalent to } \\
\text { alternative materials. }\end{array}$ & $\begin{array}{l}\text { In the "alternative methods" clause, durability is } \\
\text { included. }\end{array}$ \\
\hline
\end{tabular}




\begin{tabular}{|c|c|c|c|c|}
\hline 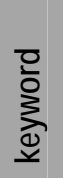 & 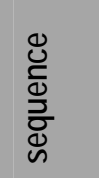 & 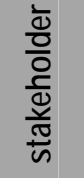 & 'flip chart' record & NIST notes \\
\hline bar & 7.28 & bld & $\begin{array}{l}\text { Some AHJs require engineering } \\
\text { certification for each installation-a } \\
\text { very expensive burden. }\end{array}$ & $\begin{array}{l}\text { For some officials, if you get the engineer's seal on the } \\
\text { design, then you can use it. But this is costly. So this } \\
\text { is still a barrier to adoption of new technology. }\end{array}$ \\
\hline bar & 7.29 & cst & $\begin{array}{l}\text { Barriers at local level may be } \\
\text { politically based. }\end{array}$ & $\begin{array}{l}\text { Officials want to offload risk; they do not want the } \\
\text { liability. For example, EIFS. You could get a political } \\
\text { barrier. Maybe a union will not let a code change in, } \\
\text { and they are told not to improve it or will fight to keep } \\
\text { new technology out when code changes are proposed. } \\
\text { Even in spite of scientific justification for a component's } \\
\text { use, there may be politically motivated resistance. An } \\
\text { example is steel framing and the influence of California } \\
\text { unions on local officials. Political issues may similarly } \\
\text { arise with respect to code language and interpretations } \\
\text { of the code. }\end{array}$ \\
\hline bar & 7.30 & bld & $\begin{array}{l}\text { Risk insurance coverage (for } \\
\text { manufacturer, builder, or owner) } \\
\text { could overcome many of these } \\
\text { problems. }\end{array}$ & (see record) \\
\hline bar & 7.31 & mcd & $\begin{array}{l}\text { Higher level issue is involved here- } \\
\text { what should regulators do differently } \\
\text { than they do now? Regulators are } \\
\text { there to provide a function-that } \\
\text { function must be acceptable to } \\
\text { those being regulated in order for } \\
\text { the system to work effectively. }\end{array}$ & $\begin{array}{l}\text { Can the regulatory system be used to encourage } \\
\text { innovation? What can be done differently? Regulators } \\
\text { have a specific function. If manufacturers do not think } \\
\text { the goals are legitimate and do not respect the } \\
\text { regulators' intellectual capability, then they will not get } \\
\text { far in improving the system. }\end{array}$ \\
\hline bar & 7.311 & rch & (see notes) & $\begin{array}{l}\text { Is there research showing resistance of local building } \\
\text { code officials to innovation? }\end{array}$ \\
\hline bar & 7.312 & mcd & (see notes) & $\begin{array}{l}\text { Also, some builders resist innovation. Each actor has } \\
\text { reasons to resist innovation. }\end{array}$ \\
\hline bar & 7.32 & $\mathrm{mfr}$ & $\begin{array}{lll}\text { What can be positively said to } \\
\text { encourage } \\
\text { innovation? }\end{array}$ & $\begin{array}{l}\text { How do you change the outlook of code officials to } \\
\text { encourage more interest in acceptance of housing } \\
\text { innovation? }\end{array}$ \\
\hline bar & 7.33 & own & $\begin{array}{l}\text { The ICC and New Jersey } \\
\text { Rehabilitation Codes are steps in } \\
\text { the right direction. }\end{array}$ & $\begin{array}{l}\text { The ICC and the New Jersey Rehabilitation Code are } \\
\text { good examples. They are steps in the right direction. } \\
\text { There is a need for regulations. }\end{array}$ \\
\hline bar & 7.34 & own & $\begin{array}{l}\text { Going to statewide code increases } \\
\text { consistency in enforcement. }\end{array}$ & $\begin{array}{l}\text { If there were a move to state-wide codes, there would } \\
\text { be better enforcement. }\end{array}$ \\
\hline bar & 7.341 & own & (see notes) & And predictability. \\
\hline bar & 7.35 & reg & $\begin{array}{l}\text { Local officials need assurance-NY } \\
\text { can issue binding interpretations, } \\
\text { although not often done: it is a } \\
\text { useful tool. }\end{array}$ & $\begin{array}{l}\text { Local building officials need some certainty, for } \\
\text { someone else to be accountable, that individual } \\
\text { interpretation will not provide. They don't want the } \\
\text { decision to come back and bite them. One solution is } \\
\text { for the government to issue a binding interpretation to } \\
\text { take the interpretation out of the building officials' } \\
\text { hands. }\end{array}$ \\
\hline pro & 7.36 & mcd & $\begin{array}{l}\text { States should be careful of taking on } \\
\text { product certification functions (see } \\
\text { Florida example); it could increase } \\
\text { complexity, uncertainty, and cost. }\end{array}$ & $\begin{array}{l}\text { Need to be careful with product approval and } \\
\text { conformity. There is a difference between uniformity in } \\
\text { interpretation (such as in Virginia) and conformity in } \\
\text { assessment (Florida). The latter leads to creation of a } \\
\text { new bureaucracy and another check and balance. }\end{array}$ \\
\hline
\end{tabular}




\begin{tabular}{|c|c|c|c|c|}
\hline 잏 & 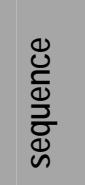 & 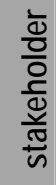 & 'flip chart' record & NIST notes \\
\hline & & & & There are already enough checks and balances. \\
\hline pro & 7.37 & cst & $\begin{array}{l}\text { Certification needs to recognize } \\
\text { contractual trade influences and } \\
\text { impacts. }\end{array}$ & (see record) \\
\hline
\end{tabular}

Discussion session \#8: Who should bear the costs of development of new delivery systems and new infrastructure systems that are needed for innovation to penetrate the market at the scale of the entire house and its delivery system?

\begin{tabular}{|c|c|c|c|c|}
\hline 产 & 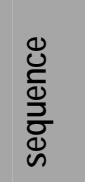 & $\begin{array}{l}\frac{\text { dँ }}{0} \\
\frac{0}{0} \\
\frac{\bar{d}}{\omega} \\
\frac{\pi}{\omega}\end{array}$ & 'flip chart' record & NIST notes \\
\hline del & 8.01 & bld & $\begin{array}{l}\text { Mandated innovation is } \\
\text { disproportionately a burden to low- } \\
\text { income buyers of housing. } \\
\text { Owners are interested in restricting } \\
\text { supply to protect the value of their } \\
\text { assets. } \\
\text { Politicians have an interest in } \\
\text { protecting asset value as well. } \\
\text { Should builders bear some of the } \\
\text { cost, especially for innovations that } \\
\text { the buyer is not expressly interested } \\
\text { in? } \\
\text { Concentration in the building } \\
\text { industry (SF) is already occurring; } \\
\text { do we want it to accelerate? Would } \\
\text { that promote innovation (in a less } \\
\text { competitive marketplace)? Medium- } \\
\text { sized builders are a key segment of } \\
\text { homebuilders. } \\
\text { If considering a new delivery } \\
\text { system, how would it be regulated? } \\
\text { Would local regulators necessarily } \\
\text { lose control of the process? }\end{array}$ & $\begin{array}{l}\text { - To an extent this is obvious: the manufacturer will } \\
\text { - } \quad \text { It is easy paying for innovations. } \\
\text { buyer. } \\
\text { - People that own existing homes are possible } \\
\text { bearers of cost: it is in their interest to restrict the } \\
\text { supply in order to increase house value. } \\
\text { - Homebuilders are in a position to pass on to } \\
\text { consumer, except if consumers show no interest in } \\
\text { the specific innovation. } \\
\text { - If we have a market with fewer large innovators, } \\
\text { do more costs get passed on to the consumer? } \\
\text { - Is there a viable place for the medium sized } \\
\text { - producer? } \\
\text { New delivery system: do local officials lose control } \\
\text { of the system? }\end{array}$ \\
\hline del & 8.02 & $\mathrm{mfr}$ & $\begin{array}{l}\text { Development costs will get passed } \\
\text { to the consumer, and, even so, will } \\
\text { not be undertaken if too high. } \\
\text { If builders cannot pass on at least } \\
\text { part of the costs, they will not buy. } \\
\text { Question is not who pays, but how } \\
\text { costs are distributed. }\end{array}$ & $\begin{array}{l}\text { - Materials manufacturer will pass on increased } \\
\text { costs to the consumer. } \\
\text { - If a builder cannot pass on direct costs, they will } \\
\text { stop the innovation. } \\
\text { - Everyone along the line is going to pay some } \\
\text { share for the innovation, the question is: How is } \\
\text { the total cost divided among the different groups? } \\
\text { - Initial cost is going to be borne by the initial } \\
\text { innovator. }\end{array}$ \\
\hline del & 8.03 & cst & $\begin{array}{l}\text { We are asked to look at these } \\
\text { issues at material/component scale } \\
\text { and at product delivery scale. }\end{array}$ & $\begin{array}{l}\text { It was proposed that we look at technology at two } \\
\text { scales, the components/materials scale and the whole } \\
\text { house and delivery system scale. }\end{array}$ \\
\hline
\end{tabular}




\begin{tabular}{|c|c|c|c|c|}
\hline 产 & 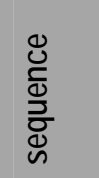 & 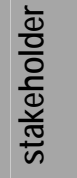 & 'flip chart' record & NIST notes \\
\hline bar & 8.031 & $\mathrm{mcd}$ & (see notes) & $\begin{array}{l}\text { The builder has trouble developing/justifying the use of } \\
\text { innovative resources because they will benefit all of } \\
\text { society, but they may not see all of their initial } \\
\text { investment coming back. }\end{array}$ \\
\hline del & 8.04 & mfr & $\begin{array}{l}\text { Builder will pay the costs of the new } \\
\text { delivery process at the outset, but } \\
\text { will pass along as soon as possible. }\end{array}$ & No one entity will bear the costs of innovation. \\
\hline del & 8.05 & own & $\begin{array}{l}\text { This is what operation breakthrough } \\
\text { was supposed to do in the early } \\
70 \text { s. }\end{array}$ & $\begin{array}{l}\text { One example is the systems analysts at HUD with } \\
\text { Operation Breakthrough, where the government bore } \\
\text { some of the costs of innovation. }\end{array}$ \\
\hline del & 8.06 & rch & $\begin{array}{l}\text { Government has moved away from } \\
\text { any consideration of 'command and } \\
\text { control' strategies; public benefits of } \\
\text { improved housing have been } \\
\text { dismissed; tax breaks and R\&D } \\
\text { have been eliminated. }\end{array}$ & $\begin{array}{l}\text { Except for the command and control nature of } \\
\text { Operation Breakthrough, this is a good example. } \\
\text { Where is the government part in these costs? There } \\
\text { are many public benefits to society of some of these } \\
\text { development costs. For example, NIH and } \\
\text { pharmaceuticals. This is now inadequate. Need tax } \\
\text { subsidies, research and development, risk coverage } \\
\text { (coinsurance), education, and marketing. As was } \\
\text { previously mentioned, } 30 \text { years ago, BFRL was a major } \\
\text { source of basic research. }\end{array}$ \\
\hline del & 8.07 & cst & $\begin{array}{l}\text { Should a change in the form of } \\
\text { ownership be considered? }\end{array}$ & $\begin{array}{l}\text { FHA mortgage insurance in the U.S. in the 1930s } \\
\text { through 1950s created the current housing delivery } \\
\text { system. Participants have given other examples of } \\
\text { innovations in the housing delivery system. One } \\
\text { possibility would be to change the form of } \\
\text { homeownership. }\end{array}$ \\
\hline del & 8.071 & rch & (see notes) & $\begin{array}{l}\text { This would never happen. Encouraging home } \\
\text { ownership has been the policy of every administration. }\end{array}$ \\
\hline del & 8.072 & cst & (see notes) & $\begin{array}{l}\text { If housing were a service rather than property, then it } \\
\text { could be different. }\end{array}$ \\
\hline del & 8.08 & mcd & $\begin{array}{l}\text { Vertical integration, engineered } \\
\text { systems, modular integration are } \\
\text { strongest approaches; trades and } \\
\text { agencies should get together and } \\
\text { decide on a course of action. }\end{array}$ & $\begin{array}{l}\text { Based on the reading of the question, need to move } \\
\text { toward vertical integration, engineered solutions as a } \\
\text { participant earlier suggested. NIST and HUD need to } \\
\text { define some concepts to bring new methods of delivery, } \\
\text { such as vertical integration and modularization. The } \\
\text { builder has trouble developing/justifying the use of } \\
\text { innovative resources because they will benefit all of } \\
\text { society, but they may not see all of their initial } \\
\text { investment coming back. }\end{array}$ \\
\hline del & 8.09 & bld & $\begin{array}{l}\text { Question of who pays remains; what } \\
\text { of the suggested changes would be } \\
\text { paid by actors? By feds? }\end{array}$ & $\begin{array}{l}\text { This goes to externalities. To internalize these, need } \\
\text { the Federal government. The Federal government is } \\
\text { the appropriate bearer for the cost of such innovations } \\
\text { that increase the general social welfare. Education and } \\
\text { training address a different market failure. }\end{array}$ \\
\hline del & 8.091 & rch & (see notes) & $\begin{array}{l}\text { What about labeling, such as Energy Star? New York } \\
\text { State has done more on this than any other state, to } \\
\text { decrease energy consumption. The construction } \\
\text { industry wants to publicize these risks and expenses } \\
\text { (i.e., have these risks and expenses borne by the } \\
\text { public). }\end{array}$ \\
\hline
\end{tabular}




\begin{tabular}{|c|c|c|c|c|}
\hline 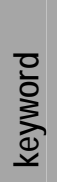 & 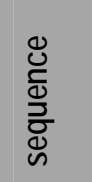 & 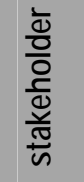 & 'flip chart' record & NIST notes \\
\hline del & 8.092 & $\mathrm{mfr}$ & (see notes) & $\begin{array}{l}\text { The construction industry does not devote as much } \\
\text { resources to R\&D. }\end{array}$ \\
\hline del & 8.093 & rch & (see notes) & It does not look for public help, either. \\
\hline del & 8.094 & $\mathrm{mfr}$ & (see notes) & $\begin{array}{l}\text { Everyone will see the benefits of increased home } \\
\text { ownership over time, but taxpayers will be the group } \\
\text { paying the price. }\end{array}$ \\
\hline del & 8.10 & rch & $\begin{array}{l}\text { Substantial public investment is not } \\
\text { a consideration. }\end{array}$ & (see record) \\
\hline per & 8.11 & bld & $\begin{array}{l}\text { Current federal policy asserts that } \\
\text { "ownership improves housing". }\end{array}$ & $\begin{array}{l}\text { The benefit of home ownership is the long-run stake in } \\
\text { the asset. }\end{array}$ \\
\hline pro & 8.12 & rch & $\begin{array}{l}\text { Have not heard 'pilot project' as an } \\
\text { approach (analogy to medical } \\
\text { industry); allows not total change, } \\
\text { but immediate test of change. }\end{array}$ & $\begin{array}{l}\text { What about pilot projects with interface between private } \\
\text { and public/government entities? Should not be all or } \\
\text { nothing. Deep-pocketed publicly owned companies } \\
\text { have to be the first movers of new innovations, with } \\
\text { some help from government. }\end{array}$ \\
\hline pro & 8.121 & rch & (see notes) & Only peanuts go into these projects. \\
\hline pro & 8.122 & rch & (see notes) & $\begin{array}{l}\text { Even if small scale, it may be helpful for a specific area, } \\
\text { such as flood plains in lowa. }\end{array}$ \\
\hline pro & 8.123 & mcd & (see notes) & Acorns, to grow into trees. \\
\hline pro & 8.13 & rch & $\begin{array}{l}\text { 'Pilot project' may not work well } \\
\text { because of conflict with existing } \\
\text { infrastructure; change may be } \\
\text { viewed as negative-if the pilot is } \\
\text { big, it may be blocked by existing } \\
\text { industry and consumer afraid of } \\
\text { reduced asset value. }\end{array}$ & $\begin{array}{l}\text { There must be a limited role for government. There are } \\
\text { parties who will be losers with these changes. If you } \\
\text { cut the cost by } 30 \% \text {, that is fundamentally disruptive to } \\
\text { the market price for homes. }\end{array}$ \\
\hline pro & 8.131 & own & (see notes) & $\begin{array}{l}\text { Existing communities would prevent the lower-cost } \\
\text { housing from being built in the neighborhood. It would } \\
\text { be too disruptive }\end{array}$ \\
\hline pro & 8.132 & rch & (see notes) & $\begin{array}{l}\text { The first mover probably would price without cutting by } \\
30 \% \text { and would capture economic rents. It will be } \\
\text { deep pocket publicly held companies doing this. }\end{array}$ \\
\hline del & 8.14 & cst & $\begin{array}{l}\text { Could be the subject of study-is } \\
\text { there a role for government in a test } \\
\text { of changing housing delivery? }\end{array}$ & $\begin{array}{l}\text { There was a NSF project funded by Alcoa, Gulf, and } \\
\text { Westinghouse (General Electric), which followed } \\
\text { Operation Breakthrough to ask whether there was a } \\
\text { role for these types of companies in housing delivery. } \\
\text { The answer they arrived at was, probably not. Now, } \\
\text { Fannie and Freddie have come, the National Evaluation } \\
\text { Service and others have developed. Given these } \\
\text { changes, is there a role now? In today's market, is } \\
\text { there a role for major home producers? }\end{array}$ \\
\hline bar & 8.15 & $\mathrm{mcd}$ & $\begin{array}{l}\text { Why did } 40 \text { s innovation occur? It did } \\
\text { not threaten existing stockowners; } \\
\text { more optimistic about buyer/ } \\
\text { customer reaction to change. }\end{array}$ & $\begin{array}{l}\text { After World War II, there was a huge growth of } \\
\text { affordable housing. Why was there no objection then? } \\
\text { The reasons are: they were built in other areas, there } \\
\text { was great need, and they were not seen as } 30 \% \\
\text { cheaper because of the balance between cost and } \\
\text { attribute was not challenged. Why could this not } \\
\text { happen again? }\end{array}$ \\
\hline bar & 8.16 & bld & $\begin{array}{l}\text { There was less regulation (in the } \\
40 \text { s). }\end{array}$ & $\begin{array}{l}\text { The combination of affordability and other } \\
\text { characteristics provides a historical precedent from the }\end{array}$ \\
\hline
\end{tabular}




\begin{tabular}{|c|c|c|c|c|}
\hline 产 & 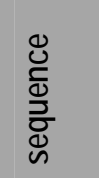 & 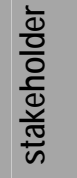 & 'flip chart' record & NIST notes \\
\hline & & & & period immediately following World War II. \\
\hline bar & 8.17 & bld & $\begin{array}{l}\text { Current attitudes toward resisting } \\
\text { change are relatively rigid. }\end{array}$ & $\begin{array}{l}\text { Also, to add another perspective, this construction } \\
\text { happened after the Great Depression, which saw } \\
\text { widespread price deflation. Therefore, cheaper homes } \\
\text { were not seen as a threat. }\end{array}$ \\
\hline bar & 8.171 & mcd & (see notes) & $\begin{array}{l}\text { There is some precedent in how large-scale } \\
\text { innovations in product and delivery were adopted. }\end{array}$ \\
\hline bar & 8.172 & bld & (see notes) & $\begin{array}{l}\text { Now, homeowners' associations object to changes (on } \\
\text { the basis of change to the character of the community). } \\
\text { Post-World War II history was unusual. }\end{array}$ \\
\hline bar & 8.173 & rch & (see notes) & $\begin{array}{l}\text { Also, at that time, they were building for everyone, the } \\
\text { mass market. Now, the builders are building for the } \\
\text { high end of the market, not mass market. }\end{array}$ \\
\hline bar & 8.174 & rch & (see notes) & Because there is an existing housing stock. \\
\hline bar & 8.175 & mcd & (see notes) & $\begin{array}{l}\text { The closer we move to a situation in which the kids } \\
\text { can't afford a home, the closer you move to the time } \\
\text { when this situation becomes intolerable. }\end{array}$ \\
\hline del & 8.18 & mfr & $\begin{array}{l}\text { Perhaps we should focus on } \\
\text { changing delivery of existing stock } \\
\text { rehabilitation. }\end{array}$ & $\begin{array}{l}\text { What will the nature of the new delivery system be? } \\
\text { Will the existing suburbs of the } 1950 \text { s be rehabilitated? } \\
\text { Will this be the new delivery system? For many people, } \\
\text { their first home is an old suburban home. Or will it be } \\
\text { an entirely new delivery system? }\end{array}$ \\
\hline del & 8.19 & bld & $\begin{array}{l}\text { No individual will put up with any } \\
\text { cost to change product delivery. } \\
\text { Who will pay? A demo project could } \\
\text { prove concept. Entrepreneur will } \\
\text { then move to rental side because } \\
\text { lender will not incent builder directly. } \\
\text { ROI could be changed by } 5 \% \text { by } \\
\text { assuming risk of utility/energy costs. }\end{array}$ & $\begin{array}{l}\text { Relying on rehabilitated housing would take too much } \\
\text { time. Areas like Johnstown and Schenectady, NY were } \\
\text { built during the 1920s and 1930s. There is now a lot of } \\
\text { vacancy there. The problem with these areas is that } \\
\text { they are past desirability, and that is a barrier to } \\
\text { rehabilitation. Regarding an earlier comment about the } \\
\text { cost of infrastructure, I am now demonstrating and } \\
\text { developing a project using renewable energy. Some } \\
\text { people can find ways of capturing economic rents. I } \\
\text { make an } 18 \% \text { return on investment (ROI), five } \\
\text { percentage points higher than I would have, by } \\
\text { capturing the savings. Some people do not even make } \\
\text { five percent ROI. }\end{array}$ \\
\hline seg & 8.20 & mcd & $\begin{array}{l}\text { Imagine easy ways to change how } \\
\text { you use your house. Need a } \\
\text { delivery system to routinize rehab } \\
\text { and reuse. Introduce innovation } \\
\text { through rehab rather than new } \\
\text { construction. }\end{array}$ & $\begin{array}{l}\text { Back to the earlier comment about rehabilitation as an } \\
\text { alternative delivery system: Could you make renovated } \\
\text { houses a place to implement innovations? Now, there } \\
\text { is a rash of people in my neighborhood adding rooms } \\
\text { or second stories. If this were easier to do, what would } \\
\text { happen? How about rehabilitation and expanded } \\
\text { capacity as an innovative system of delivery? }\end{array}$ \\
\hline seg & 8.21 & rch & $\begin{array}{l}\text { Suburban } 1 \text { st home means "lawns } \\
\text { and commutes"- -should we focus } \\
\text { on a different } 1 \text { st home model? }\end{array}$ & $\begin{array}{l}\text { One must consider the current housing market. The } \\
\text { problem is the need to match preferences over the first } \\
\text { home with what is available. My first home was in the } \\
\text { suburbs. It did not match my preferences. There was } \\
\text { a yard that I did not want to have to maintain. I had a } \\
\text { long commute. Need to address the demographic of } \\
\text { first-time homebuyers that do not want lawn } \\
\text { maintenance and long commutes. How about }\end{array}$ \\
\hline
\end{tabular}




\begin{tabular}{|c|c|c|c|c|}
\hline 总 & 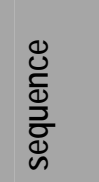 & 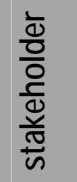 & 'flip chart' record & NIST notes \\
\hline & & & & rehabilitating loft apartments in the urban core? \\
\hline seg & 8.22 & bld & $\begin{array}{l}\text { We see indications of marketplace } \\
\text { changes, but cannot yet confirm. }\end{array}$ & \\
\hline seg & 8.221 & $\mathrm{mfr}$ & (see notes) & $\begin{array}{l}\text { The community where I live is on the edge of the urban } \\
\text { core, about } 5 \text { min to downtown. It is an area where } \\
\text { there are many first-time homebuyers. }\end{array}$ \\
\hline seg & 8.23 & rch & $\begin{array}{l}\text { Reconfigure low-density } \\
\text { neighborhoods to high density. }\end{array}$ & $\begin{array}{l}\text { Hope } 6 \text { is an example, but it is already on publicly } \\
\text { owned property. }\end{array}$ \\
\hline seg & 8.24 & rch & $\begin{array}{l}\text { Most new homes will be sprawl and } \\
\text { SF on periphery of urban areas; } \\
\text { clearly need is for innovation in } \\
\text { existing housing stock, but most } \\
\text { new products will be for new } \\
\text { construction. } 50 \text { million new buyers } \\
\text { over next } 50 \text { years will push new } \\
\text { development even though they may } \\
\text { enter market through purchase of } \\
\text { existing stock. }\end{array}$ & $\begin{array}{l}\text { For most, the sprawl and new construction will } \\
\text { continue. People want new construction. In the next } \\
25 \text { years, existing housing will go primarily to } \\
\text { immigrants, so there will a number of new housing } \\
\text { starts. }\end{array}$ \\
\hline seg & 8.241 & mfr & (see notes) & $\begin{array}{l}\text { The reason I hear people want to do this is for new } \\
\text { schools. The schools in my area are not good. }\end{array}$ \\
\hline seg & 8.242 & rch & (see notes) & $\begin{array}{l}\text { There is a lack of technology directed at the existing } \\
\text { housing stock. Most of the products are targeted to } \\
\text { new homes. This will affect who pays and bears the } \\
\text { costs of new product development. }\end{array}$ \\
\hline bar & 8.25 & bld & $\begin{array}{l}\text { In-fill development runs into } \\
\text { titling/subdivision problems; do not } \\
\text { understand suggested spur to } \\
\text { innovation. }\end{array}$ & $\begin{array}{l}\text { The choice is between new homes or rehabbing old } \\
\text { homes. Infill development is made difficult by land use } \\
\text { requirements. Regarding a previous comment, I am } \\
\text { not sure how rehabilitation is connected to the } \\
\text { introduction of new technologies). }\end{array}$ \\
\hline bar & 8.26 & mcd & $\begin{array}{l}\text { Intent is to make rehab much more } \\
\text { frequent (spurring innovation) and } \\
\text { make delivery easier. }\end{array}$ & $\begin{array}{l}\text { The concern is how it would happen. It was just an } \\
\text { unconventional idea. An important concern is to make } \\
\text { renovations easily available to the housing public. }\end{array}$ \\
\hline del & 8.27 & own & $\begin{array}{l}\text { See opportunity to do local pilot } \\
\text { projects. }\end{array}$ & $\begin{array}{l}\text { The systems for acceptance of new developments lie } \\
\text { with the local government. There is good potential for } \\
\text { local government to get involved in this new delivery } \\
\text { system. For example, San Diego, CA spent resources } \\
\text { to streamline the regulatory system. Montgomery } \\
\text { County, MD is also doing this. These are big budget } \\
\text { jurisdictions that can afford to do this. }\end{array}$ \\
\hline bar & 8.28 & cst & $\begin{array}{l}\text { Planned development approaches } \\
\text { allow flexibility in zoning. Is it time } \\
\text { now to plan for future use by adding } \\
\text { flexibility to be adaptable to and } \\
\text { facilitate future rehab. } \\
\text { Resistance to modular housing at } \\
\text { local level cannot be explained by } \\
\text { differences over time. }\end{array}$ & $\begin{array}{l}\text { Must look at the role of zoning, density, and cost. In a } \\
\text { new market, see planned residential/housing } \\
\text { developments (PRD/PHD). Are these viable and } \\
\text { durable, or will they decay and people will move? Also, } \\
\text { can we plan for } 30 \text { years to } 40 \text { years from now by } \\
\text { reorienting the layout of a home? Systems-wide } \\
\text { engineering could be used to facilitate future rehab. } \\
\text { For example, to be able to move a load-bearing wall to } \\
\text { change the floor plan to satisfy future tastes, needs, } \\
\text { and preferences. Use more partitions. Make the } \\
\text { kitchen a module that can be plugged in or unplugged }\end{array}$ \\
\hline
\end{tabular}




\begin{tabular}{|c|c|c|c|c|}
\hline 胥 & 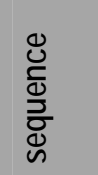 & 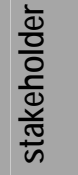 & 'flip chart' record & NIST notes \\
\hline & & & & and moved. \\
\hline pro & 8.29 & bld & $\begin{array}{l}\text { Market is responding by seeking } \\
\text { opportunities for future change (e.g. } \\
\text { blocking for grab rails in baths). }\end{array}$ & $\begin{array}{l}\text { Is it possible to look forward to rehabbing current } \\
\text { housing in approximately } 20 \text { years? Would a viable } \\
\text { new delivery system be movable walls and developing } \\
\text { housing today with "exchangeable" rooms? The market } \\
\text { is addressing the question of flexibility, but not on that } \\
\text { scale. Some of the things being done now are to, } \\
\text { instead of installing grab bars in the tub ahead of time, } \\
\text { putting blocking in the wall so that they can receive } \\
\text { bars when they do become needed when the } \\
\text { homeowner gets older. }\end{array}$ \\
\hline att & 8.30 & rch & $\begin{array}{l}\text { Flexibility related to addressing } \\
\text { sprawl may be effective. }\end{array}$ & $\begin{array}{l}\text { This flexibility is found in commercial office space. } \\
\text { NIST North is leased, is it not? Commercial space } \\
\text { must be flexible because the tenants change and so do } \\
\text { their needs. To go back to the zoning and local } \\
\text { regulation issues, my organization sees sprawl as a } \\
\text { pejorative. The example of Montgomery County, MD's } \\
\text { budget is unusual, and it will tighten. Everywhere, local } \\
\text { budgets are tight, and this has to be dealt with. If local } \\
\text { governments do not get involved, urban sprawl will } \\
\text { eventually force them to do so. }\end{array}$ \\
\hline bar & 8.301 & bld & (see notes) & $\begin{array}{l}\text { There is little interest in having land available for more } \\
\text { new housing at this time: in } \mathrm{NJ}, 63 \% \text { of the public } \\
\text { voted to restrict } 50 \% \text { of orphan land then designated } \\
\text { for housing development out of use. They voted } \\
\text { against new housing. The yearly charge/cost of a } \\
\text { house is base on: } \\
\text { - Inventory value } \\
\text { - Maintenance costs } \\
\text { - Operating costs } \\
\text { - Durability (currently no rating scale/little data) } \\
\text { Durability and maintenance values are closely related. }\end{array}$ \\
\hline bar & 8.31 & mcd & $\begin{array}{l}\text { People want things for reasons that } \\
\text { are in inherent conflict. }\end{array}$ & $\begin{array}{l}\text { The vote may have been motivated by different things. } \\
\text { They did not necessarily want less housing. }\end{array}$ \\
\hline bar & 8.32 & rch & (see notes) & It's orphan land. People don't want a long commute. \\
\hline bar & 8.33 & cst & (see notes) & $\begin{array}{l}\text { Regarding the acceptance or resistance to modules, } \\
\text { the resistance is based on historical experience } \\
\text { because there may be different or reduced standards in } \\
\text { one house compared to the house next door. } \\
\text { Modularization would lead to loss of local control. }\end{array}$ \\
\hline bar & 8.34 & bld & (see notes) & $\begin{array}{l}\text { California addressed this question in } 1980 \text { by allowing } \\
\text { manufactured units in existing areas as long as the look } \\
\text { and character of the area was preserved. }\end{array}$ \\
\hline bar & 8.35 & cst & (see notes) & Was it a hard or easy swallow for local officials? \\
\hline bar & 8.36 & bld & (see notes) & There was a cost. \\
\hline
\end{tabular}




\section{Appendix B Individual Comments Organized by Stakeholder Group and Keyword}

Appendix B consists of comments first sorted by stakeholder group affiliations and then by keyword topics. The resulting tables present, in columns from left to right, the discussion session topic in which the statement was made, the sequential identification of the comment, the 'flip chart' record of the discussion, and a synthesis of notes taken by NIST participants.

Discussion Session Topics: Eight question-based topics were posed to the group for discussion in separate hour-long sessions.

- \#1: Who benefits from the housing innovation, both at component scale and at the scale of the entire house and its delivery system? [ben]

- \#2: How to "push" innovation benefits to the homeowner, at the scale of housing components? [push]

- \#3: How does each stakeholder view and compute life-cycle costs and benefits compared to first costs, at both scales? [comp]

- \#4: How does each stakeholder view and compute future benefits that are uncertain or contingent on very low probability events, such as protection from earthquakes or hurricanes that may never happen, at both scales? [cert]

- \#5: How should the uncertainty and risk associated with using new versus traditional technology be addressed, at both scales? [risk]

- \#6: How should society value or monetize the social costs and benefits of introducing technology in residential housing, such as energy conservation or disaster relief and recovery, at both scales? [soc]

- \#7: Can the regulatory system be used to encourage innovation, and to distinguish innovations with net benefits from those with net costs, at both component scale and at the scale of the entire house and its delivery system? [reg]

- \#8: Who should bear the costs of development of new delivery systems and new infrastructure systems that are needed for innovation to penetrate the market at the scale of the entire house and its delivery system? [cost]

The material presented in this appendix is designed to provide a comprehensive compilation of each stakeholder group's perspectives on housing affordability-related issues. By focusing on a single stakeholder group's perspectives, representatives of each of the key stakeholder groups (e.g., readers and workshop attendees) gain insights that will be useful in identifying areas of consensus that will facilitate the production of a set of affordability guidelines for owner-occupied housing. This approach does, however, place a slight additional burden on the reader. The richness of the discussions and dynamic nature of the comments over the course of the two-day workshop often meant that a given stakeholder group (e.g., owner) was responding to a comment by a different stakeholder group (e.g., lender). Thus, the context of the original comment may sometimes be unclear. The authors have addressed this issue through the use of sequence numbers. Because each comment has a unique sequence number, if the reader wishes clarification on the context or implied meaning of a specific comment, they can refer to Appendix A, find the sequence number of the comment of interest, and trace the 
evolution of the discussion leading up to that comment.

\section{Owners}

- Attribute: affordability, durability, safety, etc. (flexibility, substitutability, customizability)

\begin{tabular}{|c|c|c|c|}
\hline 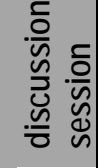 & 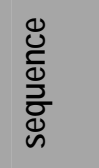 & 'flip chart' record & NIST notes \\
\hline ben & 1.34 & $\begin{array}{l}\text { Innovation is an invention that } \\
\text { succeeds in the marketplace; no } \\
\text { success-no innovation }\end{array}$ & $\begin{array}{l}\text { The definition of innovation is an invention that } \\
\text { succeeds in the marketplace. What ensures its } \\
\text { success? Innovation will only occur if people perceive } \\
\text { a priori benefit. }\end{array}$ \\
\hline ben & 1.43 & $\begin{array}{l}\text { Community concerns should be } \\
\text { considered; they may be the } \\
\text { ultimate benefactor }\end{array}$ & $\begin{array}{l}\text { What about the effect of durability on the community? } \\
\text { Benefits to the community are worth considering } \\
\text { heavily when deciding the method by which to build. } \\
\text { More durable housing benefits the community, } \\
\text { because it lasts longer and retains value. }\end{array}$ \\
\hline push & 2.05 & $\begin{array}{l}\text { Builder will emphasize touch and } \\
\text { feel qualities of product }\end{array}$ & $\begin{array}{l}\text { In most housing ads, houses are sold by things that } \\
\text { can be "touched," e.g. cabinets. Things like kitchens, } \\
\text { bathrooms, decks, basement, fireplace get some (but } \\
\text { less than } 100 \% \text { ) payback. These are all "touch and } \\
\text { see" items. Others that are not visible or not } \\
\text { appreciated as necessary do not get paid back. }\end{array}$ \\
\hline push & 2.14 & Buyer wants only see and feel stuff & $\begin{array}{l}\text { Higher income buyers will buy more durable products } \\
\text { because they look higher quality. People will upgrade } \\
\text { in things that they can physically perceive as being } \\
\text { better. Higher income people buy higher quality items. }\end{array}$ \\
\hline cert & 4.17 & $\begin{array}{l}\text { High maintenance is not a reliable } \\
\text { strategy for low frequency events; } \\
\text { need fail-safe systems }\end{array}$ & $\begin{array}{l}\text { A problem is that there are infrequent tests of } \\
\text { performance with these low probability events. If } \\
\text { there's a low probability, then there's no reason to do } \\
\text { high maintenance. There's a need to look at a fail-safe } \\
\text { system that gives warnings whenever the system is not } \\
\text { in shape. }\end{array}$ \\
\hline cert & 4.19 & $\begin{array}{l}\text { Especially for "high-frequency" } \\
\text { events? }\end{array}$ & $\begin{array}{l}\text { We need to focus on low frequency, low probability } \\
\text { events. Flooding drains, mildew, and fires are more } \\
\text { frequent. Low probability events need to be treated } \\
\text { differently. }\end{array}$ \\
\hline cert & 4.252 & (see notes) & Many buildings were retrofitted. \\
\hline cert & 4.33 & $\begin{array}{l}\text { Adherence to enhanced code raised } \\
\text { costs post-Andrew; adherence to } \\
\text { pre-Andrew code reduced losses. } \\
\text { Adherence produces better houses. }\end{array}$ & $\begin{array}{l}\text { In the case of Hurricane Andrew in Florida, the worst } \\
\text { hit part of a newly constructed area was where there } \\
\text { had been an agreement between the builder and } \\
\text { inspectors for self-enforcement of the codes. The self- } \\
\text { enforcement did not work, and the codes were not } \\
\text { enforced. But there was no attention paid to this } \\
\text { reason as the explanation for the damage in this area. } \\
\text { Instead, there was political hue and cry for more } \\
\text { stringent and more idiot-proof codes. But in other } \\
\text { areas, where existing codes were enforced, the homes } \\
\text { withstood the hurricane. }\end{array}$ \\
\hline
\end{tabular}




\begin{tabular}{|c|c|c|c|}
\hline 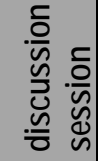 & 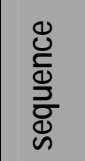 & 'flip chart' record & NIST notes \\
\hline risk & 5.20 & $\begin{array}{l}\text { Standard of acceptance-code } \\
\text { compliance/acceptance is very } \\
\text { important. }\end{array}$ & $\begin{array}{l}\text { Without thinking about it, house buyers are hyper- } \\
\text { conservative about new innovations. For them, } \\
\text { perception is reality. What matters is cost, location, } \\
\text { and style. They trust the code without exploring it. } \\
\text { Normally house buyers are happy enough assuming } \\
\text { that the code has been followed and that this } \\
\text { constitutes safety. If they see an innovation being } \\
\text { used, however, then it will raise their concern about its } \\
\text { code adherence. }\end{array}$ \\
\hline reg & 7.21 & $\begin{array}{l}\text { We need to determine what is an } \\
\text { "acceptable level of risk" and then } \\
\text { protect against it-code officials are } \\
\text { not stakeholders, but do have an } \\
\text { interest (fear of responsibility for } \\
\text { building failure?) }\end{array}$ & $\begin{array}{l}\text { What constitutes acceptable risk? The building } \\
\text { community and the fire safety people do not agree on } \\
\text { this. The regulator is not a stakeholder in the financial } \\
\text { sense, but they do have something to lose with any } \\
\text { code that is not prescriptive because they may be held } \\
\text { accountable if they make a mistake. }\end{array}$ \\
\hline
\end{tabular}

- Barrier/Incentive: (to market acceptance)

\begin{tabular}{|c|c|c|c|}
\hline 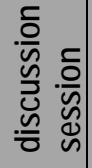 & 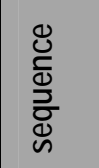 & 'flip chart' record & NIST notes \\
\hline push & 2.07 & Never recover total costs. & (see record) \\
\hline push & 2.102 & (see notes) & $\begin{array}{l}\text { People assume that the codes have it covered. They } \\
\text { trust the status quo. }\end{array}$ \\
\hline risk & 5.09 & $\begin{array}{l}\text { Code can be a barrier; may be used } \\
\text { by existing manufacturers to block } \\
\text { products. }\end{array}$ & $\begin{array}{l}\text { Codes can be used by incumbent producers to block } \\
\text { new products. }\end{array}$ \\
\hline reg & 7.03 & $\begin{array}{l}\text { Las Vegas as a model-regulators } \\
\text { must be open-minded to allow } \\
\text { range of designs in place }\end{array}$ & Regulators need to play a major role. \\
\hline reg & 7.33 & $\begin{array}{l}\text { The ICC and New Jersey } \\
\text { Rehabilitation Codes are steps in } \\
\text { the right direction. }\end{array}$ & $\begin{array}{l}\text { The ICC and the New Jersey Rehabilitation Code are } \\
\text { good examples. They are steps in the right direction. } \\
\text { There is a need for regulations. }\end{array}$ \\
\hline reg & 7.34 & $\begin{array}{l}\text { Going to statewide code increases } \\
\text { consistency in enforcement. }\end{array}$ & $\begin{array}{l}\text { If there were a move to statewide codes, there would } \\
\text { be better enforcement. }\end{array}$ \\
\hline reg & 7.341 & (see notes) & And predictability. \\
\hline
\end{tabular}

- Delivery system: (for housing and housing products)

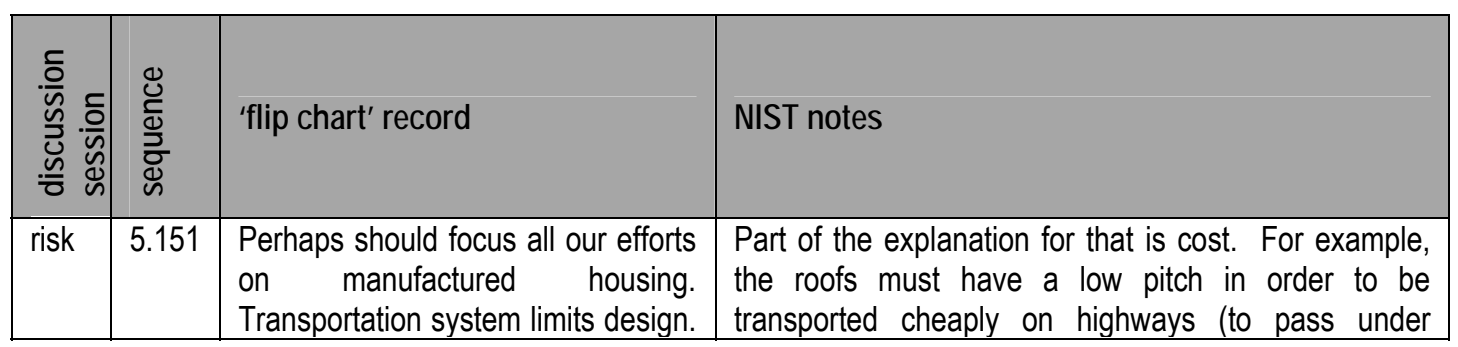




\begin{tabular}{|c|c|c|c|}
\hline 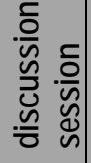 & 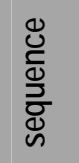 & 'flip chart' record & NIST notes \\
\hline & & $\begin{array}{l}\text { Weather limits design. Site } \\
\text { assembly will continue to exist. }\end{array}$ & bridges). But they are not pretty. \\
\hline cost & 8.05 & $\begin{array}{l}\text { This is what operation breakthrough } \\
\text { was supposed to do in the early } \\
70 \text { s. }\end{array}$ & $\begin{array}{l}\text { One example is the systems analysts at HUD with } \\
\text { Operation Breakthrough, where the government bore } \\
\text { some of the costs of innovation. }\end{array}$ \\
\hline cost & 8.27 & $\begin{array}{l}\text { See opportunity to do local pilot } \\
\text { projects. }\end{array}$ & $\begin{array}{l}\text { The systems for acceptance of new developments lie } \\
\text { with the local government. There is good potential for } \\
\text { local government to get involved in this new delivery } \\
\text { system. For example, San Diego, CA spent resources } \\
\text { to streamline the regulatory system. Montgomery } \\
\text { County, MD is also doing this. These are big budget } \\
\text { jurisdictions that can afford to do this. }\end{array}$ \\
\hline
\end{tabular}

- Market: supply-chain, builder, homebuyer, investor

\begin{tabular}{|c|c|c|c|}
\hline 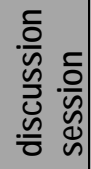 & 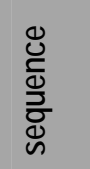 & 'flip chart' record & NIST notes \\
\hline ben & 1.36 & $\begin{array}{l}\text { For low-income, a } 3^{\text {rd }} \text { party has } \\
\text { joined the transaction and regulates } \\
\text { decision-making; not present in the } \\
\text { private-sector commercial market }\end{array}$ & $\begin{array}{l}\text { The non-profit building sector that the previous } \\
\text { speaker represents cares about the interest of the } \\
\text { homebuyers. In the for-profit market, we do not see } \\
\text { this. }\end{array}$ \\
\hline ben & 1.361 & (see notes) & $\begin{array}{l}\text { The non-profit builders make decisions in the interest } \\
\text { of the homebuyers. }\end{array}$ \\
\hline push & 2.043 & (see notes) & $\begin{array}{l}\text { Advertisements for homes do not provide detailed } \\
\text { information about windows, use of I-joists, etc. that are } \\
\text { used. They focus on the price of the homes and their } \\
\text { beauty. }\end{array}$ \\
\hline
\end{tabular}

- Metric: $1^{\text {st }}$, annual, life-cycle, time-horizon, units-of-measurement, uncertainty, market signal, rating scale

\begin{tabular}{|c|c|c|c|}
\hline 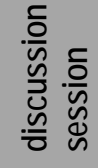 & 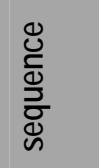 & 'flip chart' record & NIST notes \\
\hline comp & 3.041 & (see notes) & $\begin{array}{l}\text { Right now, mortgage payments are based on first } \\
\text { costs. }\end{array}$ \\
\hline comp & 3.341 & (see notes) & $\begin{array}{l}\text { With single-family homes, the assumption is that } \\
\text { equity being built up will pay for maintenance. }\end{array}$ \\
\hline cert & 4.07 & $\begin{array}{l}\text { Need to change terms of reference } \\
\text { for risk-100 year flood as likely } \\
\text { again next year as this year }\end{array}$ & $\begin{array}{l}\text { The perception of risk is that a } 100 \text { year flood cannot } \\
\text { happen two years in a row. There is no recognition } \\
\text { that the probabilities are independent from one year to } \\
\text { the next. When speaking of the } 100 \text { year flood, there } \\
\text { is the same probability at } 2003 \text { as } 2004 \text {. }\end{array}$ \\
\hline
\end{tabular}


- Perspective: interest, standing, constituents

\begin{tabular}{|c|c|c|c|}
\hline 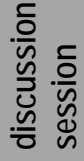 & 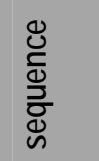 & 'flip chart' record & NIST notes \\
\hline comp & 3.171 & (see notes) & $\begin{array}{l}\text { One stake is that infrastructure costs are huge, } \\
\text { monolithic. It affects the local public interest so the } \\
\text { entire community has a stake when new housing is } \\
\text { built. }\end{array}$ \\
\hline cert & 4.281 & (see notes) & $\begin{array}{l}\text { Homeowners' associations also play a role in } \\
\text { monitoring maintenance. }\end{array}$ \\
\hline
\end{tabular}

- Product: development, test/evaluation, distribution, sale

\begin{tabular}{|c|c|c|c|}
\hline 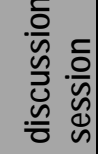 & 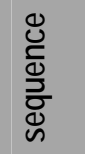 & 'flip chart' record & NIST notes \\
\hline risk & 5.18 & $\begin{array}{l}\text { We must determine what the } \\
\text { tendencies to failure are and test } \\
\text { those aspects of the product. }\end{array}$ & $\begin{array}{l}\text { There is a three-stage process. As Donald Rumsfeld } \\
\text { said, the worst thing is the "unknown unknown." }\end{array}$ \\
\hline cost & 8.131 & (see notes) & $\begin{array}{l}\text { Existing communities would prevent the lower-cost } \\
\text { housing from being built in the neighborhood. It would } \\
\text { be too disruptive }\end{array}$ \\
\hline
\end{tabular}

- Segmentation: MF/SF, new/existing, low-income/high-income

\begin{tabular}{|c|c|c|c|}
\hline 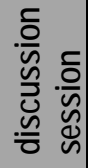 & 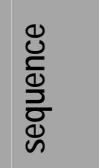 & 'flip chart' record & NIST notes \\
\hline ben & 1.35 & $\begin{array}{l}\text { Low-income buyer is a different } \\
\text { market; must balance: } \\
\text { - Current social taste } \\
\text { - Income limits } \\
\text { - Performance of home } \\
\text { Tradeoffs must be made and high } \\
\text { maintenance is a key issue }\end{array}$ & $\begin{array}{l}\text { The constraints in purchasing decisions are: style; first } \\
\text { cost (X \% of median income as defined by Fannie and } \\
\text { Freddie); performance of home (no high maintenance } \\
\text { requirements, no time bombs). For low-income } \\
\text { homebuyers, the life cycle is much longer, about } 10 \\
\text { years to } 15 \text { years, because they do not move as often. } \\
\text { What is acceptable for the lower-income buyer is the } \\
\text { first thing to consider. First costs are the second } \\
\text { consideration, and the performance of the home is } \\
\text { third. Durability is more important to this group } \\
\text { because they do not move and they may not be able to } \\
\text { afford expensive maintenance expenses such as } \\
\text { replacing a roof. Energy efficiency matters, too. But } \\
\text { first cost is also very important. }\end{array}$ \\
\hline cert & 4.231 & (see notes) & $\begin{array}{l}\text { Codes are driven by the rule that "one shalt not burn } \\
\text { your neighbor's home." }\end{array}$ \\
\hline cert & 4.243 & (see notes) & $\begin{array}{l}\text { If one person leaves the house burned down and does } \\
\text { not rebuild, then the entire neighborhood suffers. }\end{array}$ \\
\hline
\end{tabular}


- Value: cost, price, benefit

\begin{tabular}{|c|c|c|c|}
\hline 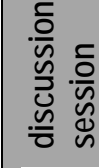 & 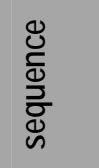 & 'flip chart' record & NIST notes \\
\hline ben & 1.02 & $\begin{array}{l}\text { Scales of concern: } \\
\text { - Materials and components } \\
\text { - Delivery system/satisfaction of } \\
\text { broader concerns } \\
\text { - Both economic and non- } \\
\text { economic factors } \\
\text { How do we quantify 'value'? } \\
\text { Must deal with marketplace issue of } \\
\text { 'pricing' (uncertainty of recoupment } \\
\text { of investment) }\end{array}$ & $\begin{array}{l}\text { Look at two scales of affordability: } \\
\text { 1. Components and materials } \\
\text { 2. System: at this scale, there is a more } \\
\text { complex relationship among stakeholders, } \\
\text { community, homeowners. } \\
\text { Must consider LCC in affordability. There are } \\
\text { economic and non-economic factors, but must make } \\
\text { them as quantified as possible with the components } \\
\text { and system. The challenge of the question of } \\
\text { affordability is to define, specify, and guide } \\
\text { affordability. There is the market issue of pricing, from } \\
\text { the raw materials to labor to the marketplace. One } \\
\text { factor in pricing is uncertainty. Therefore, decreasing } \\
\text { uncertainty may be one way of improving pricing (from } \\
\text { the affordability standpoint). Is cost (of materials, } \\
\text { construction) reflected in pricing? }\end{array}$ \\
\hline ben & 1.07 & $\begin{array}{l}\text { Cost will determine whether it is } \\
\text { built }\end{array}$ & $\begin{array}{l}\text { In the suburban Maryland community of Montgomery } \\
\text { Village, there is a requirement that a builder seeking a } \\
\text { permit must devote } 20 \% \text { of the construction to } \\
\text { affordable housing. The county definition of affordable } \\
\text { housing is based on the rent or purchase price of the } \\
\text { housing. }\end{array}$ \\
\hline push & 2.171 & (see notes) & $\begin{array}{l}\text { Increasing density is the source of the biggest savings. } \\
\text { Land and infrastructure are expensive. With } \\
\text { Montgomery Village, MD's } 20 \% \text { affordable housing } \\
\text { rule that someone previously mentioned, you get } \\
\text { bonus density. }\end{array}$ \\
\hline
\end{tabular}

\section{Lenders}

- Attribute: affordability, durability, safety, etc. (flexibility, substitutability, customizability)

\begin{tabular}{|c|c|c|c|}
\hline 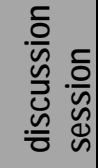 & 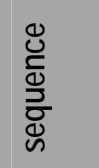 & 'flip chart' record & NIST notes \\
\hline ben & 1.201 & (see notes) & Financiers also have a stake. \\
\hline ben & 1.27 & $\begin{array}{l}\text { Biggest problem is functional } \\
\text { obsolescence } \\
\text { - Build in flexibility to change } \\
\text { - Today will not be tomorrow in } \\
\text { all dimensions, including } \\
\text { operating cost concerns }\end{array}$ & $\begin{array}{l}\text { Flexibility of housing design is important. The big } \\
\text { problem is not structural deterioration of a home. It is } \\
\text { functional obsolescence. Therefore, need to build } \\
\text { flexibility into the house and its design for future } \\
\text { changes, including those not motivated by operating } \\
\text { costs. }\end{array}$ \\
\hline
\end{tabular}




\begin{tabular}{|c|c|c|c|}
\hline 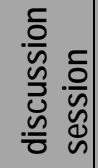 & 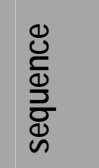 & 'flip chart' record & NIST notes \\
\hline cert & 4.25 & $\begin{array}{l}\text { Northridge quake: soft-story } \\
\text { collapse was the problem. }\end{array}$ & $\begin{array}{l}\text { Earthquake insurance was withdrawn for condos in } \\
\text { southern California after the Northridge earthquake. } \\
\text { What was the technical impact? }\end{array}$ \\
\hline cert & 4.261 & (see notes) & Or outcry from the insurers. \\
\hline cert & 4.31 & $\begin{array}{l}\text { What is quality level for 'affordable' } \\
\text { housing? Safer means higher cost; } \\
\text { will be the same for all attributes. }\end{array}$ & $\begin{array}{l}\text { Stricter codes reduce affordability. There is a lot of } \\
\text { housing that is affordable that is unlivable. What is the } \\
\text { minimum standard? Here, we are talking about } \\
\text { increasing the minimum standard. Can you achieve } \\
\text { the performance with less expensive materials? What } \\
\text { is the quality level to be achieved? Houses are better } \\
\text { built now and cost less. It is necessary to change } \\
\text { costs to reflect the value of the housing. Increasing } \\
\text { standards would increase costs greatly, which would } \\
\text { lead to a decrease in the availability of affordable } \\
\text { housing. }\end{array}$ \\
\hline cert & 4.331 & (see notes) & A HUD study also showed this with seismic events. \\
\hline cert & 4.333 & (see notes) & $\begin{array}{l}\text { If these changes were to be made, one effect would be } \\
\text { to increase the hurdle rate of the house and make } \\
\text { ownership less affordable. }\end{array}$ \\
\hline
\end{tabular}

- Barrier/Incentive: (to market acceptance)

\begin{tabular}{|c|c|c|c|}
\hline 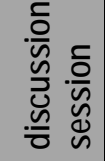 & 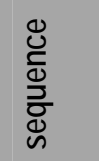 & 'flip chart' record & NIST notes \\
\hline ben & 1.23 & $\begin{array}{l}\text { Buyers would consider information } \\
\text { if informed }\end{array}$ & $\begin{array}{l}\text { If buyers knew durability affected the underwriting } \\
\text { decision, durability would matter to them. An example } \\
\text { is energy-efficient mortgages. }\end{array}$ \\
\hline comp & 3.33 & $\begin{array}{l}\text { May be home keeper mortgage- } \\
\text { borrower is essentially buying } \\
\text { insurance (on performance.?) }\end{array}$ & $\begin{array}{l}\text { This could be what is called the "Homekeeper } \\
\text { Mortgage." It sets a bar where the bar is an insurance } \\
\text { policy. The homeowner pays a fee into escrow every } \\
\text { month. If an element of the home goes bad, then the } \\
\text { insurance will pay to repair it. It is insurance for } \\
\text { durability. The fee will determine the effect on the } \\
\text { mortgage. }\end{array}$ \\
\hline cert & 4.04 & $\begin{array}{l}\text { Risk-based insurance may have } \\
\text { contrary effect of increasing costs } \\
\text { to those that can least afford }\end{array}$ & $\begin{array}{l}\text { Insurers pool risk. Premiums are based on worst-case } \\
\text { scenarios. Insurers' concern is, what is their } \\
\text { exposure? Risk premiums are a means of getting rid } \\
\text { of the cross subsidization of the high risk by the low } \\
\text { risk. If risk premiums were used, we would probably } \\
\text { see the lowest income owners paying the highest } \\
\text { premiums. Also, underwriting would be much more } \\
\text { difficult. It would have to be done on a case-by-case } \\
\text { basis. }\end{array}$ \\
\hline SOC & 6.111 & (see notes) & $\begin{array}{l}\text { But the cost of the disposal is not internalized at the } \\
\text { time of purchase of the product because the purchase } \\
\text { price is separate from the end-of-year disposal fee. }\end{array}$ \\
\hline
\end{tabular}


- Delivery system: (for housing and housing products)

No comments.

- Market: supply-chain, builder, homebuyer, investor

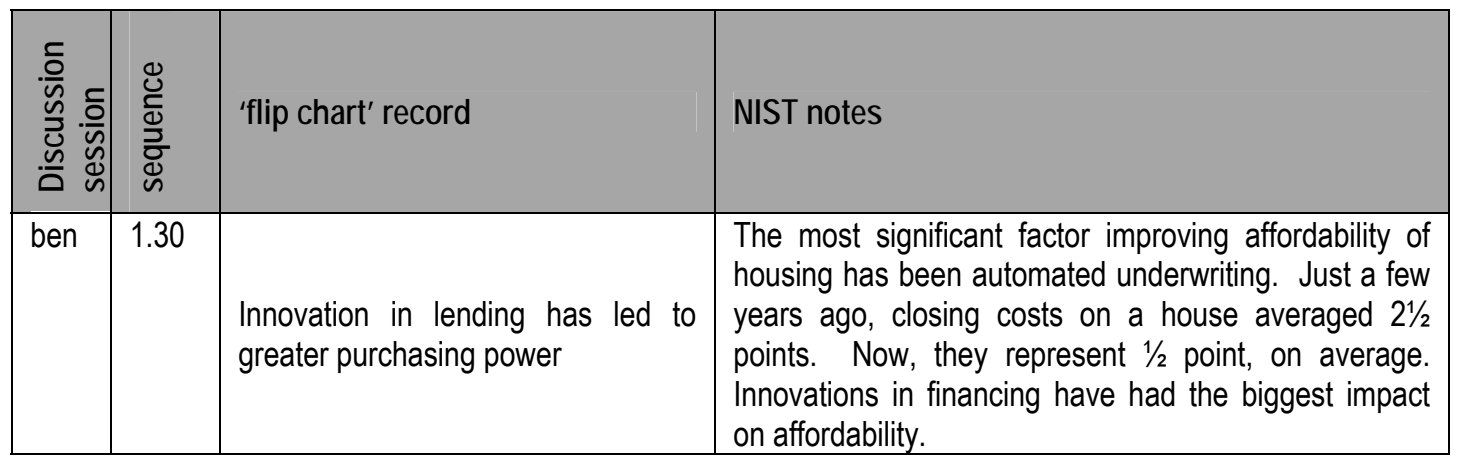

- Metric: $1^{\text {st }}$, annual, life-cycle, time-horizon, units-of-measurement, uncertainty, market signal, rating scale

\begin{tabular}{|c|c|c|c|}
\hline 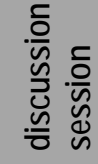 & 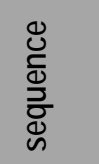 & 'flip chart' record & NIST notes \\
\hline ben & 1.05 & $\begin{array}{l}\text { There are indirect relationships } \\
\text { between the cost of production and } \\
\text { the supply of housing }\end{array}$ & $\begin{array}{l}\text { Cost of materials is related to the price of the house } \\
\text { because the going level affects how much gets built } \\
\text { (supply of housing). The cost of building a house } \\
\text { determines if the house gets built or not. The market } \\
\text { defines where we go. }\end{array}$ \\
\hline comp & 3.25 & $\begin{array}{l}\text { Difficulty costing rare events? No, it } \\
\text { is a known actuarial experience } \\
\text { base. }\end{array}$ & (see record) \\
\hline comp & 3.254 & (see notes) & $\begin{array}{l}\text { One reason this is difficult is because we do not know } \\
\text { how to price a rare event. }\end{array}$ \\
\hline comp & 3.257 & (see notes) & One example is lead paint. It was costly to change. \\
\hline comp & 3.34 & $\begin{array}{l}\text { In MF housing, debt ratio is } \\
\text { determinant-must consider the } \\
\text { viability of the structure (due } \\
\text { diligence) } \\
\text { Home inspections could serve a } \\
\text { similar purpose for SF }\end{array}$ & $\begin{array}{l}\text { This is another example of innovation in mortgage } \\
\text { lending. Underwriting decisions for SF homes are } \\
\text { based on creditworthiness of the borrower, not the } \\
\text { value of the asset. If the consumer values it, they will } \\
\text { pay for it. With multi-family housing, the situation is } \\
\text { different. In this case, lenders look at the value of the } \\
\text { asset, not creditworthiness of the borrower, when } \\
\text { making underwriting decision. They look at the } \\
\text { viability of the structure as the ratio of liability to the } \\
\text { value of the asset. }\end{array}$ \\
\hline comp & 3.363 & (see notes) & $\begin{array}{l}\text { Foreclosure is rare: has nothing to do with the actual } \\
\text { house, but the credit of the individual. Freddie Mac } \\
\text { has a default rate of less than } 1 \% \text {, so foreclosure is } \\
\text { not a factor for most mortgages. The issue is whether } \\
\text { the market will move the house. There is no bubble in }\end{array}$ \\
\hline
\end{tabular}




\begin{tabular}{|c|c|c|c|}
\hline 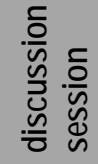 & 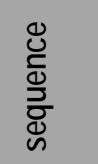 & 'flip chart' record & NIST notes \\
\hline & & & the housing market. \\
\hline cert & 4.022 & (see notes) & $\begin{array}{l}\text { The occurrence of an event affects perceptions about } \\
\text { its probability. If a rare event occurs, it makes people } \\
\text { perceive that the event is more likely to occur again. }\end{array}$ \\
\hline cert & 4.15 & $\begin{array}{l}\text { It's a time horizon consideration-if } \\
\text { beyond mine, I don't care. }\end{array}$ & $\begin{array}{l}\text { LCC is not a good approach because time horizons } \\
\text { are short. The thinking is that a homeowner can } \\
\text { forego maintenance for } 5 \text { years because the } \\
\text { consequences will not be observable in that time, and } \\
\text { can sell with no penalty. }\end{array}$ \\
\hline cert & 4.372 & (see notes) & $\begin{array}{l}\text { Can we increase quality and performance while } \\
\text { reducing cost? }\end{array}$ \\
\hline risk & 5.01 & $\begin{array}{l}\text { What types of uncertainties? } \\
\text { - Unforeseen costs } \\
\text { - Durability of value } \\
\text { - Consistency of measurement } \\
\text { capability } \\
\text { What types of affordability? }\end{array}$ & $\begin{array}{l}\text { - Interaction between uncertainty and affordability } \\
\text { components. } \\
\text { - Issue: Will the value be maintained in the long run? } \\
\text { Will the house hold its value if the component falls out } \\
\text { of trend or physically falls out? } \\
\text { - Do all innovations have to be held to the same } \\
\text { affordability standards? }\end{array}$ \\
\hline SOC & 6.14 & $\begin{array}{l}\text { How do you choose between } \\
\text { regulation and not-you need a } \\
\text { metric to decide. }\end{array}$ & $\begin{array}{l}\text { Assume that technology produces some good. What } \\
\text { is the metric to link these two? }\end{array}$ \\
\hline SOC & 6.22 & $\begin{array}{l}\text { The durability equation as outlined } \\
\text { does not address social costs (the } \\
\text { key parameter of this session). }\end{array}$ & $\begin{array}{l}\text { The equation also would not address social costs, } \\
\text { such as environmental costs. }\end{array}$ \\
\hline
\end{tabular}

- Perspective: interest, standing, constituents

\begin{tabular}{|c|c|c|c|}
\hline 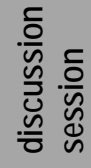 & 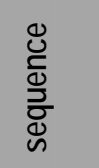 & 'flip chart' record & NIST notes \\
\hline comp & 3.21 & $\begin{array}{l}\text { Codes can only address a minimum } \\
\text { level of safety }\end{array}$ & $\begin{array}{l}\text { But what is the purpose of the codes? Every ratchet } \\
\text { up of the code ratchets up the cost. }\end{array}$ \\
\hline cert & 4.121 & (see notes) & $\begin{array}{l}\text { Maintenance is a major concern relating to the person } \\
\text { who is paying for it at the moment that it occurs. } \\
\text { Consider } 1 \% \text { of purchase price }+ \text { costs of } \\
\text { improvements every year to stabilize the community. }\end{array}$ \\
\hline cert & 4.282 & (see notes) & How does this relate to affordability? \\
\hline SOC & 6.01 & $\begin{array}{l}\text { There is a difference between } \\
\text { 'valuing' and 'monetizing' } \\
\text { In terms of stakeholder values- } \\
\text { there is difference between 'general } \\
\text { stakeholders' (e.g. regulators and } \\
\text { repairmen) and 'stakeholders with } \\
\text { standing' } \\
\text { In terms of distribution of costs and } \\
\text { benefits-FNMA is far more } \\
\text { concerned with negative impacts on } \\
\text { low-income segments (much more }\end{array}$ & $\begin{array}{l}\text { - Is it possible to make a quantitative judgment } \\
\text { based on a qualitative factor? } \\
\text { - Should regulators be considered stakeholders? } \\
\text { They are not necessarily stakeholders when } \\
\text { concerning costs. } \\
\text { - Do you consider costs to repairmen as new } \\
\text { technologies are implemented? } \\
\text { - Fannie Mae is concerned with regulations having } \\
\text { negative impacts towards low-income housing } \\
\text { (crime, education). Fannie Mae is more }\end{array}$ \\
\hline
\end{tabular}




\begin{tabular}{|c|c|c|c|}
\hline 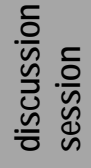 & 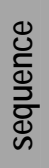 & 'flip chart' record & NIST notes \\
\hline & & $\begin{array}{l}\text { susceptible to adverse effects) } \\
\text { In terms of social costs-at what } \\
\text { geographic/political level are they } \\
\text { considered? } \\
\text { Social value is highly subjective- } \\
\text { New York City studied costs that } \\
\text { accrued to the city-city bore costs } \\
\text { disproportionately; benefits were } \\
\text { more widespread. How do you } \\
\text { value benefits like self-esteem? }\end{array}$ & $\begin{array}{l}\text { interested in increased cost on lower income } \\
\text { families - this is the group where negative } \\
\text { externalities are greatest. } \\
\text { For social costs and benefits, you need to know } \\
\text { what area you are talking about? Every } \\
\text { stakeholder places different values on social } \\
\text { costs. Every person/place places a different } \\
\text { value on a social outcome. } \\
\text { Cost savings on criminal justice system in New } \\
\text { York City is support of housing for the homeless } \\
\text { was instated - how do you determine the value of } \\
\text { a quality like self-esteem? No value for self- } \\
\text { esteem has been determined for giving shelter to } \\
\text { the homeless. }\end{array}$ \\
\hline
\end{tabular}

- Product: development, test/evaluation, distribution, sale

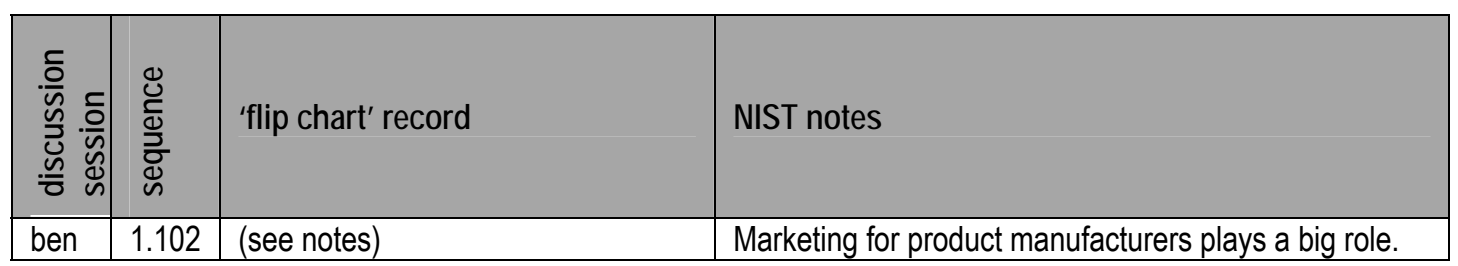

- Segmentation: $\mathrm{MF} / \mathrm{SF}$, new/existing, low-income/high-income

\begin{tabular}{|c|c|c|c|}
\hline 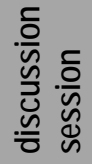 & 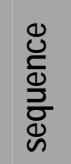 & 'flip chart' record & NIST notes \\
\hline comp & 3.03 & $\begin{array}{l}\text { Discussions have had a single } \\
\text { family emphasis while most } \\
\text { affordable housing is MF } \\
\text { MF delivery system explicitly } \\
\text { considers age, service life, and } \\
\text { condition at resale }\end{array}$ & $\begin{array}{l}\text { Multi-family is the biggest component of affordable } \\
\text { housing. In this segment, underwriting explicitly takes } \\
\text { into account the life stage of housing. }\end{array}$ \\
\hline
\end{tabular}

- Value: cost, price, benefit

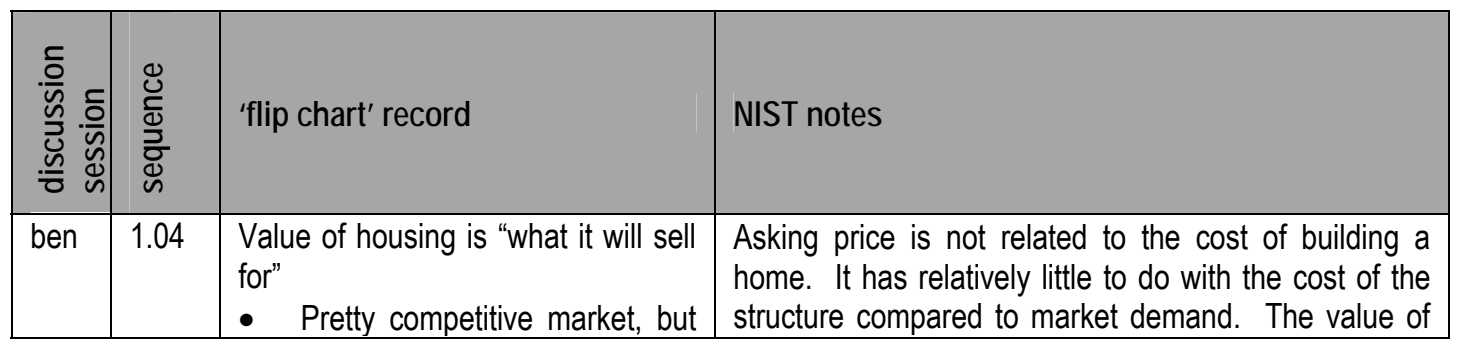




\begin{tabular}{|c|c|c|c|}
\hline 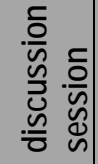 & 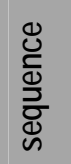 & 'flip chart' record & NIST notes \\
\hline & & $\begin{array}{l}\text { cost of building (production } \\
\text { does not set price) } \\
\text { - Price has little to do with } \\
\text { structure } \\
\text { - Is affordability the "ability to } \\
\text { pay" or the "cost to build" }\end{array}$ & $\begin{array}{l}\text { the house is what it will sell for. "Cheap" housing can } \\
\text { become very expensive, because the price has little to } \\
\text { do with the structure. The market determines the cost. }\end{array}$ \\
\hline ben & 1.10 & $\begin{array}{l}\text { Individual choices do not effect } \\
\text { expected resale value (time horizon } \\
\text { can be critical to decision making) }\end{array}$ & $\begin{array}{l}\text { The average homeowners stays in their home about } \\
5 \text { years. The life cycle is short and affects the choices } \\
\text { of homeowners, too. The homeowner needs to see } \\
\text { the net benefit of the product. }\end{array}$ \\
\hline ben & 1.40 & $\begin{array}{l}\text { If it is worth something, lenders will } \\
\text { underwrite it. }\end{array}$ & $\begin{array}{l}\text { The market will price durability. Lenders will not } \\
\text { because it is not part of the (lending) price. } \\
\text { Underwriting for single-family homes depends on the } \\
\text { ability to repay the loan. }\end{array}$ \\
\hline
\end{tabular}

\section{Builders}

- Attribute: affordability, durability, safety, etc. (flexibility, substitutability, customizability)

\begin{tabular}{|c|c|c|c|}
\hline 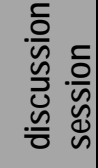 & 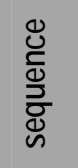 & 'flip chart' record & NIST notes \\
\hline push & 2.21 & $\begin{array}{l}\text { Study of density health effects may } \\
\text { be a lever for higher density. May } \\
\text { be a pull factor but government } \\
\text { must lead/drive education. }\end{array}$ & $\begin{array}{l}\text { There was a New York Times article about zoning as } \\
\text { an explanation for some of the health and community } \\
\text { problems in this country. The conclusion was that if } \\
\text { zoning allowed more density and mixed-use } \\
\text { neighborhoods, people could walk more and be } \\
\text { healthier and have a greater community identification. } \\
\text { Kentlands, a planned community in Montgomery } \\
\text { County, Maryland, is an example. This could lead to } \\
\text { more sidewalks and commercial and residential areas } \\
\text { would not be segregated. This leads to less driving, } \\
\text { less obesity. } \\
\text { Health has deteriorated because of zoning. Are people } \\
\text { healthier in small towns? Could benefits like this pay } \\
\text { for innovations? }\end{array}$ \\
\hline push & 2.27 & (see notes) & Another push is financial incentive. \\
\hline push & 2.30 & (see notes) & $\begin{array}{l}\text { With NAHB surveys, we have to be careful in framing } \\
\text { the questions. }\end{array}$ \\
\hline cert & 4.02 & 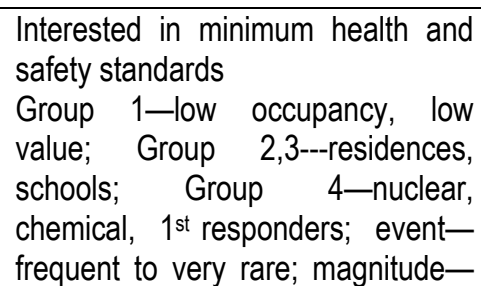 & $\begin{array}{l}\text { - The state of South Carolina does not believe their } \\
\text { earthquake provision is where it should be. Large } \\
\text { events, such as floods, for example, caused flood } \\
\text { claims to be changed. Insurance companies go to the } \\
\text { re-insurer. Premiums are based on worst-case } \\
\text { scenarios. It's difficult to figure risk-based premiums. } \\
\text { Some people will pay more and some will pay less. }\end{array}$ \\
\hline
\end{tabular}




\begin{tabular}{|c|c|c|c|}
\hline 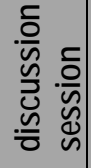 & 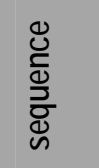 & 'flip chart' record & NIST notes \\
\hline & & small to large & $\begin{array}{l}\text { The homeowner who can least afford it, pays the most. } \\
\text { - Balance magnitude of improbable event and } \\
\text { magnitude of possible damage. (see table handout) i.e. } \\
\text { earthquake is less risk tolerant than high winds } \\
\text { - If a rare event occurs, it makes people perceive that } \\
\text { the event is more likely to occur again. }\end{array}$ \\
\hline cert & 4.10 & $\begin{array}{l}\text { Cannot rely on maintenance for } \\
\text { operation-product will fail }\end{array}$ & $\begin{array}{l}\text { The typical homebuyer prefers zero maintenance. } \\
\text { Most are in the first category. }\end{array}$ \\
\hline cert & 4.14 & $\begin{array}{l}\text { Banks require property tax escrow } \\
\text { (banks protect investment by forcing } \\
\text { compliance), why not similar } \\
\text { approach for maintenance? }\end{array}$ & $\begin{array}{l}\text { Mortgage lenders build in escrow for property tax and } \\
\text { insurance premiums. The same could be done for } \\
\text { maintenance if believe that personal responsibility is } \\
\text { not reliable. }\end{array}$ \\
\hline cert & 4.251 & (see notes) & Now can't build in some places. \\
\hline cert & 4.334 & (see notes) & $\begin{array}{l}\text { Codes are merely an agreed minimal acceptable } \\
\text { standard. }\end{array}$ \\
\hline reg & 7.14 & $\begin{array}{l}\text { Before you can define 'affordability', } \\
\text { you need to define 'safety' } \\
\text { ("acceptable risk"?). There is } \\
\text { currently no accepted credible } \\
\text { definition; nothing to push off from. } \\
\text { Local code officials do not know } \\
\text { what the code means in terms of } \\
\text { performance. Until decision-making } \\
\text { approval is removed, innovation will } \\
\text { not occur. }\end{array}$ & $\begin{array}{l}\text { Before you define affordability, must define the } \\
\text { standard for safety. Should it be "no injury or death"? } \\
\text { This is a barrier. There is no measure to bounce } \\
\text { affordability off of. Only the nuclear power industry has } \\
\text { specific criteria about safety. As with the energy code, } \\
\text { until there was a standard, it was not possible to } \\
\text { assess the relationship between affordability and } \\
\text { energy efficiency. The lack of credible standards } \\
\text { makes it impossible to enforce. Without a clear } \\
\text { definition of safety (and/or affordability, for instance) in } \\
\text { the context of a prescriptive set of code provisions, the } \\
\text { introduction and use of performance criteria may } \\
\text { decrease. Determining compliance with performance } \\
\text { type regulations can be more difficult and require } \\
\text { additional training for the code official. Also, many } \\
\text { local officials do not understand the codes they are } \\
\text { trying to enforce. They do not want to take a chance } \\
\text { on a new product. }\end{array}$ \\
\hline reg & 7.211 & (see notes) & $\begin{array}{l}\text { Must encourage use of the evaluation services for this. } \\
\text { The inspector should not have to make the decision. }\end{array}$ \\
\hline
\end{tabular}

- Barrier/Incentive: (to market acceptance)

\begin{tabular}{|c|c|c|c|}
\hline 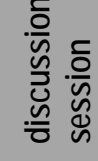 & 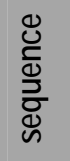 & 'flip chart' record & NIST notes \\
\hline ben & 1.44 & $\begin{array}{l}\text { Regulation is the key (represents } \\
30 \% \text { of the cost of housing) } \\
\text { - Recognize that existing stock } \\
\text { dwarf new construction } \\
\text { (replacement is } 2 \% \text { to } 4 \% \text { per } \\
\text { year) } \\
\text { - Recognize that delivery }\end{array}$ & $\begin{array}{l}\text { Regulation accounts for } 30 \% \text { of the cost of housing. } \\
\text { Regulation drives a lot of the first cost. These } \\
\text { numbers are from the Kemp Commission Report. }\end{array}$ \\
\hline
\end{tabular}




\begin{tabular}{|c|c|c|c|}
\hline 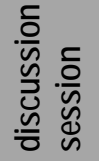 & 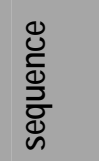 & 'flip chart' record & NIST notes \\
\hline & & $\begin{array}{l}\text { systems for innovation in new } \\
\text { and existing housing are very } \\
\text { different }\end{array}$ & \\
\hline ben & 1.45 & (see notes) & Land availability and regulations do drive costs. \\
\hline ben & 1.46 & (see notes) & $\begin{array}{l}\text { A second point is that the existing housing stock } \\
\text { dwarfs new stock. These older homes are not going } \\
\text { away. They are just getting older. Even replacing } \\
2 \% \text { to } 3 \% \text { of this stock annually means that these } \\
\text { houses will be around in } 20 \text { years, } 30 \text { years, } 40 \text { years, } \\
\text { even } 60 \text { years from now. How can we extend the } \\
\text { dynamic constrained optimization to } 60 \text { years? Other } \\
\text { considerations are that the average age of a house } \\
\text { remodeler is } 47 \text {, and the average person working in } \\
\text { construction is not U.S. born. }\end{array}$ \\
\hline push & 2.08 & $\begin{array}{l}\text { May not get a nickel of initial costs } \\
\text { back }\end{array}$ & (see record) \\
\hline push & 2.16 & $\begin{array}{l}\text { How do you introduce efficiencies } \\
\text { into product delivery system: } \\
\text { - } 70 \text { s-tools } \\
\text { - '80s-hard products/pre-cut } \\
\text { studs, dimensional shingles } \\
\text { - '90s--technology } \\
\text { - '00s-QC management/ } \\
\text { business systems } \\
\text { Non-building considerations lead in } \\
\text { importance today; } 70 \% \\
\text { tradesmen have no employees }\end{array}$ & $\begin{array}{l}\text { This is how I see, very roughly and very generally, the } \\
\text { recent history of innovations in the housing industry. } \\
\text { In the } 1970 \text { s, there were innovations in the tools and } \\
\text { equipment used in construction. The 1980s saw } \\
\text { innovations in hard products, such as pre-cut studs, } \\
\text { OSB, and dimensional shingles. The } 1990 \text { s saw } \\
\text { innovations in information and communications } \\
\text { technology, with the use of the internet and cell } \\
\text { phones. I predict that in the } 2000 \text { s, the key } \\
\text { innovations will be in business systems, organization, } \\
\text { structure, management, and quality control. Only the } \\
\text { big public companies will pay attention to } \\
\text { management, because most construction companies } \\
\text { are one-man shops with no employees and therefore } \\
\text { no management needs. As an industry, we have a } \\
\text { group that is not business savvy. We need to make } \\
\text { the tradesmen more efficient. }\end{array}$ \\
\hline push & 2.20 & $\begin{array}{l}\text { What are 'accidental' attributes/ } \\
\text { barriers to innovation? }\end{array}$ & $\begin{array}{l}\text { Some see innovations adopted by accident. For } \\
\text { example, the demand for houses on concrete slabs in } \\
\text { Phoenix. People there will not accept crawl spaces. }\end{array}$ \\
\hline push & 2.24 & $\begin{array}{l}\text { Must be somewhat cautious; be } \\
\text { careful of number of innovations } \\
\text { bundled together }\end{array}$ & $\begin{array}{l}\text { Must be careful about the number of technological } \\
\text { innovations that are shown to buyers. Most do not } \\
\text { want it. }\end{array}$ \\
\hline comp & 3.071 & (see notes) & Do state regulations play a part in this? \\
\hline comp & 3.10 & $\begin{array}{l}\text { No incentives from insurers, though } \\
\text { insurers want upgraded } \\
\text { performance through } \text { code } \\
\text { requirements. }\end{array}$ & $\begin{array}{l}\text { But any decrease would have to be balanced by an } \\
\text { increase somewhere else. More restrictive codes are } \\
\text { the easiest way for insurers to protect themselves } \\
\text { from losses. States control the insurance industry; } \\
\text { they must allow insurance companies to price on risk. } \\
\text { State Farm, for example, is a big player. It can } \\
\text { influence the marketplace. It has threatened to pull } \\
\text { out of Texas and other states because it was too } \\
\text { exposed there. }\end{array}$ \\
\hline comp & 3.271 & (see notes) & The price affected how quickly it was adopted and \\
\hline
\end{tabular}




\begin{tabular}{|c|c|c|c|}
\hline 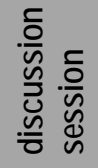 & 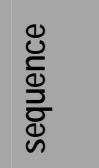 & 'flip chart' record & NIST notes \\
\hline & & & penetrated the market. \\
\hline comp & 3.28 & $\begin{array}{l}\text { Regulators are in place to protect } \\
\text { public interest, but ("lag v stove bolt } \\
\text { prescription") we've created a } \\
\text { stakeholder we did not want. }\end{array}$ & $\begin{array}{l}\text { Regulators are there to protect the public and not to } \\
\text { have their own interest. But this is not always how it } \\
\text { plays out. For example, I had to replace } 1 / 2 \text {-inch } \\
\text { ( } 12.7 \mathrm{~mm}) \text { lag bolts installed with nut and washer with } \\
3 / 8 \text {-inch }(9.525 \mathrm{~mm}) \text { bolts on a cathedral ceiling } \\
\text { because the code called for the } 3 / 8 \text {-inch }(9.525 \mathrm{~mm}) \\
\text { bolts, and code official demanded this. Replacing } \\
\text { these bolts took about } 10 \text { labor hours and } \$ 150 \text { in } \\
\text { materials. Would there have been a difference in } \\
\text { performance if the } 1 / 2 \text {-inch ( } 12.7 \mathrm{~mm}) \text { lag bolts with nut } \\
\text { and washer had stayed? }\end{array}$ \\
\hline cert & 4.143 & (see notes) & $\begin{array}{l}\text { Educating people is the key. People do not read } \\
\text { instruction manuals. For example, I know someone } \\
\text { who refuses to and therefore cannot operate the VCR. }\end{array}$ \\
\hline cert & 4.36 & $\begin{array}{l}\text { Future benefits uncertain or } \\
\text { contingent on future actions (e.g. } \\
\text { zoning) impediments to affordable } \\
\text { product. Correlation to increased } \\
\text { cost and reduced risk. }\end{array}$ & $\begin{array}{l}\text { There is a need to consider affordability impacts when } \\
\text { going from a small lot to a large lot. An example is } \\
\text { consequences of septic failure on ground water } \\
\text { quality. Does the reduction in risk correlate to } \\
\text { increase in cost? What is a reasonable tradeoff for } \\
\text { risk? Insurance companies pushed for changes to } \\
\text { double lot sizes. }\end{array}$ \\
\hline cert & 4.362 & (see notes) & $\begin{array}{l}\text { There are a number of positive incentives in improving } \\
\text { and following codes and zoning. The improvement } \\
\text { may trade off with other incentives. }\end{array}$ \\
\hline risk & 5.22 & $\begin{array}{l}\text { Big problem for builder is how to } \\
\text { train producers installers } \\
\text { (laborers); ability to train will be a } \\
\text { big component of acceptance. } \\
\text { (internet opportunity?) }\end{array}$ & $\begin{array}{l}\text { Need education/training and uniform installation. } \\
\text { There is a lack of consensus about the proper } \\
\text { method. The ability to train is not there. How can this } \\
\text { training be delivered? Must simplify delivery of } \\
\text { content (such as through the Internet). }\end{array}$ \\
\hline risk & 5.24 & $\begin{array}{l}\text { Supply-chain liability will/should fix } \\
\text { problem. }\end{array}$ & $\begin{array}{l}\text { It is the supply chain that will eventually improve the } \\
\text { testing and research situations. The solution must be } \\
\text { found in the supply and distribution chain because } \\
\text { that is where the liability lies. It is where the supply } \\
\text { and labor interface. There has been a decline of } \\
\text { vocational training in the U.S. It has been taken out of } \\
\text { high schools. The unions are not providing or } \\
\text { requiring it. They do not know how to put things in. } \\
\text { So who will benefit from labor improvements? Use } \\
\text { the supply chain as a risk management method. }\end{array}$ \\
\hline SOC & 6.10 & $\begin{array}{l}\text { We should focus on positive } \\
\text { incentives, like tax credits, etc. } \\
\text { Mitigation is purely regulation } \\
\text { Insurance companies have an } \\
\text { opportunity to reduce their own risk } \\
\text { through risk-based underwriting } \\
\text { (encourage rather than force } \\
\text { acceptance) }\end{array}$ & $\begin{array}{l}\text { There are government incentives, including tax credits } \\
\text { and land use (higher density, cost of land). Some of } \\
\text { the mitigation that was just described are mandatory, } \\
\text { not incentive-based. Insurance can provide } \\
\text { incentives with lower premiums in some areas to } \\
\text { reflect risk, but it is regulated by states. States have } \\
\text { an opportunity to affect this. We need a metric to } \\
\text { measure these technologies (which one is better?). } \\
\text { Social benefits will come from what the government } \\
\text { recognizes as important (for example, provide a free }\end{array}$ \\
\hline
\end{tabular}




\begin{tabular}{|c|c|c|c|}
\hline 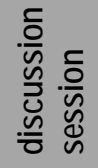 & 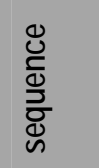 & 'flip chart' record & NIST notes \\
\hline & & & $\begin{array}{l}\text { thermostat). Encourage, rather than enforce, through } \\
\text { different costs. }\end{array}$ \\
\hline reg & 7.10 & $\begin{array}{l}\text { Want to reinforce notion of looking } \\
\text { at other industries for guidance: } \\
\text { there is a strong trend that } \\
\text { deregulation spurs innovation }\end{array}$ & $\begin{array}{l}\text { With homebuilding, can look at whether regulations } \\
\text { have an effect on innovation. There are many } \\
\text { regulated industries that became deregulated. Could } \\
\text { see whether a spurt of innovation followed the } \\
\text { deregulation. }\end{array}$ \\
\hline reg & 7.18 & $\begin{array}{l}\text { Only occurs through appeals } \\
\text { process-practitioners realize that } \\
\text { you cannot truly build to code. }\end{array}$ & $\begin{array}{l}\text { I have found that state-level code people in one } \\
\text { Midwest state are responsive if local officials are } \\
\text { resistant. In some other states, the only remedy if a } \\
\text { local code official disagrees or resists is the appeals } \\
\text { process. The truth is that strict adherence to the code } \\
\text { is impossible. }\end{array}$ \\
\hline reg & 7.25 & $\begin{array}{l}\text { Some code officials do not even } \\
\text { use code language, much less NES } \\
\text { reports in making decisions. }\end{array}$ & $\begin{array}{l}\text { Some code officials disagree with the code and will } \\
\text { not adhere. }\end{array}$ \\
\hline reg & 7.251 & (see notes) & Schenectady is one example. \\
\hline reg & 7.26 & $\begin{array}{l}\text { Reports are limited only to existing } \\
\text { code requirements and do not test } \\
\text { against purposes of innovation } \\
\text { (whatever those may be, such as } \\
\text { durability); do not rely only on } \\
\text { reports. }\end{array}$ & $\begin{array}{l}\text { There are limits to ESRs. They do not address } \\
\text { durability or affordability. The evaluations are only for } \\
\text { the adherence to the codes that are existing. The } \\
\text { code/evaluation process calls for extraneous testing } \\
\text { that is not appropriate for the material in many cases. }\end{array}$ \\
\hline reg & 7.28 & $\begin{array}{l}\text { Some AHJs require engineering } \\
\text { certification for each installation-a } \\
\text { very expensive burden. }\end{array}$ & $\begin{array}{l}\text { For some officials, if you get the engineer's seal on } \\
\text { the design, then you can use it. But this is costly. So } \\
\text { this is still a barrier to adoption of new technology. }\end{array}$ \\
\hline reg & 7.30 & $\begin{array}{l}\text { Risk insurance coverage (for } \\
\text { manufacturer, builder, or owner) } \\
\text { could overcome many of these } \\
\text { problems. }\end{array}$ & (see record) \\
\hline cost & 8.16 & $\begin{array}{l}\text { There was less regulation (in the } \\
\text { 40s). }\end{array}$ & $\begin{array}{l}\text { The combination of affordability and other } \\
\text { characteristics provides a historical precedent from } \\
\text { the period immediately following World War II. }\end{array}$ \\
\hline cost & 8.17 & $\begin{array}{l}\text { Current attitudes toward resisting } \\
\text { change are relatively rigid. }\end{array}$ & $\begin{array}{l}\text { Also, to add another perspective, this construction } \\
\text { happened after the Great Depression, which saw } \\
\text { widespread price deflation. Therefore, cheaper } \\
\text { homes were not seen as a threat. }\end{array}$ \\
\hline & 8.172 & (see notes) & $\begin{array}{l}\text { Now, homeowners' associations object to changes } \\
\text { (on the basis of change to the character of the } \\
\text { community). Post-World War II history was unusual. }\end{array}$ \\
\hline cost & 8.25 & $\begin{array}{l}\text { In-fill development runs into } \\
\text { titling/subdivision problems; do not } \\
\text { understand suggested spur to } \\
\text { innovation. }\end{array}$ & $\begin{array}{l}\text { The choice is between new homes or rehabbing old } \\
\text { homes. Infill development is made difficult by land } \\
\text { use requirements. Regarding a previous comment, I } \\
\text { am not sure how rehabilitation is connected to the } \\
\text { introduction of new technologies). }\end{array}$ \\
\hline cost & 8.301 & (see notes) & $\begin{array}{l}\text { There is little interest in having land available for more } \\
\text { new housing at this time: in NJ, } 63 \% \text { of the public } \\
\text { voted to restrict } 50 \% \text { of orphan land then designated } \\
\text { for housing development out of use. The voted } \\
\text { against new housing. The yearly charge/cost of a }\end{array}$ \\
\hline
\end{tabular}




\begin{tabular}{|c|c|c|c|}
\hline 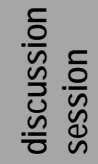 & 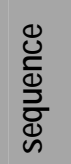 & 'flip chart' record & NIST notes \\
\hline & & & $\begin{array}{l}\text { house is base on: } \\
\text { - Inventory value } \\
\text { - Maintenance costs } \\
\text { - Operating costs } \\
\text { Durability (currently no rating scale/little } \\
\text { data) } \\
\text { Durability and maintenance values are closely related. }\end{array}$ \\
\hline cost & 8.34 & (see notes) & $\begin{array}{l}\text { California addressed this question in } 1980 \text { by allowing } \\
\text { manufactured units in existing areas as long as the } \\
\text { look and character of the area was preserved. }\end{array}$ \\
\hline cost & 8.36 & (see notes) & There was a cost. \\
\hline
\end{tabular}

- Delivery system: (for housing and housing products)

\begin{tabular}{|c|c|c|c|}
\hline 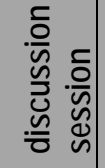 & 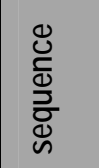 & 'flip chart' record & NIST notes \\
\hline push & 2.11 & Some choices may be allowed. & $\begin{array}{l}\text { All builders want to be seen as custom. But in truth, } \\
\text { most builders will only offer limited choices. But these } \\
\text { choices tend to be about cosmetic attributes, such as } \\
\text { counter tops, rather than long-run, performance- } \\
\text { enhancing elements. }\end{array}$ \\
\hline risk & 5.14 & $\begin{array}{l}\text { Group is making a great argument } \\
\text { for manufactured housing/modular } \\
\text { housing. Low-pitched roofs are a } \\
\text { response to bridge height } \\
\text { restrictions (not pretty). }\end{array}$ & $\begin{array}{l}\text { This is an argument for manufactured housing. The } \\
\text { current perspective, however, is that onsite-assembled } \\
\text { housing is superior to pre-manufactured housing } \\
\text { elements. }\end{array}$ \\
\hline risk & 5.153 & (see notes) & $\begin{array}{l}\text { There is a need to expand the testing that is in place, } \\
\text { to streamline it. }\end{array}$ \\
\hline risk & 5.19 & $\begin{array}{l}\text { Prevent innovation adoption-target } \\
\text { of marketing/product purchase; } \\
\text { decision is 'no' if equal or greater } \\
\text { cost than what it is substituting for. }\end{array}$ & $\begin{array}{l}\text { Manufacturers sometimes target the wrong agent to } \\
\text { promote a product, that is, the purchasing agent, who } \\
\text { is taught to say no if the product costs more. It should } \\
\text { be the sales and marketing folks. }\end{array}$ \\
\hline risk & 5.192 & $\begin{array}{l}\text { Retailer may not want to stock (e.g. } \\
\text { additional sked space/sku's). New } \\
\text { technology often must completely } \\
\text { replace something already out } \\
\text { there. Tough sell. }\end{array}$ & $\begin{array}{l}\text { Also, a new product is another SKU number that the } \\
\text { retailer will have to keep track of for inventory. } \\
\text { Retailers resist change. }\end{array}$ \\
\hline cost & 8.01 & $\begin{array}{l}\text { Mandated innovation is } \\
\text { disproportionately a burden to low- } \\
\text { income buyers of housing. } \\
\text { Owners are interested in restricting } \\
\text { supply to protect the value of their } \\
\text { assets. } \\
\text { Politicians have an interest in } \\
\text { protecting asset value as well. } \\
\text { Should builders bear some of the }\end{array}$ & $\begin{array}{l}\text { - To an extent this obvious: the manufacturer will } \\
\text { end up paying for innovations. } \\
\text { - } \quad \text { It is easy to pass costs on to the first time house } \\
\text { buyer. } \\
\text { - People that own existing homes are possible } \\
\text { bearers of cost: it is in their interest to restrict the } \\
\text { supply in order to increase house value. } \\
\text { - Homebuilders are in a position to pass on to } \\
\text { consumer, except if consumers show no interest }\end{array}$ \\
\hline
\end{tabular}




\begin{tabular}{|c|c|c|c|}
\hline 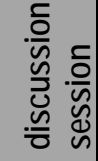 & 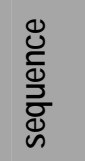 & 'flip chart' record & NIST notes \\
\hline & & $\begin{array}{l}\text { cost, especially for innovations that } \\
\text { the buyer is not expressly interested } \\
\text { in? } \\
\text { Concentration in the building } \\
\text { industry (SF) is already occurring; } \\
\text { do we want it to accelerate? Would } \\
\text { that promote innovation (in a less } \\
\text { competitive marketplace)? Medium- } \\
\text { sized builders are a key segment of } \\
\text { homebuilders. } \\
\text { If considering a new delivery } \\
\text { system, how would it be regulated? } \\
\text { Would local regulators necessarily } \\
\text { lose control of the process? }\end{array}$ & $\begin{array}{l}\text { in the specific innovation. } \\
\text { - If we have a market with fewer large innovators, } \\
\text { do more costs get passed on to the consumer? } \\
\text { - Is there a viable place for the medium sized } \\
\text { producer? } \\
\text { - New delivery system: do local officials lose control } \\
\text { of the system? }\end{array}$ \\
\hline cost & 8.09 & $\begin{array}{l}\text { Question of who pays remains; } \\
\text { what of the suggested changes } \\
\text { would be paid by actors? By feds? }\end{array}$ & $\begin{array}{l}\text { This goes to externalities. To internalize these, need } \\
\text { the Federal government. The Federal government is } \\
\text { the appropriate bearer for the cost of such innovations } \\
\text { that increase the general social welfare. Education } \\
\text { and training address a different market failure. }\end{array}$ \\
\hline cost & 8.19 & $\begin{array}{l}\text { No individual will put up with any } \\
\text { cost to change product delivery. } \\
\text { Who will pay? A demo project could } \\
\text { prove concept. Entrepreneur will } \\
\text { then move to rental side because } \\
\text { lender will not incent builder directly. } \\
\text { ROI could be changed by } 5 \% \text { by } \\
\text { assuming risk of utility/energy costs. }\end{array}$ & $\begin{array}{l}\text { Relying on rehabilitated housing would take too much } \\
\text { time. Areas like Johnstown and Schenectady, NY } \\
\text { were built during the } 1920 \text { s and } 1930 \text { s. There is now a } \\
\text { lot of vacancy there. The problem with these areas is } \\
\text { that they are past desirability, and that is a barrier to } \\
\text { rehabilitation. Regarding an earlier comment about the } \\
\text { cost of infrastructure, I am now demonstrating and } \\
\text { developing a project using renewable energy. Some } \\
\text { people can find ways of capturing economic rents. I } \\
\text { make an } 18 \% \text { return on investment (ROI), five } \\
\text { percentage points higher than I would have, by } \\
\text { capturing the savings. Some people do not even make } \\
5 \% \text { ROI. }\end{array}$ \\
\hline
\end{tabular}

- Market: supply-chain, builder, homebuyer, investor [mar]

\begin{tabular}{|c|c|c|c|}
\hline 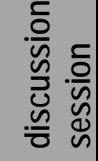 & 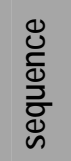 & 'flip chart' record & NIST notes \\
\hline ben & 1.14 & $\begin{array}{l}\text { Consumer does not want durability, } \\
\text { consumer wants upgraded carpet } \\
\text { - Buyer is buying a complete } \\
\text { product package } \\
\text { - Builder has difficulty in } \\
\text { accommodating 'menu' of } \\
\text { product choices (especially for } \\
\text { spec building) } \\
\text { - Buyer expects minimum level } \\
\text { of durability }\end{array}$ & $\begin{array}{l}\text { The homeowner has limited choices in a new home } \\
\text { unless they have a custom home built. Most people do } \\
\text { not have the understanding to make choices. Except } \\
\text { for custom homes, the builder makes decisions about } \\
\text { the components of the home. Builders mass produce, } \\
\text { and do not want to give choices to buyers. In any } \\
\text { case, buyers care about visible quality, such as of } \\
\text { cabinets and carpeting, not the durability of structure. } \\
\text { Most people do not have the understanding to make } \\
\text { choices. NAHB are mainly custom builders. Most }\end{array}$ \\
\hline
\end{tabular}




\begin{tabular}{|c|c|c|c|}
\hline 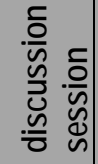 & 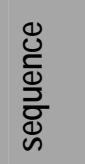 & 'flip chart' record & NIST notes \\
\hline & & & $\begin{array}{l}\text { subdivisions are not usually custom built. Need to } \\
\text { provide better information to homebuyers about the } \\
\text { importance of durability. }\end{array}$ \\
\hline ben & 1.28 & $\begin{array}{l}\text { Why would builder be interested in } \\
\text { putting in new stuff? } \\
\text { Homeowners are at risk, should } \\
\text { they also be "accountable"? }\end{array}$ & $\begin{array}{l}\text { There is resistance to innovation, including among } \\
\text { builders and renovators. Homeowners need to be held } \\
\text { accountable for their maintenance actions and } \\
\text { decisions. They need to clean gutters and maintain } \\
\text { the home, not just components. Homeowner } \\
\text { responsibility would be enhanced with a durability } \\
\text { rating because this responsibility would be rewarded } \\
\text { by increases in the durability rating, and therefore the } \\
\text { market value. We need flexibility to change. What is } \\
\text { attractive today may not be attractive tomorrow. Why } \\
\text { would the builder want to put something in? The } \\
\text { homeowner has a role in durability and needs } \\
\text { knowledge and information about it. }\end{array}$ \\
\hline push & 2.044 & (see notes) & $\begin{array}{l}\text { Realtors only care about square footage and street } \\
\text { address. People will pay for self-cleaning (stain- } \\
\text { resistant) carpets, but energy efficient renovations did } \\
\text { not pay back. }\end{array}$ \\
\hline
\end{tabular}

- Metric: $1^{\text {st }}$, annual, life-cycle, time-horizon, units-of-measurement, uncertainty, market signal, rating scale

\begin{tabular}{|c|c|c|c|}
\hline 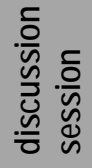 & 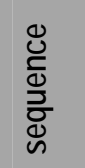 & 'flip chart' record & NIST notes \\
\hline ben & 1.08 & $\begin{array}{l}\text { As a builder, trying to shift buyer } \\
\text { emphasis from } 1 \text { st cost to life cycle } \\
\text { costs } \\
\text { NIST/HUD/regulators need to look } \\
\text { at incentives to emphasize LCC }\end{array}$ & $\begin{array}{l}\text { Need to focus on life-cycle costs. Need incentives to } \\
\text { shift rom first costs to LCC. Housing is not a free } \\
\text { market. It is defined by policy, zoning, codes, etc. } \\
\text { Need to establish a baseline for durability instead of } \\
\text { focusing on first cost. Need incentives to create better } \\
\text { housing stock rather than the status quo of more } \\
\text { housing stock. Better housing stock implies lower } \\
\text { LCC. }\end{array}$ \\
\hline ben & 1.13 & $\begin{array}{l}\text { Consider concept of 'durability } \\
\text { rating' system/policy } \\
\text { - Single number, 0-100 } \\
\text { - Market compensation of rating } \\
\text { (higher resale for higher rating) }\end{array}$ & $\begin{array}{l}\text { In a previous contract with the U.S. Forest Service, a } \\
\text { durability rating system was discussed. A policy could } \\
\text { be done by the insurance company. Every house } \\
\text { would get a number. A house rated } 80 \text { would last } \\
\text { longer than a house rated } 60 \text {. A rating of } 45 \text { would be } \\
\text { low. A house rated } 60 \text { could move up to a } 68 \text { if an } \\
\text { improvement were made to its durability. What rating } \\
\text { would be acceptable to you? Durability rating will } \\
\text { focus homeowners on looking at LCC. Homebuyers } \\
\text { are more focused on the layout of the home. To be } \\
\text { effective, the rating must mean something to the } \\
\text { consumer. Policy could play a role here, as could } \\
\text { lenders, insurers, and code inspectors. The idea is }\end{array}$ \\
\hline
\end{tabular}




\begin{tabular}{|c|c|c|c|}
\hline 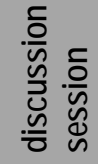 & 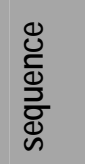 & 'flip chart' record & NIST notes \\
\hline & & & $\begin{array}{l}\text { consenting to durability rather than incenting to first } \\
\text { cost. }\end{array}$ \\
\hline ben & 1.151 & (see notes) & $\begin{array}{l}\text { The index would be difficult to develop. And it would } \\
\text { have to be credible and meaningful to the homebuyer. } \\
\text { Sometimes, the buyers do not make the "right" } \\
\text { decision, even with information. It is difficult to predict } \\
\text { this behavior. }\end{array}$ \\
\hline push & 2.13 & $\begin{array}{l}\text { As a rule-of-thumb, builder may } \\
\text { want to price at } 80 \% \text { of buyer's } \\
\text { budget, then add unforeseens, and } \\
\text { widgets that are wanted (product } \\
\text { 'pull') }\end{array}$ & $\begin{array}{l}\text { The way I deal with my clients and give them choices } \\
\text { is this: I ask my clients what their budget is, and I offer } \\
\text { them something for } 80 \% \text { of their budget. This } \\
\text { cushion allows for things like uncertainty in costs, } \\
\text { upgrades, etc. Most of the upgrades that my clients } \\
\text { opt for, however, are for widgets, such as sound } \\
\text { systems, appliances, central HVAC. }\end{array}$ \\
\hline comp & 3.02 & $\begin{array}{l}\text { Time horizons apply to builders as } \\
\text { well; builders are not opposed to } \\
\text { LCC analysis } \\
\text { Buyers are uncertain of time in } \\
\text { home, who will buy, and so use } \\
\text { varying discount rates } \\
\text { Different buyer segments behave } \\
\text { differently: } \\
\text { Higher income buyers use longer } \\
\text { time horizon } \\
\text { Lower income buyers use shorter } \\
\text { horizon (1st cost emphasis) } \\
\text { Existing owner (repeat) buyers use } \\
\text { longer horizon } \\
\text { Community wants longer horizon } \\
\text { and consideration of consequential } \\
\text { impacts } \\
\text { Builder wants to know and meet } \\
\text { customer wants (enhancing } \\
\text { reputation) } \\
\text { Product manufacturers interested in } \\
\text { long-running markets } \\
\text { Finance industry primarily } \\
\text { interested in 1st costs; operating } \\
\text { costs not factored into lending } \\
\text { decisions } \\
\text { Insurers have a longer horizon; } \\
\text { want to reduce future claims } \\
\text { State and local governments have a } \\
\text { longer horizon focusing on service } \\
\text { and utility impacts } \\
\text { Federal agencies emphasize long } \\
\text { term national policies, social costs, } \\
\text { and a social discount rate (e.g. } \\
\text { OMB will suggest discount rates to } \\
\text { lenders) } \\
\text { Affordability is now mentioned in the }\end{array}$ & $\begin{array}{l}\text { - Time horizons vary for different stakeholders. } \\
\text { - Uncertainty leads to a higher discount rate. } \\
\text { - For the homebuyer there is a tradeoff between } \\
\text { durability and aesthetics. At one time the homeowner } \\
\text { argued against life-cycle costs. The existing } \\
\text { homeowner has the same outlook as a homebuyer. } \\
\text { - High-income buyers tend to have a longer life cycle } \\
\text { horizon. Higher income people seem to have a } \\
\text { longer time horizon. } \\
\text { - A homebuilder will go by the desires of his } \\
\text { customers. How well do homebuilders perceive time } \\
\text { horizon of their customers? } \\
\text { - In finance industry, the major concern is with first } \\
\text { costs. } \\
\text { - State government is concerned with demand for } \\
\text { energy and water and have political concerns. } \\
\text { - Federal government has more of an interest in } \\
\text { viewing "society as a whole." The Federal } \\
\text { Government's view is on the people living in the room } \\
\text { and society as a whole. }\end{array}$ \\
\hline
\end{tabular}




\begin{tabular}{|c|c|c|c|}
\hline 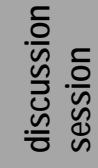 & 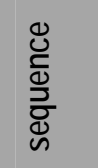 & 'flip chart' record & NIST notes \\
\hline & & $\begin{array}{lcc}\text { IRC, previously } & \text { exclusively } \\
\text { concerned with safety } & \end{array}$ & \\
\hline comp & 3.22 & $\begin{array}{l}\text { It is difficult to argue safety versus } \\
\text { economics in a public forum }\end{array}$ & $\begin{array}{l}\text { Qualitative benefit and costs come together to } \\
\text { determine the value; insurance companies are not } \\
\text { interested in adding sprinklers to all buildings because } \\
\text { of financial costs (projected costs of water damage } \\
\text { from the sprinklers in too high) }\end{array}$ \\
\hline comp & 3.251 & (see notes) & $\begin{array}{l}\text { LCC analysis is done qualitatively rather than } \\
\text { quantitatively. Small expense items, such as smoke } \\
\text { detectors, are more easily added to codes than big } \\
\text { expense items. }\end{array}$ \\
\hline comp & 3.351 & (see notes) & $\begin{array}{l}\text { Home inspectors are used only in some areas. In } \\
\text { others, people will not pay for them. For example, } \\
\text { with my mother's home in southern Virginia, the real } \\
\text { estate agent was unwilling to have a home inspector. } \\
\text { In the DC area, on the other hand, where incomes are } \\
\text { higher and people are willing to pay for it, people } \\
\text { expect it. }\end{array}$ \\
\hline cert & 4.12 & $\begin{array}{l}\$ 1800 \text { per year maintenance } \\
\text { compared to } \$ 235 \mathrm{~K} \text { price-less } \\
\text { than } 1 \% \text { per year; national "close } \\
\text { your storm windows day" at } \\
\text { Thanksgiving? }\end{array}$ & $\begin{array}{l}\text { Most deterioration of homes occurs over time and is } \\
\text { not instantaneous. But realization of deterioration is } \\
\text { sudden. For a loan-to-value (LTV) loan of } 80 \% \text {, taxes } \\
\text { and insurance are escrowed. A mortgage company } \\
\text { wants to protects its investments. A Harvard study } \\
\text { found that the average annual expenditure on home } \\
\text { maintenance is } \$ 1800 \text {. The average resale price of a } \\
\text { house is } \$ 237000 \text {. This small amount spent each } \\
\text { year to maintain what for most people is the single } \\
\text { largest repository of their personal assets is less than } \\
1 \% \text { of the value of the house. To get the housing } \\
\text { stock maintainable for } 60 \text { years, it may be necessary } \\
\text { to mandate certain requirements. There needs to be } \\
\text { something to encourage and remind homeowners } \\
\text { about maintenance, such as "National Storm Window } \\
\text { Day" on Thanksgiving, and "National Screen Day" on } \\
\text { Memorial Day. }\end{array}$ \\
\hline cert & 4.18 & $\begin{array}{l}\text { Rental property investor seeks } 1 \% \\
\text { property + improvement cash flow } \\
\text { in stable market; delay in } \\
\text { maintenance will penalize the seller; } \\
\text { how much?-subject of study? }\end{array}$ & $\begin{array}{l}\text { The investment standard is } 1 \% \text { of purchase plus } \\
\text { improvement per month in a stable or ascending } \\
\text { neighborhood. If maintenance is deferred, it penalizes } \\
\text { the seller. The market will adjust at the time of } \\
\text { transaction. }\end{array}$ \\
\hline SOC & 6.18 & $\begin{array}{l}\text { The issue is a mathematical } \\
\text { problem and not that difficult to } \\
\text { understand: value of stock } \\
\text { measured in trillions of dollars, } \\
\text { divided by the number of units, plus } \\
\text { annual cost of maintaining times } \\
\text { service life, divided by service life } \\
\text { equals annual cost of ownership. }\end{array}$ & $\begin{array}{l}\text { The incentive is to push durability by distributing first } \\
\text { cost. When R\&D comes in, it will be implemented } \\
\text { more easily. Longevity is the missing piece. There } \\
\text { are no data projecting durability or longevity of } \\
\text { housing. I propose a formula to compute the annual } \\
\text { cost of ownership of a home which falls with the } \\
\text { longevity of the home: annual cost = (initial cost + } \\
\text { maintenance + operating costs)/longevity of the home. } \\
\text { It disperses the first cost over a longer time horizon. } \\
\text { The social cost that is reduced with increase in } \\
\text { longevity is the need to rebuild " } 10 \text { year" homes every }\end{array}$ \\
\hline
\end{tabular}




\begin{tabular}{|c|c|c|c|}
\hline 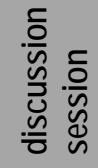 & 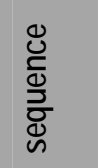 & 'flip chart' record & NIST notes \\
\hline & & & ten years. \\
\hline soc & 6.19 & $\begin{array}{l}\text { Concept makes a lot of sense } \\
\text { except for characterization as } \\
\text { "simple" problem-we do not know } \\
\text { how long housing lasts. Pricing in } \\
\text { durability may be useful, but may } \\
\text { not. }\end{array}$ & $\begin{array}{l}\text { The problem is that this would not be simple because } \\
\text { we do not know how long the housing stock lasts to } \\
\text { develop a meaningful relationship based on durability. } \\
\text { The government does not collect data on component } \\
\text { changes or demolition permits anymore. Therefore, } \\
\text { we do not know. We would have to overcome a } \\
\text { credibility problem with the consumer. }\end{array}$ \\
\hline SOC & 6.201 & (see notes) & $\begin{array}{l}\text { Without a durability rating index, a bunch of } \\
\text { disconnected people only see the first costs. There } \\
\text { needs to be some linkage between them. }\end{array}$ \\
\hline soc & 6.203 & (see notes) & $\begin{array}{l}\text { Who enforces this formula? It should be the } \\
\text { underwriting industry. }\end{array}$ \\
\hline SOC & 6.23 & (see notes) & There would be trouble monetizing these social costs. \\
\hline soc & 6.24 & (see notes) & $\begin{array}{l}\text { The formula is already done in a quasi-method. The } \\
\text { buyer gets information about the age of the roof, } \\
\text { energy costs, etc. of the prospective home. }\end{array}$ \\
\hline
\end{tabular}

- Perspective: interest, standing, constituents

\begin{tabular}{|c|c|c|c|}
\hline 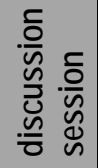 & 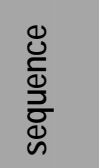 & 'flip chart' record & NIST notes \\
\hline comp & 3.11 & $\begin{array}{l}\text { Are regulators actually } \\
\text { stakeholders-do they have a stake } \\
\text { in housing longevity? }\end{array}$ & $\begin{array}{l}\text { Are regulators stakeholders? What is their interest? } \\
\text { Longevity? }\end{array}$ \\
\hline comp & 3.12 & Political stake only. & $\begin{array}{l}\text { There was one case involving the mayor of } \\
\text { Charleston, SC. He supported more stringent seismic } \\
\text { codes because he would be held accountable if he did } \\
\text { not and an earthquake occurred. The issue of liability } \\
\text { makes them stakeholders. }\end{array}$ \\
\hline comp & 3.18 & $\begin{array}{l}\text { Long term interests align regulators } \\
\text { and existing building owners }\end{array}$ & $\begin{array}{l}\text { One issue is that most voters live in existing homes, } \\
\text { not new homes. Therefore, this group drives policy } \\
\text { and regulations. }\end{array}$ \\
\hline comp & 3.258 & (see notes) & $\begin{array}{l}\text { Insurers do not take a position on home sprinklers } \\
\text { because the losses due to fire damage and those due } \\
\text { to water damage are the same. The presence of } \\
\text { sprinklers makes no difference to their underwriting } \\
\text { business. }\end{array}$ \\
\hline cert & 4.271 & (see notes) & $\begin{array}{l}\text { But the insurance payout must be used to rebuild the } \\
\text { damaged house, unless the insurance company takes } \\
\text { possession of the damaged property. Typically, an } \\
\text { insurance payout cannot be used to build or buy a } \\
\text { house in an entirely different location. }\end{array}$ \\
\hline SOC & 6.06 & $\begin{array}{l}\text { Goes back to question of } \\
\text { distribution of benefits-need } \\
\text { innovation not in widgets and hard } \\
\text { things, but in regulation- }\end{array}$ & $\begin{array}{l}\text { The key is the distribution of benefits, as a participant } \\
\text { suggested. The beneficiaries of rehab codes may not } \\
\text { be society. They may go to the private sector, such as } \\
\text { entrepreneurs. For example, risk takers buy low and }\end{array}$ \\
\hline
\end{tabular}




\begin{tabular}{|c|c|c|c|}
\hline 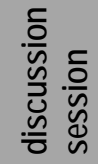 & 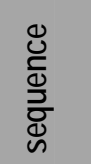 & 'flip chart' record & NIST notes \\
\hline & & $\begin{array}{l}\text { opportunities in implementation of } \\
\text { rehab codes. } \\
\text { The entrepreneur sees opportunity, } \\
\text { takes risk, should benefit-there } \\
\text { has been a } 40 \% \text { increase in } \\
\text { permits since implementation of the } \\
\text { New Jersey Rehabilitation Code } \\
\text { (primarily in vacant urban, mature } \\
\text { suburban, and decaying rural } \\
\text { properties) }\end{array}$ & $\begin{array}{l}\text { sell at higher market value. There are three places } \\
\text { where older buildings are found: urban, suburban, and } \\
\text { rural. This has happened with change in the New } \\
\text { Jersey Rehabilitation Code, because barriers were } \\
\text { removed and the regulatory system changed to allow } \\
\text { these innovations. }\end{array}$ \\
\hline SOC & 6.191 & (see notes) & $\begin{array}{l}\text { The stakeholder has a stake in making the component } \\
\text { last. }\end{array}$ \\
\hline SOC & 6.212 & (see notes) & $\begin{array}{l}\text { Even with an index, the consumer may still ignore it. If } \\
\text { this happened, it would prompt regulation. }\end{array}$ \\
\hline cost & 8.11 & $\begin{array}{l}\text { Current federal policy asserts that } \\
\text { "ownership improves housing". }\end{array}$ & $\begin{array}{l}\text { The benefit of home ownership is the long-run stake in } \\
\text { the asset. }\end{array}$ \\
\hline
\end{tabular}

- Product: development, test/evaluation, distribution, sale

\begin{tabular}{|c|c|c|c|}
\hline 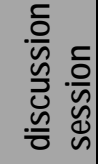 & 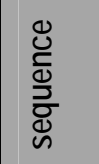 & 'flip chart' record & NIST notes \\
\hline ben & 1.11 & $\begin{array}{l}\text { Too many components/complex } \\
\text { product }\end{array}$ & $\begin{array}{l}\text { Making all these choices available would be costly for } \\
\text { the builder. }\end{array}$ \\
\hline cert & 4.21 & $\begin{array}{l}\text { Storm shutters useless if not } \\
\text { deployed. }\end{array}$ & $\begin{array}{l}\text { Hurricane shutters are only effective if someone closes } \\
\text { them before the storm. }\end{array}$ \\
\hline risk & 5.133 & (see notes) & $\begin{array}{l}\text { Testing is costly. A builder with just a few lots cannot } \\
\text { spread the costs among many units. }\end{array}$ \\
\hline risk & 5.213 & (see notes) & $\begin{array}{l}\text { Homes are more heterogeneous than cars. This } \\
\text { makes recall more difficult. }\end{array}$ \\
\hline cost & 8.29 & $\begin{array}{l}\text { Market is responding by seeking } \\
\text { opportunities for future change (e.g. } \\
\text { blocking for grab rails in baths). }\end{array}$ & $\begin{array}{l}\text { Is it possible to look forward to rehabbing current } \\
\text { housing in approximately } 20 \text { years? Would a viable } \\
\text { new delivery system be movable walls and developing } \\
\text { housing today with "exchangeable" rooms? The } \\
\text { market is addressing the question of flexibility, but not } \\
\text { on that scale. Some of the things being done now are } \\
\text { to, instead of installing grab bars in the tub ahead of } \\
\text { time, putting blocking in the wall so that they can } \\
\text { receive bars when they do become needed when the } \\
\text { homeowner gets older. }\end{array}$ \\
\hline
\end{tabular}

- Segmentation: MF/SF, new/existing, low-income/high-income 


\begin{tabular}{|c|c|c|c|}
\hline 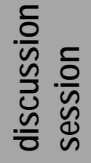 & 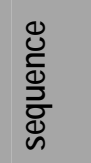 & 'flip chart' record & NIST notes \\
\hline comp & 3.031 & (see notes) & $\begin{array}{l}\text { The share of condos is } 20 \% \text {. Tax credit housing is } \\
33 \% \text {. }\end{array}$ \\
\hline cert & 4.102 & (see notes) & $\begin{array}{l}\text { Multi-family housing is different because of liability, } \\
\text { insurance, and the presence of dedicated } \\
\text { maintenance personnel. }\end{array}$ \\
\hline cost & 8.22 & $\begin{array}{l}\text { We see indications of marketplace } \\
\text { changes, but cannot yet confirm. }\end{array}$ & \\
\hline
\end{tabular}

- Value: cost, price, benefit [val]

\begin{tabular}{|c|c|c|c|}
\hline 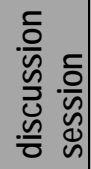 & 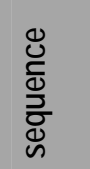 & 'flip chart' record & NIST notes \\
\hline ben & 1.101 & (see notes) & $\begin{array}{l}\text { The extent this is true depends on whether use of } \\
\text { more durable components is reflected in resale price of } \\
\text { the home. }\end{array}$ \\
\hline ben & 1.21 & $\begin{array}{l}\text { Appraised value is a blunt } \\
\text { instrument and should be more } \\
\text { sensitive. }\end{array}$ & (see record) \\
\hline push & 2.02 & $\begin{array}{l}\text { Must have a benefit to sell to } \\
\text { customer (builder typically) } \\
\text { Cannot trade off performance from } \\
\text { one system to another } \\
\text { Must create value for builder or } \\
\text { homeowner }\end{array}$ & $\begin{array}{l}\text { Agree that innovation benefits cannot be "pushed" on } \\
\text { the consumer. It is necessary to fill a place for } \\
\text { demand. "Push" is a mistake. The adoption of OSB } \\
\text { (oriented strand board) and I-joists, for example, are } \\
\text { done through the builder, by providing lower } \\
\text { installation costs, better performance, more durability, } \\
\text { other cost benefits. Innovations must provide some } \\
\text { value to the homebuilder and homeowner. Trade-offs } \\
\text { are possible only in energy performance codes. }\end{array}$ \\
\hline push & 2.04 & $\begin{array}{l}\text { Must have some sought after } \\
\text { benefit for consumer (builder) }\end{array}$ & (see record) \\
\hline push & 2.06 & $\begin{array}{l}\text { Case study: warm climate retrofit of } \\
\text { tract home c.' } 85 \text {; cut energy costs } \\
\text { by } 40 \% \text {, spent } 30 \% \text { extra, got } \\
\text { same price as next door on resale. }\end{array}$ & $\begin{array}{l}\text { Realtors only care about square footage and street } \\
\text { address. People will pay for self-cleaning carpet, not } \\
\text { greater energy efficiency. }\end{array}$ \\
\hline SOC & 6.16 & $\begin{array}{l}\text { Question remains how to value a } \\
\text { parameter in order to have a basis } \\
\text { to set a fee-the consumer views } \\
\text { the product (housing) as a durable } \\
\text { asset, internalizing ALL perceived } \\
\text { costs. }\end{array}$ & $\begin{array}{l}\text { This obsolescence only applies to regulations. With } \\
\text { incentives, people will adapt. How do you assign } \\
\text { value to these? }\end{array}$ \\
\hline
\end{tabular}

\section{Building Product Manufacturers}

- Attribute: affordability, durability, safety, etc. (flexibility, substitutability, customizability) 


\begin{tabular}{|c|c|c|c|}
\hline 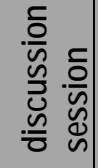 & 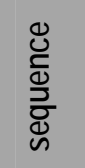 & 'flip chart' record & NIST notes \\
\hline push & 2.31 & (see notes) & $\begin{array}{l}\text { We spend a lot on market research. We have to do } \\
\text { multiple studies and take different approaches. Market } \\
\text { research is a very creative and interpretive business } \\
\text { because most people do not know what they want. }\end{array}$ \\
\hline reg & 7.08 & $\begin{array}{l}\text { First paragraph of IRC gives } \\
\text { opportunity for flexibility in } \\
\text { performance compliance with the } \\
\text { code }\end{array}$ & $\begin{array}{l}\text { Chapter } 1 \text { of the code, titled "Alternative Methods," of } \\
\text { the Evaluation Service, is most encouraging of } \\
\text { innovation. Changes in code represent a dislocation of } \\
\text { the system, which spurs innovation. There is an } \\
\text { analogy in chemistry: need to scratch a surface in } \\
\text { order for crystals to form. }\end{array}$ \\
\hline
\end{tabular}

- Barrier/Incentive: (to market acceptance)

\begin{tabular}{|c|c|c|c|}
\hline 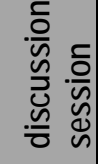 & 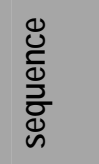 & 'flip chart' record & NIST notes \\
\hline push & 2.101 & (see notes) & Safety and protection are automatic pulls. \\
\hline risk & 5.232 & (see notes) & $\begin{array}{l}\text { There is no effective recall system for homes. This } \\
\text { makes the issue of trying to implement new } \\
\text { innovations more difficult. }\end{array}$ \\
\hline reg & 7.06 & $\begin{array}{l}\text { Regulation typically does not } \\
\text { promote or discourage change. }\end{array}$ & $\begin{array}{l}\text { It is doubtful that there would be data on this. I am not } \\
\text { sure if the regulatory system encourages or } \\
\text { discourages innovation. Sometimes, you have to know } \\
\text { how to develop "around the code." Regulation may } \\
\text { pose a barrier to adoption, but not to innovation. } \\
\text { Sometimes, codes encourage innovation if the code } \\
\text { becomes more restrictive. Manufacturers then need to } \\
\text { innovate to satisfy those restrictions. Take carbon } \\
\text { monoxide detectors, smoke alarms, energy codes, etc. }\end{array}$ \\
\hline reg & 7.091 & (see notes) & $\begin{array}{l}\text { The evaluation services, as they stand today, do not } \\
\text { give any insurance. A third-party, if so inclined, may } \\
\text { want to take the results of an evaluation and then } \\
\text { proceed with some insurance against failure to protect } \\
\text { "early users" }\end{array}$ \\
\hline reg & 7.15 & $\begin{array}{l}\text { We do code training as part of } \\
\text { product development process. }\end{array}$ & $\begin{array}{l}\text { There should be a continuing education and training } \\
\text { requirement for code officials. My company includes } \\
\text { training costs for code officials when it determines its } \\
\text { budget for developing a new product. It sees training } \\
\text { as part of the new product introduction process. }\end{array}$ \\
\hline reg & 7.24 & $\begin{array}{l}\text { Never had an NES report turned } \\
\text { down, but it takes work. }\end{array}$ & $\begin{array}{l}\text { I have never had an ESR denied by a code official. } \\
\text { Some have required them. Others have accepted the } \\
\text { data submitted to the evaluation services if an ESR is } \\
\text { pending. }\end{array}$ \\
\hline reg & 7.32 & $\begin{array}{l}\text { What can be positively said to } \\
\text { encourage acceptance } \\
\text { innovation? }\end{array}$ & $\begin{array}{l}\text { How do you change the outlook of code officials to } \\
\text { encourage more interest in acceptance of housing } \\
\text { innovation? }\end{array}$ \\
\hline
\end{tabular}


- Delivery system: (for housing and housing products)

\begin{tabular}{|c|c|c|c|}
\hline 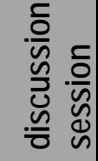 & 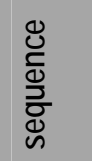 & 'flip chart' record & NIST notes \\
\hline risk & 5.191 & (see notes) & $\begin{array}{l}\text { The problem is potentially worse if there is a value } \\
\text { chain. The retailer may not want to take a risk on } \\
\text { stocking an item if it does not know whether the } \\
\text { subcontractor will want it. }\end{array}$ \\
\hline $\operatorname{cost}$ & 8.02 & $\begin{array}{l}\text { Development costs will get passed } \\
\text { to the consumer, and, even so, will } \\
\text { not be undertaken if too high. } \\
\text { If builders cannot pass on at least } \\
\text { part of the costs, they will not buy. } \\
\text { Question is not who pays, but how } \\
\text { costs are distributed. }\end{array}$ & $\begin{array}{l}\text { - Materials manufacturer will pass on increased } \\
\text { costs to the consumer. } \\
\text { - If a builder cannot pass on direct costs, they will } \\
\text { stop the innovation. } \\
\text { - Everyone along the line is going to pay some } \\
\text { share for the innovation, the question is: How is } \\
\text { the total cost divided among the different groups? } \\
\text { - Initial cost is going to be borne by the initial } \\
\text { innovator. }\end{array}$ \\
\hline cost & 8.04 & $\begin{array}{l}\text { Builder will pay the costs of the new } \\
\text { delivery process at the outset, but } \\
\text { will pass along as soon as possible. }\end{array}$ & No one entity will bear the costs of innovation. \\
\hline cost & 8.092 & (see notes) & $\begin{array}{l}\text { The construction industry does not devote as much } \\
\text { resources to R\&D. }\end{array}$ \\
\hline cost & 8.094 & (see notes) & $\begin{array}{l}\text { Everyone will see the benefits of increased home } \\
\text { ownership over time, but taxpayers will be the group } \\
\text { paying the price. }\end{array}$ \\
\hline cost & 8.18 & $\begin{array}{l}\text { Perhaps we should focus on } \\
\text { changing delivery of existing stock } \\
\text { rehabilitation. }\end{array}$ & $\begin{array}{l}\text { What will the nature of the new delivery system be? } \\
\text { Will the existing suburbs of the } 1950 \text { s be rehabilitated? } \\
\text { Will this be the new delivery system? For many } \\
\text { people, their first home is an old suburban home. Or } \\
\text { will it be an entirely new delivery system? }\end{array}$ \\
\hline
\end{tabular}

- Market: supply-chain, builder, homebuyer, investor

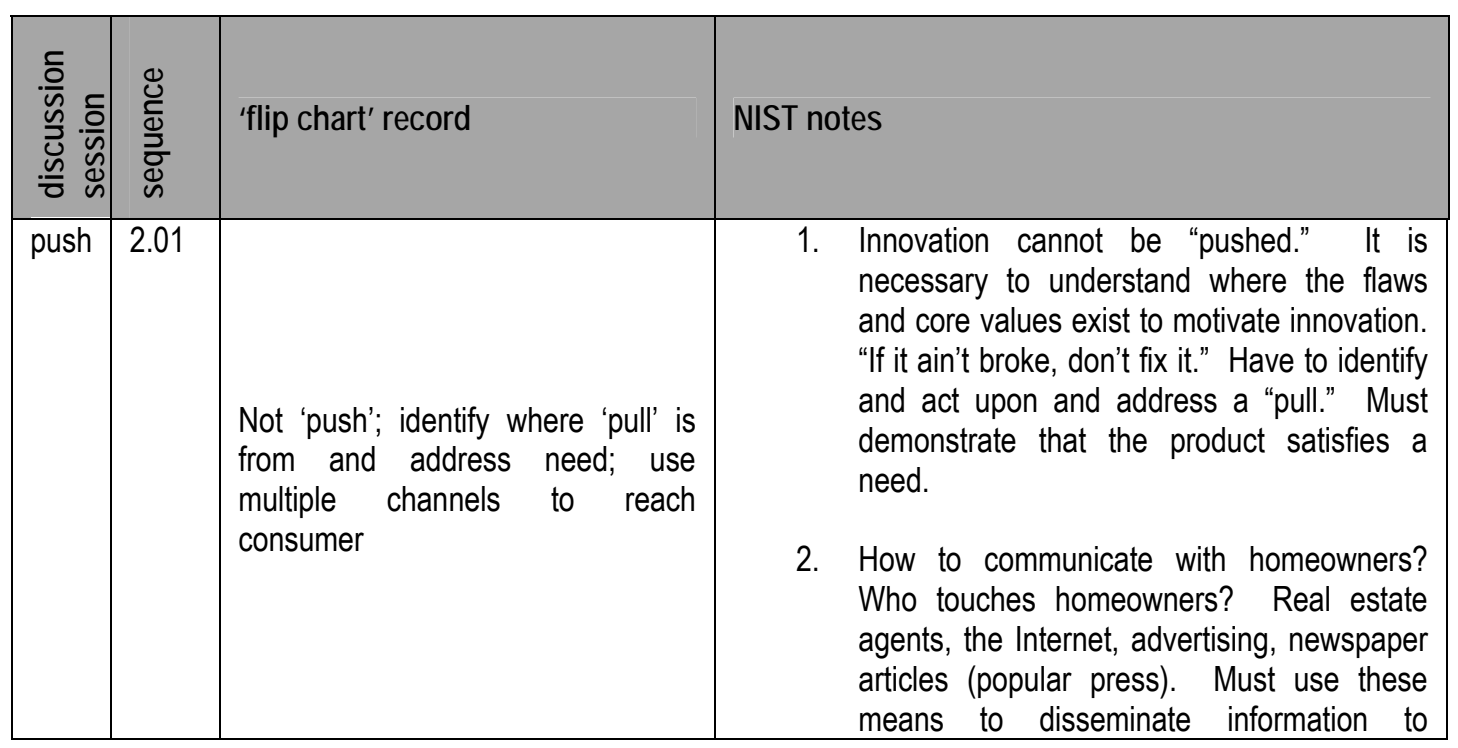




\begin{tabular}{|c|c|c|c|}
\hline 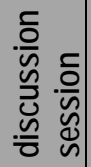 & 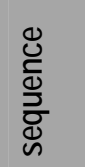 & 'flip chart' record & NIST notes \\
\hline & & & homeowners. \\
\hline push & 2.241 & (see notes) & $\begin{array}{l}\text { There is a demand for energy star products. Why has } \\
\text { Energy Star gone through an up tick recently? }\end{array}$ \\
\hline
\end{tabular}

- Metric: $1^{\text {st }}$, annual, life-cycle, time-horizon, units-of-measurement, uncertainty, market signal, rating scale

\begin{tabular}{|c|c|c|c|}
\hline 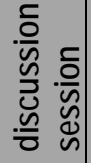 & 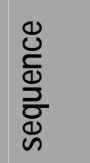 & 'flip chart' record & NIST notes \\
\hline risk & 5.04 & $\begin{array}{l}\text { We look at complete LCC, including } \\
\text { replacement cycles. }\end{array}$ & $\begin{array}{l}\text { Not in the first cost, but the cost of materials, } \\
\text { installation costs, callback costs, energy savings, and } \\
\text { durability. }\end{array}$ \\
\hline risk & 5.051 & (see notes) & $\begin{array}{l}\text { Builder customers are pretty sophisticated. Training } \\
\text { and education are also part of the package. }\end{array}$ \\
\hline
\end{tabular}

- Perspective: interest, standing, constituents

\begin{tabular}{|c|c|c|c|}
\hline 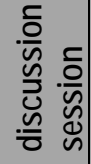 & 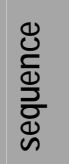 & 'flip chart' record & NIST notes \\
\hline risk & 5.27 & $\begin{array}{l}\text { Applied research is done well } \\
\text { privately; basic research is no } \\
\text { longer being done by the feds. }\end{array}$ & (see record) \\
\hline
\end{tabular}

- Product: development, test/evaluation, distribution, sale

\begin{tabular}{|c|c|c|c|}
\hline 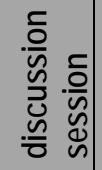 & 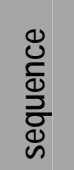 & 'flip chart' record & NIST notes \\
\hline risk & 5.02 & $\begin{array}{l}\text { How do we reduce our risk in } \\
\text { introducing new product? } \\
\text { - Evolution is manageable; } \\
\text { revolution involves unforeseen } \\
\text { issues (with greater chance of } \\
\text { failure) } \\
\text { - Assessing performance must } \\
\text { be addressed in all areas of } \\
\text { impact. } \\
\text { - ASTM standard E1825 lists } \\
\text { things to look at. } \\
\text { - Should develop installation and }\end{array}$ & $\begin{array}{l}\text { - How to mitigate risks and introduce a product } \\
\text { appropriately into the market? Dupont mitigates risk by } \\
\text { the things that they do not envision or focus on. } \\
\text { - E1825 of the ASTM Standard gives a list of what to } \\
\text { do before putting in a new system. } \\
\text { - How to prepare for those risks that you do not initially } \\
\text { envision? - One has to look at all other aspects of } \\
\text { something specific could possibly impact. } \\
\text { - Concurrently one must look at the delivery system } \\
\text { when testing a new product. The delivery system } \\
\text { needs to look at the innovation of the material } \\
\text { - It helps to look beyond first costs to LCC (costs of }\end{array}$ \\
\hline
\end{tabular}




\begin{tabular}{|c|c|c|c|}
\hline 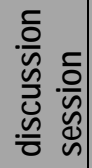 & 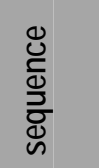 & 'flip chart' record & NIST notes \\
\hline & & $\begin{array}{l}\text { delivery system as product is } \\
\text { developed. }\end{array}$ & $\begin{array}{l}\text { owning and operating). They do look for a combination } \\
\text { of installation costs and materials costs. They try to } \\
\text { reduce the cost of owning and operating. }\end{array}$ \\
\hline risk & 5.10 & $\begin{array}{l}\text { Prescriptive standards represent } \\
\text { "the way things have been done"- } \\
\text { new product must test against } \\
\text { existing product and evaluate } \\
\text { existing product for comparison. }\end{array}$ & $\begin{array}{l}\text { Some code elements that are prescriptive are based } \\
\text { on tradition and have not been tested. To introduce a } \\
\text { new product that satisfies the same purpose, it is } \\
\text { necessary to not only test the new product, but to test } \\
\text { the existing method as well, for a comparison. This is } \\
\text { very costly. }\end{array}$ \\
\hline risk & 5.102 & (see notes) & We use it. \\
\hline risk & 5.131 & (see notes) & $\begin{array}{l}\text { "Controlled assessment" is already done, through test } \\
\text { marketing (or beta testing, for some industries). These } \\
\text { assessments are done now, but not to code, because } \\
\text { the code is just a minimum standard to market trial. } \\
\text { My company sets up early trials so that the odds of a } \\
\text { successful market trial is close to } 50 / 50 \text {. A better } \\
\text { analogy may be the auto industry as an assembler of a } \\
\text { system. Quality is outsourced to first-tier suppliers. }\end{array}$ \\
\hline risk & 5.154 & (see notes) & $\begin{array}{l}\text { This is true. The issue of time is huge. There must be } \\
\text { quality assurance, but this adds time to the process. It } \\
\text { takes } 17 \text { years to get a patent, and then the company } \\
\text { owns the technology only for a few years. Can't put } \\
\text { more time between patenting and marketing of a } \\
\text { product. Testing must be streamlined to minimize this } \\
\text { time. }\end{array}$ \\
\hline risk & 5.17 & $\begin{array}{l}\text { Performance should/will pull product } \\
\text { to higher production volume, } \\
\text { reducing cost. Many of our } \\
\text { innovations look closely at a minor } \\
\text { portion of costs (e.g. flashing for } \\
\text { windows). }\end{array}$ & $\begin{array}{l}\text { Yes, most of our products are like this. Take flashing } \\
\text { as an example. We produce a better product that is } \\
\text { highest performing. The idea is that the customer gets } \\
\text { what he or she pays for. So the product is more } \\
\text { expensive on a first cost basis. The company } \\
\text { conducts market research to value the products under } \\
\text { development. As more users come on, the cost will } \\
\text { flatten and there will be labor savings in general as } \\
\text { time goes on. }\end{array}$ \\
\hline risk & 5.172 & (see notes) & $\begin{array}{l}\text { An additional factor is that flashing does not represent } \\
\text { a high percentage of the price of an entire window } \\
\text { package. }\end{array}$ \\
\hline risk & 5.181 & (see notes) & $\begin{array}{l}\text { My company tests new products for robustness to } \\
\text { installation by brainstorming about possible installation } \\
\text { mistakes, such as picking the six worst ways to mess } \\
\text { something up and try to work with it. Not all companies } \\
\text { will do this. }\end{array}$ \\
\hline risk & 5.212 & (see notes) & $\begin{array}{l}\text { To go back to the auto analogy, one factor there is } \\
\text { ease of recall. In the building industry, there is not an } \\
\text { easy recall system. If a builder or manufacturer sent } \\
\text { out a notice, it would probably be faced with lawsuits. } \\
\text { This makes the issue of trying to implement new } \\
\text { innovations more difficult. }\end{array}$ \\
\hline reg & 7.27 & $\begin{array}{l}\text { Product must be equivalent to } \\
\text { alternative materials. }\end{array}$ & $\begin{array}{l}\text { In the "alternative methods" clause, durability is } \\
\text { included. }\end{array}$ \\
\hline
\end{tabular}


- Segmentation: MF/SF, new/existing, low-income/high-income

\begin{tabular}{|c|c|c|c|}
\hline 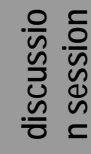 & 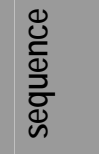 & 'flip chart' record & NIST notes \\
\hline cost & 8.221 & (see notes) & $\begin{array}{l}\text { The community where I live is on the edge of the urban } \\
\text { core, about } 5 \text { min to downtown. It is an area where } \\
\text { there are many first-time homebuyers. }\end{array}$ \\
\hline cost & 8.241 & (see notes) & $\begin{array}{l}\text { The reason I hear people want to do this is for new } \\
\text { schools. The schools in my area are not good. }\end{array}$ \\
\hline
\end{tabular}

- Value: cost, price, benefit

\begin{tabular}{|c|c|c|c|}
\hline 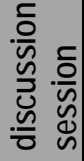 & 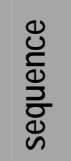 & 'flip chart' record & NIST notes \\
\hline push & 2.22 & $\begin{array}{l}\text { Goal is to find the hook for the } \\
\text { consumer and innovate to the hook }\end{array}$ & $\begin{array}{l}\text { The hook in this case is the feeling of isolation, the } \\
\text { need for community. }\end{array}$ \\
\hline soc & 6.17 & $\begin{array}{l}\text { Each consumer (including speaker) } \\
\text { uses own set of values and beliefs } \\
\text { in personal decision-making. }\end{array}$ & $\begin{array}{l}\text { Values differ from individual to individual, based on } \\
\text { their own life experiences. Heterogeneity makes } \\
\text { valuing these social costs and benefits difficult, even } \\
\text { impossible. }\end{array}$ \\
\hline
\end{tabular}

\section{Building Code Regulators}

- Attribute: affordability, durability, safety, etc. (flexibility, substitutability, customizability)

\begin{tabular}{|c|c|c|c|}
\hline 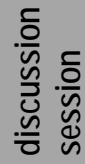 & 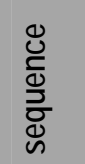 & 'flip chart' record & NIST notes \\
\hline ben & 1.20 & $\begin{array}{l}\text { Community interests must be } \\
\text { considered; long-term interests } \\
\text { matter to lenders. }\end{array}$ & $\begin{array}{l}\text { There is also a community interest in durability and } \\
\text { what causes widespread adoption of innovations. } \\
\text { Homes that do not perform become vacant. }\end{array}$ \\
\hline
\end{tabular}

- Barrier/Incentive: (to market acceptance)

\begin{tabular}{|c|c|c|c|}
\hline 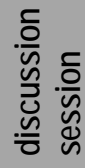 & 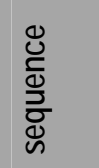 & 'flip chart' record & NIST notes \\
\hline ben & 1.221 & (see notes) & $\begin{array}{l}\text { The long term begins on day } 1 \text {. Therefore, even if they } \\
\text { ignore resale value, can still make the point about } \\
\text { buyer and owner self interest. }\end{array}$ \\
\hline
\end{tabular}




\begin{tabular}{|c|c|c|c|}
\hline 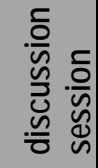 & 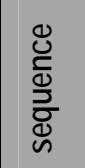 & 'flip chart' record & NIST notes \\
\hline reg & 7.07 & $\begin{array}{l}\text { New York State, prior to most } \\
\text { recent re-write, was opposite of Las } \\
\text { Vegas-said 'no' too often. } \\
\text { Performance-based requirements } \\
\text { can encourage innovation through } \\
\text { offer of options (compliance options } \\
\text { in the case of New York State). }\end{array}$ & $\begin{array}{l}\text { New York is an example. The code was too } \\
\text { prescriptive, and did not provide enough flexibility, and } \\
\text { led to higher costs to developers trying to get around } \\
\text { the regulations. Now, the provisions of the code } \\
\text { provide compliance options and are more successful. } \\
\text { Regulations cannot be created that cover everything. } \\
\text { Therefore, need a combination of prescriptive and } \\
\text { performance-based codes. }\end{array}$ \\
\hline reg & 7.35 & $\begin{array}{l}\text { Local officials need assurance-NY } \\
\text { can issue binding interpretations, } \\
\text { although not often done: it is a } \\
\text { useful tool. }\end{array}$ & $\begin{array}{l}\text { Local building officials need some certainty, for } \\
\text { someone else to be accountable, that individual } \\
\text { interpretation will not provide. They don't want the } \\
\text { decision to come back and bite them. One solution is } \\
\text { for the government to issue a binding interpretation to } \\
\text { take the interpretation out of the building officials' } \\
\text { hands. }\end{array}$ \\
\hline
\end{tabular}

- Delivery system: (for housing and housing products)

No comments.

- Market: supply-chain, builder, homebuyer, investor

No comments.

- Metric: $1^{\text {st }}$, annual, life-cycle, time-horizon, units-of-measurement, uncertainty, market signal, rating scale

\begin{tabular}{|c|c|c|c|}
\hline 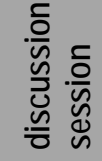 & 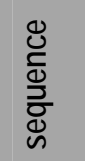 & 'flip chart' record & NIST notes \\
\hline ben & 1.16 & $\begin{array}{l}\text { Folks are working on this/these } \\
\text { ideas now. }\end{array}$ & $\begin{array}{l}\text { The Leadership in Energy and Environmental Design } \\
\text { (LEED) group already doing this, i.e., evaluating } \\
\text { products based on LCC, not first cost. }\end{array}$ \\
\hline comp & 3.17 & $\begin{array}{l}\text { State/regulator is interested in both } \\
1^{\text {st }} \text { costs and LCC }\end{array}$ & $\begin{array}{l}\text { The state/regulator is interested in both first costs and } \\
\text { LCC. }\end{array}$ \\
\hline
\end{tabular}

- Perspective: interest, standing, constituents

\begin{tabular}{|c|c|c|c|}
\hline 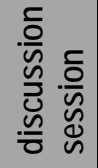 & 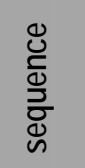 & 'flip chart' record & NIST notes \\
\hline comp & 3.13 & $\begin{array}{l}\text { Building regulators are accountable } \\
\text { to political jurisdiction. }\end{array}$ & $\begin{array}{l}\text { The key is accountability. If a restriction is loosened } \\
\text { and something happens, then the regulators will be }\end{array}$ \\
\hline
\end{tabular}




\begin{tabular}{|c|c|c|c|}
\hline 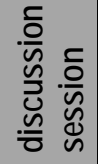 & 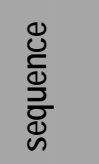 & 'flip chart' record & NIST notes \\
\hline & & & asked why the weaker standard was approved. \\
\hline comp & 3.16 & $\begin{array}{l}\text { Complicated role, but state owns a } \\
\text { lot of property (and has a stake at } \\
\text { least to that extent) }\end{array}$ & $\begin{array}{l}\text { The state of Maryland may be different in that. In } \\
\text { addition to its role as code regulator, the state of } \\
\text { Maryland owns some Maryland homes. The dual role } \\
\text { as a regulator and owner allows it to achieve some } \\
\text { objectives. }\end{array}$ \\
\hline comp & 3.30 & $\begin{array}{l}\text { Education and professionalism of } \\
\text { inspectors is important }\end{array}$ & $\begin{array}{l}\text { This is a timely issue because it will bet worse before it } \\
\text { gets better. Inspectors need to be better-trained and } \\
\text { higher quality. Labor also needs better training. }\end{array}$ \\
\hline cert & 4.28 & $\begin{array}{l}\text { There is a historic } \\
\text { model/precedence for government } \\
\text { role in property rights }\end{array}$ & $\begin{array}{l}\text { There is already precedent for government regulation } \\
\text { of home maintenance: historical homes. }\end{array}$ \\
\hline risk & 5.231 & (see notes) & $\begin{array}{l}\text { Is there a way to have groups look more objectively at } \\
\text { innovations? }\end{array}$ \\
\hline soc & 6.02 & $\begin{array}{l}\text { Complete re-write of state building } \\
\text { codes has been done-touches on } \\
\text { issues of how to value innovation in } \\
\text { housing. } \\
\text { - Agree that regulators are not a } \\
\text { direct stakeholder, in terms of } \\
\text { costs and benefits, but key } \\
\text { player/actors. } \\
\text { - State looked to balance costs } \\
\text { and benefits that 'mandated' or } \\
\text { 'incentivized'-must be done in } \\
\text { cooperation with industry and } \\
\text { society. The code was last } \\
\text { revamped in } 1984 \text { and industry } \\
\text { had grown beyond it; it } \\
\text { become an impediment to } \\
\text { building with the state. } \\
\text { Effectiveness of 'incentive' v. } \\
\text { 'regulation/mandate': government } \\
\text { must determine threshold based on } \\
\text { true and perceived risk or lose } \\
\text { public trust. } \\
\text { Public will reject increased cost until } \\
\text { they recognize benefit, then they } \\
\text { will embrace action } \\
\text { Public does not want to pay more } \\
\text { for a 'mandated' action. }\end{array}$ & $\begin{array}{l}\text { - How does society value innovation? } \\
\text { - } \quad \text { New York State recently updated/changed } \\
\text { building codes } \\
\text { - Government is not necessarily a stakeholder: role } \\
\text { is to strike a balance and express this through } \\
\text { building codes. } \\
\text { - } 1984 \text { - New York Code Council turned its back } \\
\text { for almost } 16 \text { years on the public's needs by not } \\
\text { considering new technologies. The council } \\
\text { became obsolete because of not keeping up with } \\
\text { trends. Government and society must work } \\
\text { together. } \\
\text { - Incentives vs. regulations: if government } \\
\text { regulates without input, they lose public trust. } \\
\text { - An incentive-based environment would give the } \\
\text { public time to place a value on technology. } \\
\text { Mandated regulations are rejected by the public } \\
\text { because they are likely to increase costs across } \\
\text { the board. }\end{array}$ \\
\hline
\end{tabular}

- Product: development, test/evaluation, distribution, sale

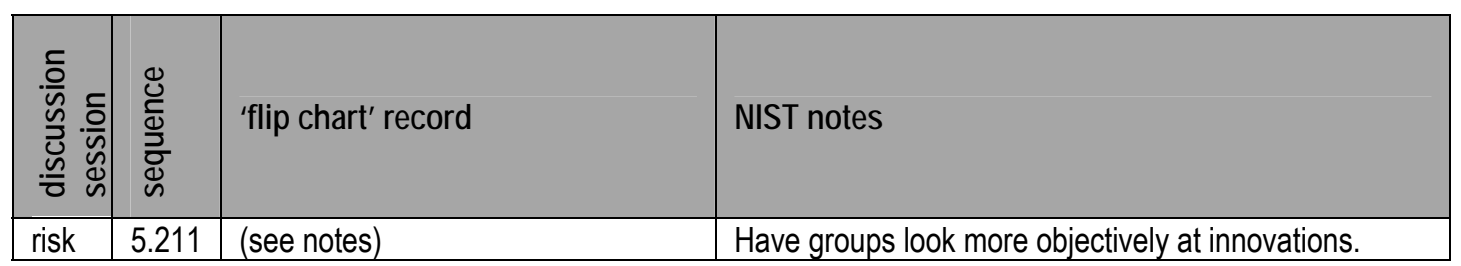


- Segmentation: MF/SF, new/existing, low-income/high-income

\begin{tabular}{|c|c|c|c|}
\hline 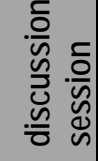 & 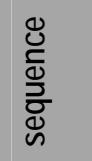 & 'flip chart' record & NIST notes \\
\hline cert & 4.22 & $\begin{array}{l}\text { From regulator perspective, recent } \\
\text { looks at contributing factors to fire } \\
\text { found vacancy a strong indicator } \\
\text { and greater frequency of vacancy in } \\
\text { poor areas }\end{array}$ & $\begin{array}{l}\text { From the perspective of regulators, they looked at fire } \\
\text { hazards when setting codes. There are factors aside } \\
\text { from the structure and maintenance that affect this } \\
\text { hazard. For example, the vacant building factor and } \\
\text { low-income factor contribute to both the probability of a } \\
\text { fire and the probability that a fire will result in a fatality. } \\
\text { These factors came into play when it came time to set } \\
\text { the codes. }\end{array}$ \\
\hline cert & 4.24 & $\begin{array}{l}\text { Commercial use next to vacancy } \\
\text { unable to get insurance; two } \\
\text { buildings away, double the cost. }\end{array}$ & $\begin{array}{l}\text { For buildings next door to vacant buildings, it is } \\
\text { impossible to get fire insurance. }\end{array}$ \\
\hline cert & 4.242 & (see notes) & This was for commercial buildings. \\
\hline
\end{tabular}

- Value: cost, price, benefit

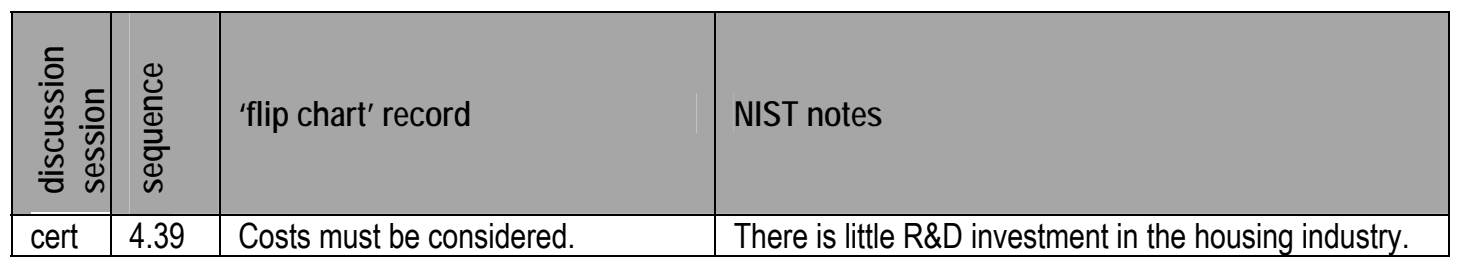

\section{Model Codes Developers}

- Attribute: affordability, durability, safety, etc. (flexibility, substitutability, customizability)

\begin{tabular}{|c|c|c|c|}
\hline 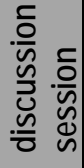 & 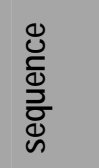 & 'flip chart' record & NIST notes \\
\hline ben & 1.25 & $\begin{array}{l}\text { Which effects/parameters should be } \\
\text { emphasized? }\end{array}$ & $\begin{array}{l}\text { Which characteristics of the house purchase are most } \\
\text { important in a homeowner's or homebuyer's judgment } \\
\text { that the home is affordable? This may reflect a matter } \\
\text { of value received for money spent, transparency of the } \\
\text { cost as part of total cost, or the individual's personal } \\
\text { involvement in the decision to accept this } \\
\text { characteristic. Which parties will benefit or be affected } \\
\text { affects whether the innovation will be available to } \\
\text { others. }\end{array}$ \\
\hline ben & 1.291 & (see notes) & $\begin{array}{l}\text { The buyers define what is affordable. Fannie and } \\
\text { Freddie are secondary players. Buyer perceptions } \\
\text { define affordability. The question is, what drives those } \\
\text { perceptions? }\end{array}$ \\
\hline ben & 1.301 & (see notes) & A house is affordable from the homeowner's \\
\hline
\end{tabular}




\begin{tabular}{|c|c|c|c|}
\hline 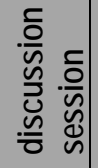 & 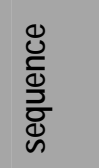 & 'flip chart' record & NIST notes \\
\hline & & & perspective. \\
\hline push & 2.09 & $\begin{array}{l}\text { Are we just left with answering the } \\
\text { question of whether production } \\
\text { process allows substitution among } \\
\text { components? }\end{array}$ & $\begin{array}{l}\text { We should focus on the third question, that of } \\
\text { tradeoffs. }\end{array}$ \\
\hline push & 2.18 & $\begin{array}{l}\text { Yes, such as impacts of distributed } \\
\text { generation, etc. Regardless of push } \\
\text { or pull, what are the effective hooks } \\
\text { for the product/innovation? Should } \\
\text { look at a menu of innovation. }\end{array}$ & $\begin{array}{l}\text { Have to identify the hooks to the consumer and } \\
\text { builder, and identify innovations. Then link the hooks } \\
\text { to the innovations. Some hooks have been power } \\
\text { reliability (loss of power is a big concern), indoor air } \\
\text { quality (IAQ) and comfort, zero or low operating costs } \\
\text { (such as low-maintenance decking), higher security, } \\
\text { etc. }\end{array}$ \\
\hline push & 2.29 & (see notes) & $\begin{array}{l}\text { We need to survey the people to see what they want. } \\
\text { Packaging matters. An example is marketing light } \\
\text { beer as "less filling" rather than "less fattening." They } \\
\text { marketed not to overweight people, who would } \\
\text { respond to the second, but to people who drank a lot, } \\
\text { who respond to the first. }\end{array}$ \\
\hline cert & 4.101 & (see notes) & $\begin{array}{l}\text { They may be in the first or the third, and may make } \\
\text { choices without thinking about maintenance and the } \\
\text { consequences of those choices. }\end{array}$ \\
\hline cert & 4.11 & $\begin{array}{l}\text { What about analogy to } \\
\text { automobiles-a defined } \\
\text { maintenance regime? } \\
\text { Why not same attributes for } \\
\text { maintaining homes and system } \\
\text { performance? }\end{array}$ & $\begin{array}{l}\text { In the case of autos, maintenance is key to } \\
\text { performance, and people do it because it is easy to } \\
\text { say yes to it, with remainders and streamlined } \\
\text { procedures. }\end{array}$ \\
\hline cert & 4.16 & $\begin{array}{l}\text { If you ignore maintenance, you are } \\
\text { playing probabilities. }\end{array}$ & People are playing the odds. \\
\hline cert & 4.29 & $\begin{array}{l}\text { Need more realistic estimate of } \\
\text { affordability }\end{array}$ & $\begin{array}{l}\text { What is needed is a notion of how affordable houses } \\
\text { are now and connect all the components of } \\
\text { affordability back to the house. }\end{array}$ \\
\hline cert & 4.332 & (see notes) & $\begin{array}{l}\text { What if the code changes being demanded were more } \\
\text { idiot proof? For example, in the case of the Rhode } \\
\text { Island nightclub fire, there was lack of adherence to } \\
\text { the code. If sprinklers, a more foolproof device, had } \\
\text { been in place, it would have made a big difference. }\end{array}$ \\
\hline risk & 5.25 & $\begin{array}{l}\text { Other industries focus on QC- } \\
\text { McDonalds. }\end{array}$ & $\begin{array}{l}\text { McDonalds is an example of an organization that has } \\
\text { managed to achieve quality control and labor } \\
\text { standardization across many countries, cultures, and } \\
\text { languages. }\end{array}$ \\
\hline soc & 6.03 & $\begin{array}{l}\text { Different take on session, based } \\
\text { primarily on an economic } \\
\text { discussion-maximizing wealth (of } \\
\text { the community) through } \\
\text { regulation/incentives that address } \\
\text { factors which are not obvious and } \\
\text { visible-"internalization of } \\
\text { externalities". }\end{array}$ & $\begin{array}{l}\text { The presence of externalities leads to the need to } \\
\text { create a pricing system more in keeping with social } \\
\text { costs (monetizing social costs) so that the externalities } \\
\text { are internalized. Under an ideal situation, society } \\
\text { makes choices, and through these choices, the best } \\
\text { pricing will occur for society as a whole. For example, } \\
\text { the price of solid waste does not include the cost to } \\
\text { society of its disposal, so a person making a purchase } \\
\text { choice does not have to consider the cost of disposal }\end{array}$ \\
\hline
\end{tabular}




\begin{tabular}{|c|c|c|c|}
\hline 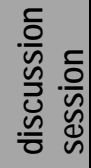 & 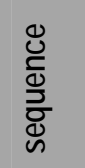 & 'flip chart' record & NIST notes \\
\hline & & & $\begin{array}{l}\text { in his decision. An alternative to incentives is } \\
\text { regulation. The downside of regulation is that it is a } \\
\text { static system, and will not create incentives to innovate } \\
\text { around the (negative) externalities. You're prohibiting } \\
\text { or directing actions. }\end{array}$ \\
\hline reg & 7.01 & $\begin{array}{l}\text { Most regulation is intended to } \\
\text { advance not affordability, but some } \\
\text { other factor, primarily safety. Many } \\
\text { regulators want to trust what they } \\
\text { know works-prescriptive } \\
\text { standards-feeling that } \\
\text { performance approaches may } \\
\text { undercut effectiveness of standards } \\
\text { and may be more difficult to } \\
\text { evaluate. Innovation may } \\
\text { exacerbate performance-based } \\
\text { evaluation concerns. In addition, } \\
\text { lack of a common language is a } \\
\text { problem-economists and policy } \\
\text { makers want express all concerns } \\
\text { in dollars. } \\
\text { Key point is that we don't need less, } \\
\text { we need better regulation-the } \\
\text { advocated approach favors } \\
\text { modeling, yielding "smart regulation } \\
\text { audited with civility" }\end{array}$ & $\begin{array}{l}\text { - Prescriptive requirements are antagonistic } \\
\text { towards new innovations. } \\
2 \text { ways of employing materials: To trust what you } \\
\text { know works is prescriptive and to prove it works is } \\
\text { performance based. } \\
\text { o performance approach: test new } \\
\text { technologies; there is no long-term field } \\
\quad \text { experience. } \\
\text { prescriptive approach; trust what you } \\
\text { know works } \\
\text { - Performance approach is difficult: does not } \\
\text { always consider reliability. If you open up } \\
\text { requirements, you may introduce unreliability. } \\
\text { If you only allow performance equivalence for } \\
\text { components, not for a whole design, you limit how } \\
\text { innovative a product you'll consider, but you also } \\
\text { limit how far from common experience and } \\
\text { comfort-zone you have to go. } \\
\text { Lack of a common language -- not everyone is } \\
\text { comfortable expressing everything in money } \\
\text { terms -- is a barrier to acceptance of performance } \\
\text { approach. } \\
\text { Economics measures costs. We need different } \\
\text { regulation. Flexibility is where we want to go. } \\
\text { We want flexibility in achieving social objectives } \\
\text { (the enforcers' role) in ways that are more } \\
\text { affordable or better in other ways. That means } \\
\text { different regulations but is not a reason to make } \\
\text { all decisions purely economic decisions. }\end{array}$ \\
\hline reg & 7.02 & $\begin{array}{l}\text { Factors must be identified and } \\
\text { explored. Should such a system be } \\
\text { a basis for regulation? What is } \\
\text { needed is a baseline level to } \\
\text { exceed. For life-safety issues, } \\
\text { codes and standards typically lag } \\
\text { technology development. If non- } \\
\text { prescriptive, there is no information } \\
\text { on which to base } \\
\text { approval/acceptance. } \\
\text { A Washington Post column } 9 \text { on } \\
\text { regulation cites } 3 \text { needs: }\end{array}$ & $\begin{array}{l}\text { - We can encourage innovation, but the manner in } \\
\text { which this will happen must be carefully } \\
\text { considered. It leads to the regulatory system } \\
\text { making decisions. Whoever is using the } \\
\text { innovation makes the decision. } \\
\text { - Establish the minimums at the state level: this } \\
\text { baseline will establish a framework for } \\
\text { considerations of new materials. } \\
\text { - Codes/standards tend to lag technological } \\
\text { developments. } \\
\text { In the absence of specific technology references } \\
\text { in the code, it is more difficult to implement the }\end{array}$ \\
\hline
\end{tabular}

\footnotetext{
${ }^{9}$ Hahn, Robert and Scott Wallsten, "Whose Life is Worth More? (And Why Is It Horrible to Ask?)," Washington Post, June 1, 2003, pp B3.
} 


\begin{tabular}{|c|c|c|c|}
\hline 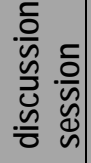 & 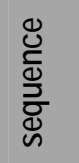 & 'flip chart' record & NIST notes \\
\hline & & $\begin{array}{l}\text { - Information based on good } \\
\text { research } \\
\text { - } \text { Ability to defend analysis tools } \\
\text { - Implementation policies that } \\
\text { encourage smart life-saving } \\
\text { analyses }\end{array}$ & technology. \\
\hline reg & 7.20 & $\begin{array}{l}\text { There are, in fact, mathematical } \\
\text { definitions for safety in the codes. }\end{array}$ & $\begin{array}{l}\text { Back to the absence of a definition of affordability: } \\
\text { There is no definition of affordability in the codes that } \\
\text { address it. This needs to be a mathematical formula. }\end{array}$ \\
\hline
\end{tabular}

\section{- Barrier/Incentive: (to market acceptance)}

\begin{tabular}{|c|c|c|c|}
\hline 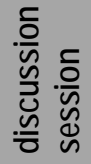 & 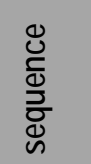 & 'flip chart' record & NIST notes \\
\hline ben & 1.22 & $\begin{array}{l}\text { Buyers are not getting information } \\
\text { related to their own interests }\end{array}$ & (see record) \\
\hline ben & 1.38 & $\begin{array}{l}\text { Suggest "dynamic constrained } \\
\text { optimization" } \\
\text { We need actions to reduce } \\
\text { constraints and/or free-up } \\
\text { constraints }\end{array}$ & $\begin{array}{l}\text { We need to set the problem up as a dynamic } \\
\text { constrained optimization. What now happens is that } \\
\text { the first cost is either the objective to be minimized, or } \\
\text { it is a constraint that is so restrictive as to make other } \\
\text { choices moot. Need something to reduce the } \\
\text { constraining effect of first cost, so that life-cycle costs } \\
\text { are the true objectives. }\end{array}$ \\
\hline comp & 3.31 & $\begin{array}{l}\text { "never enough time to do it right; } \\
\text { always enough time to do it over" }\end{array}$ & $\begin{array}{l}\text { The thinking is that "There is no time to do it right, but } \\
\text { always time to do it over." Code officials will make } \\
\text { mistakes, but we are better off with them to provide } \\
\text { the check than we would be without them. } \\
\text { The manner in which public safety is ensured by } \\
\text { having some sort of check in housing standards } \\
\text { (through codes) is important, better than having } \\
\text { nothing. }\end{array}$ \\
\hline cert & 4.141 & (see notes) & $\begin{array}{l}\text { Or draw from the auto analogy, where a warranty } \\
\text { requires adherence to a maintenance schedule. }\end{array}$ \\
\hline risk & 5.221 & (see notes) & $\begin{array}{l}\text { The earlier idea of an engineered, integrated solution } \\
\text { would get around this problem. }\end{array}$ \\
\hline SOC & 6.12 & $\begin{array}{l}\text { We need to address issues in terms } \\
\text { of economic and government } \\
\text { regulation theory }\end{array}$ & $\begin{array}{l}\text { Often the disposal fee is a flat fee and does not } \\
\text { depend on the volume of trash generated. This is a } \\
\text { justification for regulations. Regulations are used to } \\
\text { adjust and compensate for the fact that "natural } \\
\text { costing" does not automatically account for all costs. }\end{array}$ \\
\hline reg & 7.04 & $\begin{array}{l}\text { Codes must be a mix of prescriptive } \\
\text { and performance-based } \\
\text { requirements to avoid 'first-time' } \\
\text { pitfalls (redundancy/alternatives?) }\end{array}$ & $\begin{array}{l}\text { Prescriptive codes require regulators to be very } \\
\text { knowledgeable and sophisticated enough to adapt to } \\
\text { changing technology. With PBC (performance-based } \\
\text { codes), on the other hand, there is no stable ground. } \\
\text { Therefore, we need some middle ground. Australia } \\
\text { and New Zealand are examples. }\end{array}$ \\
\hline
\end{tabular}




\begin{tabular}{|c|c|c|c|}
\hline 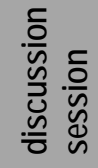 & 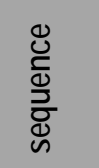 & 'flip chart' record & NIST notes \\
\hline reg & 7.16 & $\begin{array}{l}\text { We (ICC) do code official } \\
\text { certification training. }\end{array}$ & $\begin{array}{l}\text { Some states have certification and training for code } \\
\text { officials. But access and transportation are two } \\
\text { issues. }\end{array}$ \\
\hline reg & 7.31 & $\begin{array}{l}\text { Higher level issue is involved } \\
\text { here-what should regulators do } \\
\text { differently than they do now? } \\
\text { Regulators are there to provide a } \\
\text { function-that function must be } \\
\text { acceptable to those being regulated } \\
\text { in order for the system to work } \\
\text { effectively. }\end{array}$ & $\begin{array}{l}\text { Can the regulatory system be used to encourage } \\
\text { innovation? What can be done differently? Regulators } \\
\text { have a specific function. If manufacturers do not think } \\
\text { the goals are legitimate and do not respect the } \\
\text { regulators' intellectual capability, then they will not get } \\
\text { far in improving the system. }\end{array}$ \\
\hline reg & 7.312 & (see notes) & $\begin{array}{l}\text { Also, some builders resist innovation. Each actor has } \\
\text { reasons to resist innovation. }\end{array}$ \\
\hline cost & 8.031 & (see notes) & $\begin{array}{l}\text { The builder has trouble developing/justifying the use of } \\
\text { innovative resources because they will benefit all of } \\
\text { society, but they may not see all of their initial } \\
\text { investment coming back. }\end{array}$ \\
\hline cost & 8.15 & $\begin{array}{l}\text { Why did } 40 \text { s innovation occur? It } \\
\text { did not threaten existing } \\
\text { stockowners; more optimistic about } \\
\text { buyer/customer reaction to change. }\end{array}$ & $\begin{array}{l}\text { After World War II, there was a huge growth of } \\
\text { affordable housing. Why was there no objection then? } \\
\text { The reasons are: they were built in other areas, there } \\
\text { was great need, and they were not seen as } 30 \% \\
\text { cheaper because of the balance between cost and } \\
\text { attribute was not challenged. Why could this not } \\
\text { happen again? }\end{array}$ \\
\hline cost & 8.171 & (see notes) & $\begin{array}{l}\text { There is some precedent in how large-scale } \\
\text { innovations in product and delivery were adopted. }\end{array}$ \\
\hline cost & 8.175 & (see notes) & $\begin{array}{l}\text { The closer we move to a situation in which the kids } \\
\text { can't afford a home, the closer you move to the time } \\
\text { when this situation becomes intolerable. }\end{array}$ \\
\hline cost & 8.26 & $\begin{array}{l}\text { Intent is to make rehab much more } \\
\text { frequent (spurring innovation) and } \\
\text { make delivery easier. }\end{array}$ & $\begin{array}{l}\text { The concern is how it would happen. It was just an } \\
\text { unconventional idea. An important concern is to make } \\
\text { renovations easily available to the housing public. }\end{array}$ \\
\hline cost & 8.31 & $\begin{array}{l}\text { People want things for reasons that } \\
\text { are in inherent conflict. }\end{array}$ & $\begin{array}{l}\text { The vote may have been motivated by different things. } \\
\text { They did not necessarily want less housing. }\end{array}$ \\
\hline
\end{tabular}

- Delivery system: (for housing and housing products)

\begin{tabular}{|c|c|c|c|}
\hline 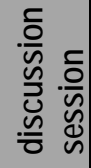 & 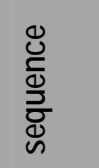 & 'flip chart' record & NIST notes \\
\hline push & 2.12 & $\begin{array}{l}\text { What about improved design, } \\
\text { equivalent performance, and } \\
\text { innovation? Is delivery system } \\
\text { capable of flexibility? }\end{array}$ & $\begin{array}{l}\text { Homebuyers want home designs to be innovative and } \\
\text { homebuilders to include innovative products without } \\
\text { increasing the price. How do we get these innovative } \\
\text { products out there? }\end{array}$ \\
\hline risk & 5.15 & $\begin{array}{l}\text { Design is an issue that lessens the } \\
\text { appeal of manufactured housing. }\end{array}$ & $\begin{array}{l}\text { The problem with manufactured housing is that the } \\
\text { designs are unattractive. }\end{array}$ \\
\hline risk & 5.152 & (see notes) & $\begin{array}{l}\text { With a traditional home, presumably affordability is not } \\
\text { the primary concern the way it is with manufactured }\end{array}$ \\
\hline
\end{tabular}




\begin{tabular}{|c|c|c|c|}
\hline 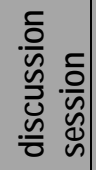 & 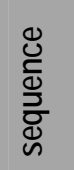 & 'flip chart' record & NIST notes \\
\hline & & & housing. \\
\hline cost & 8.08 & $\begin{array}{l}\text { Vertical integration, engineered } \\
\text { systems, modular integration are } \\
\text { strongest approaches; trades and } \\
\text { agencies should get together and } \\
\text { decide on a course of action. }\end{array}$ & $\begin{array}{l}\text { Based on the reading of the question, need to move } \\
\text { toward vertical integration, engineered solutions as a } \\
\text { participant earlier suggested. NIST and HUD need to } \\
\text { define some concepts to bring new methods of } \\
\text { delivery, such as vertical integration and } \\
\text { modularization. The builder has trouble } \\
\text { developing/justifying the use of innovative resources } \\
\text { because they will benefit all of society, but they may } \\
\text { not see all of their initial investment coming back. }\end{array}$ \\
\hline
\end{tabular}

- Market: supply-chain, builder, homebuyer, investor

\begin{tabular}{|c|c|c|c|}
\hline 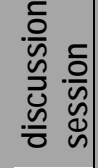 & 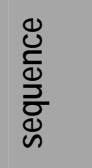 & 'flip chart' record & NIST notes \\
\hline ben & 1.09 & $\begin{array}{l}\text { Want to shift discussion from macro } \\
\text { to micro concerns: } \\
\text { - Anecdote of re-roofing, } \\
\text { question is not who benefits } \\
\text { but who receives full-effect? } \\
\text { - Homeowner does, but is given } \\
\text { no options/choices; upstream } \\
\text { decision makers decide. }\end{array}$ & $\begin{array}{l}\text { The question should not be who benefits from housing } \\
\text { innovation, but who receives its full effects. But the } \\
\text { choice of using or not using the innovation is not given } \\
\text { at time of home purchase. Choices are made for the } \\
\text { buyer "upstream," by the producers, not by the party } \\
\text { (the buyer) that receives the full effects. Homeowners } \\
\text { only choose the final packaging. But the producers } \\
\text { make the initial decisions about the use of advanced } \\
\text { technology and materials (such as for roofing). }\end{array}$ \\
\hline ben & 1.12 & $\begin{array}{l}\text { We may be forced to work upstream } \\
\text { of homeowner }\end{array}$ & $\begin{array}{l}\text { We do not want to offer unlimited choices to } \\
\text { homebuyers. But there is a need to work upstream of } \\
\text { homeowner, need to understand what part of the costs } \\
\text { and benefits that these groups see. }\end{array}$ \\
\hline ben & 1.42 & $\begin{array}{l}\text { Diffusion of innovation-later } \\
\text { adopters are less risk tolerant }\end{array}$ & $\begin{array}{l}\text { Certain types of buyers prefer innovation. These early } \\
\text { adopters accept the risks and all the other aspects of } \\
\text { being first. But this is pushing to a risk averse, more } \\
\text { conservative agenda. Innovation may not be targeted } \\
\text { to new construction, but for rehabilitation of older } \\
\text { homes. }\end{array}$ \\
\hline push & 2.042 & (see notes) & Must help the homeowners appreciate the benefits. \\
\hline
\end{tabular}

- Metric: $1^{\text {st }}$, annual, life-cycle, time-horizon, units-of-measurement, uncertainty, market signal, rating scale

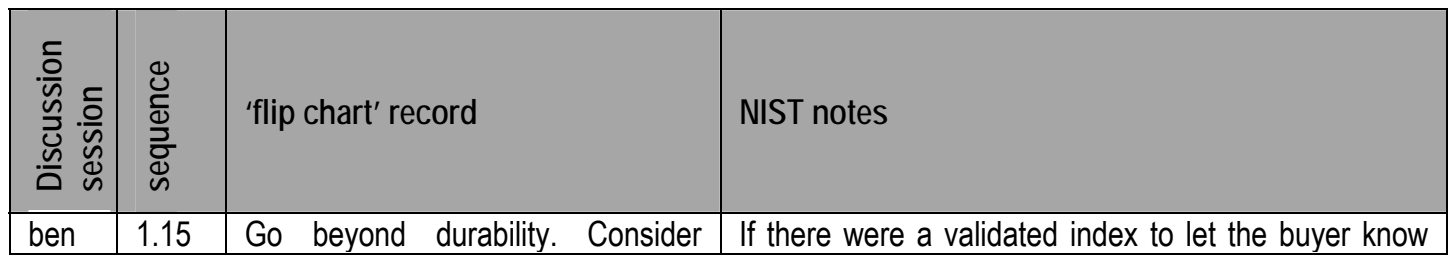




\begin{tabular}{|c|c|c|c|}
\hline 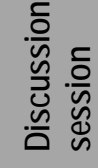 & 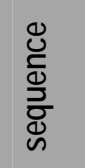 & 'flip chart' record & NIST notes \\
\hline & & $\begin{array}{l}\text { series of scales/indexes with } \\
\text { differing parameters. }\end{array}$ & $\begin{array}{l}\text { the durability and this were seen in the price, then if } \\
\text { buyers make their purchase decisions based on this } \\
\text { information, then would durability become more } \\
\text { important in the marketplace? }\end{array}$ \\
\hline ben & 1.17 & $\begin{array}{l}\text { Resignation to "the system is the } \\
\text { system" will not work }\end{array}$ & The index would be very complex. \\
\hline ben & 1.32 & $\begin{array}{l}\text { Uncertainty is the issue with } \\
\text { performance measures } \\
\text { - Want to align 'who decides' } \\
\text { with 'who decides what the } \\
\text { benefits will be' } \\
\text { - Various stakeholders/decision- } \\
\text { makers come in a different } \\
\text { points with different interests }\end{array}$ & $\begin{array}{l}\text { Regarding the earlier point about homeowner } \\
\text { responsibility, as the ceiling is lowered, the floor is } \\
\text { raised. It is important to align the benefits and } \\
\text { consequences of choices with those that make the } \\
\text { choices. In my case, labor poorly installed my } \\
\text { shingles, but I, the homeowner, had to bear the } \\
\text { consequences of that poor installation. There is no } \\
\text { way to track certain points on the development chain, } \\
\text { such as workmanship, that have a great effect on } \\
\text { value. There are some checks on this: unions, liability } \\
\text { concerns. The status quo is a sequential decision- } \\
\text { making process. When a buyer comes into the } \\
\text { process, he sees some but not all of the } \\
\text { consequences of the previous decisions. There is no } \\
\text { sword that cuts through the Gordian knots. Must } \\
\text { leverage each decision node in the process. Some } \\
\text { innovations lead to high expectations. Who } \\
\text { determines the benefit? The people receiving the } \\
\text { benefits (and costs) SHOULD be the ones making the } \\
\text { choices (but aren't always). }\end{array}$ \\
\hline push & 2.17 & $\begin{array}{l}\text { Should we be looking at 'grouped } \\
\text { benefits'? }\end{array}$ & $\begin{array}{l}\text { Another consideration is that with sprinklers, it was } \\
\text { seen that housing density could be allowed to } \\
\text { increase. }\end{array}$ \\
\hline comp & 3.20 & $\begin{array}{l}\text { Disagree; energy issue was driven } \\
\text { by economics and 'easy' LCC } \\
\text { analysis. LCC is more difficult as } \\
\text { you move to life-safety and other } \\
\text { issues }\end{array}$ & $\begin{array}{l}\text { I disagree. One counterexample is in energy codes } \\
\text { during the 1970s, which looked at payback periods } \\
\text { and assumptions about utility price escalation rates. } \\
\text { With life safety, however, an article in this Sunday's } \\
\text { Washington Post described that the value of life } \\
\text { depended on the age of the individual. Aside from } \\
\text { this, economics are not in pure safety issues, that is } \\
\text { true. }\end{array}$ \\
\hline comp & 3.24 & $\begin{array}{l}\text { SF home sprinklers cost/benefit is a } \\
\text { contemporary example: insurance } \\
\text { companies have not } \\
\text { recognized/acted on home } \\
\text { sprinklers, except in gross way that } \\
\text { smoke alarms are } \\
\text { recognized/discounted. }\end{array}$ & $\begin{array}{l}\text { Another example is in fire safety, with sprinklers and } \\
\text { sprays. There were LCC comparisons of these } \\
\text { sprinkler requirements. One issue is that insurance } \\
\text { companies do not offer a discount in premiums for } \\
\text { home sprinklers. They only offer token discounts, } \\
\text { such as for deadbolts and smoke detectors. One } \\
\text { exception of an incentive for sprinklers is for } \\
\text { community-wide sprinklers that are concentrated in a } \\
\text { locality. This incentive is due to the fact that this } \\
\text { group of houses having sprinklers makes building a } \\
\text { fire station to service that locality unnecessary. The } \\
\text { same number of houses with sprinklers scattered over } \\
\text { a wider geographic area would not have the same } \\
\text { effect. So LCC and first costs are thought about, but }\end{array}$ \\
\hline
\end{tabular}




\begin{tabular}{|c|c|c|c|}
\hline 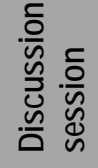 & 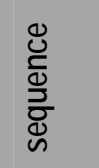 & 'flip chart' record & NIST notes \\
\hline & & & not explicitly. \\
\hline comp & 3.252 & (see notes) & $\begin{array}{l}\text { That is only two of the four boxes. What about the big } \\
\text { cost/big benefit and low cost/low benefit items? } \\
\text { Accepting low cost/high benefit and rejecting high } \\
\text { cost/low benefit changes are no-brainers. }\end{array}$ \\
\hline comp & 3.256 & (see notes) & $\begin{array}{l}\text { The NFPA has data on fatalities and injuries due to } \\
\text { fire with and without sprinklers. }\end{array}$ \\
\hline comp & 3.35 & $\begin{array}{l}\text { Home inspections are an innovation } \\
\text { in themselves }\end{array}$ & $\begin{array}{l}\text { Another innovation is the use of home inspectors. } \\
\text { They are an access point for the borrower. }\end{array}$ \\
\hline comp & 3.352 & (see notes) & $\begin{array}{l}\text { As with innovations, the practice has to disseminate } \\
\text { first. It takes hold where it is most affordable rather } \\
\text { than where it is most needed. }\end{array}$ \\
\hline cert & 4.06 & $\begin{array}{l}\text { Fire does not fit matrix well-most } \\
\text { start small and not from externality } \\
\text { but from human action } \\
\text { Most stakeholders ignore low } \\
\text { magnitude events-handling } \\
\text { quantitative info qualitatively } \\
\text { How are hazards addressed? Some } \\
\text { keep building in flood plains despite } \\
\text { regular reminders } \\
\text { Matrix works well for natural } \\
\text { hazards (eq, storms, etc.) but not } \\
\text { for high frequency events } \\
\text { ("impossible" v. "intolerable") }\end{array}$ & $\begin{array}{l}\text { Fire does not fit well into the matrix in the handout, } \\
\text { which is good for seismic risks. The matrix assumes } \\
\text { that the way to affect performance is by moderating } \\
\text { consequences, with no control over the occurrence of } \\
\text { the event. In the case of fire, however, the event is } \\
\text { usually caused by humans. Action is not only in } \\
\text { damage control, but also in prevention. Sometimes, it } \\
\text { is possible that there is no flaw in a design, but there } \\
\text { is a flaw in the process of executing or building the } \\
\text { design. Basically, there are two categories of } \\
\text { hazards: impossible, and intolerable. The day after } \\
\text { an event, it switches categories. There are also } \\
\text { assumptions about what is allowable and who would } \\
\text { prevent it. For example, there are people who do not } \\
\text { think about fire hazards. And people built in flood } \\
\text { plains until flood insurance was mandated. When life } \\
\text { events do not provide a good basis for subjective } \\
\text { probability assessment, people do not know how to } \\
\text { perceive risk. Also, if events occur that run counter to } \\
\text { their expectations, the response is distrust of the } \\
\text { source of the information about risk rather than } \\
\text { acknowledgement that the information was } \\
\text { misunderstood. }\end{array}$ \\
\hline cert & 4.071 & (see notes) & $\begin{array}{l}\text { If there were two floods in } 2 \text { years, the homeowner } \\
\text { would think they had gotten bad information or have } \\
\text { been lied to. }\end{array}$ \\
\hline cert & 4.09 & $\begin{array}{l}\text { Return to question of uncertainty- } \\
\text { low maintenance v. high } \\
\text { performance: } \\
\text { - Attracted to low uncertainty } \\
\text { because of focus on } \\
\text { maintenance costs } \\
\text { - Attracted to even high } \\
\text { uncertainty because value of } \\
\text { high performance is important } \\
\text { - Attracted to focus on first cost } \\
\text { only } \\
\text { - Ostriches }\end{array}$ & $\begin{array}{l}\text { There are two types of approaches to mitigation. The } \\
\text { first is high performance, but requires more } \\
\text { maintenance. Whether the maintenance takes place } \\
\text { is a source of uncertainty that affects the likely } \\
\text { performance of the measure. The second is } \\
\text { something that has mediocre performance, but is idiot } \\
\text { proof. } \\
\text { There are three groups of individuals: One will choose } \\
\text { mediocre performance because they want to avoid the } \\
\text { uncertainty and maintenance, even at a cost of lower } \\
\text { performance. A second will choose the high } \\
\text { performance option if the uncertainty is controllable by }\end{array}$ \\
\hline
\end{tabular}




\begin{tabular}{|c|c|c|c|}
\hline 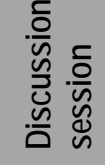 & 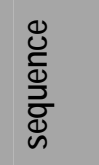 & 'flip chart' record & NIST notes \\
\hline & & & $\begin{array}{l}\text { their own actions. A third may choose the high } \\
\text { performance/high uncertainty option because they } \\
\text { care only about first cost. }\end{array}$ \\
\hline cert & 4.13 & $\begin{array}{l}\text { Frame cost/benefit against another } \\
\text { reference (e.g. value of investment) }\end{array}$ & $\begin{array}{l}\text { It would be helpful to frame the importance of } \\
\text { maintenance not in abstract terms, such as LCC, but } \\
\text { in more tangible terms, such as the number of } \\
\text { mortgage payments. Currently, maintenance is not } \\
\text { thought of as an investment choice, but as an } \\
\text { expenditure choice. }\end{array}$ \\
\hline cert & 4.171 & (see notes) & $\begin{array}{l}\text { With maintenance, there is a shift in uncertainty from } \\
\text { one that they cannot control, the realization of an } \\
\text { event, with one that they can control, maintenance. }\end{array}$ \\
\hline cert & 4.322 & (see notes) & $\begin{array}{l}\text { An event would lead to discrete changes in choices, } \\
\text { building codes, and new building technologies. } \\
\text { Experiences are flawed metrics and not rational. }\end{array}$ \\
\hline cert & 4.371 & (see notes) & $\begin{array}{l}\text { Must ask whether cost of quality improvement is } \\
\text { justified by the improvement. }\end{array}$ \\
\hline SOC & 6.15 & $\begin{array}{l}\text { Peer pressure, education, and } \\
\text { branding may be the most effective } \\
\text { options; example of 'ruffs' and 'riffs' } \\
\text { (resource utilization v. resource } \\
\text { impact, such as embodied energy } \\
\text { metric) precursor to energy codes. } \\
\text { Created huge battle between } \\
\text { electric and gas (in terms of Btus). } \\
\text { Could not drive technical decision } \\
\text { because of lack of agreement on } \\
\text { parameters. Upshot is that players } \\
\text { cannot plan on staying power of } \\
\text { analysis. }\end{array}$ & $\begin{array}{l}\text { Another incentive is branding, labeling, reputation. } \\
\text { There is an example from many years ago from } \\
\text { energy: RUF (resource utilization factor) vs. RIF } \\
\text { (resource impact factor). NIST wrote a way to } \\
\text { compare the energy performance of different } \\
\text { alternatives. The energy codes created a gas/electric } \\
\text { battle. The question arose as to whether should count } \\
\text { BTU ( } 1055 \text { joules) at the source. The RUF was } \\
\text { computed as the reciprocal of plant energy usage. } \\
\text { The RIF was needed because not all BTUs are the } \\
\text { same. It needed to be based on "embodied" energy } \\
\text { as well as all social costs and benefits, such as } \\
\text { sustainability, health care, etc. This effort fell apart } \\
\text { and died because it could not drive a technical } \\
\text { decision, and everything was valued differently. Could } \\
\text { look at this question by costs. The problem is that the } \\
\text { price does not reflect social costs. Need to pass the } \\
\text { burden of determining social costs to Department of } \\
\text { Energy. These values change and make the designs, } \\
\text { regulations, etc. obsolete. }\end{array}$ \\
\hline SOC & 6.202 & (see notes) & $\begin{array}{l}\text { Not all social costs and benefits lend themselves to } \\
\text { time-to-repair metrics. But for those that do, this index } \\
\text { would be great. }\end{array}$ \\
\hline reg & 7.13 & $\begin{array}{l}\text { Want to clarify one aspect of } \\
\text { discussion, the role of Type } 1 \text { and } \\
\text { Type } 2 \text { statistical errors in } \\
\text { evaluating the effectiveness of } \\
\text { innovation. Need to look at both } \\
\text { sides of the issues-existence of } \\
\text { both 'good' and 'bad' innovation. }\end{array}$ & $\begin{array}{l}\text { Have to worry about both "Type 1" and "Type 2" } \\
\text { statistical errors with innovations. What about } \\
\text { innovations that are accepted but fail? These are the } \\
\text { types of concerns of code officials that have to be } \\
\text { addressed to get the changes in. }\end{array}$ \\
\hline
\end{tabular}


- Perspective: interest, standing, constituents

\begin{tabular}{|c|c|c|c|}
\hline 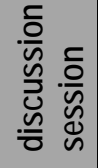 & 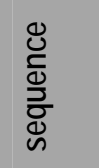 & 'flip chart' record & NIST notes \\
\hline ben & 1.33 & $\begin{array}{l}\text { Who (are stakeholders) and why: } \\
\text { - Labor unions--jobs } \\
\text { - } \quad \text { Testing labs--money, jobs, } \\
\text { uncertainty, liability } \\
\text { - Investors--money, liability } \\
\text { - } \quad \text { Political jurisdictions-- } \\
\text { constituent service }\end{array}$ & $\begin{array}{l}\text { Regarding innovations, some groups have stakes. } \\
\text { There are many people who do not want to see certain } \\
\text { innovations implemented for various reasons, such as } \\
\text { lower revenue. For labor unions, at stake are jobs, } \\
\text { compensation, and liability. For the conformity } \\
\text { assessment community (quality testing and } \\
\text { performance testing labs), the stakes are payments for } \\
\text { services and jobs. For investors and venture } \\
\text { capitalists, the stake is money. All groups are } \\
\text { incented by money, some also have liability concerns, } \\
\text { too. In addition to these groups, the stake of realtors } \\
\text { and appraisers is money. For government, it is setting } \\
\text { policy and doing right by its citizens. }\end{array}$ \\
\hline ben & 1.331 & (see notes) & $\begin{array}{l}\text { Add to the testing labs' stake uncertainty and liability } \\
\text { because of difficulty of designing a test to accurately } \\
\text { predict performance in realistic situations. }\end{array}$ \\
\hline ben & 1.332 & (see notes) & $\begin{array}{l}\text { Being first is costly. Labs will charge higher testing } \\
\text { fees to test a product that is extremely novel and is } \\
\text { dissimilar to what is already out there. }\end{array}$ \\
\hline ben & 1.333 & (see notes) & If it is willing to do the test at all. \\
\hline comp & 3.04 & $\begin{array}{l}\text { How does each stakeholder decide } \\
\text { what to consider? (Can we affect } \\
\text { the process of that decision?) } \\
\text { How are uncertainties, such as } \\
\text { hurricane, fire, etc., dealt with? How } \\
\text { are they monetized? }\end{array}$ & $\begin{array}{l}\text { Have to treat manufactured (multi-family?) homes } \\
\text { differently from single-family homes because Federal } \\
\text { regulations treat them differently. How does each } \\
\text { stakeholder determine which costs matter for their } \\
\text { decision? For occupants, it is the mortgage payment } \\
\text { or monthly rent. This is currently driven by first cost. It } \\
\text { need not be. In addition, not all maintenance is the } \\
\text { same. For example, replacing a roof is not the same } \\
\text { as fire safety or hurricane protection. Some address a } \\
\text { certain event (leaky roof) while some address } \\
\text { uncertain events (fire hazard or hurricane). Some } \\
\text { homeowners think that these uncertain events will not } \\
\text { happen. Also the risk of fatality or injury does not } \\
\text { show up in homeowner's insurance. We need to know } \\
\text { more about effective approaches in persuading } \\
\text { homeowners to factor foreseeable hazards and costs } \\
\text { into their decision-making. There are approaches with } \\
\text { at least some success with at least some audiences } \\
\text { (e.g. hurricanes in Miami). }\end{array}$ \\
\hline comp & 3.15 & $\begin{array}{l}\text { Study says regulator not a } \\
\text { stakeholder: } \\
\text { Code enforcer responsible to } \\
\text { occupant, not owner } \\
\text { Interested in LCC, but may not } \\
\text { have any leverage in the process }\end{array}$ & $\begin{array}{l}\text { We have to define "stakeholder." If it is defined as a } \\
\text { group having a financial stake in a project, then } \\
\text { regulators are not stakeholders. If it is defined as a } \\
\text { group having a stake in the outcome of a project, then } \\
\text { regulators are. In that case, must define their stake, } \\
\text { such as in LCC vs. first cost (as far as their view of } \\
\text { LCC). But some of the mechanisms to affect LCC are } \\
\text { not available to regulators. } \\
\text { A code enforcer is a stakeholder by the formal }\end{array}$ \\
\hline
\end{tabular}




\begin{tabular}{|c|c|c|c|}
\hline 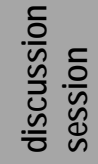 & 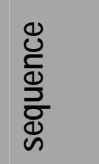 & 'flip chart' record & NIST notes \\
\hline & & & $\begin{array}{l}\text { definition of the term, but it cannot be inferred or } \\
\text { assumed that a code enforcer feels any obligation to } \\
\text { find the most acceptable way for a building project to } \\
\text { go forward. A code enforcer can live with there being } \\
\text { no building; it is not clear that any of the other } \\
\text { stakeholders can. }\end{array}$ \\
\hline comp & 3.26 & $\begin{array}{l}\text { Insurers look at data, financial } \\
\text { consequences; life safety may } \\
\text { change picture } \\
\text { Regulators come as close as any } \\
\text { stakeholder that looks at all } \\
\text { considerations }\end{array}$ & $\begin{array}{l}\text { The financial decision may be indifferent, but life } \\
\text { safety is excluded from that. Analysis with life safety } \\
\text { is an entirely different issue. The regulator is a } \\
\text { stakeholder that is closest to looking at all these costs } \\
\text { and issues in LCC. Therefore, it is not a bad place to } \\
\text { start. }\end{array}$ \\
\hline cert & 4.142 & (see notes) & $\begin{array}{l}\text { Another example is the mandatory annual safety } \\
\text { inspection for vehicles in Virginia. But autos is not a } \\
\text { good analogy because it is possible to spend more } \\
\text { maintaining a car (as a percentage of value) than on a } \\
\text { house. }\end{array}$ \\
\hline cert & 4.34 & $\begin{array}{l}\text { Codes are an imperfect but } \\
\text { valuable instrument }\end{array}$ & $\begin{array}{l}\text { Even if imperfectly enforced, codes are better than } \\
\text { nothing. }\end{array}$ \\
\hline risk & 5.28 & Worldwide problem. & $\begin{array}{l}\text { This is a global phenomenon. Almost all the fire labs } \\
\text { in the world are now privatized. }\end{array}$ \\
\hline
\end{tabular}

- Product: development, test/evaluation, distribution, sale

\begin{tabular}{|c|c|c|c|}
\hline 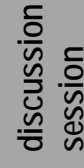 & 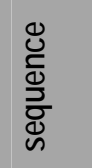 & 'flip chart' record & NIST notes \\
\hline risk & 5.07 & $\begin{array}{l}\text { Manufacturers were looking only for } \\
\text { market-pull demand for any aspect } \\
\text { of product characteristics }\end{array}$ & $\begin{array}{l}\text { There is no point in showing characteristics of products } \\
\text { that no one cares about. }\end{array}$ \\
\hline risk & 5.11 & $\begin{array}{l}\text { Armstrong testing, "no surprises", at } \\
\text { one end; other extreme, "kitchen } \\
\text { only sprinkler" } \\
\text { emphasizing/distorting kitchen risk. } \\
\text { How should evaluation be done- } \\
\text { staged, as in drug development } \\
\text { analogy? } \\
\text { Testing, more testing, then wait for } \\
\text { time before it gets out. } \\
\text { Find a way to keep good products } \\
\text { alive long enough to check } \\
\text { performance. } \\
\text { Beta testing/trial market: } \\
\text { 1. Assessment by manufacturer } \\
\text { 2. Controlled assessment by a } \\
\text { limited population } \\
\text { 3. General distribution }\end{array}$ & $\begin{array}{l}\text { Some of this discussion belongs in discussion session } \\
7 \text { later. At the fire testing college at Armstrong, the } \\
\text { mantra is "no surprises." How can the uncertainty } \\
\text { about new products be reduced to better predict } \\
\text { performance, so the good innovations will get through, } \\
\text { but the bad ones will not? How do you get a system } \\
\text { where the good innovations get out while the bad are } \\
\text { stopped quickly? There are three stages of } \\
\text { assessments: } \\
\text { 1. Manufacturer's assessment } \\
\text { 2. Controlled assessment using a limited population } \\
\text { (such as beta testing with electronics) } \\
\text { 3. Widespread, general distribution } \\
\text { This staged process is used in the pharmaceutical } \\
\text { approval process. It requires a great deal of time and } \\
\text { money, but with limited exposure to people. Some } \\
\text { disapprove of this process. }\end{array}$ \\
\hline risk & 5.112 & (see notes) & I wanted to refer to drugs as an example of a staged \\
\hline
\end{tabular}




\begin{tabular}{|c|c|c|c|}
\hline 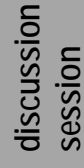 & 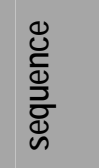 & 'flip chart' record & NIST notes \\
\hline & & & approval process. \\
\hline risk & 5.13 & $\begin{array}{l}\text { Interactions (among stakeholders) } \\
\text { are a key aspect in changing } \\
\text { product development }\end{array}$ & $\begin{array}{l}\text { To carry the drug analogy to this, the issue is drug } \\
\text { interactions. Is the product sensitive to assembly } \\
\text { issues? }\end{array}$ \\
\hline risk & 5.171 & (see notes) & $\begin{array}{l}\text { This flashing, if I am thinking about the one you are } \\
\text { talking about, involves some labor savings in } \\
\text { installation and involves more foolproof installation as } \\
\text { well. }\end{array}$ \\
\hline risk & 5.21 & $\begin{array}{l}\text { For new products: } \\
\text { - Manufacturer } \\
\text { underestimate risk } \\
\text { - Consumer will overestimate } \\
\text { risk } \\
\text { - Both will try to shift risk to } \\
\text { someone else } \\
\text { - Ultimate consumer probably } \\
\text { least able to afford risk } \\
\text { Is there a way to get better } \\
\text { information to all? }\end{array}$ & $\begin{array}{l}\text { There are three problems: } \\
\text { 1. Manufacturers champion new products and } \\
\text { underestimate the risk. } \\
\text { 2. Homeowners overestimate the risk of new products. } \\
\text { 3. All hope risk will fall on someone else, to displace } \\
\text { the risk to another party. } \\
\text { To address the question, must address all three } \\
\text { problems, not just any one. The sufferer of problem \#3 } \\
\text { will probably end up being the homeowner. Is there a } \\
\text { better way to address risk? }\end{array}$ \\
\hline risk & 5.214 & (see notes) & $\begin{array}{l}\text { Also, component manufacturers are shallow pockets. } \\
\text { They can't afford to pay for recalls. }\end{array}$ \\
\hline reg & 7.36 & $\begin{array}{l}\text { States should be careful of taking } \\
\text { on product certification functions } \\
\text { (see Florida example); it could } \\
\text { increase complexity, uncertainty, } \\
\text { and cost. }\end{array}$ & $\begin{array}{l}\text { Need to be careful with product approval and } \\
\text { conformity. There is a difference between uniformity in } \\
\text { interpretation (such as in Virginia) and conformity in } \\
\text { assessment (Florida). The latter leads to creation of a } \\
\text { new bureaucracy and another check and balance. } \\
\text { There are already enough checks and balances. }\end{array}$ \\
\hline cost & 8.123 & (see notes) & Acorns, to grow into trees. \\
\hline
\end{tabular}

- Segmentation: MF/SF, new/existing, low-income/high-income

\begin{tabular}{|c|c|c|c|}
\hline 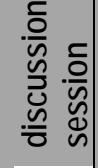 & 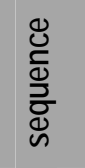 & 'flip chart' record & NIST notes \\
\hline cert & 4.23 & $\begin{array}{l}\text { Untreated wood shingles create } \\
\text { increased risk for surrounding } \\
\text { dwellings; how should it be dealt } \\
\text { with? By insurers, by codes? }\end{array}$ & $\begin{array}{l}\text { There is a special case with fire. If a homeowner uses } \\
\text { untreated wood shingles, then he increases the risk of } \\
\text { a fire to his neighbors. }\end{array}$ \\
\hline cert & 4.27 & $\begin{array}{l}\text { Getting back to vacancy } \\
\text { implications, abandonment of } \\
\text { property leads to leveraged risk for } \\
\text { others }\end{array}$ & $\begin{array}{l}\text { One person's choice to not protect can, if an event } \\
\text { occurs, affect the neighborhood. Vacant houses, for } \\
\text { instance as a result of a fire, cause rot in the } \\
\text { neighborhood. One vacant house soon becomes two } \\
\text { vacant houses, etc. }\end{array}$ \\
\hline soc & 6.08 & $\begin{array}{l}\text { This is not the topic for this session; } \\
\text { we should discuss, for example, } \\
\text { 'redevelopment' } \\
\text { development' }\end{array}$ & $\begin{array}{l}\text { We need to shift back. Infrastructure and social } \\
\text { services are examples of social costs that are truly } \\
\text { borne by the beneficiaries. }\end{array}$ \\
\hline
\end{tabular}




\begin{tabular}{|c|c|c|c|}
\hline 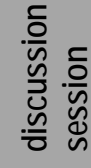 & 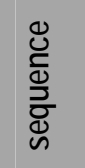 & 'flip chart' record & NIST notes \\
\hline SOC & 8.20 & $\begin{array}{l}\text { Imagine easy ways to change how } \\
\text { you use your house. Need a } \\
\text { delivery system to routinize rehab } \\
\text { and reuse. Introduce innovation } \\
\text { through rehab rather than new } \\
\text { construction. }\end{array}$ & $\begin{array}{l}\text { Back to the earlier comment about rehabilitation as an } \\
\text { alternative delivery system: Could you make renovated } \\
\text { houses a place to implement innovations? Now, there } \\
\text { is a rash of people in my neighborhood adding rooms } \\
\text { or second stories. If this were easier to do, what would } \\
\text { happen? How about rehabilitation and expanded } \\
\text { capacity as an innovative system of delivery? }\end{array}$ \\
\hline
\end{tabular}

- Value: cost, price, benefit

\begin{tabular}{|c|c|c|c|}
\hline 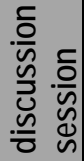 & 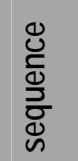 & 'flip chart' record & NIST notes \\
\hline cert & 4.40 & $\begin{array}{l}\text { No guarantee that innovation either } \\
\text { lowers costs or increases quality }\end{array}$ & $\begin{array}{l}\text { Innovation may reduce cost, but may also reduce } \\
\text { quality. All we know about an innovation is that it is } \\
\text { new (there is uncertainty). }\end{array}$ \\
\hline
\end{tabular}

\section{Buildings/Economics Researchers}

- Attribute: affordability, durability, safety, etc. (flexibility, substitutability, customizability)

\begin{tabular}{|c|c|c|c|}
\hline 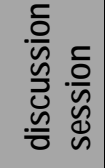 & 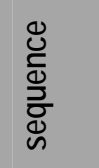 & 'flip chart' record & NIST notes \\
\hline ben & 1.202 & (see notes) & $\begin{array}{l}\text { Real estate professionals and appraisers must be } \\
\text { included because they affect the price of the house. }\end{array}$ \\
\hline ben & 1.29 & $\begin{array}{l}\text { 'Affordability' is whatever } \\
\text { FNMA/Freddie Mac say it is (PITI) }\end{array}$ & $\begin{array}{l}\text { The extent and quality of maintenance is already } \\
\text { captured in the resale value of the home. The } \\
\text { homeowner is a liable party. The starting point of the } \\
\text { affordability question is that it is based on whether } \\
\text { Fannie or Freddie says it is affordable, i.e., can you } \\
\text { qualify for the mortgage? }\end{array}$ \\
\hline push & 2.15 & $\begin{array}{l}\text { Disagree that structural system } \\
\text { cannot be changed }\end{array}$ & $\begin{array}{l}\text { It depends on the product whether it gets adopted } \\
\text { even if it is not observable to the buyer. For example, } \\
\text { engineered lumber vs. conventional lumber, or OSB } \\
\text { vs. plywood. Some of the decisions are not made by } \\
\text { the homebuyer. }\end{array}$ \\
\hline push & 2.211 & (see notes) & $\begin{array}{l}\text { Developments such as Kentlands are called the "new } \\
\text { urbanization." }\end{array}$ \\
\hline push & 2.28 & (see notes) & $\begin{array}{l}\text { The problem is what is the incentive of lenders and } \\
\text { insurance companies to do this? If the benefits go to } \\
\text { the community, then the community should provide } \\
\text { the incentives. }\end{array}$ \\
\hline
\end{tabular}




\begin{tabular}{|c|c|c|c|}
\hline 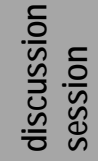 & 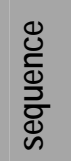 & 'flip chart' record & NIST notes \\
\hline comp & 3.05 & $\begin{array}{l}\text { Questions will be dealt with in later } \\
\text { sessions - current research is } \\
\text { looking at parameters that are/will } \\
\text { be used. }\end{array}$ & $\begin{array}{l}\text { Issue with natural hazards shows up in insurance } \\
\text { payments, not so much in mortgage payments. These } \\
\text { issues will be addressed more fully in later sessions: } \\
\text { tomorrow's session on valuing social costs and } \\
\text { benefits and this afternoon's session on low probability } \\
\text { events. }\end{array}$ \\
\hline cost & 8.30 & $\begin{array}{l}\text { Flexibility related to addressing } \\
\text { sprawl may be effective. }\end{array}$ & $\begin{array}{l}\text { This flexibility is found in commercial office space. } \\
\text { NIST North is leased, is it not? Commercial space } \\
\text { must be flexible because the tenants change and so } \\
\text { do their needs. To go back to the zoning and local } \\
\text { regulation issues, my organization sees sprawl as a } \\
\text { pejorative. The example of Montgomery County's } \\
\text { budget is unusual, and it will tighten. Everywhere, } \\
\text { local budgets are tight, and this has to be dealt with. If } \\
\text { local governments do not get involved, urban sprawl } \\
\text { will eventually force them to do so. }\end{array}$ \\
\hline
\end{tabular}

- Barrier/Incentive: (to market acceptance)

\begin{tabular}{|c|c|c|c|}
\hline 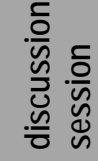 & 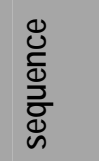 & 'flip chart' record & NIST notes \\
\hline ben & 1.24 & $\begin{array}{l}\text { Contrary evidence-energy } \\
\text { mortgage has not taken off } \\
\text { The basic question of who benefits } \\
\text { needs to be modified }\end{array}$ & $\begin{array}{l}\text { But energy-efficient mortgages have not taken off and } \\
\text { are not widely accepted, even } 15 \text { years after their } \\
\text { introduction. }\end{array}$ \\
\hline ben & 1.241 & (see notes) & The lesson to be drawn is to look at why. \\
\hline ben & 1.242 & (see notes) & $\begin{array}{l}\text { The reasons are too complex to be addressed here. } \\
\text { The questions to be asked must be, what will the } \\
\text { benefits of the innovation be and who will benefit? If } \\
\text { an innovation becomes widespread practice, what are } \\
\text { its impacts? You cannot answer the question on } \\
\text { affordability unless you know in whose mind. } \\
\text { Perception changes for the 1st time homebuyer }\end{array}$ \\
\hline ben & 1.382 & (see notes) & $\begin{array}{l}\text { The contrast between the for-profit and non-profit } \\
\text { builders is too stark. For speculative builders, the time } \\
\text { horizon is shorter. But they care about what they build } \\
\text { to the extent that they want to avoid callbacks and } \\
\text { liability. Their time horizon may be about } 5 \text { years } \\
\text { (maybe ten in California). The question is, how can } \\
\text { the time horizon of for-profit builders be extended } \\
\text { beyond these } 5 \text { years to } 10 \text { years? Right now, } \\
\text { ambulance chasers are having this effect. They are } \\
\text { forcing builders to confront durability in a way not done } \\
\text { a few years ago, and to choose "tried and true" } \\
\text { materials. The effect is for the builders to not choose } \\
\text { the cheapest products, but also not to choose the } \\
\text { most innovative products, either. }\end{array}$ \\
\hline
\end{tabular}




\begin{tabular}{|c|c|c|c|}
\hline 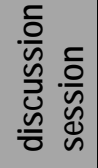 & 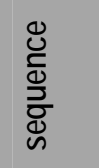 & 'flip chart' record & NIST notes \\
\hline push & 2.10 & $\begin{array}{l}\text { Consumer is responding in certain } \\
\text { areas to energy star home as a } \\
\text { marketing tool-first instance of } \\
\text { label having an impact in housing } \\
\text { markets }\end{array}$ & $\begin{array}{l}\text { Builders in some cities have had success with the } \\
\text { energy-star labeled home, especially those with } \\
\text { younger populations in the far west (granola crowd). } \\
\text { This is the first successful attempt where a } \\
\text { performance label is having an effect, even if it is only } \\
\text { to a certain segment of the population. Why was it } \\
\text { successful? }\end{array}$ \\
\hline push & 2.104 & (see notes) & No, that tradeoff cannot be done. \\
\hline push & 2.161 & (see notes) & $\begin{array}{l}\text { Or the innovation could be, as was earlier mentioned, } \\
\text { in engineered systems. }\end{array}$ \\
\hline push & 2.162 & (see notes) & $\begin{array}{l}\text { Improvements in business systems can lead to } \\
\text { improvements in cycle time. But even with big outfits, } \\
\text { there are many inefficiencies and no one seems to } \\
\text { care. }\end{array}$ \\
\hline comp & 3.07 & $\begin{array}{l}\text { Home insurance industry is not } \\
\text { responsive to efforts to get them to } \\
\text { consider incentives for durability } \\
\text { Great variation from state to state, } \\
\text { no rational relation to housing } \\
\text { quality }\end{array}$ & $\begin{array}{l}\text { The most negligent group over the last three to four } \\
\text { years has been the home insurance industry, in } \\
\text { ignoring LCC. They resist changing rates to reflect } \\
\text { construction changes. They should recognize and } \\
\text { price their product based on durability and disaster } \\
\text { resistance, but they do not. Premiums in Florida are } \\
\text { twice those in Pennsylvania. But building for safety } \\
\text { and disaster resistance does not lower the premium in } \\
\text { Florida. This is especially true now that the insurance } \\
\text { companies' stock portfolios have tanked and they are } \\
\text { more reliant on underwriting income. In response, } \\
\text { insurance companies have increased premiums. } \\
\text { Resistance to changing premiums is greatest in high } \\
\text { premium states. }\end{array}$ \\
\hline comp & 3.072 & (see notes) & $\begin{array}{l}\text { No. These companies just want to make profit. They } \\
\text { will support changes in codes without data, but when it } \\
\text { comes to talking about reducing premiums, they want } \\
\text { data. }\end{array}$ \\
\hline comp & 3.32 & $\begin{array}{l}\text { Is there a "durability mortgage"? } \\
\text { Has been announced, but what is } \\
\text { it? What is the potential for impact } \\
\text { on future value of housing } \\
\text { condition? }\end{array}$ & $\begin{array}{l}\text { The question is LCC vs. durability. I have heard that } \\
\text { Fannie is developing a durability mortgage. What is } \\
\text { it? Is it similar to the energy-efficient mortgage? What } \\
\text { does it cover? }\end{array}$ \\
\hline risk & 5.23 & $\begin{array}{l}\text { Labor problems have only gotten } \\
\text { worse over last } 40 \text { years. }\end{array}$ & $\begin{array}{l}\text { The labor problem has only gotten worse and will } \\
\text { continue to do so. }\end{array}$ \\
\hline SOC & 6.07 & $\begin{array}{l}\text { Should we remove regulatory } \\
\text { intervention? There are too many } \\
\text { gatekeepers; find other ways to } \\
\text { protect buyers, such as "builders } \\
\text { insurance"? }\end{array}$ & $\begin{array}{l}\text { The change in the regulations is key. There are too } \\
\text { many gatekeepers. We should try to remove as many } \\
\text { barriers as possible. If there is a valid program of } \\
\text { builders' insurance and consumer product safety, then } \\
\text { the regulations can be scaled back. }\end{array}$ \\
\hline soc & 6.09 & $\begin{array}{l}\text { We should be looking at incentives } \\
\text { (for solar, flood, hazard mitigation, } \\
\text { etc.) based on social benefits and } \\
\text { costs. }\end{array}$ & $\begin{array}{l}\text { There are incentives for social costs and benefits at } \\
\text { the level of individual homeowners in some areas, } \\
\text { such as for weather hazards. For example, the } \\
\text { homeowners would only be eligible for flood insurance } \\
\text { if they took certain precautions. It is also necessary to } \\
\text { focus on owner-occupied housing. }\end{array}$ \\
\hline
\end{tabular}




\begin{tabular}{|c|c|c|c|}
\hline 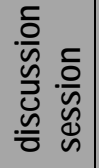 & 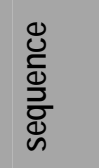 & 'flip chart' record & NIST notes \\
\hline SOC & 6.131 & (see notes) & $\begin{array}{l}\text { With the New Jersey Rehabilitation Code, reforms } \\
\text { turned out to have the same effect as removal. It } \\
\text { lightened the burden. }\end{array}$ \\
\hline soc & 6.133 & (see notes) & $\begin{array}{l}\text { It is possible to internalize externalities in many ways, } \\
\text { such as tax credits, insurance incentives. Do we want } \\
\text { to do it all? }\end{array}$ \\
\hline reg & 7.05 & $\begin{array}{l}\text { Do we have any evidence that more } \\
\text { innovation occurs under one or the } \\
\text { other scheme of regulation } \\
\text { (performance versus prescriptive } \\
\text { codes)? }\end{array}$ & $\begin{array}{l}\text { Is there any empirical evidence about the amount of } \\
\text { innovation that has occurred under prescriptive } \\
\text { regimes vs. PBC? }\end{array}$ \\
\hline reg & 7.09 & $\begin{array}{l}\text { Industry is so fragmented, no single } \\
\text { organization is large enough to } \\
\text { overcome barriers to innovation. } \\
\text { Why is housing the only industry } \\
\text { that can not/ will not benefit from } \\
\text { innovation? } \\
\text { Until risk-based insurance is } \\
\text { available, innovation will not be } \\
\text { approved/adopted. } \\
\text { We need to link comprehensive } \\
\text { evaluation to a push for risk-based } \\
\text { insurance underwriting. }\end{array}$ & $\begin{array}{l}\text { One issue is the lack of market power of any builders } \\
\text { in the housing industry. In the long run, stimulating } \\
\text { development in housing is good, because it will benefit } \\
\text { society as a whole. But the housing industry is still not } \\
\text { totally geared in this direction. The home building } \\
\text { industry is more resistant to innovation than in other } \\
\text { industries. They perceive themselves in this way. } \\
\text { They do not buy it (innovation). Why can't the home } \\
\text { building industry be more like other industries in this } \\
\text { way? Why do they not reduce the barriers to } \\
\text { innovation? The ICC Evaluation Service did not } \\
\text { perform very well before. Using these evaluation } \\
\text { services, there needed to be an insurance program for } \\
\text { innovation to bridge the gap in reliability, uncertainty, } \\
\text { risk of system failure associated with new products. } \\
\text { The missing element is an insurance program for } \\
\text { innovation. In the current situation, local enforcers will } \\
\text { be held accountable for failure. With insurance, there } \\
\text { would be a cover for the homebuilder and component } \\
\text { manufacturer to encourage innovation and adoption. }\end{array}$ \\
\hline reg & 7.092 & (see notes) & $\begin{array}{l}\text { You have to combine evaluations systems and } \\
\text { insurance in order to help increase development. }\end{array}$ \\
\hline reg & 7.11 & $\begin{array}{l}\text { Suggest that government undertake } \\
\text { research/modeling of insurance- } \\
\text { based approach to housing } \\
\text { innovation; determine appropriate } \\
\text { government roles (analogous to } \\
\text { self-amortizing mortgages); } \\
\text { determine feasibility. }\end{array}$ & $\begin{array}{l}\text { With the insurance idea, need to do the following. } \\
\text { First, do research and model what the insurance } \\
\text { would look like. Second, would the insurance industry } \\
\text { be willing to offer the product? And lastly, if the } \\
\text { insurance industry would not offer it, then who would? } \\
\text { The government? An example is the FHA and self- } \\
\text { amortizing insurance. Would need to do feasibility } \\
\text { studies. }\end{array}$ \\
\hline reg & 7.17 & $\begin{array}{l}\text { Why not a system of binding } \\
\text { interpretation to promote } \\
\text { consistency in code enforcement } \\
\text { (as used in some states with } \\
\text { statewide codes)? }\end{array}$ & (see record) \\
\hline reg & 7.252 & (see notes) & Dallas is another. \\
\hline reg & 7.311 & (see notes) & $\begin{array}{l}\text { Is there research showing resistance of local building } \\
\text { code officials to innovation? }\end{array}$ \\
\hline cost & 8.173 & (see notes) & Also, at that time, they were building for everyone, the \\
\hline
\end{tabular}




\begin{tabular}{|c|c|c|c|}
\hline 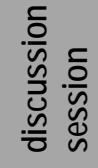 & 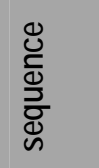 & 'flip chart' record & NIST notes \\
\hline & & & $\begin{array}{l}\text { mass market. Now, the builders are building for the } \\
\text { high end of the market, not mass market. }\end{array}$ \\
\hline cost & 8.174 & (see notes) & Because there is an existing housing stock. \\
\hline cost & 8.32 & (see notes) & It's orphan land. People don't want a long commute. \\
\hline
\end{tabular}

- Delivery system: (for housing and housing products)

\begin{tabular}{|c|c|c|c|}
\hline 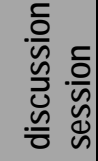 & 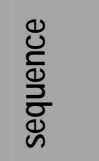 & 'flip chart' record & NIST notes \\
\hline risk & 5.12 & $\begin{array}{l}\text { Problem is materials must be sent } \\
\text { to "Fred"//rd party to put in place. } \\
\text { Systems integration is needed. } \\
\text { Capital intensive-engineered } \\
\text { product is the answer. }\end{array}$ & $\begin{array}{l}\text { We need testing under realistic, standard conditions. It } \\
\text { is extremely capital intensive to test products until } \\
\text { people start to buy them. One problem is that there } \\
\text { are disparate actors in the assembly process. It is not } \\
\text { just the design of the product. It will fail if there is no } \\
\text { systems integration. Must also consider Fred the } \\
\text { manufacturer, assembler, contractor. Products with } \\
\text { integration challenges are more likely to fail. } \\
\text { Engineered products will be superior to assembled } \\
\text { products. It will happen in the housing industry in the } \\
\text { next } 5 \text { years to } 10 \text { years. Big companies doing this will } \\
\text { succeed. }\end{array}$ \\
\hline $\operatorname{cost}$ & 8.06 & $\begin{array}{l}\text { Government has moved away from } \\
\text { any consideration of 'command and } \\
\text { control' strategies; public benefits of } \\
\text { improved housing have been } \\
\text { dismissed; tax breaks and R\&D } \\
\text { have been eliminated. }\end{array}$ & $\begin{array}{l}\text { Except for the command and control nature of } \\
\text { Operation Breakthrough, this is a good example. } \\
\text { Where is the government part in these costs? There } \\
\text { are many public benefits to society of some of these } \\
\text { development costs. For example, NIH and } \\
\text { pharmaceuticals. This is now inadequate. Need tax } \\
\text { subsidies, research and development, risk coverage } \\
\text { (coinsurance), education, and marketing. As was } \\
\text { previously mentioned, } 30 \text { years ago, BFRL was a } \\
\text { major source of basic research. }\end{array}$ \\
\hline $\operatorname{cost}$ & 8.071 & (see notes) & $\begin{array}{l}\text { This would never happen. Encouraging home } \\
\text { ownership has been the policy of every administration. }\end{array}$ \\
\hline cost & 8.091 & (see notes) & $\begin{array}{l}\text { What about labeling, such as Energy Star? New York } \\
\text { State has done more on this than any other state, to } \\
\text { decrease energy consumption. The construction } \\
\text { industry wants to publicize these risks and expenses } \\
\text { (i.e., have these risks and expenses borne by the } \\
\text { public). }\end{array}$ \\
\hline cost & 8.093 & (see notes) & It does not look for public help, either. \\
\hline cost & 8.10 & $\begin{array}{l}\text { Substantial public investment is not } \\
\text { a consideration. }\end{array}$ & (see record) \\
\hline
\end{tabular}


- Market: supply-chain, builder, homebuyer, investor

\begin{tabular}{|c|c|c|c|}
\hline 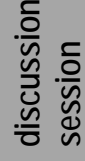 & 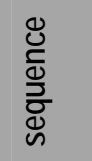 & 'flip chart' record & NIST notes \\
\hline ben & 1.03 & $\begin{array}{l}\text { Housing market is not like others: } \\
\text { - Prices/Pricing are local } \\
\text { - Not a traditional competitive } \\
\text { market (builder is part of a } \\
\text { cartel) } \\
\text { - Benefits may not pass directly } \\
\text { to home buyer } \\
\text { - What happens to industry as a } \\
\text { result of innovation? }\end{array}$ & $\begin{array}{l}\text { The housing market is not free. It is not fully } \\
\text { competitive because it depends on land availability and } \\
\text { zoning. Therefore, if an innovation is introduced that } \\
\text { should reduce costs over time, the market may not } \\
\text { respond. Housing prices are set by location decisions } \\
\text { about square footage, acreage, and local regulations. } \\
\text { There are constraints on this market. This is not a fully } \\
\text { competitive market. Building permits convey market } \\
\text { power ("a piece of the monopoly"). The question is not } \\
\text { whether the savings get passed on to the homebuyer, } \\
\text { because most likely they are not. So must look at what } \\
\text { the long-run impact of the innovation will be on the } \\
\text { market regardless of whether the savings get passed } \\
\text { on to the buyer. Pricing is based on the cost of } \\
\text { alternative homes in the community (comparables), not } \\
\text { the cost of materials. }\end{array}$ \\
\hline push & 2.23 & $\begin{array}{l}\text { 'branding' and 'bundling' may } \\
\text { stimulate demand }\end{array}$ & $\begin{array}{l}\text { There are two marketing concepts: branding and } \\
\text { bundling. Energy Star and Master Builder are brands. } \\
\text { Is there a greater willingness to pay for these brands? } \\
\text { With bundling of components and innovations, as the } \\
\text { auto industry does with the luxury package, could this } \\
\text { be a method to stimulate demand? }\end{array}$ \\
\hline push & 2.242 & (see notes) & $\begin{array}{l}\text { One of the consultants here has worked on this with } \\
\text { the EPA recently. }\end{array}$ \\
\hline
\end{tabular}

- Metric: $1^{\text {st }}$, annual, life-cycle, time-horizon, units-of-measurement, uncertainty, market signal, rating scale

\begin{tabular}{|c|c|c|c|}
\hline 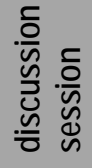 & 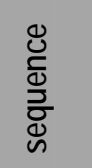 & 'flip chart' record & NIST notes \\
\hline ben & 1.18 & $\begin{array}{l}\text { May interest consumer in concern } \\
\text { about the } 1 \text { st resale period, but not } \\
\text { the } 15^{\text {th }} \text { cycle } \\
\text { Builders are concerned with } \\
\text { contemporary tastes }\end{array}$ & $\begin{array}{l}\text { The time an asset is held will determine its value. } \\
\text { Everyone considers the short run. No one is going to } \\
\text { focus on LCC currently, with rising real income levels. } \\
\text { The concern is with the } 1 \text { st and } 2 \text { nd resale, but not the } \\
\text { 15th resale. Buyers ask questions such as, "Do I have } \\
\text { the most current bathroom or kitchen?" Buyers care } \\
\text { about aesthetics, floor plan, and curb appeal. Who } \\
\text { cares about durability? }\end{array}$ \\
\hline ben & 1.381 & (see notes) & $\begin{array}{l}\text { Life-cycle costs are a function of the study period. } \\
\text { Need to include first costs. Durability to a homebuilder } \\
\text { is a shorter time period than a homeowner. There is a } \\
\text { LCC for each, but the time horizon is just increased or } \\
\text { decreased. In my experience, trades people and } \\
\text { technicians, even those with little formal education, }\end{array}$ \\
\hline
\end{tabular}




\begin{tabular}{|c|c|c|c|}
\hline 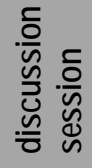 & 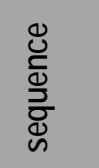 & 'flip chart' record & NIST notes \\
\hline & & & $\begin{array}{l}\text { are savvy about LCC. They know that you would not } \\
\text { put the same products into a house that you rent out } \\
\text { compared to a house that you live in (example about } \\
\text { heat pump). }\end{array}$ \\
\hline ben & 1.391 & (see notes) & $\begin{array}{l}\text { How would durability be converted into underwriting } \\
\text { criteria? To take an example, energy is quantifiable, } \\
\text { but in spite of this, it is not included. Durability would } \\
\text { be even more difficult to quantify. }\end{array}$ \\
\hline comp & 3.01 & $\begin{array}{l}\text { Extending first discussion in terms } \\
\text { of stakeholders, timeframes, and } \\
\text { scales } \\
\text { Emphasize study period for LCC } \\
\text { (longer horizons introduce } \\
\text { additional concerns) } \\
\text { Stakeholder variations occur in } \\
\text { discount rate, time horizon, and } \\
\text { relevance of costs } \\
\text { LCC analysis is flexible, provides } \\
\text { structure, under a wide range of } \\
\text { conditions }\end{array}$ & $\begin{array}{l}\text { - ASTM defines LCC as: total cost of owning, caring } \\
\text { for (operating), and disposing of a building over a } \\
\text { study period. } \\
\text { - Discount rate: How do you value future benefits or } \\
\text { costs? } \\
\text { - Which costs are relevant to each stakeholder? } \\
\text { - What is the appropriate time horizon? }\end{array}$ \\
\hline comp & 3.241 & (see notes) & $\begin{array}{l}\text { If LCC is not treated explicitly, then it is not at all, } \\
\text { because it is a black box. }\end{array}$ \\
\hline comp & 3.253 & (see notes) & $\begin{array}{l}\text { This is the purpose of the workshop, to propose a way } \\
\text { of measuring affordability. }\end{array}$ \\
\hline comp & 3.342 & (see notes) & This is why there are no more FHA inspections. \\
\hline comp & 3.362 & (see notes) & $\begin{array}{l}\text { What if defaults on mortgages for single-family homes } \\
\text { occur? Does the value of the asset still not matter? }\end{array}$ \\
\hline cert & 4.01 & $\begin{array}{l}\text { Texas Tech blind studies of } \\
\text { recapture of costs for storm } \\
\text { mitigation-market signal (visible } \\
\text { innovation) aided market } \\
\text { acceptance } \\
\text { Risk perception (Wharton)-folks } \\
\text { cannot differentiate risks } \\
\text { Looking at incentives-insurance } \\
\text { premium reduction; reduced } \\
\text { community costs recognized thru } \\
\text { transfer tax credit if dwelling is } \\
\text { improved }\end{array}$ & $\begin{array}{l}\text { - Texas Tex Wind Center conducted an empirical } \\
\text { study of storm blinds based on a cross section of } \\
6000 \text { units to look at how additional costs are } \\
\text { recaptured when the house is sold. Market signal } \\
\text { because potential buyers could see the possible } \\
\text { results from upgrading blinds. Potential buyers could } \\
\text { see the storm blinds and the premium associated with } \\
\text { it. } \\
\text { - How do people view risks? According to a risk } \\
\text { perception study at Wharton: most people can't } \\
\text { differentiate between } 1 / 1000 \text { and } 1 / 1000000 \\
\text { probability - How can we help people understand the } \\
\text { dangers? } \\
\text { - If homeowners take steps to protect property, tax } \\
\text { rebate could be a good incentive. There are economic } \\
\text { incentives for both parties. There is an insurance } \\
\text { premium associated with a mortgage. Economic } \\
\text { incentives can be used to lower reductions in } \\
\text { insurance premiums. If you improve your dwelling, the } \\
\text { less the community has to do. Can deduct } 1 / 2 \% \text { when } \\
\text { you transfer the property. }\end{array}$ \\
\hline cert & 4.32 & $\begin{array}{l}\text { Metrics not there to either estimate } \\
\text { or justify increased costs }\end{array}$ & $\begin{array}{l}\text { Need a predictable metric to get the consumer to incur } \\
\text { the cost. }\end{array}$ \\
\hline
\end{tabular}




\begin{tabular}{|c|c|c|c|}
\hline 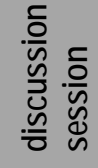 & 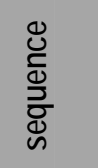 & 'flip chart' record & NIST notes \\
\hline cert & 4.37 & $\begin{array}{l}\text { Analogy to materials research- } \\
\text { better performance at lower cost- } \\
\text { need to get discussion back to } \\
\text { innovation. }\end{array}$ & $\begin{array}{l}\text { Is it possible to increase innovation and decrease cost } \\
\text { at higher quality? Can innovation make the house } \\
\text { more affordable (not the quality of the house)? Better } \\
\text { performance, better cost. }\end{array}$ \\
\hline cert & 4.373 & (see notes) & $\begin{array}{l}\text { New technology introduction costs must be borne } \\
\text { initially, but the benefits will eventually be realized. } \\
\text { High performance concrete is an example. }\end{array}$ \\
\hline risk & 5.05 & $\begin{array}{l}\text { Are consumers becoming more } \\
\text { sophisticated/sensitive to LCC? } \\
\text { Yes. }\end{array}$ & Do the customers know this? \\
\hline soc & 6.20 & $\begin{array}{l}\text { Like elegance of relying on } \\
\text { mathematical formula, but how do } \\
\text { you factor in uncertainty of } \\
\text { manufacturer claims. }\end{array}$ & $\begin{array}{l}\text { The consumer or the manufacturer? We need data on } \\
\text { reliability. For example, my " } 20 \text { year roof" had to be } \\
\text { replaced after only } 4 \text { years. }\end{array}$ \\
\hline
\end{tabular}

- Perspective: interest, standing, constituents

\begin{tabular}{|c|c|c|c|}
\hline 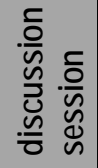 & 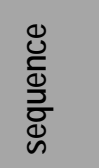 & 'flip chart' record & NIST notes \\
\hline ben & 1.01 & $\begin{array}{l}\text { Stakeholder groups: } \\
\text { - Homeowners } \\
\text { - Homebuilders } \\
\text { - } \quad \text { Product manufacturers } \\
\text { - Complementary groups } \\
\text { interested in longevity after } \\
\text { construction-lenders, } \\
\text { insurers, community, etc. }\end{array}$ & $\begin{array}{l}\text { Defining: Who benefits from the technology? } \\
\text { Major stakeholders: } \\
\text { 1. Homeowners } \\
\text { 2. Home builders: affect costs; are key leverage point } \\
\text { in passing along costs, and bringing technology } \\
\text { and benefits to home buyers } \\
\text { 3. Product manufacturers } \\
\text { 4. Housing institutions: lenders, insurers, utilities. } \\
\text { Affected by longevity of house after construction } \\
\text { and how house is utilized after construction } \\
\text { Need to look at life-cycle costs (LCC). }\end{array}$ \\
\hline ben & 1.37 & $\begin{array}{l}\text { Appraisers and realtors are very } \\
\text { important in private market }\end{array}$ & $\begin{array}{l}\text { Another problem is that appraisers do not have } \\
\text { sufficient technical knowledge or do not have } \\
\text { comparables to value some improvements. }\end{array}$ \\
\hline comp & 3.091 & (see notes) & $\begin{array}{l}\text { But regulators would not object if insurance } \\
\text { companies wanted to lower premiums. }\end{array}$ \\
\hline comp & 3.19 & $\begin{array}{l}\text { Never seen an economics } \\
\text { discussion at a codes hearing } \\
\text { (contrary example cited: stair } \\
\text { geometry cost implications stopped } \\
\text { adoption) }\end{array}$ & $\begin{array}{l}\text { In my experience, economics are not discussed at } \\
\text { proposed code changes, with one exception. In that } \\
\text { case, about eight or nine years ago, there was a } \\
\text { proposal to change stair geometry. This proposed } \\
\text { change would have changed the footprints of most } \\
\text { townhomes in the United States. Economic analysis } \\
\text { was commissioned, and the proposal was eventually } \\
\text { dropped. But the code world in general does not } \\
\text { conduct economic assessment of proposed changes } \\
\text { because the assessments are too expensive. }\end{array}$ \\
\hline cert & 4.35 & $\begin{array}{l}\text { Why will insurers push for code } \\
\text { changes, but have no interest in }\end{array}$ & $\begin{array}{l}\text { Why do codes and changes in existing codes not } \\
\text { target individual housing more directly? }\end{array}$ \\
\hline
\end{tabular}




\begin{tabular}{|c|c|c|c|}
\hline 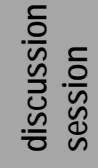 & 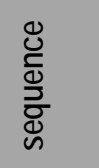 & 'flip chart' record & NIST notes \\
\hline & & QA/QC for homebuilders? & $\begin{array}{l}\text { Code changes in Florida occurred in part due to a } \\
\text { push by insurance companies. Why do they not also } \\
\text { push for enforcement and deal with the quality of the } \\
\text { house, which matters much more for affordability and } \\
\text { their risk exposure? }\end{array}$ \\
\hline risk & 5.06 & $\begin{array}{l}\text { NES 'look beyond code' push } 2 \\
\text { years ago; manufacturers wanted } \\
\text { nothing to do with it. }\end{array}$ & $\begin{array}{l}\text { Other manufacturers may not be interested in testing } \\
\text { and assessment. }\end{array}$ \\
\hline risk & 5.29 & $\begin{array}{l}\text { Housing improvement has never } \\
\text { been an objective of government. }\end{array}$ & $\begin{array}{l}\text { With agriculture, the public sector funds a great deal of } \\
\text { basic research, with the motivation and rationale that } \\
\text { what benefits the farmers will benefit society. Except } \\
\text { for Operation Breakthrough in 1968-1972, there has } \\
\text { been a lack of motivation in the case of building } \\
\text { research parallel to agriculture. }\end{array}$ \\
\hline SOC & 6.211 & (see notes) & $\begin{array}{l}\text { The paranoia is justified because the fear is that an } \\
\text { intellectual exercise will lead to the easy "fallback" } \\
\text { approach: regulation. }\end{array}$ \\
\hline
\end{tabular}

- Product: development, test/evaluation, distribution, sale

\begin{tabular}{|c|c|c|c|}
\hline 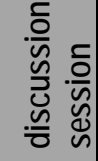 & 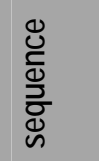 & 'flip chart' record & NIST notes \\
\hline risk & 5.08 & $\begin{array}{l}\text { Lots of visible innovation is by small } \\
\text { companies with low capitalization } \\
\text { looking to push innovation into } \\
\text { market with little testing or success. }\end{array}$ & $\begin{array}{l}\text { The concern is this, truly innovative producers are very } \\
\text { small-scale producers, who may not have the } \\
\text { resources to test and are the worst when it comes to } \\
\text { assessing products before market introduction. } \\
\text { Massive industry failures are documented on PATH's } \\
\text { website. HUD did a study of EIFS and engineered I- } \\
\text { joists. With EIFS, which was a failure, it was produced } \\
\text { by small, fly-by-night producers who did not do } \\
\text { homework on the proper application of the technology. } \\
\text { With engineered I-joists, which was a success, the } \\
\text { producers were big companies who had performed } \\
\text { long, comprehensive analysis of the product and } \\
\text { process. There is a riskiness to new products that is } \\
\text { inherent that is not addressed by producers. In the } \\
\text { ICC Evaluation Service guide to innovations, the idea } \\
\text { is "getting the technology accepted." }\end{array}$ \\
\hline risk & 5.101 & (see notes) & $\begin{array}{l}\text { How much does this manufacturer use the ICC } \\
\text { Evaluation Service? }\end{array}$ \\
\hline risk & 5.111 & (see notes) & $\begin{array}{l}\text { The drug industry is a poor example. The FDA is a } \\
\text { notorious bottleneck, and the process drives up the } \\
\text { cost of drugs. }\end{array}$ \\
\hline risk & 5.132 & (see notes) & $\begin{array}{l}\text { With autos, though, the components are highly } \\
\text { engineered. }\end{array}$ \\
\hline risk & 5.16 & $\begin{array}{l}\text { Are manufacturers willing to take } \\
\text { risk that consumer will buy a higher }\end{array}$ & $\begin{array}{l}\text { What are the steps in the introduction of new } \\
\text { products? Does your company introduce new }\end{array}$ \\
\hline
\end{tabular}




\begin{tabular}{|c|c|c|c|}
\hline 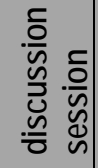 & 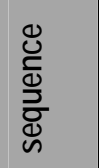 & 'flip chart' record & NIST notes \\
\hline & & priced product? & $\begin{array}{l}\text { products knowing that they initially will have a higher } \\
\text { cost than the incumbent, but with adoption, the cost } \\
\text { may fall? }\end{array}$ \\
\hline risk & 5.215 & (see notes) & Need risk insurance or vertical integration. \\
\hline cost & 8.12 & $\begin{array}{l}\text { Have not heard 'pilot project' as an } \\
\text { approach (analogy to medical } \\
\text { industry); allows not total change, } \\
\text { but immediate test of change. }\end{array}$ & $\begin{array}{l}\text { What about pilot projects with interface between } \\
\text { private and public/government entities? Should not be } \\
\text { all or nothing. Deep-pocketed publicly owned } \\
\text { companies have to be the first movers of new } \\
\text { innovations, with some help from government. }\end{array}$ \\
\hline cost & 8.121 & (see notes) & Only peanuts go into these projects. \\
\hline cost & 8.122 & (see notes) & $\begin{array}{l}\text { Even if small scale, it may be helpful for a specific } \\
\text { area, such as flood plains in lowa. }\end{array}$ \\
\hline cost & 8.13 & $\begin{array}{l}\text { 'Pilot project' may not work well } \\
\text { because of conflict with existing } \\
\text { infrastructure; change may be } \\
\text { viewed as negative-if the pilot is } \\
\text { big, it may be blocked by existing } \\
\text { industry and consumer afraid of } \\
\text { reduced asset value. }\end{array}$ & $\begin{array}{l}\text { There must be a limited role for government. There } \\
\text { are parties who will be losers with these changes. If } \\
\text { you cut the cost by } 30 \% \text {, that is fundamentally } \\
\text { disruptive to the market price for homes. }\end{array}$ \\
\hline cost & 8.132 & (see notes) & $\begin{array}{l}\text { The first mover probably would price without cutting by } \\
30 \% \text { and would capture economic rents. It will be } \\
\text { deep pocket publicly held companies doing this. }\end{array}$ \\
\hline
\end{tabular}

- Segmentation: MF/SF, new/existing, low-income/high-income

\begin{tabular}{|c|c|c|c|}
\hline 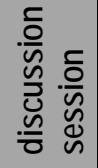 & 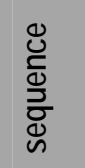 & 'flip chart' record & NIST notes \\
\hline ben & 1.19 & $\begin{array}{l}\text { Homeowners are not a } \\
\text { homogenous group; } 2^{\text {nd }} \text { time buyers } \\
\text { have much different interests than } \\
\text { 1st timers }\end{array}$ & $\begin{array}{l}\text { There is diversity among buyers. There is a huge } \\
\text { difference between concerns for } 1 \text { st-time homebuyers } \\
\text { and } 2 \text { nd time buyers. According to a survey, } 1 \text { st time } \\
\text { homebuyers look at first cost and location. Second- } \\
\text { time homebuyers, however, pay more attention to } \\
\text { long-term durability because of the experiences they } \\
\text { may have had with their first home. Realtors and } \\
\text { appraisers need to bring these issues into their } \\
\text { discussions. }\end{array}$ \\
\hline ben & 1.41 & $\begin{array}{l}\text { Maybe rating system is more } \\
\text { suitable/appropriate for 'existing } \\
\text { stock; 1st buyers are the least } \\
\text { constrained segment }\end{array}$ & $\begin{array}{l}\text { The rating system can fill the information gap and start } \\
\text { the process. }\end{array}$ \\
\hline push & 2.19 & $\begin{array}{l}\text { There are definite stages of } \\
\text { innovation/penetration/adoption } \\
\text { - How do } 2^{\text {nd }} \text { and } 3^{\text {rd }} \text { stage } \\
\text { adopters make decisions? } \\
\text { - How is decision-making } \\
\text { different from group to group? } \\
0 \text { Homeowner 2nd }\end{array}$ & $\begin{array}{l}\text { There are different stages of adopters. Some builders } \\
\text { like to play with toys. For them, it is not necessarily } \\
\text { about markets. These are the lead adopters, the risk } \\
\text { takers. For innovations to diffuse, we must pay } \\
\text { attention to the next group, which comes after the } \\
\text { lead adopters but comes before the herd. For this } \\
\text { intermediate group, what do they respond to? What }\end{array}$ \\
\hline
\end{tabular}




\begin{tabular}{|c|c|c|c|}
\hline 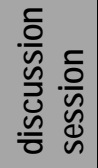 & 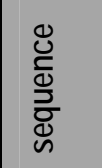 & 'flip chart' record & NIST notes \\
\hline & & $\begin{array}{l}\text { stage: follow the } \\
\text { leader } \\
\text { Homebuilder 2nd } \\
\text { stage: innovator is } \\
\text { eating my lunch } \\
\text { better change }\end{array}$ & $\begin{array}{l}\text { do we and can we know about them? For the } \\
\text { intermediate homeowner, they are the imitator. For } \\
\text { the intermediate builder, they are those who respond } \\
\text { to the competitive advantage that the early adopters } \\
\text { get. There was an NAHB/Virginia Tech study on } \\
\text { diffusion that focused mostly on the early adopters. } \\
\text { More information needs to be collected about the } \\
\text { intermediate group that follows the early adopters. }\end{array}$ \\
\hline comp & 3.36 & $\begin{array}{l}\text { Reflects more intense use of } \\
\text { existing stock; SF transaction very } \\
\text { different from MF }\end{array}$ & $\begin{array}{l}\text { Another problem is that few states certify home } \\
\text { inspectors. }\end{array}$ \\
\hline cert & 4.241 & (see notes) & Is the risk pooled or not? \\
\hline SOC & 6.04 & $\begin{array}{l}\text { We have not articulated the } \\
\text { differences between SF and MF } \\
\text { delivery. MF internalizes external } \\
\text { costs for many actors. It is the } \\
\text { difference between a private } \\
\text { transaction and a public transaction. } \\
\text { Additional R\&D on the private side } \\
\text { may be an effective approach. } \\
\text { Removal of barriers to innovation is } \\
\text { another. }\end{array}$ & $\begin{array}{l}\text { Multi-family housing does best at internalizing (Fannie } \\
\text { Mae). Because it is an investment, there is an } \\
\text { incentive for long-term concern on the part of } \\
\text { mortgage lenders. With single-family housing, the } \\
\text { issue is creditworthiness, so this incentive to have } \\
\text { concern about the long term is not there. Monetizing } \\
\text { social benefits becomes irrelevant. Need to } \\
\text { determine the constraints that exist in the housing } \\
\text { system and get them out of the way. Regulators } \\
\text { should not be a stakeholder group. They should be } \\
\text { surrogates. To what degree is the regulatory system } \\
\text { a barrier to innovation? How can the regulatory } \\
\text { system improve the health and safety of individuals? } \\
\text { One proposal is to provide the council of evaluations a } \\
\text { more comprehensive evaluation system to better } \\
\text { know these costs to those with long-term financial } \\
\text { interests. With single-family homes, these are private, } \\
\text { unregulated transactions between two parties that do } \\
\text { not have long-term financial interests. It is very } \\
\text { different from multi-family housing. }\end{array}$ \\
\hline soc & 6.05 & $\begin{array}{l}\text { No, we should not use MF as the } \\
\text { model-we should employ taxes, } \\
\text { fees, and fines for } 5 \text { year first use } \\
\text { and } 20 \text { year expected service life (it } \\
\text { realistically may be } 100 \text { years) }\end{array}$ & $\begin{array}{l}\text { Decoupling the product from the credit to pay for it } \\
\text { leads to this outcome. If a durability fee were to get } \\
\text { added to the production function, then will capture the } \\
\text { costs to society. }\end{array}$ \\
\hline Soc & 6.051 & (see notes) & This would not get done without regulation. \\
\hline SOC & 6.081 & (see notes) & Impact fees can capture these costs. \\
\hline SOC & 6.091 & (see notes) & $\begin{array}{l}\text { We can't apply lessons from multifamily housing to } \\
\text { single-family housing. }\end{array}$ \\
\hline cost & 8.21 & $\begin{array}{l}\text { Suburban } 1 \text { st home means "lawns } \\
\text { and commutes"- } \text { should we focus } \\
\text { on a different } 1 \text { st home model? }\end{array}$ & $\begin{array}{l}\text { One must consider the current housing market. The } \\
\text { problem is the need to match preferences over the } \\
\text { first home with what is available. My first home was in } \\
\text { the suburbs. It did not match my preferences. There } \\
\text { was a yard that I did not want to have to maintain. I } \\
\text { had a long commute. Need to address the } \\
\text { demographic of first-time homebuyers that do not } \\
\text { want lawn maintenance and long commutes. How } \\
\text { about rehabilitating loft apartments in the urban core? }\end{array}$ \\
\hline
\end{tabular}




\begin{tabular}{|c|c|c|c|}
\hline 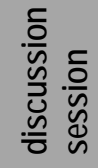 & 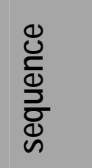 & 'flip chart' record & NIST notes \\
\hline cost & 8.23 & $\begin{array}{l}\text { Reconfigure low-density } \\
\text { neighborhoods to high density. }\end{array}$ & $\begin{array}{l}\text { Hope } 6 \text { is an example, but it is already on publicly } \\
\text { owned property. }\end{array}$ \\
\hline cost & 8.24 & $\begin{array}{l}\text { Most new homes will be sprawl and } \\
\text { SF on periphery of urban areas; } \\
\text { clearly need is for innovation in } \\
\text { existing housing stock, but most } \\
\text { new products will be for new } \\
\text { construction. } 50 \text { million new buyers } \\
\text { over next } 50 \text { years will push new } \\
\text { development even though they may } \\
\text { enter market through purchase of } \\
\text { existing stock. }\end{array}$ & $\begin{array}{l}\text { For most, the sprawl and new construction will } \\
\text { continue. People want new construction. In the next } \\
25 \text { years, existing housing will go primarily to } \\
\text { immigrants, so there will a number of new housing } \\
\text { starts. }\end{array}$ \\
\hline cost & 8.242 & (see notes) & $\begin{array}{l}\text { There is a lack of technology directed at the existing } \\
\text { housing stock. Most of the products are targeted to } \\
\text { new homes. This will affect who pays and bears the } \\
\text { costs of new product development. }\end{array}$ \\
\hline
\end{tabular}

- Value: cost, price, benefit

\begin{tabular}{|c|c|c|c|}
\hline 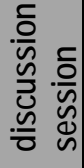 & 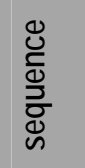 & 'flip chart' record & NIST notes \\
\hline ben & 1.06 & $\begin{array}{l}\text { Homebuilders must compete by } \\
\text { adding value }\end{array}$ & $\begin{array}{l}\text { Would like to see builders competing on quality, rather } \\
\text { than on first cost, that is, based on the value of the } \\
\text { house rather than its first cost. We are trying to get } \\
\text { from first costs to LCC. When first costs are } \\
\text { decreased, LCC are higher and consumers bear the } \\
\text { burden of this increase. }\end{array}$ \\
\hline cert & 4.38 & $\begin{array}{l}\text { Housing only industry to insist that } \\
\text { innovation requires increased costs. }\end{array}$ & $\begin{array}{l}\text { Housing is the only industry that focuses only on the } \\
\text { increase in initial or early costs associated with } \\
\text { innovation. This is not true in other industries. In the } \\
\text { housing market, initial costs always increase with } \\
\text { increased innovations. Innovation costs more in the } \\
\text { long term. Pulte improved the quality in its framing. }\end{array}$ \\
\hline risk & 5.03 & $\begin{array}{l}\text { How do you treat cost of substitute } \\
\text { products? }\end{array}$ & $\begin{array}{l}\text { Is affordability a factor in marketing decisions at your } \\
\text { company? }\end{array}$ \\
\hline
\end{tabular}

\section{Consultants}

- Attribute: affordability, durability, safety, etc. (flexibility, substitutability, customizability) 


\begin{tabular}{|c|c|c|c|}
\hline 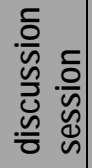 & 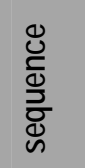 & 'flip chart' record & NIST notes \\
\hline ben & 1.31 & $\begin{array}{l}\text { Durability measurement has been } \\
\text { supported by component } \\
\text { manufacturers, opposed by } \\
\text { materials suppliers, and opposed by } \\
\text { builders (because already factored } \\
\text { into markets) }\end{array}$ & $\begin{array}{l}\text { The market is having trouble swallowing guidelines } \\
\text { such as durability ratings. Who supported the } \\
\text { durability standard at ASTM? The components } \\
\text { manufacturers. Who didn't? The raw materials } \\
\text { suppliers, including gypsum producers, assemblers, } \\
\text { and builders. These groups argued that the market } \\
\text { already values durability, and therefore do not need } \\
\text { more information. There is a need to measure the } \\
\text { performance of the house. }\end{array}$ \\
\hline push & 2.25 & $\begin{array}{l}\text { Ability to provide customization of } \\
\text { components is an advantage for } \\
\text { builders }\end{array}$ & $\begin{array}{l}\text { EPA's approach to marketing Energy Star was trial } \\
\text { and error. It began by trying to sell Energy Star using } \\
\text { fact sheets. This did not work. But when EPA began } \\
\text { to distribute information about Energy Star using CD- } \\
\text { ROMs, which is a customizable medium that builders } \\
\text { could use to choose what to compete on and put their } \\
\text { names on, the label took off. }\end{array}$ \\
\hline push & 2.26 & (see notes) & $\begin{array}{l}\text { This is an example of a "push." The electronic } \\
\text { dissemination of information has become more } \\
\text { desirable. For example, a builder allowing buyers to } \\
\text { do a virtual walk-through of a model is a big push. }\end{array}$ \\
\hline cert & 4.08 & $\begin{array}{l}\text { - Information used quite different } \\
\text { among groups } \\
\text { - How communicated is very } \\
\text { important (easier to deal with } \\
\text { dollars than life-safety of } \\
\text { specific event) } \\
\text { - Commerce looked closely at } \\
\text { business interruption impacts }\end{array}$ & $\begin{array}{l}\text { There is a role for financiers and insurers. FEMA is } \\
\text { funding the Applied Technology Council (ATC) } 58 \\
\text { project. Some of the results are that the sophistication } \\
\text { with which the point is made matters, such as it is in } \\
\text { terms of life losses or economic losses. People can } \\
\text { deal much better with economic losses in terms of } \\
\text { annualized expected loss associated with a choice or } \\
\text { action, rather than an event. Larger corporations are } \\
\text { concerned with investment and maintaining the ability } \\
\text { to continue running. For example, if it were presented } \\
\text { as probability of minor damage vs. probability of major } \\
\text { damage. People's normal lifetime experiences do not } \\
\text { allow them to factor for extreme events. }\end{array}$ \\
\hline cert & 4.20 & $\begin{array}{l}\text { Hurricane protection relies on } \\
\text { maintenance rather than } \\
\text { passive/fail-safe approach. }\end{array}$ & $\begin{array}{l}\text { With hurricanes, there are three mitigation approaches } \\
\text { that are seen as equivalent by the codes. } \\
\text { 1. Build hurricane shutters, and the only } \\
\text { maintenance required is to close them before } \\
\text { the hurricane hits. } \\
\text { 2. Install impact-resistant windows, and the } \\
\text { only maintenance is to close them before the } \\
\text { storm. } \\
\text { 3. Stack plywood, and the maintenance action } \\
\text { is to put it up when the hurricane warning } \\
\text { comes. } \\
\text { Whether high maintenance or low maintenance, there } \\
\text { are options to satisfy the need for protection. The } \\
\text { codes recognize that some prefer low maintenance } \\
\text { and some high. } \\
\text { Standards are met if you are building in a low } \\
\text { frequency event area. }\end{array}$ \\
\hline cert & 4.26 & Many SF homes with cripple walls & There were some retrofits, such as the Parapet \\
\hline
\end{tabular}




\begin{tabular}{|c|c|c|c|}
\hline 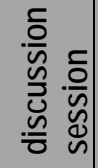 & 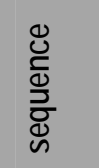 & 'flip chart' record & NIST notes \\
\hline & & have the same problem. & $\begin{array}{l}\text { program and unreinforced masonry buildings (URMB). } \\
\text { It is difficult to get these programs in place. There } \\
\text { needs to be a public outcry. }\end{array}$ \\
\hline cert & 4.262 & (see notes) & $\begin{array}{l}\text { I have no seismic insurance even though I live in } \\
\text { California because any policy with a reasonable } \\
\text { premium has a deductible of } \$ 40000 \text {. This creates an } \\
\text { incentive for me to build better. }\end{array}$ \\
\hline risk & 5.30 & $\begin{array}{l}\text { When they say "affordability", } \\
\text { respond with "basic research". Even } \\
\text { basic "affordability" is beyond code } \\
\text { compliance requirements. }\end{array}$ & $\begin{array}{l}\text { As a country, we do not invest much in basic research } \\
\text { and testing in the housing industry (in the public } \\
\text { sector). In general, basic affordability is beyond the } \\
\text { code minimums. } \\
\text { We have to keep in mind that nobody would buy a } \\
\text { code-minimum house. Such a house has no wall } \\
\text { board, no paint, no carpet. The market prevents code- } \\
\text { minimum houses. Most of the affordability equation is } \\
\text { beyond the code. Therefore, must look at the } \\
\text { unregulated component of housing. }\end{array}$ \\
\hline
\end{tabular}

- Barrier/Incentive: (to market acceptance)

\begin{tabular}{|c|c|c|c|}
\hline 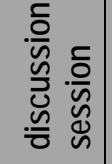 & 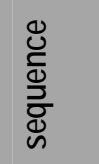 & 'flip chart' record & NIST notes \\
\hline ben & 1.26 & $\begin{array}{l}\text { The important issue is who } \\
\text { decides-don't understand what is } \\
\text { meant by 'affordability' } \\
\text { - What are policies that affect } \\
\text { affordability, that affect } \\
\text { homebuyer and other } \\
\text { perceptions? } \\
\text { - How do you get information to } \\
\text { consumers? }\end{array}$ & $\begin{array}{l}\text { This is driven by stakeholders. One example was the } \\
\text { requirement that all homes in one area be all-electric. } \\
\text { This was a disaster. Cannot sell the consumer short. } \\
\text { It is LCC. They just need the information. }\end{array}$ \\
\hline ben & 1.39 & $\begin{array}{l}\text { Is the financing of the first buyer (of } \\
\text { innovation) an opportunity for } \\
\text { incentives? }\end{array}$ & $\begin{array}{l}\text { Is the financing for the first buyer of the innovation an } \\
\text { opportunity for incentives? }\end{array}$ \\
\hline push & 2.041 & (see notes) & Sprinklers in multifamily homes are now required. \\
\hline push & 2.103 & (see notes) & $\begin{array}{l}\text { [elaborated on the notion of tradeoffs as he intended } \\
\text { the question when writing it.] }\end{array}$ \\
\hline comp & 3.311 & (see notes) & $\begin{array}{l}\text { Officials in New York State have stated that adoption } \\
\text { of building codes was based on costs and benefits. } \\
\text { Regulator stakeholders are multidimensional and } \\
\text { heterogeneous. Political jurisdictions affect this. }\end{array}$ \\
\hline cert & 4.361 & (see notes) & Zoning is an issue. \\
\hline risk & 5.26 & $\begin{array}{l}\text { Over-emphasis of regulated side of } \\
\text { costs; should we shift focus to non- } \\
\text { regulated side? We no longer invest } \\
\text { in basic research. }\end{array}$ & $\begin{array}{l}\text { There is insufficient basic research in the public sector } \\
\text { that leads to innovation. Also, have to look at the } \\
\text { unregulated components of housing. }\end{array}$ \\
\hline
\end{tabular}




\begin{tabular}{|c|c|c|c|}
\hline 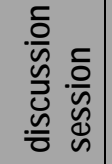 & 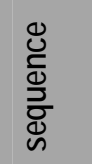 & 'flip chart' record & NIST notes \\
\hline SOC & 6.11 & $\begin{array}{l}\text { We need to ask why we are } \\
\text { concerned with social costs: } \\
\text { - } \quad \text { 3rd }^{\text {rd }} \text { party effects are fair } \\
\text { game for incentives } \\
\text { - Mandates should not be } \\
\text { based on externalities } \\
\text { - Externalities should be } \\
\text { viewed very skeptically. }\end{array}$ & $\begin{array}{l}\text { Why are we even trying to monetize costs and } \\
\text { benefits? There are two extreme motivations. The } \\
\text { first is to promote technology development with } \\
\text { enlightened policies. If we are trying to do this, then } \\
\text { monetize costs and benefits. The second is to provide } \\
\text { justification for more regulations. If this is the case, } \\
\text { then will lead to more skepticism. A problem is that } \\
\text { everything is an externality. They can be seen } \\
\text { everywhere, and the exercise of monetizing them } \\
\text { would never end. In any case, with regard to the } \\
\text { example of solid waste disposal, I have to pay a waste } \\
\text { disposal fee every year. }\end{array}$ \\
\hline SOC & 6.13 & $\begin{array}{l}\text { Regulation is often an adaptation to } \\
\text { real circumstances }\end{array}$ & $\begin{array}{l}\text { We need to focus on reforming regulations which } \\
\text { improve affordability for everybody, not just removing } \\
\text { regulations. }\end{array}$ \\
\hline SOC & 6.132 & (see notes) & $\begin{array}{l}\text { The assumption in code reform is that the original } \\
\text { regulations were right. }\end{array}$ \\
\hline reg & 7.19 & That's a disappointing point of view. & That perspective is disappointing. \\
\hline reg & 7.22 & $\begin{array}{l}\text { 10-point ISO rating system looks } \\
\text { comprehensively at code } \\
\text { enforcement. Do they look at use of } \\
\text { NES reports? }\end{array}$ & $\begin{array}{l}\text { A participant earlier mentioned the 10-point ISO } \\
\text { certification rating system on the adoption, provision, } \\
\text { number of inspectors, training, of inspectors, of code. } \\
\text { Could build on this tool. With this rating, did they use } \\
\text { evaluation service reports (ESRs)? }\end{array}$ \\
\hline reg & 7.23 & $\begin{array}{l}\text { Short answer is no, but do not put } \\
\text { all eggs in one basket-I accept } \\
\text { NES reports only if I agree; I rely on } \\
\text { multiple sources of information. }\end{array}$ & $\begin{array}{l}\text { No. They might, they might not. Evaluation reports } \\
\text { are not always accepted. I might not accept one that I } \\
\text { do not agree with, because evaluation is also subject } \\
\text { to human error. I am as receptive toward products } \\
\text { with ESRs as I am toward those without them. The } \\
\text { lack of a report should not always be viewed as a } \\
\text { barrier to acceptance. }\end{array}$ \\
\hline reg & 7.29 & $\begin{array}{l}\text { Barriers at local level may be } \\
\text { politically based. }\end{array}$ & $\begin{array}{l}\text { Officials want to offload risk; they do not want the } \\
\text { liability. For example, EIFS. You could get a political } \\
\text { barrier. Maybe a union will not let a code change in, } \\
\text { and they are told not to improve it or will fight to keep } \\
\text { new technology out when code changes are proposed. } \\
\text { Even in spite of scientific justification for a } \\
\text { component's use, there may be politically motivated } \\
\text { resistance. An example is steel framing and the } \\
\text { influence of California unions on local officials. } \\
\text { Political issues may similarly arise with respect to code } \\
\text { language and interpretations of the code. }\end{array}$ \\
\hline cost & 8.28 & $\begin{array}{l}\text { Planned development approaches } \\
\text { allow flexibility in zoning. Is it time } \\
\text { now to plan for future use by adding } \\
\text { flexibility to be adaptable to and } \\
\text { facilitate future rehab. } \\
\text { Resistance to modular housing at } \\
\text { local level cannot be explained by } \\
\text { differences over time. }\end{array}$ & $\begin{array}{l}\text { Must look at the role of zoning, density, and cost. In a } \\
\text { new market, see planned residential/housing } \\
\text { developments (PRD/PHD). Are these viable and } \\
\text { durable, or will they decay and people will move? } \\
\text { Also, can we plan for } 30 \text { years to } 40 \text { years from now } \\
\text { by reorienting the layout of a home? Systems-wide } \\
\text { engineering could be used to facilitate future rehab. } \\
\text { For example, to be able to move a load-bearing wall to } \\
\text { change the floor plan to satisfy future tastes, needs, }\end{array}$ \\
\hline
\end{tabular}




\begin{tabular}{|c|c|c|c|}
\hline 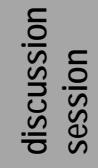 & 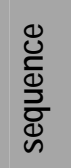 & 'flip chart' record & NIST notes \\
\hline & & & $\begin{array}{l}\text { and preferences. Use more partitions. Make the } \\
\text { kitchen a module that can be plugged in or unplugged } \\
\text { and moved. }\end{array}$ \\
\hline cost & 8.33 & (see notes) & $\begin{array}{l}\text { Regarding the acceptance or resistance to modules, } \\
\text { the resistance is based on historical experience } \\
\text { because there may be different or reduced standards } \\
\text { in one house compared to the house next door. } \\
\text { Modularization would lead to loss of local control. }\end{array}$ \\
\hline cost & 8.35 & (see notes) & Was it a hard or easy swallow for local officials? \\
\hline
\end{tabular}

- Delivery system: (for housing and housing products)

\begin{tabular}{|c|c|c|c|}
\hline 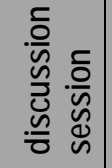 & 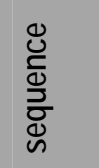 & 'flip chart' record & NIST notes \\
\hline reg & 7.12 & $\begin{array}{l}\text { Look at entire regulatory system- } \\
\text { currently consists of prescriptive } \\
\text { frailty with alternative options. } \\
\text { (liability/technical issues go beyond } \\
\text { the capability of the field code } \\
\text { official) Frailty is the confidence that } \\
\text { prescriptive codes achieve desired } \\
\text { purposes/objectives. Tons of } \\
\text { innovation is just not used. Need to } \\
\text { better understand frailties and } \\
\text { impediments. }\end{array}$ & $\begin{array}{l}\text { The status quo is a prescriptive system with an } \\
\text { allowance for alternatives. Allowance has frailty } \\
\text { because it is subject to human acceptance. Any } \\
\text { solution would have to address this frailty. Examples } \\
\text { of solutions would be liability, education and technical } \\
\text { training, access to technical information. Another } \\
\text { frailty is whether the current prescriptive codes are on } \\
\text { the mark. With the hybrid, as one of the model code } \\
\text { developers discussed, there would still be liability and } \\
\text { education frailties. Another consideration is that many } \\
\text { innovations are not being used. They need selling and } \\
\text { marketing, but the performance side is harder to cover } \\
\text { liability. There would need to be understanding of the } \\
\text { components of the system. Lack of existing standards } \\
\text { can be a bigger barrier than regulations. }\end{array}$ \\
\hline cost & 8.03 & $\begin{array}{l}\text { We are asked to look at these } \\
\text { issues at material/component scale } \\
\text { and at product delivery scale. }\end{array}$ & $\begin{array}{l}\text { It was proposed that we look at technology at two } \\
\text { scales, the components/materials scale and the whole } \\
\text { house and delivery system scale. }\end{array}$ \\
\hline cost & 8.07 & $\begin{array}{l}\text { Should a change in the form of } \\
\text { ownership be considered? }\end{array}$ & $\begin{array}{l}\text { FHA mortgage insurance in the U.S. in the 1930s } \\
\text { through } 1950 \text { s created the current housing delivery } \\
\text { system. Participants have given other examples of } \\
\text { innovations in the housing delivery system. One } \\
\text { possibility would be to change the form of } \\
\text { homeownership. }\end{array}$ \\
\hline cost & 8.072 & (see notes) & $\begin{array}{l}\text { If housing were a service rather than property, then it } \\
\text { could be different. }\end{array}$ \\
\hline cost & 8.14 & $\begin{array}{l}\text { Could be the subject of study-is } \\
\text { there a role for government in a test } \\
\text { of changing housing delivery? }\end{array}$ & $\begin{array}{l}\text { There was a NSF project funded by Alcoa, Gulf, and } \\
\text { Westinghouse (General Electric), which followed } \\
\text { Operation Breakthrough to ask whether there was a } \\
\text { role for these types of companies in housing delivery. } \\
\text { The answer they arrived at was, probably not. Now, } \\
\text { Fannie and Freddie have come, the National } \\
\text { Evaluation Service and others have developed. Given }\end{array}$ \\
\hline
\end{tabular}




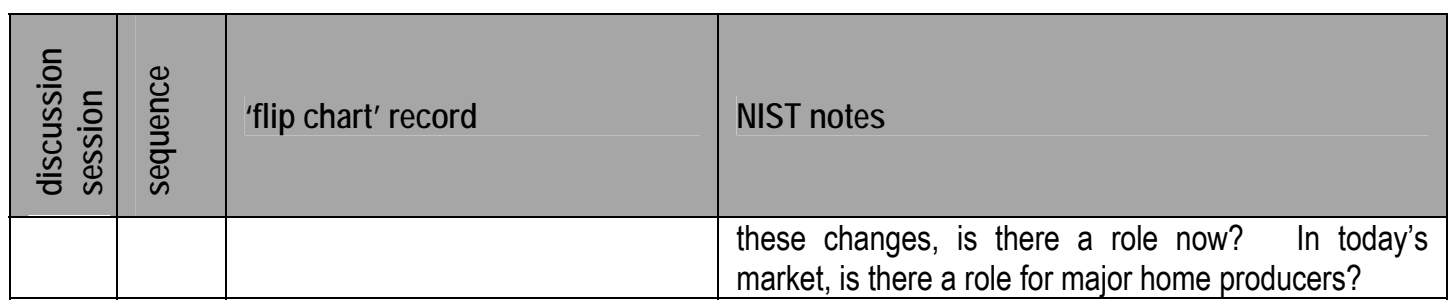

- Market: supply-chain, builder, homebuyer, investor

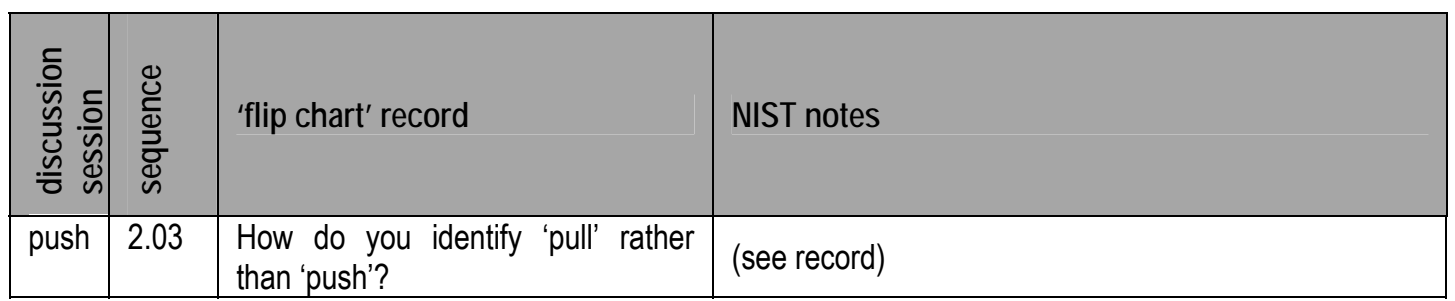

- Metric: $1^{\text {st }}$, annual, life-cycle, time-horizon, units-of-measurement, uncertainty, market signal, rating scale

\begin{tabular}{|c|c|c|c|}
\hline 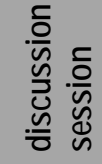 & 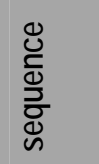 & 'flip chart' record & NIST notes \\
\hline comp & 3.23 & $\begin{array}{l}\mathrm{GFCl} \text { introduction to codes was } \\
\text { argued from both standpoints, but } \\
\text { not in public discussions }\end{array}$ & $\begin{array}{l}\text { There are two other examples. LCC analysis was } \\
\text { done on a NIST project on GFCl and on safety } \\
\text { glazing, and they are now in all codes. }\end{array}$ \\
\hline comp & 3.255 & (see notes) & Insurers know how to do this. \\
\hline comp & 3.27 & $\begin{array}{l}\text { Smoke detector example: } \\
\text { production reduced costs from } \$ 100 \\
\text { to } \$ 5 \text { and changed the economics }\end{array}$ & $\begin{array}{l}\text { Several years ago, when smoke detectors cost over } \\
\$ 100 \text { each, the decision was more difficult. Now that } \\
\text { they cost a few dollars, nobody objects to their } \\
\text { inclusion in the code. }\end{array}$ \\
\hline cert & 4.021 & (see notes) & $\begin{array}{l}\text { What is often ignored is that risk has two dimensions, } \\
\text { both the probability of the event and the } \\
\text { consequences. Must balance with magnitude of an } \\
\text { improbable event with the magnitude of the possible } \\
\text { damage. }\end{array}$ \\
\hline cert & 4.03 & $\begin{array}{l}\text { Insurance Services Organization } \\
\text { (ISO) program to rate communities } \\
\text { and code enforcement }\end{array}$ & $\begin{array}{l}\text { The Insurance Services Office (ISO) conducts the } \\
\text { BCEGS (Building Code Effectiveness Grading } \\
\text { Schedule) program about the quality of codes and } \\
\text { code enforcement. The insurance industry uses this } \\
\text { data. }\end{array}$ \\
\hline cert & 4.181 & (see notes) & $\begin{array}{l}\text { If the penalty is less than the cost of maintenance, } \\
\text { then the incentive to maintain is not there. }\end{array}$ \\
\hline cert & 4.321 & (see notes) & $\begin{array}{l}\text { Or wait for an event to occur to make them want to } \\
\text { incur it. }\end{array}$ \\
\hline soc & 6.204 & (see notes) & Like fuel efficiency for automobiles. \\
\hline
\end{tabular}


- Perspective: interest, standing, constituents

\begin{tabular}{|c|c|c|c|}
\hline 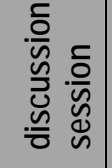 & 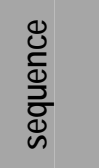 & 'flip chart' record & NIST notes \\
\hline comp & 3.08 & $\begin{array}{l}\text { Need to look at insurance business } \\
\text { model-loss control }\end{array}$ & (see record) \\
\hline comp & 3.09 & $\begin{array}{l}\text { Complex situation; insurance is } \\
\text { highly regulated for both consumer } \\
\text { and industry protection issues }\end{array}$ & State regulators are political animals. \\
\hline comp & 3.14 & $\begin{array}{l}\text { Code officials are responsible to } \\
\text { occupants. }\end{array}$ & $\begin{array}{l}\text { The interest of the regulators becomes parallel with } \\
\text { that of the homeowners. }\end{array}$ \\
\hline comp & 3.29 & $\begin{array}{l}\text { Code official is both stakeholder } \\
\text { and part of production team }\end{array}$ & $\begin{array}{l}\text { The lag bolt would probably have met the minimum } \\
\text { performance standard, but the code official may have } \\
\text { lacked the technical background to know this. This is } \\
\text { a recognized problem. The problem is that code } \\
\text { officials are not involved in the design stage and are } \\
\text { only brought in at the end of the process. When they } \\
\text { have objections at this point, they are seen as } \\
\text { impediments. }\end{array}$ \\
\hline cert & 4.05 & $\begin{array}{l}\text { How do you communicate } \\
\text { magnitude, probability, and } \\
\text { performance to each stakeholder } \\
\text { group }\end{array}$ & $\begin{array}{l}\text { Magnitude of a loss is based on the magnitude of the } \\
\text { initial event. Risk of building falling down comes from } \\
\text { how well the initial design was equipped to handle } \\
\text { wind, for example. Certain embedded assumptions as } \\
\text { to how to make decisions. People are trying to } \\
\text { understand quantitative data on a qualitative level. } \\
\text { People's normal lifetime experiences do not allow } \\
\text { them to factor for extreme events. Consideration of } \\
\text { life loss vs. economic loss - larger corporations are } \\
\text { concerned with investment and maintaining the ability } \\
\text { to continue running. }\end{array}$ \\
\hline cert & 4.122 & (see notes) & $\begin{array}{l}\text { How does a neighbor become a stakeholder is your } \\
\text { house? When something significant occurs to a single } \\
\text { home, it affects the entire neighborhood (in way of } \\
\text { market value). }\end{array}$ \\
\hline risk & 5.281 & (see notes) & $\begin{array}{l}\text { Just look at old National Bureau of Standards (NBS) } \\
\text { publications. It used to all be basic research. }\end{array}$ \\
\hline soc & 6.21 & $\begin{array}{l}\text { Many stakeholders have an } \\
\text { inordinate fear of regulation }\end{array}$ & $\begin{array}{l}\text { NIST developed durability performance standards } \\
\text { purely based on technical considerations. It led to } \\
\text { paranoia. This was fought by, among others, } \\
\text { homebuilders, at ASTM meetings. }\end{array}$ \\
\hline
\end{tabular}

- Product: development, test/evaluation, distribution, sale

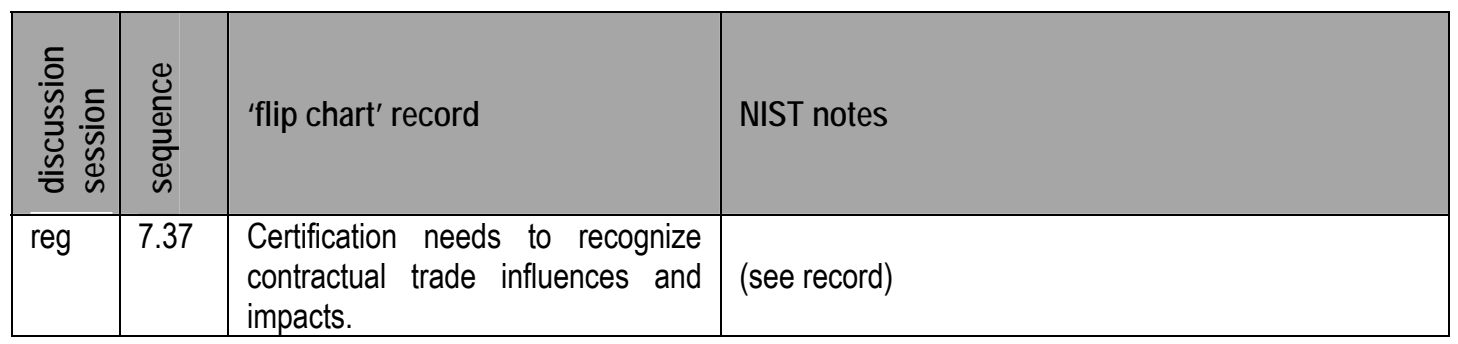


- Segmentation: MF/SF, new/existing, low-income/high-income

\begin{tabular}{|c|c|c|c|}
\hline 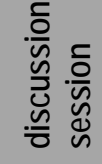 & 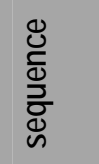 & 'flip chart' record & NIST notes \\
\hline comp & 3.06 & $\begin{array}{l}\text { SF decision-making much different } \\
\text { than MF, which involves } 3^{\text {rd }} \text { party } \\
\text { concerns. We have not presented } \\
\text { decision-makers with policy } \\
\text { impacts. }\end{array}$ & $\begin{array}{l}\text { Because there is political accountability, we should not } \\
\text { expect a change in the regulatory environment. The } \\
\text { distinction between single-family and multi-family is } \\
\text { important. Some standards, however, are decided not } \\
\text { at the policy level, but at the technical level, such as } \\
\text { codes. In the future, there is a need to provide } \\
\text { policymakers with choices about performance } \\
\text { standards and options about the minimums in the } \\
\text { codes. }\end{array}$ \\
\hline comp & 3.361 & (see notes) & $\begin{array}{l}\text { This is another difference between single-family and } \\
\text { multi-family housing. With multi-family, inspection is } \\
\text { considered due diligence. }\end{array}$ \\
\hline
\end{tabular}

- Value: cost, price, benefit

\begin{tabular}{|c|c|c|c|}
\hline 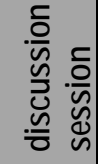 & 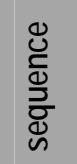 & 'flip chart' record & NIST notes \\
\hline cert & 4.41 & (see notes) & EAFs reduced quality. \\
\hline cert & 4.42 & (see notes) & $\begin{array}{l}\text { The problem with EAFs is that it was misapplied. It } \\
\text { came from Europe and was used in the U.S. without } \\
\text { good understanding of how it should be used here. }\end{array}$ \\
\hline
\end{tabular}




\section{Appendix C Schematic Durability Rating System and Valuation}

The relationship of durability to housing affordability was a recurring theme in workshop discussions. A builder stakeholder outlined one concept for development of a durability rating system that would project and value the residual durability of housing components and systems over time. The rating system is sketched in the following five diagrams. The first diagram suggests computation of total housing value as a combination of annualized inventory value, maintenance costs, operating costs, and durability rating parameters.

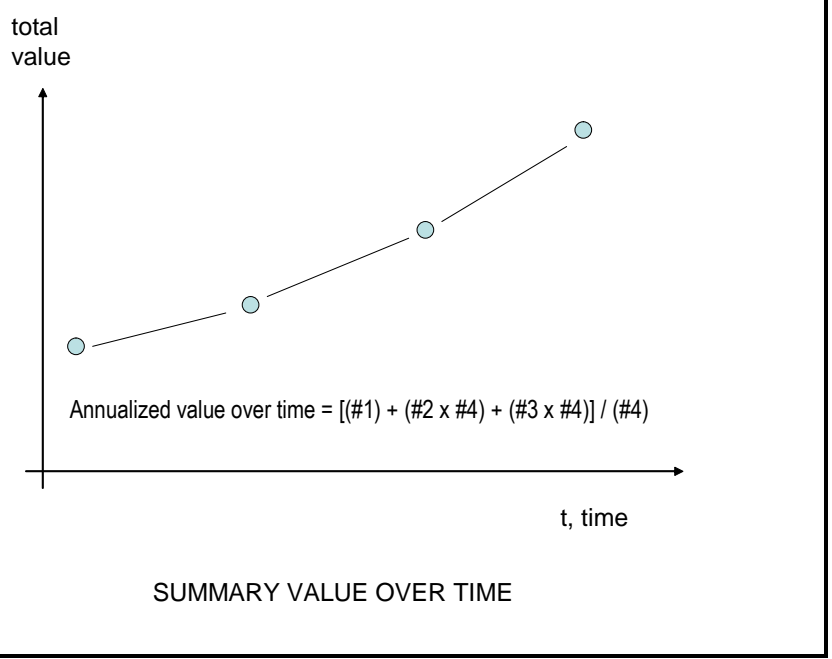

Parameter \#1, inventory value, would be determined for a base year and change as housing stock and average housing value fluctuated. Current rough estimates of 100 million units at an average value of $\$ 150000$ yields a $\$ 15$ trillion dollar housing stock value.

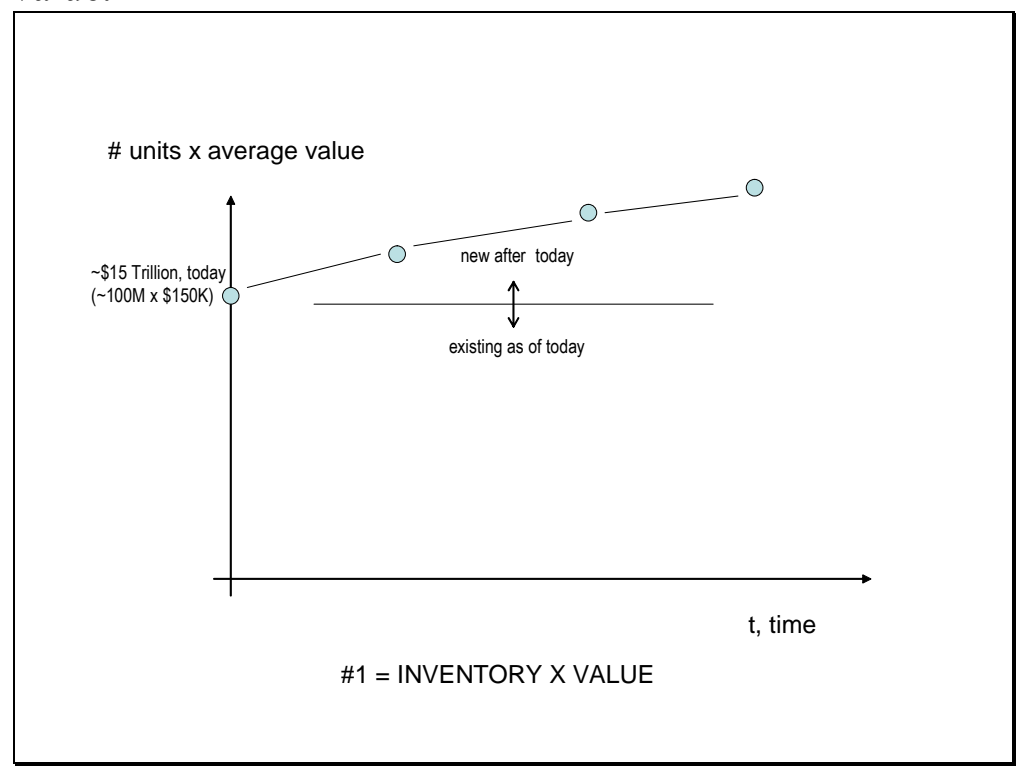


Parameter \#2, maintenance cost, would consist of expected annual upkeep punctuated by periodic component replacement. In the diagram, anticipated cumulative maintenance cost is expressed as a percentage of average housing value.

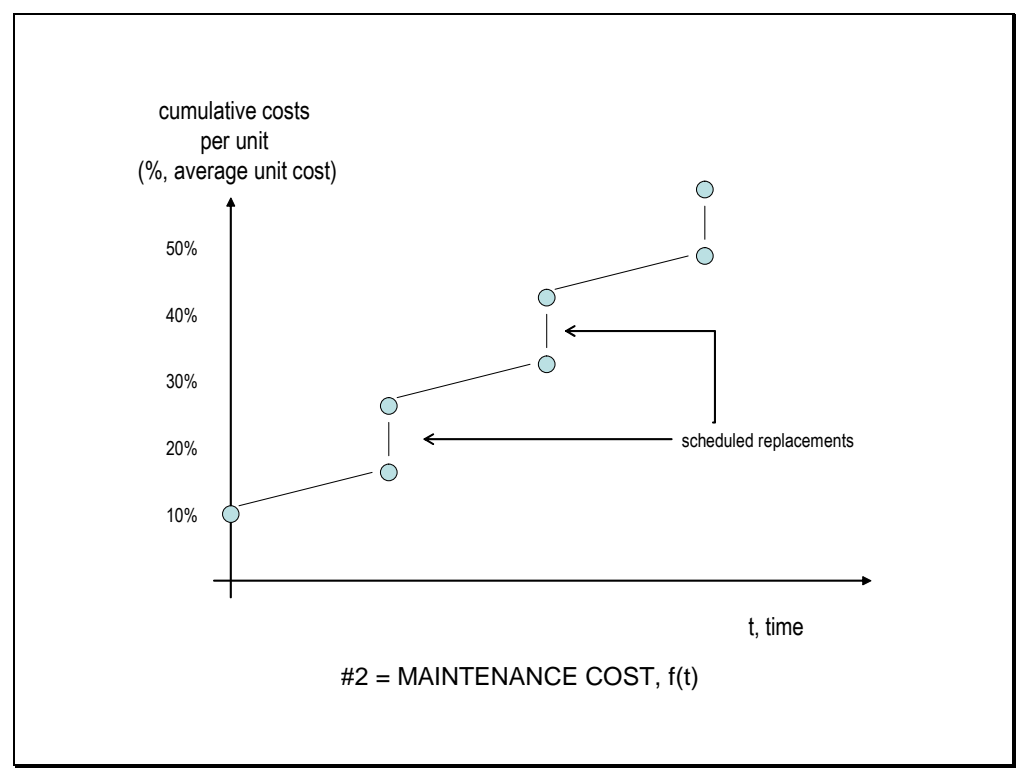

Parameter \#3, operating cost, would consist primarily of the expected consumption and prices of energy and utilities. Annual operating cost could be expanded to include other expenses, such as communications and insurance.

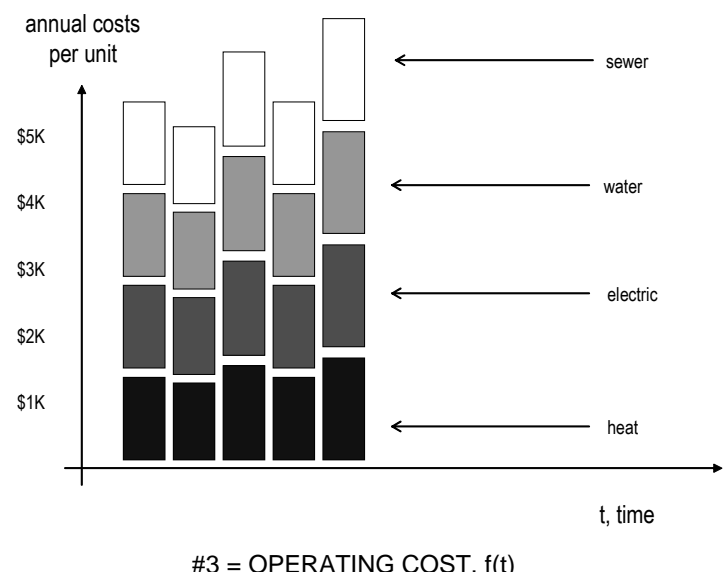


Parameter \#4, the durability rating, would be the key element of the system. The rating could, perhaps, value the number of years of relatively 'maintenance-free' operation that could be expected given the present condition of a property. Objectives could be set to increase the rating over time, while deferred maintenance could be expected to decrease the rating.

More timely maintenance can improve the durability of a structure. Extending the longevity of a structure reduces its annualized first cost of construction because it is spread out over a greater number of years.

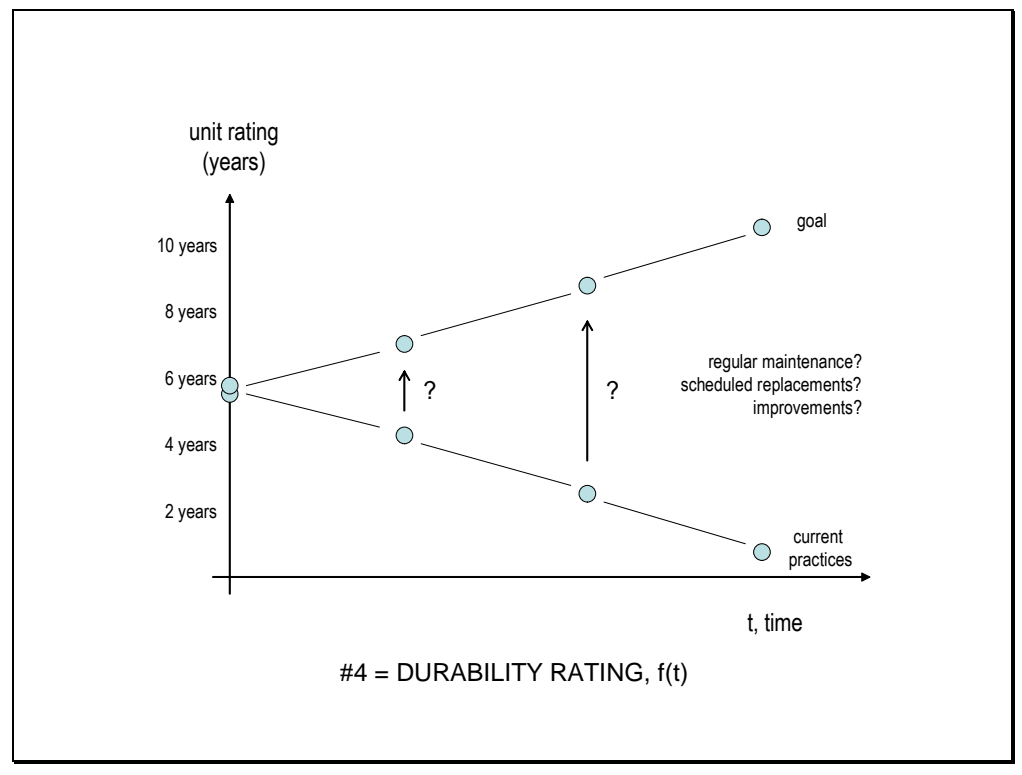




\title{
Appendix D Workshop Agenda
}

\author{
MEASURING AND ASSESSING THE CONSEQUENCES OF TECHNOLOGY AND \\ INNOVATION FOR AFFORDABILITY OF HOUSING \\ June 4-5, 2003, NIST North, Lecture Room 152
}

\section{AGENDA}

Wednesday, June 4, 2003

9:00 am Welcome and Introductions Jack Snell, NIST, and Carlos Martín, HUD

9:15 Historic Federal Role in Housing Affordability Carlos E. Martín

9:30 Affordability Guidelines and Workshop Objectives Robert Chapman, NIST

9:45 Discussion session* \#1: Who benefits from the housing innovation, both at component scale and at the scale of the entire house and its delivery system? Do the homebuyers or homeowners benefit? If there is a benefit of reduced first cost, does it pass through to the homeowner, or does it go into the pocket of someone in the supply chain of the current delivery system?

Leads: Richard Wright and Carlos Martín

10:45 Break

11:00 Discussion session \#3: How does each stakeholder view and compute lifecycle costs and benefits compared to first costs, at both scales?

Leads: Robert Chapman and Paul Emrath

12:00 Lunch

1:00pm Discussion session \#4: How does each stakeholder view and compute future benefits that are uncertain or contingent on very low probability events, such as protection from earthquakes or hurricanes that may never happen, at both scales? What happens when you add uncertainty to the costs and benefits discussed in session \#3? Leads: Ed Sutton and Robert Chapman

2:00 Discussion session \#5: How should the uncertainty and risk associated with using new versus traditional technology be addressed, at both scales?

Leads: Theresa Weston and Michelle McDonough

3:00 Break

3:30 Discussion session \#2: How to "push" innovation benefits to the homeowner, at the scale of housing components? How can we help the homebuyer to see the big picture, e.g., benefits as well as costs, especially initial costs? If a benefit comes at added cost, can the homeowner trade it off against reduced performance somewhere else in the house? Is the production function 
of housing (the current delivery system) flexible in that way to allow for substitutions among component costs, or is every innovation an "extra expense"? Leads: Ed Sutton and Theresa Weston

4:30 Recess

Thursday, June 5, 2003

8:30am Reconvene

8:45 Discussion session \#6: How should society value or monetize the social costs and benefits of introducing technology in residential housing, such as energy conservation or disaster relief and recovery, at both scales? What happens when you add social costs and benefits to the discussion?

Leads: Ron Piester and Michelle McDonough

9:45 Discussion session \#7: Can the regulatory system be used to encourage innovation, and to distinguish innovations with net benefits from those with net costs, at both component scale and at the scale of the entire house and its delivery system?

Leads: David Conover and John Hall

10:45 Break

11:00 Discussion session \#8: Who should bear the costs of development of new delivery systems and new infrastructure systems that are needed for innovation to penetrate the market at the scale of the entire house and its delivery system?

Leads: Paul Emrath and Theresa Weston

12:00 Lunch

1:00pm Affordability Guidelines Roadmap: Summary recommendations from each discussion session; roadmap for affordability guideline development.

Leads: Robert Chapman and David Engel

2:45 Closing Remarks: Next Steps Robert Chapman and David Engel

3:00 Adjourn

(*Each discussion session will be led by two individuals who will briefly set the stage $(\approx 10 \mathrm{~min})$ of possible positions; followed by facilitated discussion of subordinate questions among the full group ( $\approx 45 \mathrm{~min})$; and a $5 \mathrm{~min}$ summary of recommendations. Leads will be asked to pose divergent initial positions, as possible. Leads and/or facilitators will ensure that relationships to affordability guidelines roadmap development are considered as part of the discussion and recommendations. ) 


\section{Appendix EList of Attendees}

('Affordability in Housing' Discussion Leads)

\author{
PATRICIA H. ADKINS \\ Home Safety Council \\ 1725 Eye Street, NW, Suite 300 \\ Washington, DC 20006 \\ 202-349 1100 \\ patricia.adkins@homesafetycouncil.org
}

WILLIAM ASDAL

Asdal Builders

76 Rt. 24

Chester, NJ 07930

908-879-4427

asdal@rcn.com

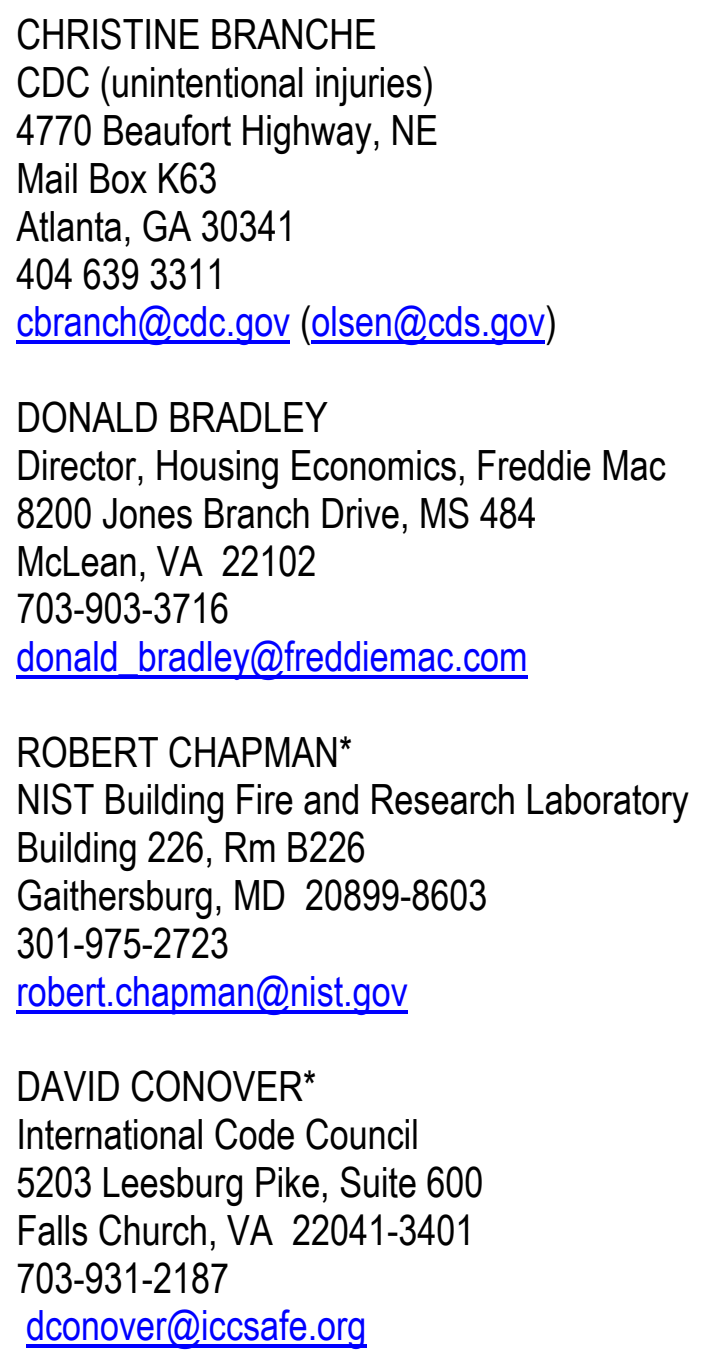

CHRISTINE BRANCHE

$\mathrm{CDC}$ (unintentional injuries)

4770 Beaufort Highway, NE

Mail Box K63

Atlanta, GA 30341

4046393311

cbranch@cdc.gov (olsen@cds.gov)

DONALD BRADLEY

Director, Housing Economics, Freddie Mac

8200 Jones Branch Drive, MS 484

McLean, VA 22102

703-903-3716

donald_bradley@freddiemac.com

ROBERT CHAPMAN*

NIST Building Fire and Research Laboratory

Building 226, Rm B226

Gaithersburg, MD 20899-8603

301-975-2723

robert.chapman@nist.gov

DAVID CONOVER*

International Code Council

5203 Leesburg Pike, Suite 600

Falls Church, VA 22041-3401

703-931-2187

dconover@iccsafe.org

\author{
DAVID DACQUISTO \\ Newport Partners LLC \\ 3760 Tanglewood Lane \\ Davidsonville, MD 21035 \\ 301.889.0017 \\ DavidDacquisto@NewportPartnersLLC.com
}

WILLIAM DUNCAN

Enterprise Foundation

10227 Wincopin Circle, Suite 500

Columbia, MD 21044

bduncan@ennterprisefoundation.org

PAUL EMRATH*

National Association of Homebuilders

1201 15th Street, NW

Washington, DC 20005

202-266-8449

pemrath@nahb.com

DAVID ENGEL*

HUD/Office of Policy Development and

Research

$4517^{\text {th }}$ Street, SW

Washington, DC 20410

202-708-4370

david.engel@hud.gov

NICK FARR

Executive Director

National Center for Healthy Housing

10227 Wincopin Circle

Columbia, MD 21044

ROBERT FULLER

NAHBRC

400 Prince Georges' Blvd.

Upper Marlboro, MD 20774

301-430-6216

bfuller@nahbrc.org 


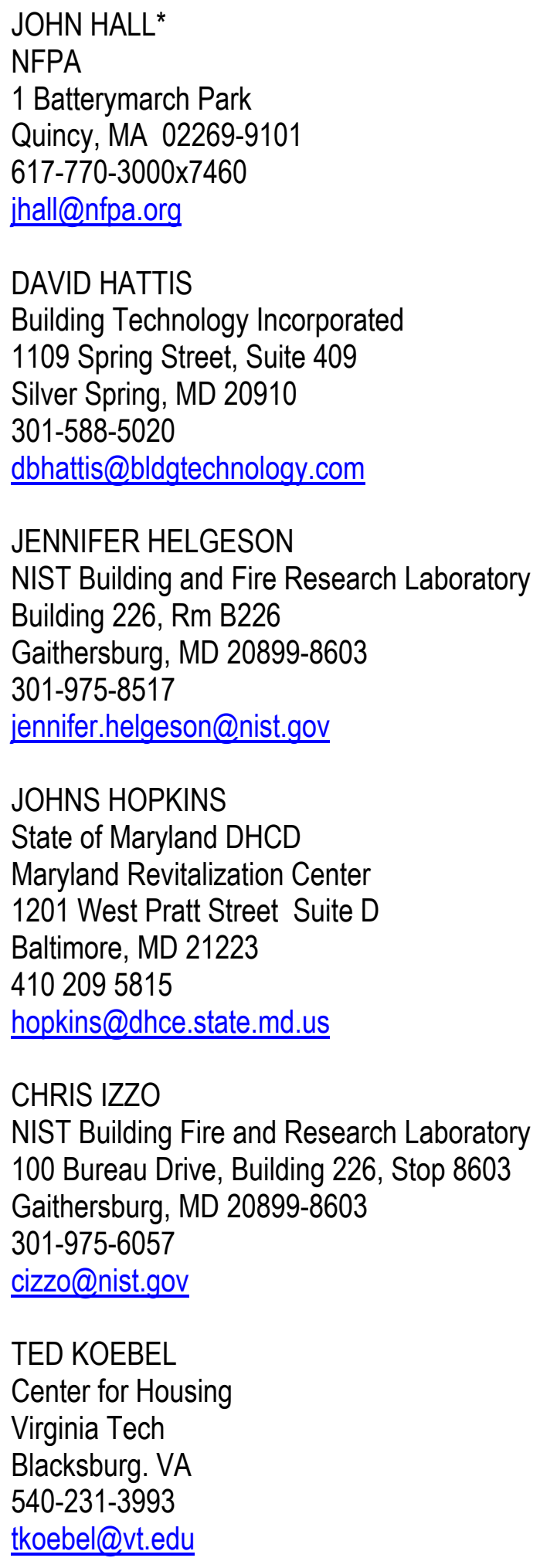

CHI LENG

NIST Building Fire and Research Laboratory 100 Bureau Drive, Building 226, Stop 8603

Gaithersburg, MD 20899-8603

301-975-4522

chi.leng@nist.gov

HAROLD MARSHALL

NIST Building Fire and Research Laboratory 100 Bureau Drive, Building 226, Stop 8603

Gaithersburg, MD 20899-8603

301-975-6131

harold.marshall@nist.gov

CARLOS MARTIN*

HUD/Office of Policy Development and

Research

$4517^{\text {th }}$ Street, SW

Washington, DC 20410

202-708-4370, x5726

carlos_e.martin@hud.gov

MICHELLE McDONOUGH*

FNMA

Policy Analyst

3900 Wisconsin Avenue, NW

Washington, DC 20016

202-752-3669

michelle_k_mcdonough@fanniemae.com

MAUREEN MCNULTY

D\&R International, Ltd.

1300 Spring Street, Suite 500

Silver Spring, MD 20910

301-588-9387

mmcnulty@drintl.com

RICARDO MERLO

HUD/Office of Policy Development and

Research

$4517^{\text {th }}$ Street, SW

Washington, DC 20410

202-708-0770, x5845

ricardo_I._merlo@hud.gov 


\author{
REBECCA MORLEY \\ Executive Director \\ National Center for Healthy Housing \\ 10227 Wincopin Circle \\ Columbia, MD 21044 \\ 410-772-2774 \\ rmorley@enterprisefoundation.org \\ RON PIESTER (for DOTTIE HARRIS)* \\ New York Department of State \\ 41 State Street \\ Albany, NY 12231 \\ 518-474-4073 (518-486-9888) \\ rpiester@dos.state.ny.us \\ (dharris@dos.state.ny.us ) \\ ANDY SCHOLZ \\ Genesis Homes \\ 2701 Cambridge Court, Suite 220 \\ Auburn Hills, MI 48326 \\ 248-276-1459 \\ ascholz@genesishomes.com
}

RON NICKSON

$\mathrm{NMHC}$

1850 M Street, NW, Suite 450

Washington, DC 20036

202-979-2327

rnickson@nmhc.org

JACK SNELL

NIST Building and Fire Research Laboratory

Building 226, Rm B216

Gaithersburg, MD 20899-8600

301-975-6850

jack.snell@nist.gov

BARRY STEFFEN

HUD/Office of Policy Development and

Research

451 7th St. SW, Room 8110

Washington, DC 20410-6000

202-708-1537 x5926

barry I._steffen@hud.gov
EDGAR SUTTON*

National Association of Homebuilders

1201 15th Street, NW

Washington, DC 20005

202-266-xxxx

esutton@nahb.com

JON TRAW

Traw Associates Consulting

14435 Eastridge Drive

Whittier, CA 90602-2745

562-789-7583

trawassoc@hotmail.com

THERESA WESTON*

DuPont Nonwovens, Spruance Plant

P.O. Box 27001

Richmond, VA 23261

804 383-4031

fax 804 383-3109

theresa.a.weston@usa.dupont.com

WILLIAM WHIDDON

Building Technology Incorporated

1109 Spring Street, Suite 409

Silver Spring, MD 20910

301-588-5020

wwhiddon@bldgtechnology.com

RICHARD WRIGHT*

20081 Doolittle Street

Montgomery Village, MD 20886-1354

3019779049

Fax: 3019631809

dickwrig@erols.com

ZOPHIA ZAGER

Director, Office of Building Code Services

County of Fairfax Virginia, 12055

Government Center Parkway

Fairfax, VA 22035-5504

703-324-1980

szager@fairfaxcounty.gov 